\title{
Two Long-Term Instrumental Climatic Data Bases of the People's Republic of China
}

\section{Contributed by}

Tao Shiyan, Fu Congbin, Zeng Zhaomei, Zhang Qingyun

Institute of Atmospheric Physics

Chinese Academy of Sciences

Beijing, China

Prepared by D. P. Kaiser

Carbon Dioxide Information Analysis Center

Oak Ridge National Laboratory

Oak Ridge. Tennessee, U.S.A.

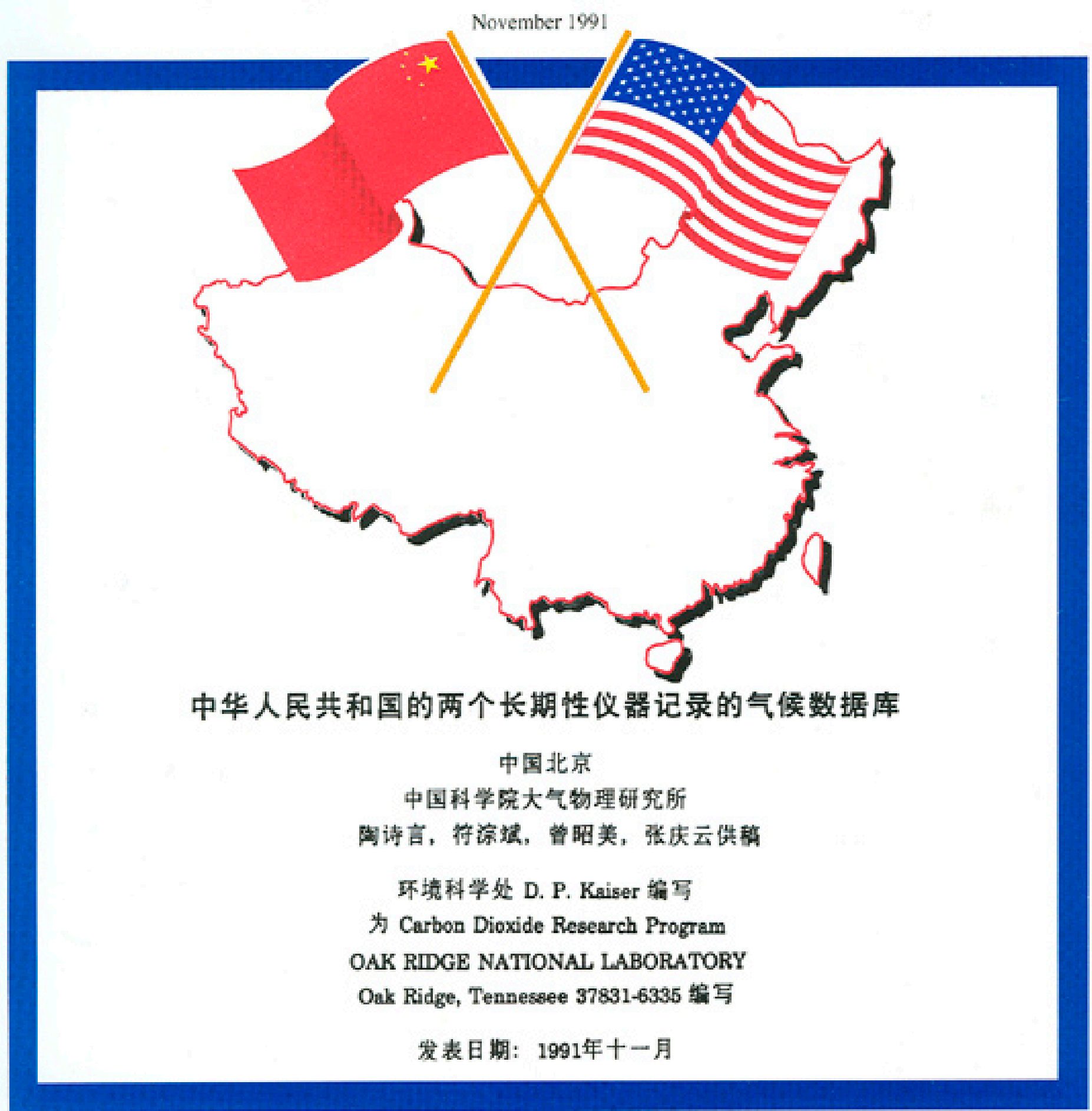


This report has been reproduced directly from the best available copy.

Available to DOE and DOE contractors from the Office of Scientific and Technical Information, P.O. Box 62, Oak Ridge, TN 37831; prices available from (615) 576-8401, FTS 626-8401.

Available to the public from the National Technical Information Service, U.S. Depertment of Commerce, 5285 Port Royal Rd., Springfield, VA 22161.

This report was prepared as an account of work sponsored by an agency of the United States Government. Neither the United States Government nor any agency thereof, nor any of their employees, makes any warranty, express or implied, or assumes any legal liability or responsibility for the accuracy, completeness, or usefulness of any information, apparatus, product, or process disclosed, or represents that its use would not infringe privately owned rights. Reference herein to any specific commercial product, process, or service by trade name, trademark, manufacturer, or otherwise, does not necessarily constitute or imply its endorsement, recommendation, or favoring by the United States Government or any agency thereof. The views and opinions of authors expressed herein do not necessarily state or reflect those of the United States Government or any agency thereof. 


\title{
TWO LONG-TERM INSTRUMENTAL CLIMATIC DATA BASES OF THE PEOPLE'S REPUBLIC OF CHINA
}

\author{
Contributed by \\ Tao Shiyan, Fu Congbin, Zeng Zhaomei, Zhang Qingyun \\ Institute of Atmospheric Physics \\ Chinese Academy of Sciences \\ Beijing, China
}

\author{
Prepared by D. P. Kaiser
}

Environmental Sciences Division

Publication No. 3747

Date Published: November 1991

Prepared for the

Carbon Dioxide Research Program

Environmental Sciences Division

Office of Health and Environmental Research

U.S. Department of Energy

Budget Activity Number KP 0500000

Prepared by the

Carbon Dioxide Information Analysis Center

OAK RIDGE NATIONAL LABORATORY

Oak Ridge, Tennessee 37831-6335 managed by

MARTIN MARIETTA ENERGY SYSTEMS, INC.

for the

U.S. DEPARTMENT OF ENERGY

under contract DE-AC05-84OR21400 


\title{
中华人民共和国的两个长期性仪器记录的气候数据库
}

\author{
中国北京 \\ 中国科学院大气物理研究所
}

陶诗言, 符淙斌, 曾昭美, 张庆云供稿

\author{
环境科学处 D. P. Kaiser 编写 \\ 文件编号 3747
}

发表日期：1991年十一月

发表日期：1991年十二月

发表日期：1992年一月

发表日期：1992年二月

为 Carbon Dioxide Research Program

Environmental Sciences Division

Office of Health and Environmental Research

U.S. Department of Energy 编写

(Budget Activity Number KP 050000 0)

OAK RIDGE NATIONAL LABORATORY

Oak Ridge, Tennessee 37831-6335 编写

MARTIN MARIETTA ENERGY SYSTEMS, INC. 为

美国能源部管理

(契约DE-AC05-84OR21400) 

TABLE OF CONTENTS

$\underline{\text { Page }}$

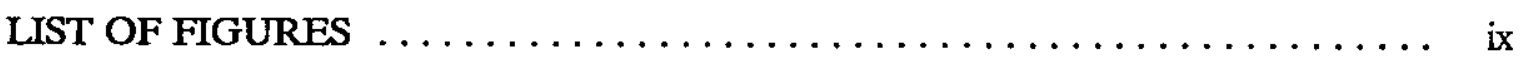

LIST OF TABLES $\ldots \ldots \ldots \ldots \ldots \ldots \ldots \ldots \ldots \ldots \ldots \ldots \ldots \ldots \ldots \ldots \ldots \ldots$

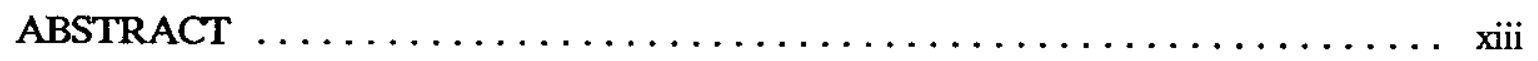

PART 1: INFORMATION ABOUT THE DATA PACKAGE $\ldots \ldots \ldots \ldots \ldots, 1$

1. NAME OF THE NUMERIC DATA PACKAGE $\ldots \ldots \ldots \ldots \ldots \ldots \ldots$

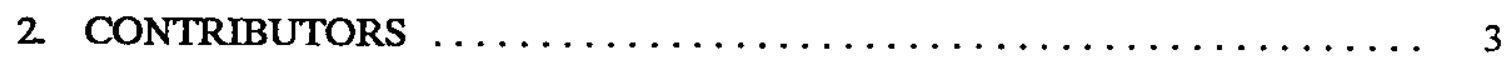

3. KEYWORDS $\ldots \ldots \ldots \ldots \ldots \ldots \ldots \ldots \ldots \ldots \ldots \ldots \ldots \ldots \ldots \ldots \ldots \ldots \ldots \ldots \ldots$

4. BACKGROUND INFORMATION $\ldots \ldots \ldots \ldots \ldots \ldots \ldots \ldots \ldots \ldots \ldots$

5. SOURCE AND SCOPE OF THE DATA $\ldots \ldots \ldots \ldots \ldots \ldots \ldots \ldots$

6. APPLICATIONS OF THE DATA $\ldots \ldots \ldots \ldots \ldots \ldots \ldots \ldots \ldots \ldots \ldots \ldots \ldots$

7. LIMTTATIONS AND RESTRICTIONS $\ldots \ldots \ldots \ldots \ldots \ldots \ldots \ldots \ldots$

8. QUALITY ASSURANCE OF THE PRC CLIMATE DATA BASES ...... 42

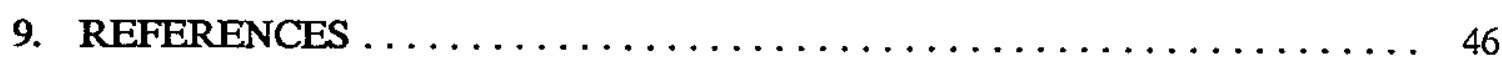

10. HOW TO OBTAIN THE DATA PACKAGE $\ldots \ldots \ldots \ldots \ldots \ldots \ldots, 48$

PART 2: INFORMATION ABOUT THE MAGNETIC TAPE $\ldots \ldots \ldots \ldots \ldots 49$

11. CONTENTS OF THE MAGNETIC TAPE $\ldots \ldots \ldots \ldots \ldots \ldots \ldots \ldots \ldots$

12. DESCRIPTIVE FILE ON THE MAGNETIC TAPE $\ldots \ldots \ldots \ldots \ldots \ldots 53$

13. LISTINGS OF THE FORTRAN IV DATA RETRIEVAL PROGRAMS . . . 67

14. LISTINGS OF THE SAS* INPUT/OUTPUT RETRIEVAL PROGRAMS . . . 72 "SAS is a registered trademark of SAS Institute, Inc., Cary, North Carolina 27511-8000. 
15. VERIFICATION OF DATA TRANSPORT

APPENDICES

APPENDIX A: INSTRUMENTATION AND DATA COLLECTION

METHODS OF STATIONS IN THE PRC

60-STATION CLIMATE NETWORK

APPENDIX B: STATION HISTORIES OF THE PRC 60-STATION

CLIMATE NETWORK . . . . . . . . . . . . . . B-1

APPENDIX C: SOURCES OF DATA FOR THE PRC 60-STATION

CLIMATE DATA SET $\ldots \ldots \ldots \ldots \ldots \ldots \ldots \ldots \ldots$ C-1

APPENDIX D: $\quad$ REPRINTS OF PERTINENT LITERATURE . . . . . . . D

Urban Heat Islands in China. by W.-C. Wang, Z. M. Zeng,

and T. R. Karl 1990......................... D-3 


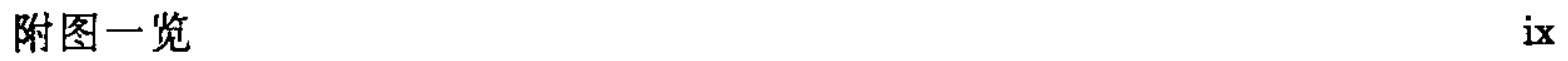

附表一览管

提要 $\quad x v$

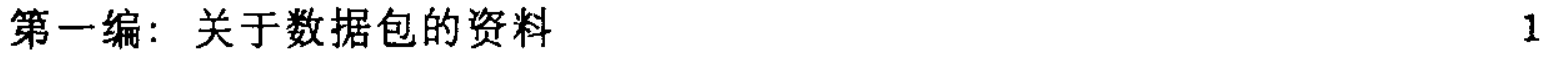

1. 数字数据包的名称 3

2. 供稿者 3

3. 关键词 3

4. 背景资料 3

5. 数据的来源和范围 6

6. 数据的应用 41

7. 局限与限制利 41

8. 中华人民共和国气候数据库的质量保证 42

9. 参考文献 46

10. 如何取得这个数据包 48

第二编：关于磁带的资料 49

11. 磁带记录的内容 51

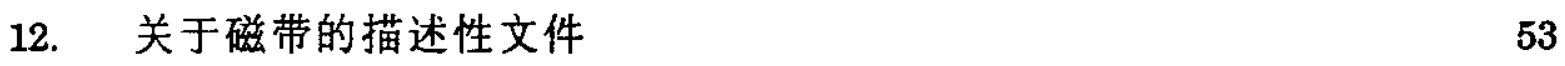

13. Fortran IV 数据检索程序一览表 67

14. SAS ${ }^{\mathrm{TM}}$ 输人与输出检索程序一览表 72

15. 数据传输的核查 77

附录:

附录一：中华人民共和国60台气候网络中各台的仪器设备与搜集数据的方法

附录二：中华人民共和国60台气候网络中各台的历史 B-1

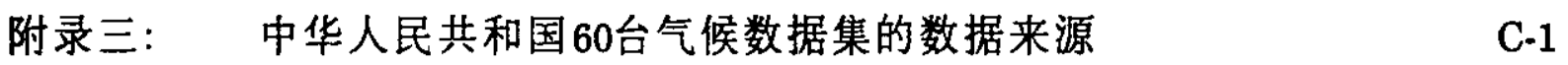

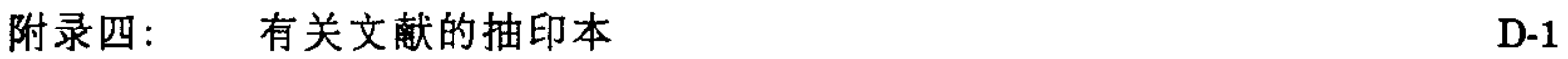

Urban Heat Islands in China (中国的城市热岛) W.-C. Wang, Zhaomei Zeng, and T. R. Karl. 1990.

D-3 


\section{LIST OF FIGURES}

Figure

$\underline{\text { Page }}$

1. Percentage (a) and cumulative percentage (b) of stations from the PRC 60-station climate network with given record lengths

2. Number of stations in the PRC 60-station climate network with data for each year over the period 1841-1988

3. Distribution of stations from the PRC 60-station climate data

4. Distribution of stations from the PRC 60 -station climate data set as of 1900 .

5. Distribution of stations from the PRC 60 -station climate data set as of 1920

6. Distribution of stations from the PRC 60-station climate data set as of 1940

7. Distribution of stations from the PRC 60-station climate data set over the period 1951-1988

8. Distribution of stations from the PRC 60 -station climate data set which have data for 1945

9. Percentage (a) and cumulative percentage (b) of stations from the PRC 205-station temperature data set with given record lengths

10. Percentage (a) and cumulative percentage (b) of stations from the PRC 205-station precipitation data set with given record lengths

11. Number of stations in the PRC 205-station climate network with data for each year over the period 1880-1988

12. Distribution of stations from the PRC 205-station precipitation data set as of 1900

13. Distribution of stations from the PRC 205-station temperature data set as of 1920

14. Distribution of stations from the PRC 205-station precipitation data set as of 1920 
15. Distribution of stations from the PRC 205-station temperature data set as of 1940

16. Distribution of stations from the PRC 205-station precipitation data set as of 1940

17. Distribution of stations from the PRC 205-station temperature and precipitation data sets as of 1961

18. Distribution of stations from the PRC 205-station temperature data set which have data for 1945

19. Distribution of stations from the PRC 205 -station precipitation data set which have data for 1945 


\section{LIST OF TABLES}

$\underline{\text { Table }}$

Page

1. Instrumental and proxy data sets compiled to date under the DOE/PRC collaborative research program $\ldots \ldots \ldots \ldots \ldots \ldots \ldots \ldots$

2. Sample listing of the PRC 60 -station climate data set $\ldots \ldots \ldots \ldots \ldots$

3. Inventory of stations in the PRC 60 -station climate network $\ldots \ldots \ldots \ldots \ldots$

4. Gaps in the periods of record of stations in the PRC

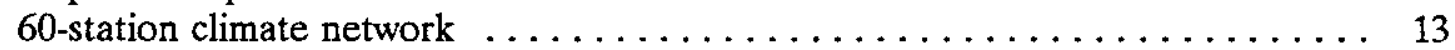

5. Sample listing of the PRC 205-station monthly mean

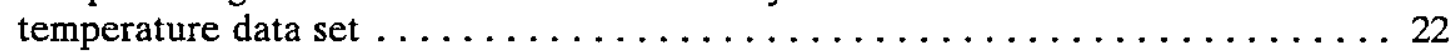

6. Sample listing of the PRC 205-station monthly total

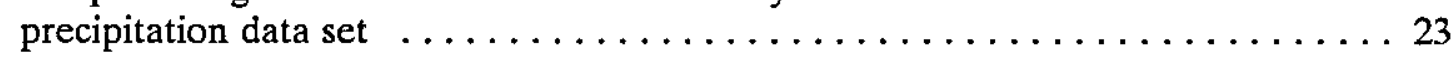

7. Inventory of stations in the PRC 205-station temperature

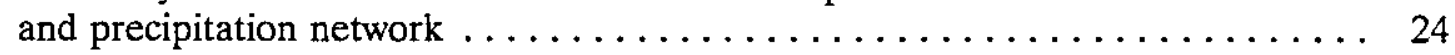

8. Characteristics of numeric variables from the 60 -station

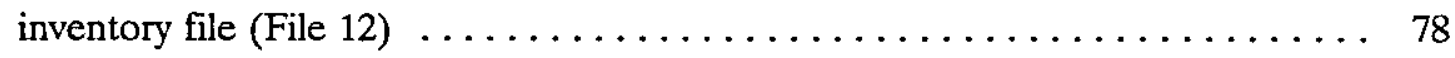

9. Characteristics of numeric variables from the 205 station inventory file (File 13)

10. Characteristics of numeric variables from the 60 -station climate data file (File 14)

11. Characteristics of numeric variables from the 205 station monthly mean temperature file (File 15)

12. Characteristics of numeric variables from the 205 station monthly total precipitation file (File 16) 


\begin{abstract}
TAO SHIYAN, FU CONGBIN, ZENG ZHAOMEI, and ZHANG QINGYUN. 1991. Two long-term instrumental climatic data bases of the People's Republic of China. ORNL/CDIAC-47, NDP-039. Carbon Dioxide Information Analysis Center, Oak Ridge National Laboratory, Oak Ridge, Tennessee. 198 pp. doi: 10.3334/CDIAC/cli.ndp039
\end{abstract}

Two long-term instrumental data bases containing meteorological observations from the People's Republic of China (PRC) are described. These data sets were compiled in accordance with a joint research agreement signed by the United States Department of Energy (DOE) and the PRC Chinese Academy of Sciences (CAS) on August 19, 1987. CAS has provided records from 265 stations, partitioned into networks of 60 and 205 stations which each provide good geographical coverage of the PRC. The 60-station network data contain monthly measurements of barometric pressure, air temperature, precipitation amount, relative humidity, sunshine duration, cloud amount, wind direction and speed, and number of days with snow cover. Detailed station histories are presented for all 60 stations. The 205-station network data contain monthly mean temperatures and monthly precipitation totals; however, station histories are not currently available. Sixteen stations from these data sets ( 13 from the 60 -station, 3 from the 205 -station) have temperature and/or precipitation records which begin prior to 1900 , whereas the remaining stations began observing in the early to mid 1900s. Records from 262 stations extend through 1988; the remaining three station records extend through the early 1980 s.

These data can be used in defining regional climate changes, establishing relationships between regional and large-scale climates, and in studying the climatic impacts of urbanization and increased concentrations of greenhouse gases. Additional uses could include examining impacts of periodic events such as volcanic eruptions or the El Niño/Southern Oscillation (ENSO). These data sets represent the most comprehensive, long-term instrumental Chinese climate data presently available. 



\section{提要}

陶诗言, 符淙斌, 曾昭美, 张庆云. 1991 .

Two Long-Term Instrumental Climatic Data Bases of the People's Republic of China (中华人民共和国的两个长期性仪器记录的气候数 据库). Carbon Dioxide Information Analysis Center, Oak Ridge National Laboratory, Oak Ridge, Tennessee. 198pp.

本文描述的内容为中华人民共和国气象观测资料的两个长期性仪器记录 的气候数据库。这些数据集是按照美国能源部 (DOE) 与中华人民共和国中国科 学院 (CAS) 于 1987年八月十九日签署的联合研究协定而编辑的。中国科学院提 供了 265 个气象台的观测记录。265个气象台分为两个网络; 其一有 60 台, 其二 有 205 台。每一网络均能在地理上很好地涵盖中国。来自 60 台网络的数据, 包括 气压、气温、降雨量、相对湿度、日光量和云量, 风向与风速, 积雪天数等参 数的每月平均值、极端值或总值。205台网络的数据, 包括每月平均温度和每月 总降雨量, 其各台台史目前暂缺。这些数据集里的16个气象台（60台网络中的 13台和 205 台网络中的 3 台)，拥有 1900年以前即已开始的温度与 (或) 降雨量 记录, 而其余各台, 却是在 1900 年代的初叶至中叶才开始观测工作的。所有 265 台的观测记录, 均截至 1988年为止。

这些数据可用来确定地区气候的改变、确定地区气候与大范围气候之间 的关系, 并可用来研究气候对都市化和温室气体浓度增加的影响。另外的一些 用途, 可包括确定火山爆发或厄尼诺和南方涛动(ENSO)等周期性事件的影响。 这些数据集能提供目前可供使用的最全面的长期性仪器记录的中国气候数据。 

PART 1

INFORMATION ABOUT THE DATA PACKAGE 



\section{NAME OF THE NUMERIC DATA PACKAGE}

Two Long-Term Instrumental Climatic Data Bases of the People's Republic of China

\section{CONTRIBUTORS}

Tao Shiyan, Fu Congbin, Zeng Zhaomei, and Zhang Qingyun

Institute of Atmospheric Physics

Chinese Academy of Sciences

Beijing, China

\section{KEYWORDS}

Regional climate change; temperature; precipitation; relative humidity; sunshine duration; cloud amount; snow cover; dominant wind direction/frequency; wind speed.

\section{BACKGROUND INFORMATION}

The U.S. Department of Energy (DOE) and the People's Republic of China (PRC) Chinese Academy of Sciences (CAS) signed an agreement on August 19, 1987, to carry out a joint research program on possible $\mathrm{CO}_{2}$-induced climate changes. Concern over such climate changes stems from rising atmospheric concentrations of $\mathrm{CO}_{2}$ and other greenhouse gases, as well as the ever-increasing global $\mathrm{CO}_{2}$ emissions from fossil fuel use (Marland and Rotty 1984). The nature of these phenomena signals the need for international research efforts in the area of possible man-made climate change. The intent of the DOE/CAS research agreement is to contribute to research efforts through the performance of four tasks: (1) analysis of general circulation models (GCMs), (2) preparation and analysis of proxy and instrumental data, (3) study of the relationship between large and regional-scale climates, and (4) study of possible increases in atmospheric $\mathrm{CH}_{4}$ (Koomanoff et al. 1988). Descriptions of these tasks and additional background information on each country's involvement in atmospheric $\mathrm{CO}_{2}$ research may also be found in Koomanoff et al. (1988).

This package contains and describes two long-term PRC instrumental climate data bases, which were exchanged along with PRC proxy data sets and U.S. instrumental data sets according to the data exchange protocol contained in the DOE/CAS agreement. A descriptive list of the instrumental and proxy data sets compiled to date under the agreement is contained in Table 1 . This is essentially Table 1 from Koomanoff et al. (1988), containing many updates of data base specifics which have been derived from DOE analyses of these data sets performed since 1988. These data as a whole should be useful in defining regional climate changes, establishing relationships between regional and large-scale climates, and examining feedback processes during regional climate changes of selected case studies, such as wet and dry periods and desertification (Koomanoff et al. 1988). 


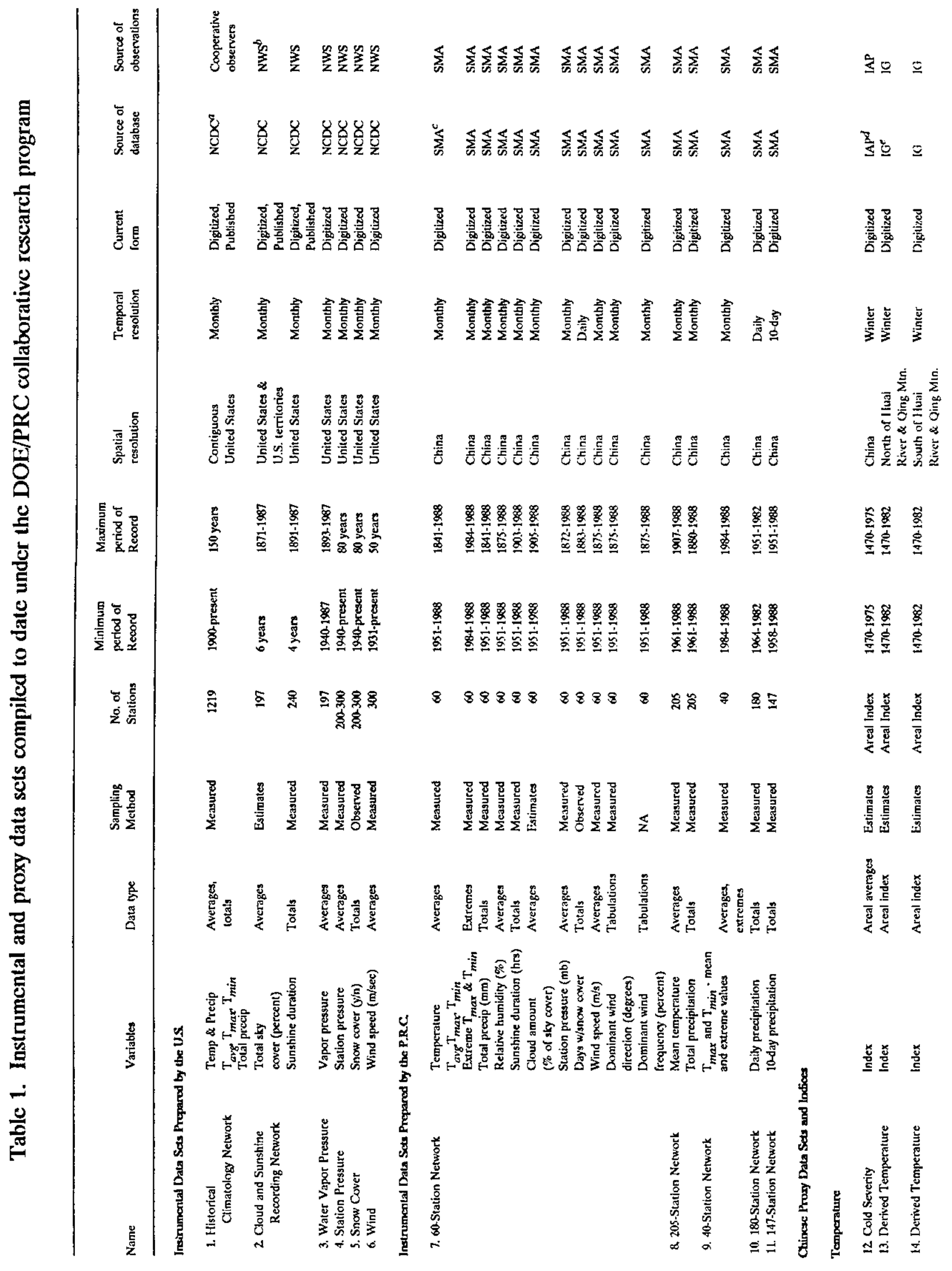


5

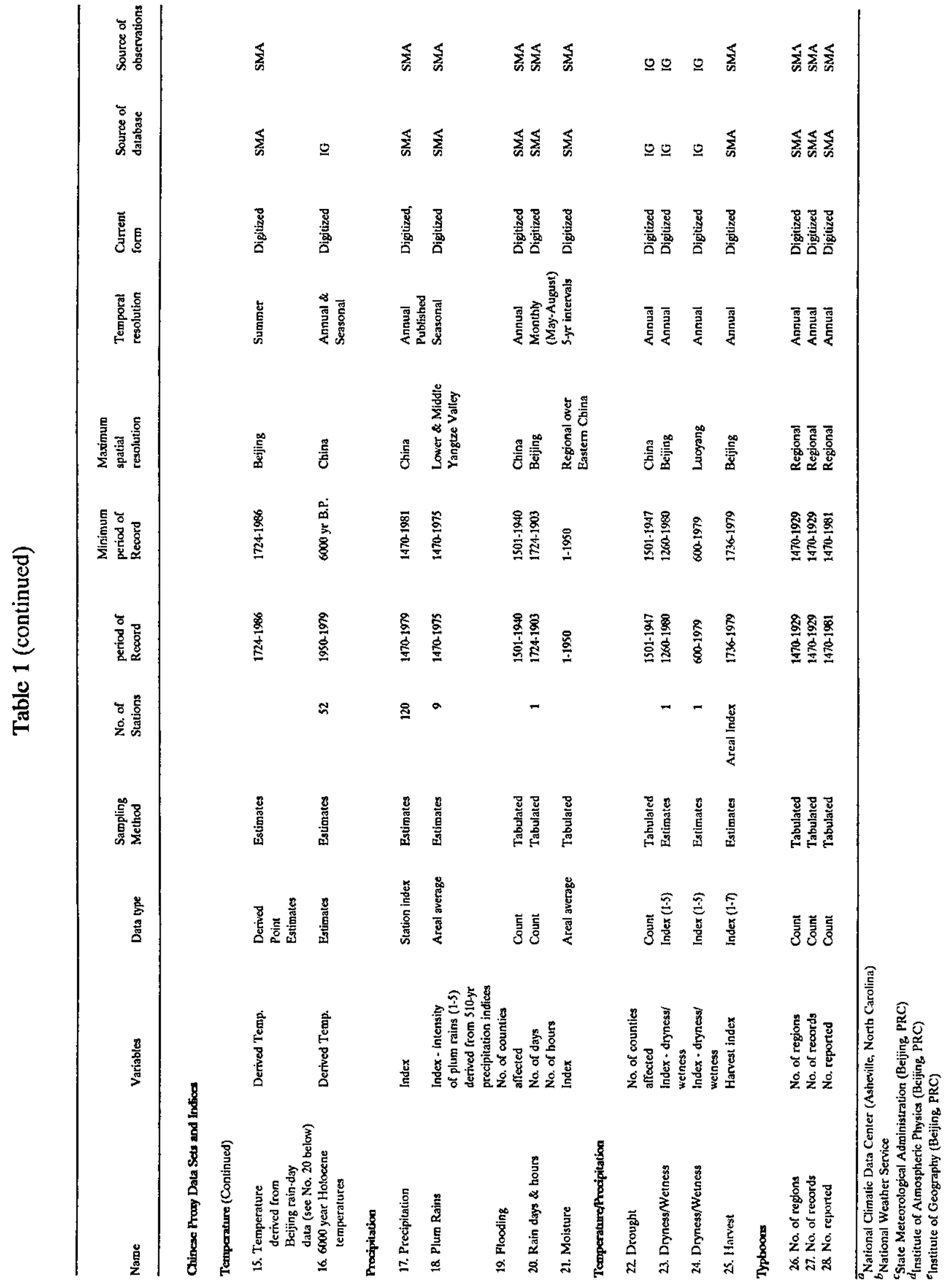


The PRC data sets contained in this package are comprised of observations from a 60-station network (Table 1, No. 7) and a 205-station network (Table 1, No. 8). These data sets contain monthly means, extremes, and totals of several important climatic variables. A subset of the monthly mean temperature data has already been used in assessing urban heat island effects in eastern China over the period 1954-1983 (Jones et al. 1990; Wang et al. 1990). The other types of data contained within will likely prove to be of similar practical value.

These data sets contain the most comprehensive, long-term instrumental Chinese climate data presently available. They may be used for comparison with the Chinese climate records published in the World Monthly Surface Station Climatology (Spangler and Jenne 1990), World Weather Records ${ }^{*}$, and records published by Jones et al. (1985), Bradley et al. (1985), and Eischeid et al. (1991). The spatial and temporal coverage offered by these 265 stations significantly improves upon that of other published sources.

\section{SOURCE AND SCOPE OF THE DATA}

Two PRC climate data bases, derived mainly from instrument measurements, are presented in this package; one consists of monthly means, extremes, or totals of 14 meteorological variables observed at 60 stations, the other contains monthly mean temperatures and monthly precipitation totals from 205 stations. The two data bases have no stations in common. Each is described in detail in the following sections.

\section{0-STATION NETWORK}

As previously noted, the data from the 60-station network consist of monthly means, extremes, or totals of the following 14 meteorological variables:

- Mean Station Pressure (mb)

- Mean Temperature $\left({ }^{\circ} \mathrm{C}\right)$

- Mean Maximum Temperature $\left({ }^{\circ} \mathrm{C}\right)$

- Mean Minimum Temperature $\left({ }^{\circ} \mathrm{C}\right)$

- Total Precipitation (mm)

- Sunshine Duration (hours)

- Mean Cloud Amount (percentage of sky cover)

- Mean Relative Humidity (percent)

- Snow Days (days with snow cover)

- Dominant Wind Direction (degrees)

- Mean Wind Speed $(\mathrm{m} / \mathrm{s})$

- Dominant Wind Frequency (percent)

- Extreme Maximum Temperature $\left({ }^{\circ} \mathrm{C}\right)$

- Extreme Minimum Temperature $\left({ }^{\circ} \mathrm{C}\right)$

"[Smithsonian Institution (1927, 1934, 1947); U.S. Weather Bureau (1959,1967); National Environmental Satellite, Data, and Information Service (1981-1983)] 
A sample listing of these data, illustrating the initial records contained in the 60-station data file included with this package, is presented in Table 2. Each record contains one month's data; the World Meteorological Organization (WMO) station number, year, and month, followed by the data variables in the same order as previously listed. Each data value is given in tenths of its specified unit of measure. Missing data values are indicated by "-9999".

Four basic criteria were used in selecting stations to make up the 60 -station network: (1) the station should be representative of a particular climate region of China, (2) the station's data should be of relatively high quality, (3) the period of record of the station should be reasonably long, and (4) the resulting station network should have a relatively uniform spatial distribution. An inventory of the selected stations is given in Table 3. Thirteen stations began observing before 1900; Beijing's record being the longest, with temperature and precipitation data dating back to 1841 . All 60 stations have temperature and/or precipitation data available from the beginning of their periods of record, with other types of observations beginning more randomly with time throughout the network. Records from all stations run through 1988 , but extreme maximum and minimum temperature data are available for each station only since 1984.

A better feel for the relative length of station records in this data set can be gained using Fig. 1, which shows the percentage and cumulative percentage of stations falling into specific ranges of record length. In the figure the length of station record refers to the number of years for which the station has at least partial data, which in most cases is less than the number of years since the station opened (Discontinuities in the records are the norm). Figure 1 indicates nearly one-half of the 60 stations have some type of data for at least 70 years, but only $10 \%$ have data for 100 years or more. Figure 2 shows the number of stations with data for each year over the period 1841-1988. The most notable feature of this graph is the reduction in the number of stations operating in the 1940s (centered on 1945 and assumably related to World War II and its aftermath). Figure 2 also shows that data are available from all 60 stations over the period 1951-1988. Periods of whole years with no data have been omitted from the data set and are detailed in Table 4.

Maps depicting the evolution of the 60-station network are shown in Figs. 3-7. They indicate the locations of stations which had been opened as of $1880,1900,1920$, 1940 , and 1951, respectively. However, each station shown does not necessarily have data for that particular year. Numbers plotted at station locations correspond to the station identification numbers at the left of Tables 3 and 4. Stations with data for 1945 (the leanest data year in the era of decreased coverage caused by World War II) are mapped in Fig. 8.

Details of data collection methods used at the 60 stations (e.g., type, orientation, and calibration of instruments; daily observing times; and observational techniques) have been made available by CAS and are contained in Appendix A. Station histories extending through 1983 are available for all 60 stations and are given in Appendix B. Some 161 official PRC sources were used in compiling the data set and are listed in Appendix C. 


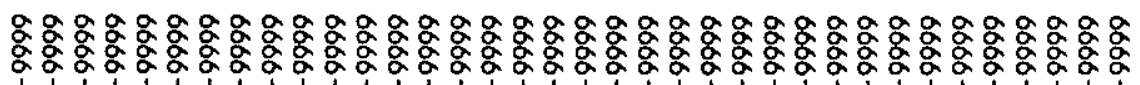

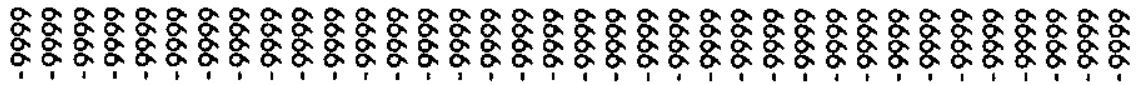

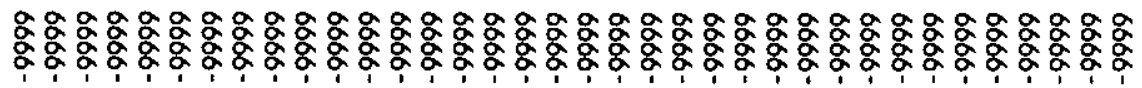

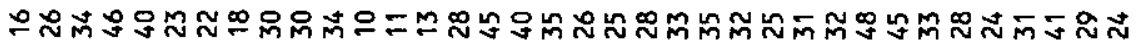

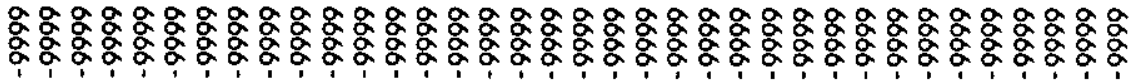

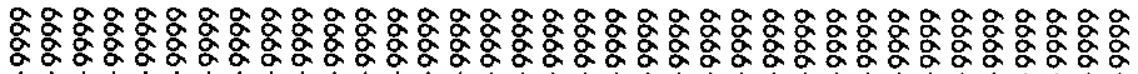

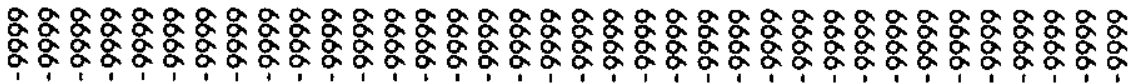

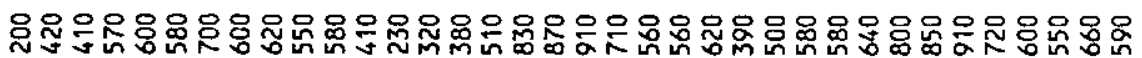

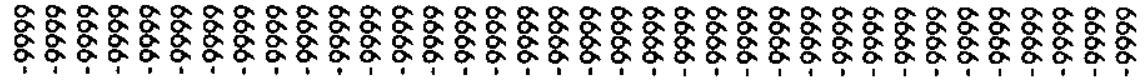

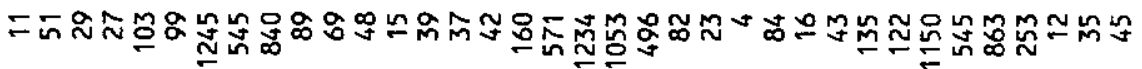

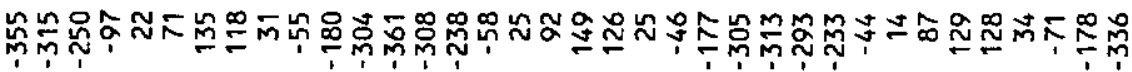

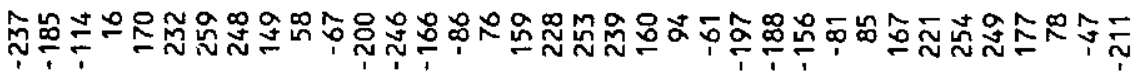

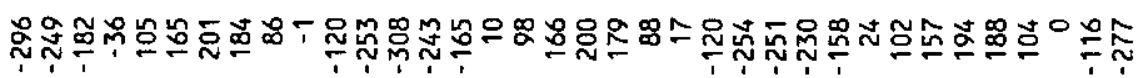

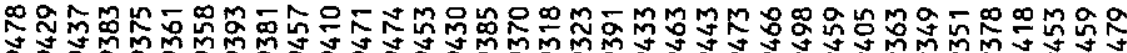

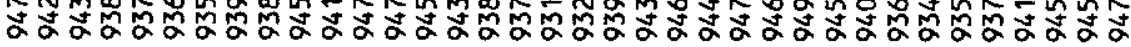

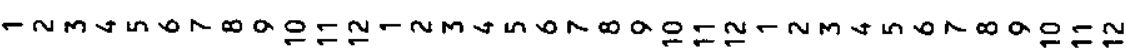

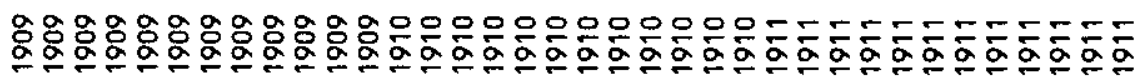

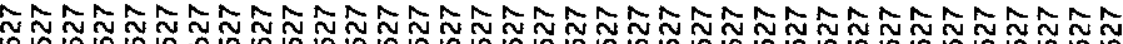

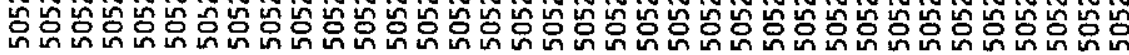


Table 3. Inventory of stations in the PRC 60-station climate network

\begin{tabular}{|c|c|c|c|c|c|c|}
\hline & Station name & $\begin{array}{l}\text { Station } \\
\text { number }\end{array}$ & Latitude $^{a}$ & Longitude $^{b}$ & Elevation (m) & $\begin{array}{l}\text { eginning of } \\
\text { period of } \\
\text { record }\end{array}$ \\
\hline 1 & Hailaer & 50527 & $49^{\circ} 13^{\prime}$ & $119^{\circ} 45^{\prime}$ & 612.8 & 1909 \\
\hline 2 & NenJiang & 50557 & $49^{\circ} 10^{\prime}$ & $125^{\circ} 14^{\prime}$ & 242.2 & 1939 \\
\hline 3 & BoKeTu & 50632 & $48^{\circ} 46^{\prime}$ & $121^{\circ} 55^{\prime}$ & 739.4 & 1914 \\
\hline 4 & QiQiHaEr & 50745 & $47^{\circ} 23^{\prime}$ & $123^{\circ} 55^{\prime}$ & 145.9 & 1930 \\
\hline 5 & HaErBin & 50953 & $45^{\circ} 41^{\prime}$ & $126^{\circ} 37^{\prime}$ & 171.7 & 1898 \\
\hline 6 & Yi Ning & 51431 & $43^{\circ} 57^{\prime}$ & $81^{\circ} 20^{\prime}$ & 662.5 & 1951 \\
\hline 7 & WuLuMuQi & 51463 & $43^{\circ} 47^{\prime}$ & $87^{\circ} 37^{\prime}$ & 917.9 & 1907 \\
\hline 8 & HaMi & 52203 & $42^{\circ} 49^{\prime}$ & $93^{\circ} 31^{\prime}$ & 737.9 & 1951 \\
\hline 9 & Jiu Quan & 52533 & $39^{\circ} 46^{\prime}$ & $98^{\circ} 31^{\prime}$ & 1477.2 & 1934 \\
\hline 10 & ZhangYe & 52652 & $38^{\circ} 56^{\prime}$ & $100^{\circ} 35^{\prime}$ & 1483.0 & 1937 \\
\hline 11 & XiNing & 52866 & $36^{\circ} 37^{\prime}$ & $101^{\circ} 46^{\prime}$ & 2261.2 & 1936 \\
\hline 12 & LanZhou & 52889 & $36^{\circ} 03^{\prime}$ & $103^{\circ} 53^{\prime}$ & 1517.2 & 1932 \\
\hline 13 & HuHeHaoTe & 53463 & $40^{\circ} 48^{\prime}$ & $111^{\circ} 38^{\prime}$ & 1063.0 & 1915 \\
\hline 14 & YinChuan & 53614 & $38^{\circ} 29^{\prime}$ & $106^{\circ} 13^{\prime}$ & 1111.5 & 1935 \\
\hline 15 & YuLin & 53646 & $38^{\circ} 14^{\prime}$ & $109^{\circ} 42^{\prime}$ & 1057.5 & 1933 \\
\hline 16 & TaiYuan & 53772 & $37^{\circ} 47^{\prime}$ & $112^{\circ} 33^{\prime}$ & 777.9 & 1916 \\
\hline 17 & MuDanJiang & 54094 & $44^{\circ} 34^{\prime}$ & $129^{\circ} 36^{\prime}$ & 241.4 & 1909 \\
\hline 18 & ChangChun & 54161 & $43^{\circ} 53^{\prime}$ & $125^{\circ} 20^{\prime}$ & 236.8 & 1909 \\
\hline 19 & ShenYang & 54342 & $41^{\circ} 46^{\prime}$ & $123^{\circ} 26^{\prime}$ & 41.6 & 1905 \\
\hline 20 & BeiJing & 54511 & $39^{\circ} 56^{\prime}$ & $116^{\circ} 17^{\prime}$ & 54.0 & 1841 \\
\hline 21 & TianJin & 54527 & $39^{\circ} 06^{\prime}$ & $117^{\circ} 10^{\prime}$ & 3.3 & 1900 \\
\hline 22 & BaoDing & 54602 & $38^{\circ} 50^{\prime}$ & $115^{\circ} 34^{\prime}$ & 17.2 & 1913 \\
\hline 23 & DaLian & 54662 & $38^{\circ} 54^{\prime}$ & $121^{\circ} 38^{\prime}$ & 92.8 & 1904 \\
\hline 24 & YanTai & 54765 & $37^{\circ} 32^{\prime}$ & $121^{\circ} 24^{\prime}$ & 46.7 & 1886 \\
\hline 25 & JiNan & 54823 & $36^{\circ} 41^{\prime}$ & $116^{\circ} 59^{\prime}$ & 51.6 & 1916 \\
\hline 26 & QingDao & 54857 & $36^{\circ} 04^{\prime}$ & $120^{\circ} 20^{\prime}$ & 76.0 & 1898 \\
\hline 27 & LaSa & 55591 & $29^{\circ} 42^{\prime}$ & $91^{\circ} 08^{\prime}$ & 3658.0 & 1935 \\
\hline 28 & ChengDu & 56294 & $30^{\circ} 40^{\prime}$ & $104^{\circ} 01^{\prime}$ & 506.1 & 1907 \\
\hline 29 & XiChang & 56571 & $27^{\circ} 54^{\prime}$ & $102^{\circ} 16^{\prime}$ & 1590.0 & 1924 \\
\hline 30 & TengChong & 56739 & $25^{\circ} 07^{\prime}$ & $98^{\circ} 29^{\prime}$ & 1647.8 & 1911 \\
\hline 31 & KunMing & 56778 & $25^{\circ} 01^{\prime}$ & $102^{\circ} 41^{\prime}$ & 1891.4 & 1901 \\
\hline 32 & TianShui & 57006 & $34^{\circ} 35^{\prime}$ & $105^{\circ} 45^{\prime}$ & 1131.7 & 1935 \\
\hline 33 & XiAn & 57036 & $34^{\circ} 18^{\prime}$ & $108^{\circ} 56^{\prime}$ & 396.9 & 1922 \\
\hline 34 & ZhengZhou & 57083 & $34^{\circ} 43^{\prime}$ & $113^{\circ} 39^{\prime}$ & 110.4 & 1930 \\
\hline 35 & HanZhong & 57127 & $33^{\circ} 04^{\prime}$ & $107^{\circ} 12^{\prime}$ & 508.4 & 1932 \\
\hline 36 & YiChang & 57461 & $30^{\circ} 42^{\prime}$ & $111^{\circ} 18^{\prime}$ & 133.1 & 1882 \\
\hline 37 & WuHan & 57494 & $30^{\circ} 37^{\prime}$ & $114^{\circ} 08^{\prime}$ & 23.3 & 1880 \\
\hline 38 & ChongQing & 57516 & $29^{\circ} 35^{\prime}$ & $106^{\circ} 28^{\prime}$ & 259.1 & 1891 \\
\hline 39 & ChangSha & 57679 & $28^{\circ} 12^{\prime}$ & $113^{\circ} 05^{\prime}$ & 44.9 & 1909 \\
\hline 40 & ZhiJiang & 57745 & $27^{\circ} 27^{\prime}$ & $109^{\circ} 41^{\prime}$ & 272.2 & 1938 \\
\hline 41 & GuiYang & 57816 & $26^{\circ} 35^{\prime}$ & $106^{\circ} 43^{\prime}$ & 1071.2 & 1920 \\
\hline 42 & XuZhou & 58027 & $34^{\circ} 17^{\prime}$ & $117^{\circ} 09^{\prime}$ & 41.0 & 1915 \\
\hline 43 & QingJiang & 58144 & $33^{\circ} 36^{\prime}$ & $119^{\circ} 02^{\prime}$ & 17.5 & 1913 \\
\hline
\end{tabular}


Table 3. (continued)

\begin{tabular}{|c|c|c|c|c|c|c|}
\hline & Station name & $\begin{array}{l}\text { Station } \\
\text { number }\end{array}$ & Latitude $^{a}$ & Longitude $^{b}$ & Elevation (m) & $\begin{array}{l}\text { Beginning of } \\
\text { period of } \\
\text { recordc }\end{array}$ \\
\hline 44 & NanJing & 58238 & $32^{\circ} 03^{\prime}$ & $118^{\circ} 47^{\prime}$ & 8.9 & 1905 \\
\hline 45 & ShangHai & 58367 & $31^{\circ} 10^{\prime}$ & $121^{\circ} 26^{\prime}$ & 4.5 & 1871 \\
\hline 46 & AnQing & 58424 & $30^{\circ} 32^{\prime}$ & $117^{\circ} 03^{\prime}$ & 19.8 & 1931 \\
\hline 47 & HangZhou & 58457 & $30^{\circ} 14^{\prime}$ & $120^{\circ} 10^{\prime}$ & 41.7 & 1904 \\
\hline 48 & NanChang & 58606 & $28^{\circ} 36^{\prime}$ & $115^{\circ} 55^{\prime}$ & 46.7 & 1929 \\
\hline 49 & QuZhou & 58633 & $28^{\circ} 58^{\prime}$ & $118^{\circ} 53^{\prime}$ & 66.9 & 1950 \\
\hline 50 & WenZhou & 58659 & $28^{\circ} 01^{\prime}$ & $120^{\circ} 40^{\prime}$ & 7.1 & 1883 \\
\hline 51 & FuZhou & 58847 & $26^{\circ} 05^{\prime}$ & $119^{\circ} 17^{\prime}$ & 83.8 & 1880 \\
\hline 52 & YongAn & 58921 & $25^{\circ} 58^{\prime}$ & $117^{\circ} 21^{\prime}$ & 206.0 & 1938 \\
\hline 53 & LiuZhou & 59046 & $24^{\circ} 28^{\prime}$ & $109^{\circ} 22^{\prime}$ & 97.6 & 1936 \\
\hline 54 & XiaMen & 59134 & $24^{\circ} 29^{\prime}$ & $118^{\circ} 04^{\prime}$ & 139.4 & 1886 \\
\hline 55 & WuZhou & 59265 & $23^{\circ} 29^{\prime}$ & $111^{\circ} 18^{\prime}$ & 119.2 & 1898 \\
\hline 56 & GuangZhou & 59287 & $23^{\circ} 08^{\prime}$ & $113^{\circ} 19^{\prime}$ & 6.6 & 1908 \\
\hline 57 & ShanTou & 59316 & $23^{\circ} 24^{\prime}$ & $116^{\circ} 41^{\prime}$ & 1.2 & 1880 \\
\hline 58 & NanNing & 59431 & $22^{\circ} 49^{\prime}$ & $108^{\circ} 21^{\prime}$ & 72.2 & 1907 \\
\hline 59 & ZhanJiang & 59658 & $21^{\circ} 13^{\prime}$ & $110^{\circ} 24^{\prime}$ & 25.3 & 1913 \\
\hline 60 & HaiKou & 59758 & $20^{\circ} 02^{\prime}$ & $110^{\circ} 21^{\prime}$ & 14.1 & 1912 \\
\hline
\end{tabular}

${ }^{a}$ North

${ }^{b}$ East

' Obtained from data base, station histories may give a different year. 

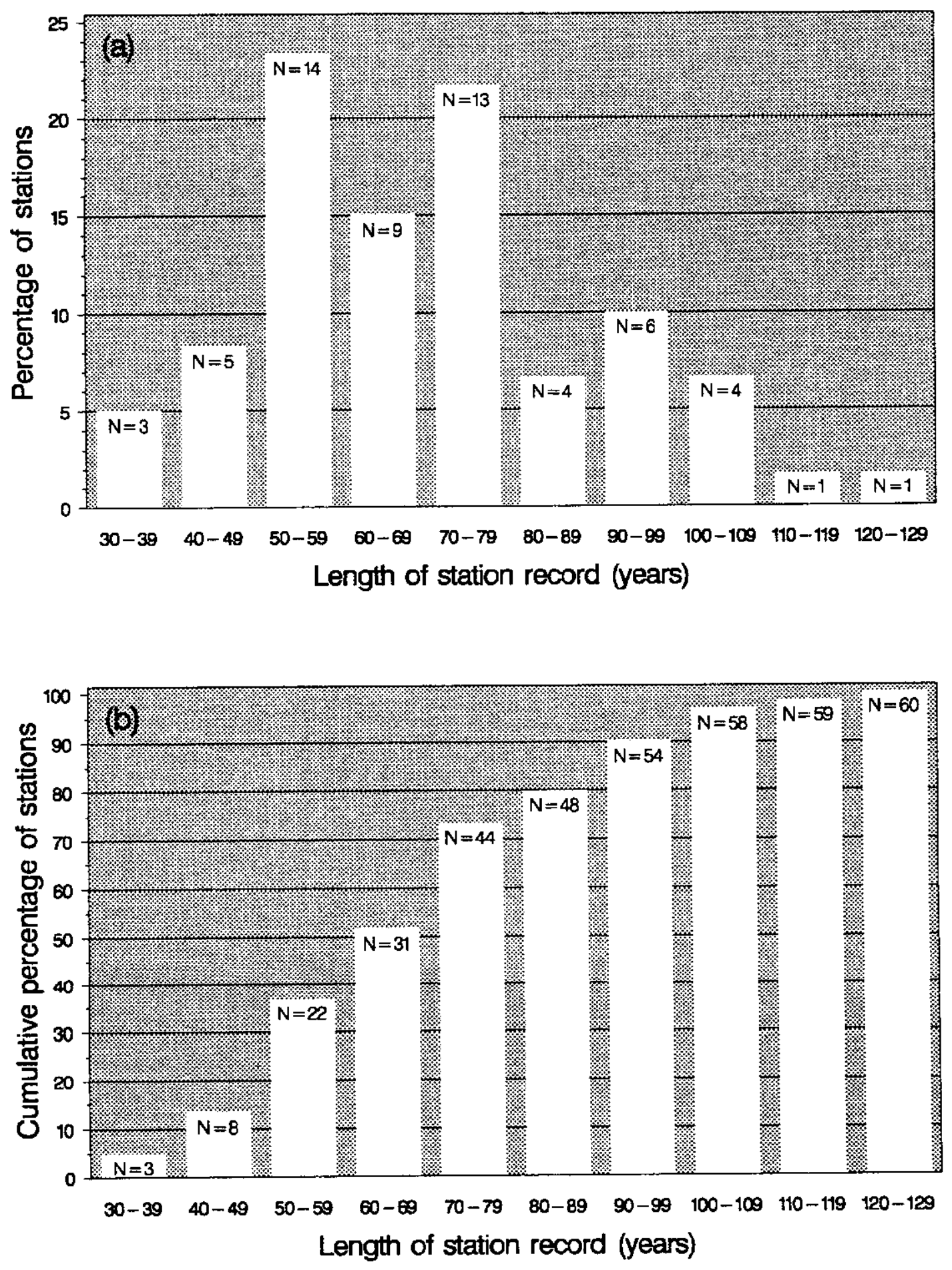

Fig. 1. Percentage (a) and cumulative percentage (b) of stations from the PRC 60-station climate network with given record lengths. 


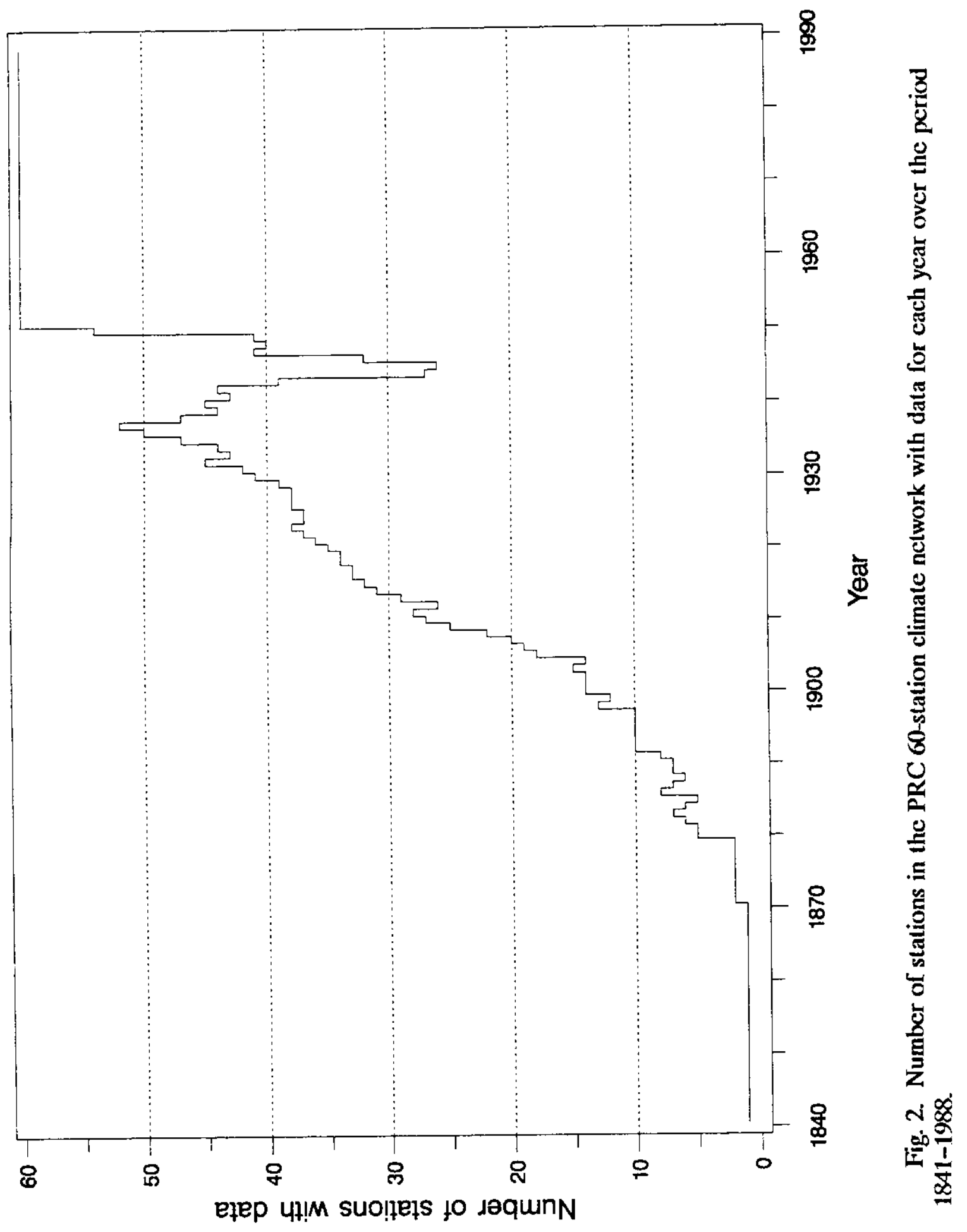


Table 4. Gaps in the periods of record of stations in the PRC 60-station climate network

\begin{tabular}{|c|c|c|c|c|c|}
\hline \multirow[b]{2}{*}{1} & \multirow{2}{*}{$\begin{array}{l}\text { Station name } \\
\text { Hailaer }\end{array}$} & \multirow{2}{*}{$\begin{array}{c}\text { Station number } \\
50527\end{array}$} & \multicolumn{3}{|c|}{ Years with no data } \\
\hline & & & $1933-1934$ & 1943-1949 & \\
\hline 2 & NenJiang & 50557 & 1946-1948 & & \\
\hline 3 & BoKeTu & 50632 & $1933-1950$ & & \\
\hline 4 & QiQiHaEr & 50745 & $1944-1948$ & & \\
\hline 5 & $\mathrm{HaErBin}$ & 50953 & $1907-1908$ & 1944-1948 & \\
\hline 6 & Yi Ning & $51431^{a}$ & & & \\
\hline 7 & WuLuMuQi & 51463 & 1909 & $1912-1929$ & $1931-1940$ \\
\hline 8 & $\mathrm{HaMi}$ & $52203^{a}$ & & & \\
\hline 9 & Jiu Quan & $52533^{a}$ & & & \\
\hline 10 & ZhangYe & 52652 & $1942-1950$ & & \\
\hline 11 & XiNing & $52866^{a}$ & & & \\
\hline 12 & LanZhou & $52889^{a}$ & & & \\
\hline 13 & HuHeHaoTe & 53463 & 1938 & $1944-1945$ & \\
\hline 14 & YinChuan & 53614 & 1939-1949 & & \\
\hline 15 & YuLin & 53646 & 1949 & & \\
\hline 16 & TaiYuan & 53772 & 1938 & 1944-1945 & 1949 \\
\hline 17 & MuDanJiang & 54094 & $1933-1936$ & $1944-1948$ & \\
\hline 18 & ChangChun & 54161 & 1944-1946 & & \\
\hline 19 & ShenYang & 54342 & 1944-1946 & & \\
\hline \multirow[t]{3}{*}{20} & BeiJing & 54511 & $1856-1858$ & $1862-1867$ & 1885 \\
\hline & & & $1887-1888$ & $1901-1902$ & 1904 \\
\hline & & & 1909 & $1912-1913$ & 1938-1939 \\
\hline 21 & TianJin & 54527 & 1935 & & \\
\hline 22 & BaoDing & 54602 & $1940-1943$ & 1944-1949 & \\
\hline 23 & DaLian & $54662^{a}$ & & & \\
\hline 24 & YanTai & 54765 & 1944-1949 & & \\
\hline 25 & JiNan & $54823^{a}$ & & & \\
\hline 26 & QingDao & $54857^{a}$ & & & \\
\hline 27 & $\mathrm{LaSa}$ & 55591 & 1939 & 1950 & \\
\hline 28 & ChengDu & 56294 & $1912-1922$ & $1930-1931$ & \\
\hline 29 & XiChang & $56571^{a}$ & & & \\
\hline 30 & TengChong & 56739 & $1942-1950$ & & \\
\hline 31 & KunMing & 56778 & $1904-1950$ & $1915-1917$ & \\
\hline 32 & TianShui & 57006 & 1941 & & \\
\hline 33 & XiAn & 57036 & $1928-1930$ & & \\
\hline 34 & ZhengZhou & 57083 & 1939-1949 & & \\
\hline 35 & HanZhong & 57127 & 1946 & & \\
\hline 36 & YiChang & 57461 & 1939-1946 & & \\
\hline 37 & WuHan & 57494 & 1884 & 1941-1946 & \\
\hline 38 & ChongQing & $57516^{a}$ & & & \\
\hline 39 & ChangSha & 57679 & 1939 & $1941-1945$ & \\
\hline
\end{tabular}


Table 4. (continued)

\begin{tabular}{llllll}
\hline & & & & & \\
& Station name & Station number & & & \\
& & & & & \\
40 & ZhiJiang & $57745^{\circ}$ & & & \\
41 & GuiYang & $57816^{\circ}$ & & & \\
42 & XuZhou & 58027 & $1924-1925$ & 1938 & 1948 \\
43 & QingJiang & 58144 & $1924-1927$ & $1939-1946$ & 1949 \\
44 & NanJing & 58238 & $1938-1945$ & & \\
45 & ShangHai & $58367^{\circ}$ & & & \\
46 & AnQing & 58424 & $1939-1941$ & $1943-1949$ & \\
47 & HangZhou & 58457 & $1938-1941$ & $1943-1944$ & $1948-1949$ \\
48 & NanChang & 58606 & $1939-1945$ & & \\
49 & QuZhou & $58633^{\circ}$ & & & \\
50 & WenZhou & 58659 & 1885 & $1943-1945$ & \\
51 & FuZhou & 58847 & $1886-1891$ & 1899 & \\
52 & YongAn & 58921 & 1949 & & \\
53 & LiuZhou & $59046^{\circ}$ & & & \\
54 & XiaMen & 59134 & $1888-1891$ & $1943-1946$ & \\
55 & WuZhou & 59265 & 1945 & & \\
56 & GuangZhou & 59287 & $1944-1946$ & & \\
57 & ShanTou & 59316 & $1944-1949$ & & \\
58 & NanNing & 59431 & $1916-1920$ & & \\
59 & ZhanJiang & 59658 & $1940-1949$ & & \\
60 & HaiKou & 59758 & $1944-1946$ & & \\
& & & & & \\
\hline
\end{tabular}

${ }^{a}$ At least partial data are available for all years in the station's period of record. 
15

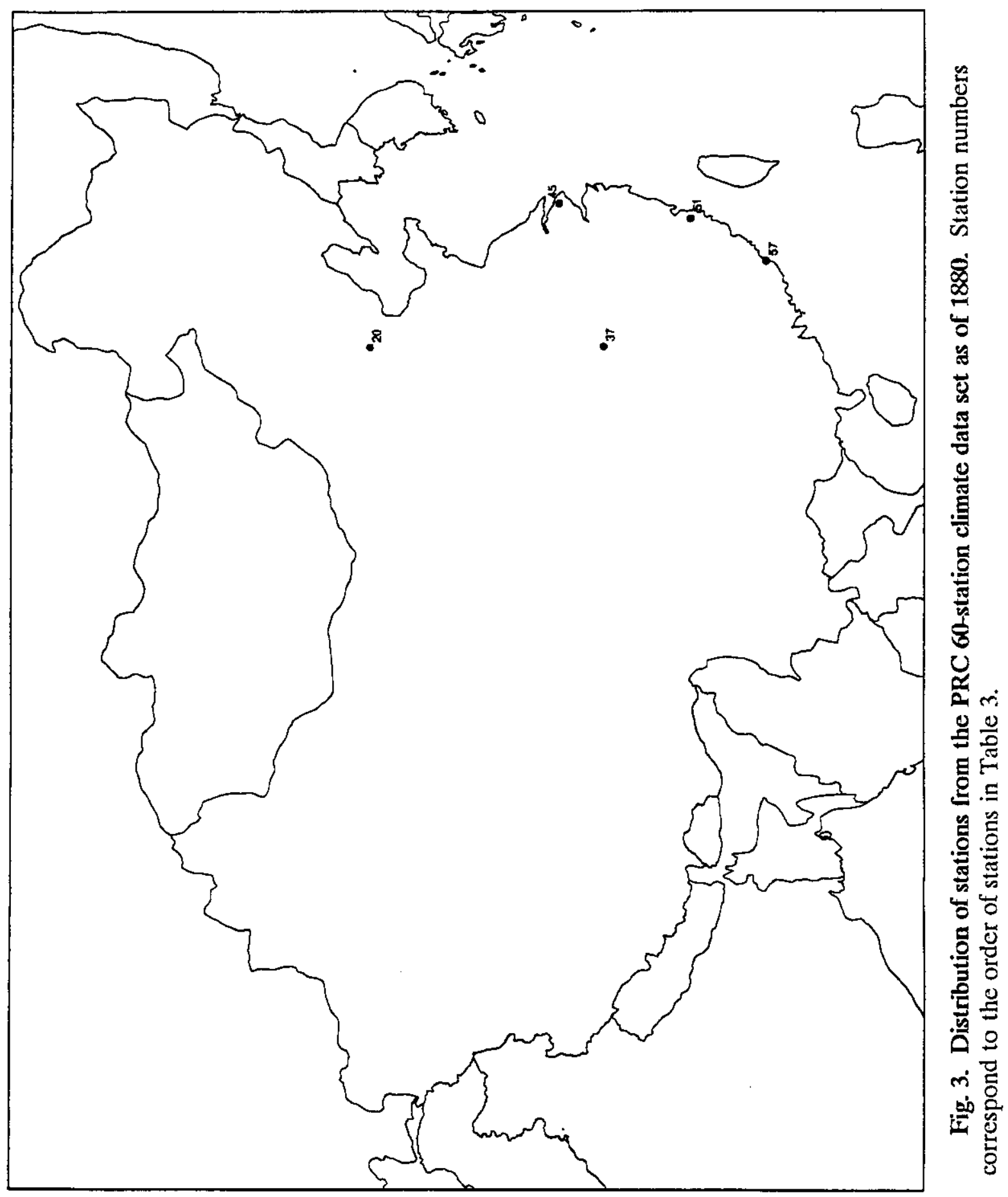



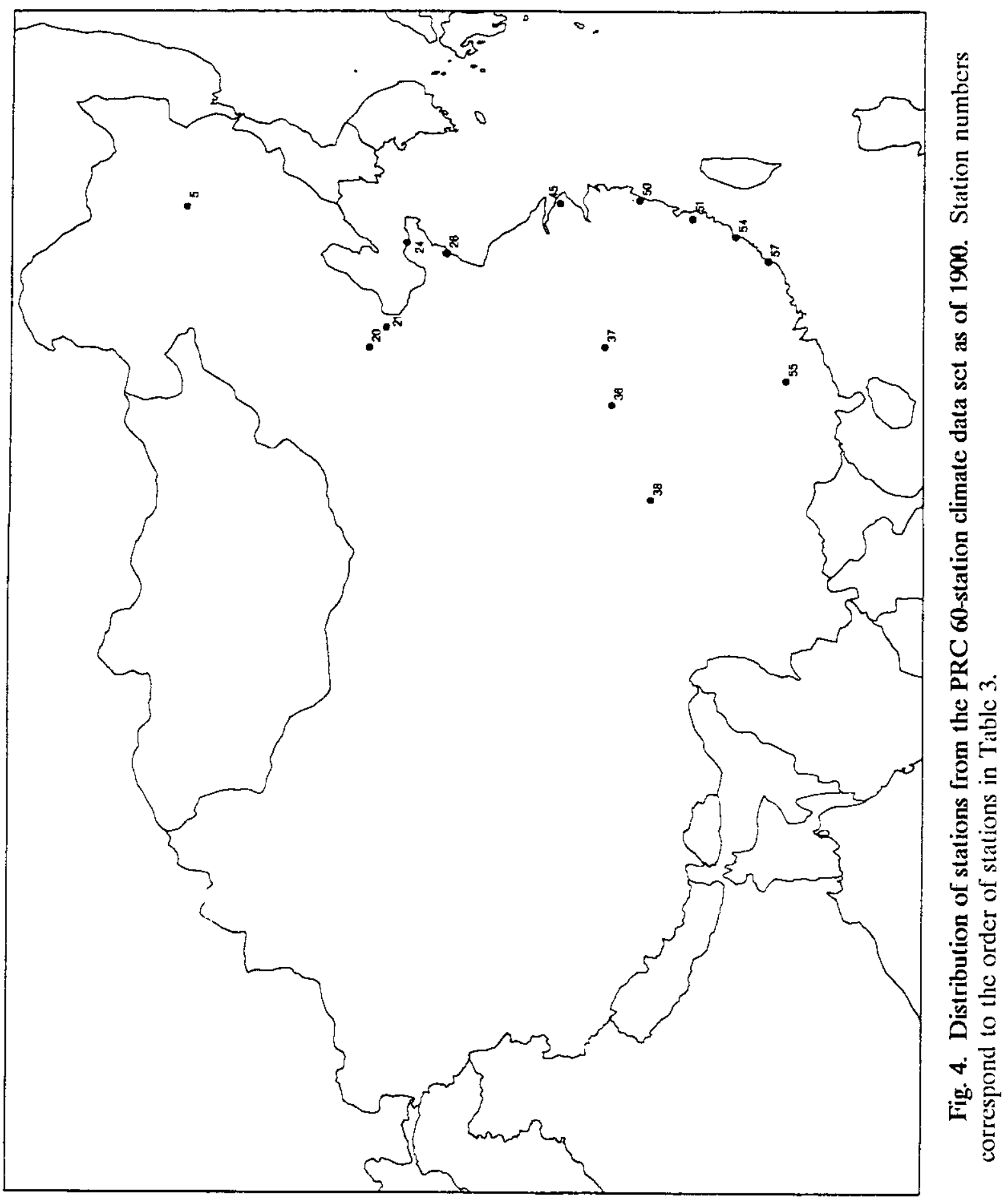
17

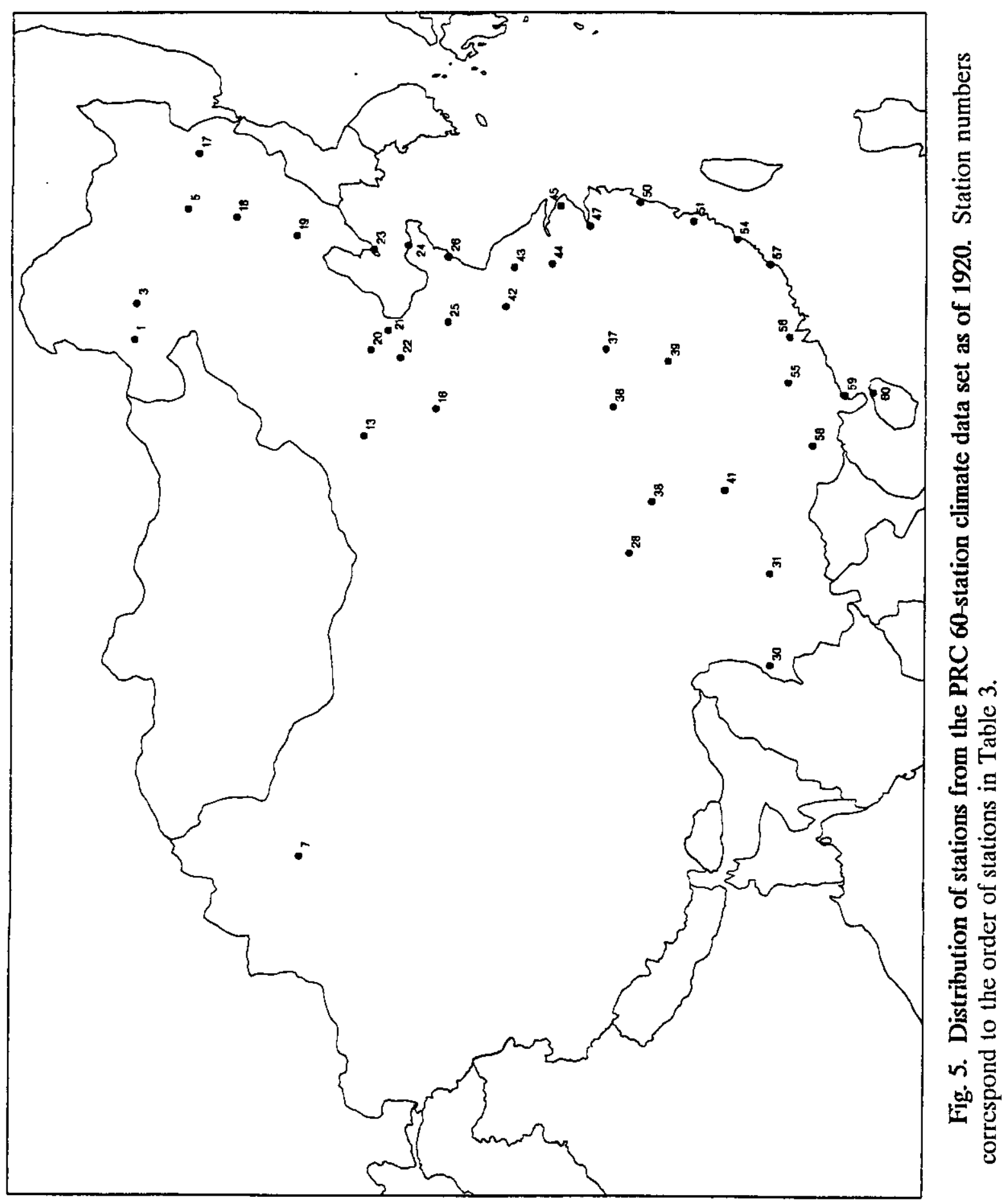




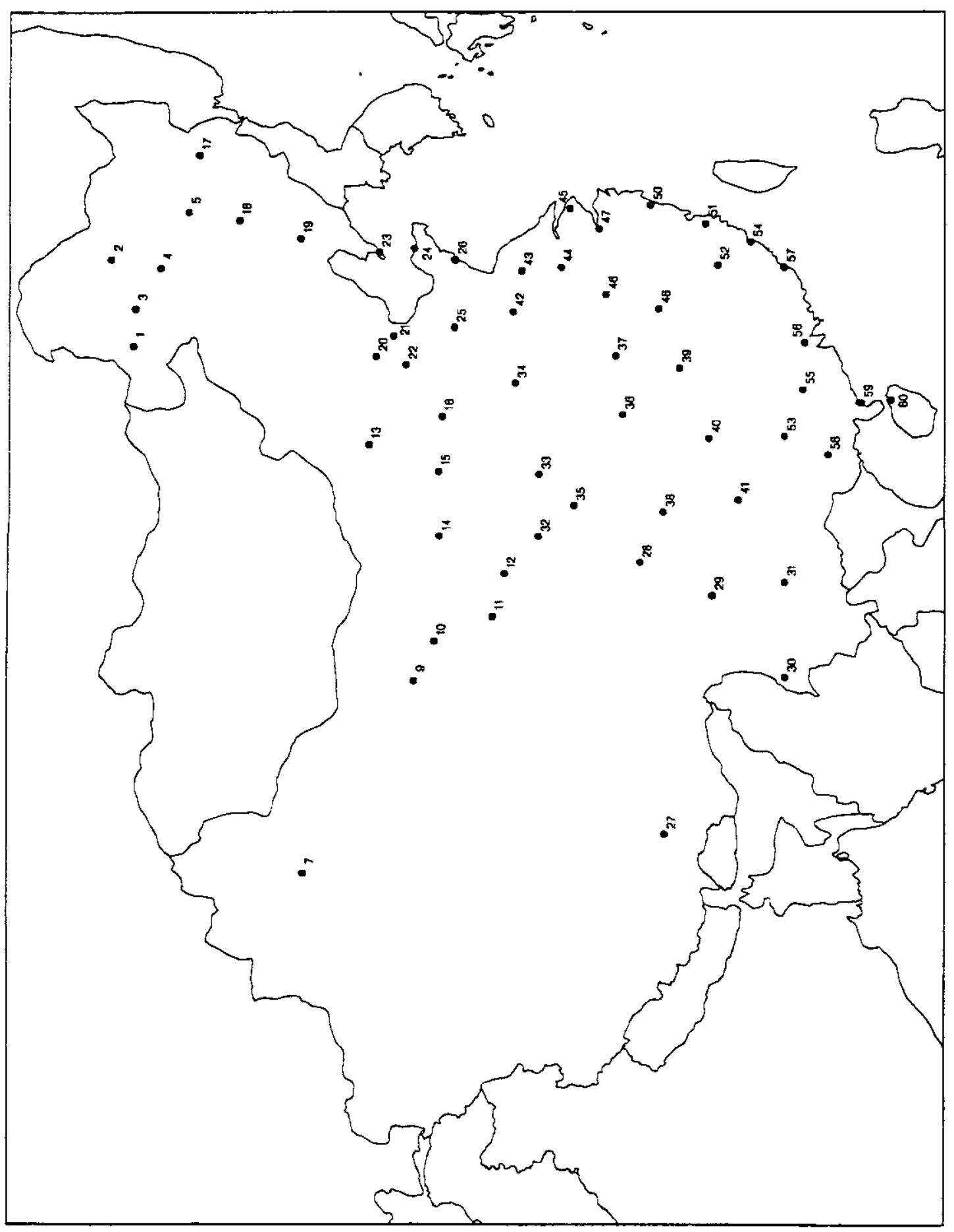

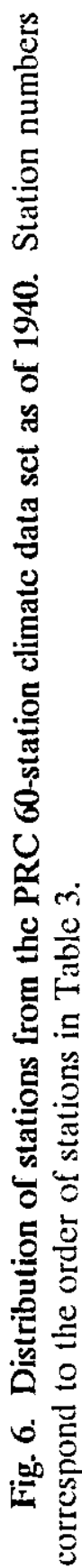


19

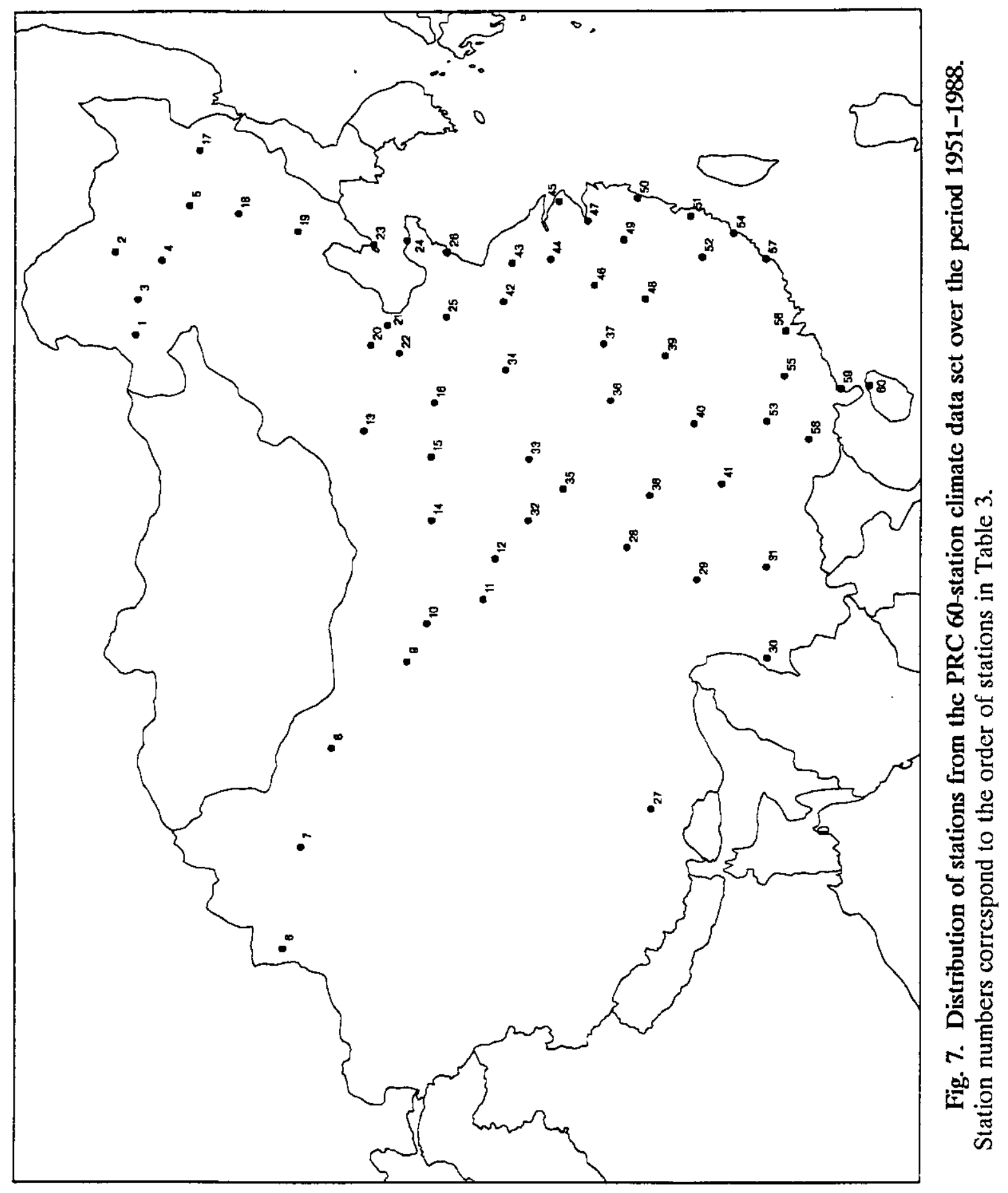




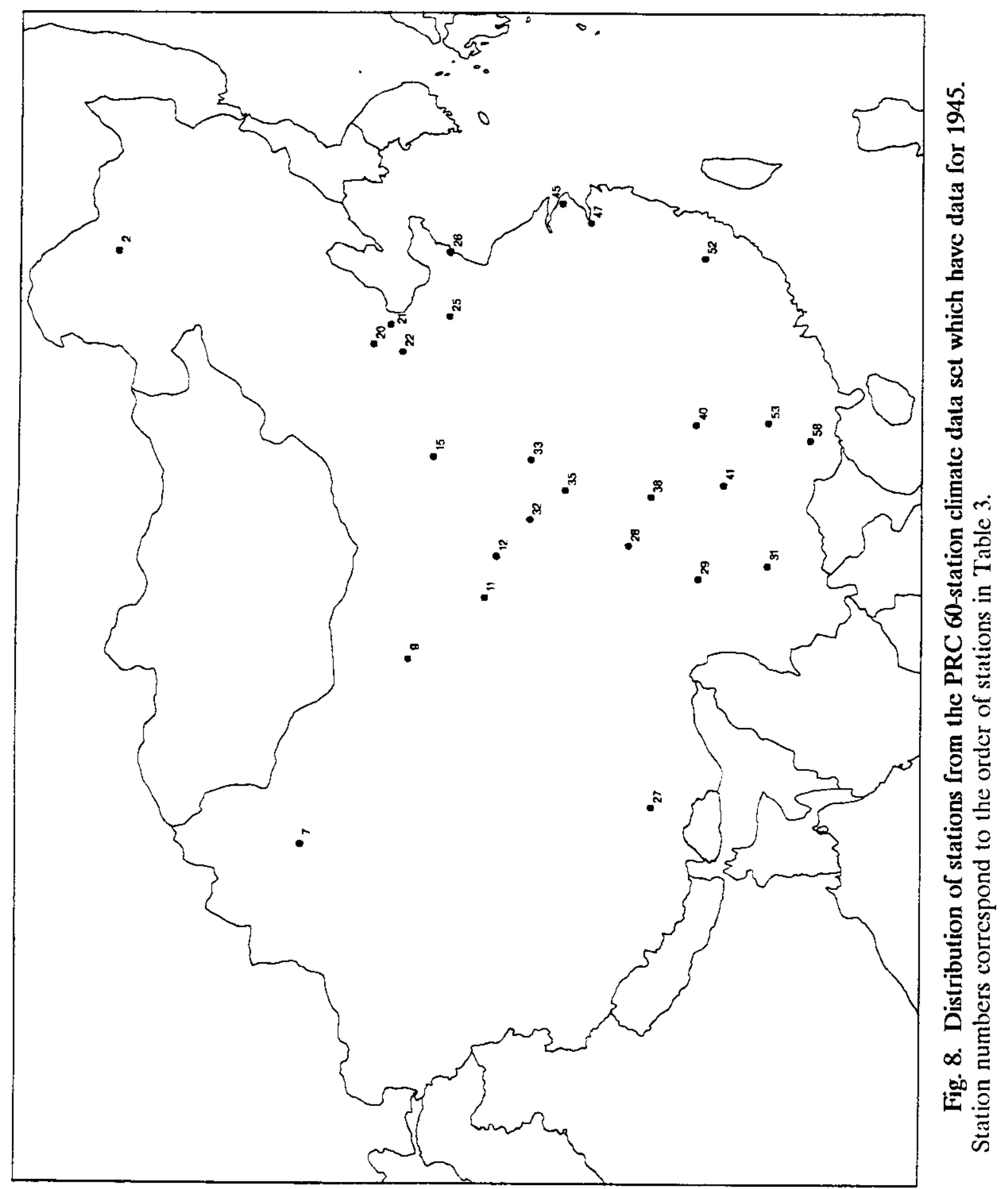




\section{5-STATION NETWORK}

The data from the 205-station network contain two variables: monthly mean temperature and total monthly precipitation. The data are stored in two files, one with temperatures (in tenths of degrees Celsius) and the other with precipitation totals (in tenths of millimeters), samples of which are shown in Tables 5 and 6, respectively. Each record of a file contains data from one year: the WMO station number and year followed by twelve monthly data values. Missing values are represented by "-9999". An inventory of the 205 stations is given in Table 7. The temperature data date back to 1907 (Jingzhou, No. 57476), and the precipitation data to 1880 (Wuhu, No. 58334). Temperature and precipitation records from 202 stations extend through 1988. Records from Geershiquanhe (No. 55228), Hekou (No. 56989), and Lingling (No. 57866) extend through 1982, 1980, and 1983, respectively.

As with the 60-station network, percentage plots have been prepared for the 205-station network showing the relative length of station records. These are shown separately for temperature records (Fig. 9) and precipitation records (Fig. 10). The ranges of station record length reflect the number of years for which the station has at least partial data, which is often less than the number of years since the station opened. As with the 60-station network, this has much to do with World War II's effect on station operations, as illustrated in Fig. 11, which shows the number of stations with temperature and precipitation data for each year over the period 1880-1988. (Because of their relatively small number, years without data have been left in these data sets rather than detailing them separately as with the 60 -station data set.) Figures 9 and 10 show that for both temperature and precipitation data, the most typical length of record ranges between $30-40$ years, with a relatively small share of stations [ 29 stations $(\sim 15 \%)$ for temperature data; 24 stations $(-12 \%)$ for precipitation data] having records for 50 or more years. It is evident from comparing Figs. 9 and 10 with Fig. 1 that the 60-station data set offers more truly long-term records and, as previously noted, contains temperature and/or precipitation data from the beginning of each station record.

Maps depicting the evolution of the 205-station temperature and precipitation network are given in Figs. 12-17. Figures 12-16 show, for temperature and precipitation data individually, the locations of stations which had been opened as of 1900,1920, and 1940. Each station shown on these maps does not necessarily have data for that particular year. Figure 17 shows the network in 1961, the first year all 205 stations had temperature and precipitation data. Numbers plotted on these maps at station locations correspond to the station identification numbers at the left of Table 7. The locations of stations actually having data for 1945 (one of two especially affected years in the era of decreased coverage caused by World War II) are shown separately for temperature and precipitation data in Figs. 18 and 19. Unfortunately, station histories are not currently available for any stations in the 205-station network; therefore, details regarding instrumentation, collection methods, changes in station location or observing times, and official data sources are not known. 
Table 5. Sample listing of the PRC 205-station monthly mean temperature data set ${ }^{a}$

\begin{tabular}{|c|c|c|c|c|c|c|c|c|c|c|c|c|c|}
\hline $\begin{array}{l}50136 \\
50136 \\
50136 \\
50136 \\
50136 \\
50136 \\
50136 \\
50136 \\
50136 \\
50136 \\
50136 \\
50136 \\
50136 \\
50136 \\
50136 \\
50136 \\
50136 \\
50136 \\
50136 \\
50136 \\
50136 \\
50136 \\
50136 \\
50136 \\
50136 \\
50136 \\
50136 \\
50136 \\
50136 \\
50136 \\
50136\end{array}$ & $\begin{array}{l}1958 \\
1959 \\
1960 \\
1961 \\
1962 \\
1963 \\
1964 \\
1965 \\
1966 \\
1967 \\
1968 \\
1969 \\
1970 \\
1971 \\
1972 \\
1973 \\
1974 \\
1975 \\
1976 \\
1977 \\
1978 \\
1979 \\
1980 \\
1981 \\
1982 \\
1983 \\
1984 \\
1985 \\
1986 \\
1987 \\
1988\end{array}$ & $\begin{array}{l}-309 \\
-300 \\
-345 \\
-338 \\
-9999 \\
-261 \\
-274 \\
-329 \\
-317 \\
-285 \\
-291 \\
-351 \\
-311 \\
-315 \\
-335 \\
-319 \\
-321 \\
-293 \\
-257 \\
-311 \\
-309 \\
-321 \\
-304 \\
-281 \\
-274 \\
-272 \\
-287 \\
-333 \\
-275 \\
-332 \\
-270\end{array}$ & $\begin{array}{l}-251 \\
-237 \\
-249 \\
-250 \\
-9999 \\
-221 \\
-248 \\
-279 \\
-299 \\
-234 \\
-218 \\
-344 \\
-256 \\
-279 \\
-280 \\
-242 \\
-272 \\
-269 \\
-283 \\
-277 \\
-243 \\
-259 \\
-228 \\
-267 \\
-226 \\
-272 \\
-265 \\
-261 \\
-224 \\
-224 \\
-241\end{array}$ & $\begin{array}{r}-168 \\
-103 \\
-182 \\
-139 \\
-9999 \\
-139 \\
-129 \\
-157 \\
-187 \\
-134 \\
-97 \\
-173 \\
-160 \\
-150 \\
-137 \\
-146 \\
-156 \\
-119 \\
-166 \\
-143 \\
-149 \\
-152 \\
-175 \\
-159 \\
-153 \\
-92 \\
-152 \\
-156 \\
-114 \\
-162 \\
-155\end{array}$ & $\begin{array}{r}-32 \\
5 \\
-36 \\
-20 \\
-9999 \\
-32 \\
-21 \\
-20 \\
-44 \\
10 \\
36 \\
-16 \\
5 \\
-32 \\
-7 \\
-27 \\
-7 \\
25 \\
-1 \\
-13 \\
13 \\
-3 \\
-37 \\
23 \\
26 \\
-11 \\
5 \\
6 \\
-11 \\
-21 \\
12\end{array}$ & $\begin{array}{r}86 \\
91 \\
67 \\
81 \\
-9999 \\
70 \\
89 \\
82 \\
93 \\
98 \\
95 \\
73 \\
86 \\
102 \\
74 \\
89 \\
75 \\
110 \\
86 \\
91 \\
84 \\
107 \\
76 \\
89 \\
87 \\
85 \\
112 \\
90 \\
90 \\
62 \\
81\end{array}$ & $\begin{array}{r}149 \\
169 \\
161 \\
133 \\
-9999 \\
148 \\
151 \\
150 \\
152 \\
163 \\
156 \\
149 \\
173 \\
182 \\
137 \\
179 \\
153 \\
175 \\
135 \\
160 \\
158 \\
163 \\
166 \\
144 \\
164 \\
131 \\
157 \\
161 \\
182 \\
163 \\
171\end{array}$ & $\begin{array}{r}-9999 \\
171 \\
190 \\
176 \\
.9999 \\
195 \\
172 \\
174 \\
180 \\
191 \\
199 \\
182 \\
195 \\
179 \\
169 \\
199 \\
202 \\
180 \\
188 \\
177 \\
168 \\
184 \\
193 \\
192 \\
186 \\
171 \\
180 \\
181 \\
191 \\
172 \\
189\end{array}$ & $\begin{array}{r}-9999 \\
178 \\
161 \\
158 \\
-9999 \\
171 \\
147 \\
150 \\
157 \\
149 \\
152 \\
163 \\
154 \\
155 \\
134 \\
146 \\
162 \\
156 \\
145 \\
153 \\
153 \\
140 \\
165 \\
140 \\
152 \\
155 \\
143 \\
152 \\
153 \\
164 \\
173\end{array}$ & $\begin{array}{r}74 \\
111 \\
74 \\
82 \\
-9999 \\
83 \\
71 \\
71 \\
75 \\
62 \\
68 \\
65 \\
75 \\
88 \\
84 \\
97 \\
87 \\
70 \\
91 \\
72 \\
72 \\
76 \\
76 \\
05 \\
65 \\
101 \\
83 \\
78 \\
48 \\
73 \\
94\end{array}$ & $\begin{array}{r}-23 \\
-14 \\
-50 \\
-30 \\
-9999 \\
-15 \\
-43 \\
-13 \\
-11 \\
-4 \\
-36 \\
-25 \\
-59 \\
-6 \\
-41 \\
-45 \\
-58 \\
-30 \\
-56 \\
-40 \\
-26 \\
-47 \\
-44 \\
-24 \\
-45 \\
-36 \\
-46 \\
-29 \\
-49 \\
-16 \\
-10\end{array}$ & $\begin{array}{l}-166 \\
-206 \\
-201 \\
-181 \\
-9999 \\
-167 \\
-198 \\
-226 \\
-216 \\
-183 \\
-217 \\
-189 \\
-204 \\
-145 \\
-237 \\
-175 \\
-216 \\
-171 \\
-227 \\
-205 \\
-154 \\
-222 \\
-173 \\
-196 \\
-192 \\
-158 \\
-198 \\
-161 \\
-181 \\
-227 \\
-147\end{array}$ & $\begin{array}{r}-280 \\
-281 \\
-289 \\
-277 \\
-9999 \\
-266 \\
-316 \\
-353 \\
-309 \\
-255 \\
-335 \\
-287 \\
-274 \\
-263 \\
-309 \\
-279 \\
-322 \\
-242 \\
-328 \\
-304 \\
-274 \\
-286 \\
-283 \\
-252 \\
-260 \\
-270 \\
-315 \\
-279 \\
-275 \\
-291 \\
-232\end{array}$ \\
\hline
\end{tabular}

${ }^{a}$ Missing values are represented by -9999 . 
Table 6. Sample listing of the PRC 205-station monthly precipitation data set ${ }^{a}$

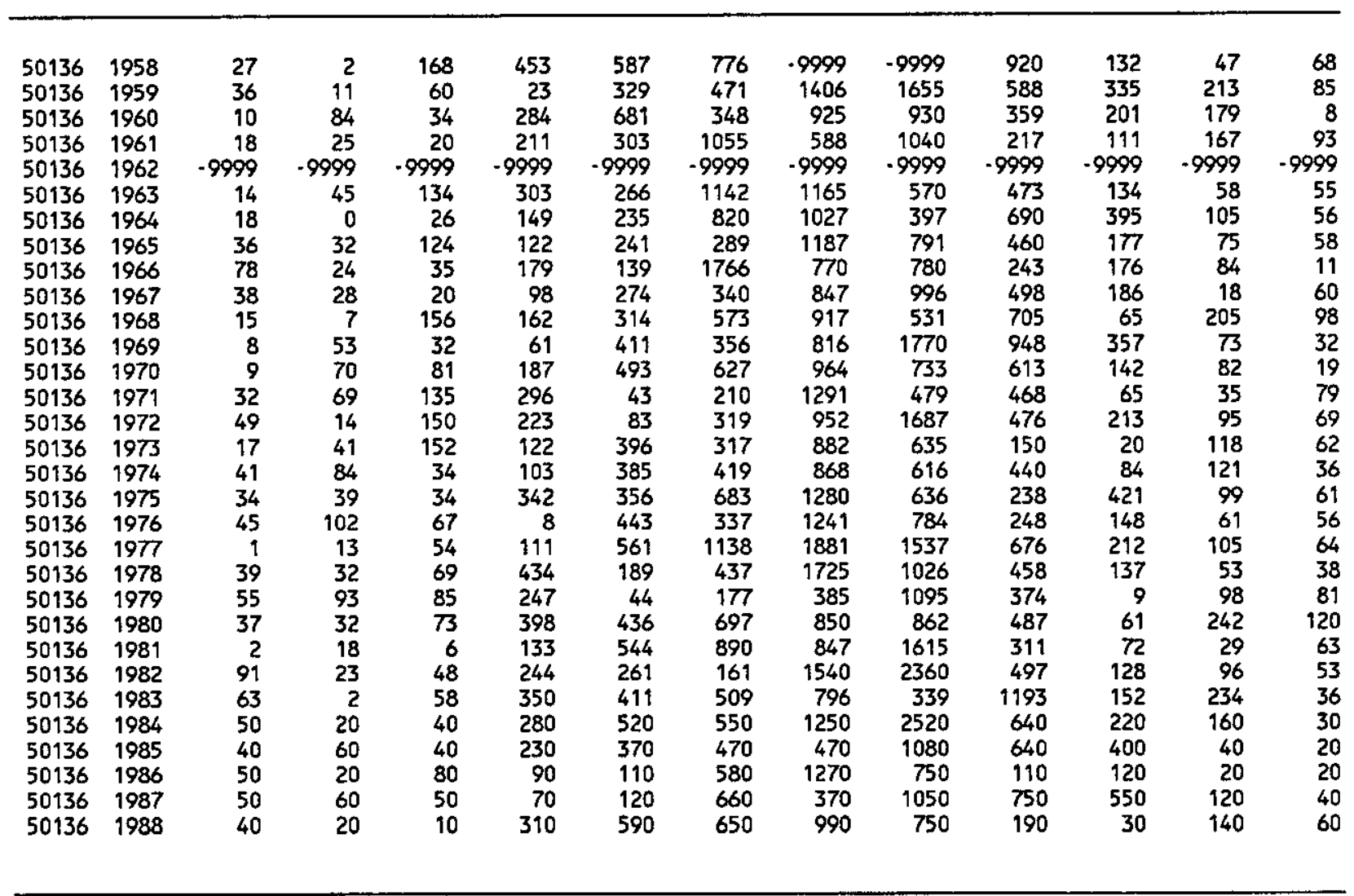

${ }^{a}$ Missing values are represented by -9999 . 
Table 7. Inventory of stations in the PRC 205-station temperature and precipitation network

\begin{tabular}{|c|c|c|c|c|c|c|c|}
\hline & \multirow[b]{2}{*}{ Station name } & \multirow{2}{*}{$\begin{array}{l}\text { Station } \\
\text { number }\end{array}$} & \multirow[b]{2}{*}{ Latitude $^{a}$} & \multirow[b]{2}{*}{ Longitude $^{b}$} & \multirow[b]{2}{*}{ Elevation $^{c}$} & \multicolumn{2}{|c|}{$\begin{array}{l}\text { First year } \\
\text { of record }\end{array}$} \\
\hline & & & & & & Temp. & Precip. \\
\hline 1 & Humamehe & 50136 & $53^{\circ} 28^{\prime}$ & $122^{\circ} 22^{\prime}$ & 296.0 & 1958 & 1958 \\
\hline 2 & Huma & 50353 & $51^{\circ} 43^{\prime}$ & $126^{\circ} 39^{\prime}$ & 177.4 & 1954 & 1954 \\
\hline 3 & Xuguitu Qi Tulihe & 50434 & $50^{\circ} 29^{\prime}$ & $121^{\circ} 41^{\prime}$ & 732.6 & 1957 & 1957 \\
\hline 4 & Sunwu & 50564 & $49^{\circ} 26^{\prime}$ & $127^{\circ} 21^{\prime}$ & 234.5 & 1954 & 1954 \\
\hline 5 & Keshan & 50658 & $48^{\circ} 03^{\prime}$ & $125^{\circ} 53^{\prime}$ & 236.9 & 1936 & 1936 \\
\hline 6 & Horqing Youyi Qianq & 50727 & $47^{\circ} 10^{\prime}$ & $119^{\circ} 57^{\prime}$ & 1027.2 & 1953 & 1938 \\
\hline 7 & Hailun & 50756 & $47^{\circ} 26^{\prime}$ & $126^{\circ} 58^{\prime}$ & 239.2 & 1933 & 1933 \\
\hline 8 & Yichun & 50774 & $47^{\circ} 43^{\prime}$ & $128^{\circ} 54^{\prime}$ & 231.3 & 1956 & 1956 \\
\hline 9 & Fujin & 50788 & $47^{\circ} 14^{\prime}$ & $131^{\circ} 59^{\prime}$ & 64.2 & 1936 & 1936 \\
\hline 10 & Anda & 50854 & $46^{\circ} 23^{\prime}$ & $125^{\circ} 19^{\prime}$ & 149.3 & 1914 & 1914 \\
\hline 11 & Dong Ujimqin Qi & 50915 & $45^{\circ} 31^{\prime}$ & $116^{\circ} 58^{\prime}$ & 838.7 & 1956 & 1956 \\
\hline 12 & Qian Gorlos & 50949 & $45^{\circ} 07^{\prime}$ & $124^{\circ} 50^{\prime}$ & 134.7 & 1953 & 1953 \\
\hline 13 & Tonghe & 50963 & $45^{\circ} 58^{\prime}$ & $128^{\circ} 44^{\prime}$ & 108.6 & 1953 & 1936 \\
\hline 14 & Jixi & 50978 & $45^{\circ} 17^{\prime}$ & $130^{\circ} 57^{\prime}$ & 232.8 & 1949 & 1951 \\
\hline 15 & Altay & 51076 & $47^{\circ} 44^{\prime}$ & $88^{\circ} 05^{\prime}$ & 735.3 & 1938 & 1954 \\
\hline 16 & Tacheng & 51133 & $46^{\circ} 44^{\prime}$ & $83^{\circ} 00^{\prime}$ & 548.0 & 1940 & 1954 \\
\hline 17 & Hoboksar & 51156 & $46^{\circ} 47^{\prime}$ & $85^{\circ} 43^{\prime}$ & 1291.6 & 1954 & 1954 \\
\hline 18 & Jinghe & 51334 & $44^{\circ} 37^{\prime}$ & $82^{\circ} 54^{\prime}$ & 320.1 & 1953 & 1953 \\
\hline 19 & Qitai & 51379 & $44^{\circ} 01^{\prime}$ & $89^{\circ} 34^{\prime}$ & 793.6 & 1952 & 1952 \\
\hline 20 & Hami Qijiaojing & 51495 & $43^{\circ} 29^{\prime}$ & $91^{\circ} 38^{\prime}$ & 873.2 & 1953 & 1953 \\
\hline 21 & Turpan & 51573 & $42^{\circ} 56^{\prime}$ & $89^{\circ} 12^{\prime}$ & 34.5 & 1952 & 1952 \\
\hline 22 & Kuqa & 51644 & $41^{\circ} 43^{\prime}$ & $82^{\circ} 57^{\prime}$ & 1099.0 & 1951 & 1951 \\
\hline 23 & Kashi & 51709 & $39^{\circ} 28^{\prime}$ & $75^{\circ} 59^{\prime}$ & 1288.7 & 1951 & 1951 \\
\hline 24 & Bachu & 51716 & $39^{\circ} 48^{\prime}$ & $78^{\circ} 34^{\prime}$ & 1116.5 & 1954 & 1954 \\
\hline 25 & Ruoqiang & 51777 & $39^{\circ} 02^{\prime}$ & $88^{\circ} 10^{\prime}$ & 888.3 & 1954 & 1954 \\
\hline 26 & Shache & 51811 & $38^{\circ} 26^{\prime}$ & $77^{\circ} 16^{\prime}$ & 1231.2 & 1954 & 1954 \\
\hline 27 & Hotan & 51828 & $37^{\circ} 08^{\prime}$ & $79^{\circ} 56^{\prime}$ & 1374.6 & 1942 & 1954 \\
\hline 28 & Qiemo & 51855 & $38^{\circ} 09^{\prime}$ & $85^{\circ} 33^{\prime}$ & 1247.5 & 1954 & 1954 \\
\hline 29 & Ejin Qi & 52267 & $41^{\circ} 57^{\prime}$ & $101^{\circ} 04^{\prime}$ & 940.5 & 1960 & 1960 \\
\hline 30 & Yemajie & 52323 & $41^{\circ} 35^{\prime}$ & $96^{\circ} 53^{\prime}$ & 1962.7 & 1958 & 1958 \\
\hline 31 & Dunhuang & 52418 & $40^{\circ} 09^{\prime}$ & $94^{\circ} 41^{\prime}$ & 1138.7 & 1938 & 1951 \\
\hline 32 & Anxi & 52424 & $40^{\circ} 32^{\prime}$ & $95^{\circ} 46^{\prime}$ & 1170.8 & 1939 & 1951 \\
\hline 33 & Yumenzhen & 52436 & $40^{\circ} 16^{\prime}$ & $97^{\circ} 02^{\prime}$ & 1526.0 & 1953 & 1953 \\
\hline 34 & Lengh & 52602 & $38^{\circ} 50^{\prime}$ & $93^{\circ} 23^{\prime}$ & 2733.0 & 1957 & 1957 \\
\hline 35 & Qilian Tuole & 52633 & $38^{\circ} 49^{\prime}$ & $98^{\circ} 25^{\prime}$ & 3360.7 & 1957 & 1957 \\
\hline 36 & Minqin & 52681 & $38^{\circ} 38^{\prime}$ & $103^{\circ} 05^{\prime}$ & 1367.0 & 1953 & 1953 \\
\hline 37 & Da Qaidam & 52713 & $37^{\circ} 51^{\prime}$ & $95^{\circ} 22^{\prime}$ & 3173.2 & 1957 & 1957 \\
\hline 38 & Tianzhu Wushaoling & 52787 & $37^{\circ} 12^{\prime}$ & $102^{\circ} 52^{\prime}$ & 3045.1 & 1951 & 1951 \\
\hline 39 & Golmud & 52818 & $36^{\circ} 25^{\prime}$ & $94^{\circ} 54^{\prime}$ & 2807.7 & 1956 & 1956 \\
\hline 40 & Dulan & 52836 & $36^{\circ} 18^{\prime}$ & $98^{\circ} 06^{\prime}$ & 3191.1 & 1940 & 1954 \\
\hline 41 & Uulan Caka & 52842 & $36^{\circ} 47^{\prime}$ & $99^{\circ} 05^{\prime}$ & 3087.6 & 1956 & 1956 \\
\hline
\end{tabular}


Table 7. (continued)

\begin{tabular}{|c|c|c|c|c|c|c|c|}
\hline & \multirow[b]{2}{*}{ Station name } & \multirow{2}{*}{$\begin{array}{l}\text { Station } \\
\text { number }\end{array}$} & \multirow[b]{2}{*}{ Latitude $^{a}$} & \multirow[b]{2}{*}{ Longitude $^{b}$} & \multirow[b]{2}{*}{ Elevation $^{c}$} & \multicolumn{2}{|c|}{$\begin{array}{l}\text { First year } \\
\text { of record }\end{array}$} \\
\hline & & & & & & Temp. & Precip \\
\hline 42 & Gonghe & 52856 & $36^{\circ} 16^{\prime}$ & $100^{\circ} 37^{\prime}$ & 2835.0 & 1953 & 1953 \\
\hline 43 & Linxia & 52984 & $35^{\circ} 35^{\prime}$ & $103^{\circ} 11^{\prime}$ & 1917.0 & 1943 & 1951 \\
\hline 44 & Tongwei Huajialing & 52996 & $35^{\circ} 23^{\prime}$ & $105^{\circ} 00^{\prime}$ & 2450.6 & 1943 & 1951 \\
\hline 45 & Erenhot & 53068 & $43^{\circ} 39^{\prime}$ & $111^{\circ} 58^{\prime}$ & 964.7 & 1956 & 1956 \\
\hline 46 & Abag Qi & 53192 & $44^{\circ} 01^{\prime}$ & $114^{\circ} 57^{\prime}$ & 1126.1 & 1953 & 1953 \\
\hline 47 & Sonid Youqi & 53276 & $42^{\circ} 24^{\prime}$ & $112^{\circ} 54^{\prime}$ & 1150.5 & 1953 & 1953 \\
\hline 48 & Urad Zhongqi & 53336 & $41^{\circ} 34^{\prime}$ & $108^{\circ} 31^{\prime}$ & 1288.2 & 1954 & 1954 \\
\hline 49 & Darhan Muminggan & 53352 & $41^{\circ} 42^{\prime}$ & $110^{\circ} 26^{\prime}$ & 1375.9 & 1939 & 1954 \\
\hline 50 & Huade & 53391 & $41^{\circ} 54^{\prime}$ & $114^{\circ} 00^{\prime}$ & 1482.5 & 1953 & 1953 \\
\hline 51 & Datong & 53487 & $40^{\circ} 06^{\prime}$ & $113^{\circ} 20^{\prime}$ & 1067.2 & 1921 & 1919 \\
\hline 52 & Alxa Youqi Jartai & 53502 & $39^{\circ} 47^{\prime}$ & $105^{\circ} 45^{\prime}$ & 1031.8 & 1955 & 1955 \\
\hline 53 & Otog Qi & 53529 & $39^{\circ} 06^{\prime}$ & $107^{\circ} 59^{\prime}$ & 1380.3 & 1955 & 1955 \\
\hline 54 & Wutaishan & 53588 & $39^{\circ} 02^{\prime}$ & $113^{\circ} 32^{\prime}$ & 2895.8 & 1956 & 1956 \\
\hline 55 & Weixian & 53593 & $39^{\circ} 50^{\prime}$ & $114^{\circ} 34^{\prime}$ & 909.5 & 1954 & 1922 \\
\hline 56 & Alxa Zuoqi & 53602 & $38^{\circ} 50^{\prime}$ & $105^{\circ} 40^{\prime}$ & 1561.4 & 1953 & 1953 \\
\hline 57 & Xingxian & 53664 & $38^{\circ} 28^{\prime}$ & $111^{\circ} 08^{\prime}$ & 1012.6 & 1921 & 1955 \\
\hline 58 & Zhongning & 53705 & $37^{\circ} 29^{\prime}$ & $105^{\circ} 40^{\prime}$ & 1183.3 & 1939 & 1953 \\
\hline 59 & Yanchi & 53723 & $37^{\circ} 47^{\prime}$ & $107^{\circ} 24^{\prime}$ & 1347.8 & 1954 & 1954 \\
\hline 60 & Xingtai & 53798 & $37^{\circ} 04^{\prime}$ & $114^{\circ} 30^{\prime}$ & 76.8 & 1954 & 1922 \\
\hline 61 & Yanan & 53845 & $36^{\circ} 36^{\prime}$ & $109^{\circ} 30^{\prime}$ & 957.6 & 1945 & 1952 \\
\hline 62 & Jiexiu & 53863 & $37^{\circ} 03^{\prime}$ & $111^{\circ} 56^{\prime}$ & 748.8 & 1921 & 1921 \\
\hline 63 & Anyang & 53898 & $36^{\circ} 07^{\prime}$ & $114^{\circ} 22^{\prime}$ & 75.5 & 1932 & 1919 \\
\hline 64 & Pingliang & 53915 & $35^{\circ} 33^{\prime}$ & $106^{\circ} 40^{\prime}$ & 1346.6 & 1937 & 1951 \\
\hline 65 & Qingyang Xifengzhen & 53923 & $35^{\circ} 44^{\prime}$ & $107^{\circ} 38^{\prime}$ & 1421.9 & 1937 & 1951 \\
\hline 66 & Yuncheng & 53959 & $35^{\circ} 02^{\prime}$ & $111^{\circ} 01^{\prime}$ & 376.0 & 1939 & 1956 \\
\hline 67 & Jarud Qi & 54026 & $44^{\circ} 34^{\prime}$ & $120^{\circ} 54^{\prime}$ & 265.0 & 1953 & 1953 \\
\hline 68 & Bairin Zuoqi & 54027 & $43^{\circ} 59^{\prime}$ & $119^{\circ} 24^{\prime}$ & 484.4 & 1953 & 1953 \\
\hline 69 & Suifenhe & 54096 & $44^{\circ} 23^{\prime}$ & $131^{\circ} 09^{\prime}$ & 496.7 & 1936 & 1936 \\
\hline 70 & Abagnar Qi & 54102 & $43^{\circ} 57^{\prime}$ & $116^{\circ} 04^{\prime}$ & 989.5 & 1939 & 1953 \\
\hline 71 & Linxi & 54115 & $43^{\circ} 36^{\prime}$ & $118^{\circ} 04^{\prime}$ & 779.0 & 1936 & 1936 \\
\hline 72 & Tongliao & 54135 & $43^{\circ} 36^{\prime}$ & $122^{\circ} 16^{\prime}$ & 178.5 & 1936 & 1936 \\
\hline 73 & Siping & 54157 & $43^{\circ} 11^{\prime}$ & $124^{\circ} 20^{\prime}$ & 164.2 & 1934 & 1934 \\
\hline 74 & Dunhua & 54186 & $43^{\circ} 22^{\prime}$ & $128^{\circ} 12^{\prime}$ & 523.7 & 1931 & 1931 \\
\hline 75 & Duolun & 54208 & $42^{\circ} 11^{\prime}$ & $116^{\circ} 28^{\prime}$ & 1245.4 & 1938 & 1938 \\
\hline 76 & Chifen & 54218 & $42^{\circ} 16^{\prime}$ & $118^{\circ} 58^{\prime}$ & 571.1 & 1936 & 1936 \\
\hline 77 & Fuxin & 54237 & $42^{\circ} 02^{\prime}$ & $121^{\circ} 39^{\prime}$ & 144.0 & 1938 & 1938 \\
\hline 78 & Yanji & 54292 & $42^{\circ} 53^{\prime}$ & $129^{\circ} 28^{\prime}$ & 176.8 & 1914 & 1914 \\
\hline 79 & Weichang & 54311 & $41^{\circ} 56^{\prime}$ & $117^{\circ} 45^{\prime}$ & 842.3 & 1936 & 1936 \\
\hline 80 & Chaoyang & 54324 & $41^{\circ} 33^{\prime}$ & $120^{\circ} 27^{\prime}$ & 169.2 & 1932 & 1908 \\
\hline 81 & Jinzhou & 54337 & $41^{\circ} 08^{\prime}$ & $121^{\circ} 07^{\prime}$ & 65.9 & 1939 & 1936 \\
\hline
\end{tabular}


Table 7. (continued)

\begin{tabular}{|c|c|c|c|c|c|c|c|}
\hline & \multirow[b]{2}{*}{ Station name } & \multirow{2}{*}{$\begin{array}{l}\text { Station } \\
\text { number }\end{array}$} & \multirow[b]{2}{*}{ Latitude $^{a}$} & \multirow[b]{2}{*}{ Longitude $^{b}$} & \multirow[b]{2}{*}{ Elevation $^{c}$} & \multicolumn{2}{|c|}{$\begin{array}{l}\text { First year } \\
\text { of record } \\
\end{array}$} \\
\hline & & & & & & Temp. & Precip. \\
\hline 82 & Tonghua & 54363 & $41^{\circ} 41^{\prime}$ & $125^{\circ} 54^{\prime}$ & 402.9 & 1936 & 1936 \\
\hline 83 & Linjiang & 54374 & $41^{\circ} 43^{\prime}$ & $126^{\circ} 55^{\prime}$ & 332.5 & 1953 & 1938 \\
\hline 84 & Zhangiiakou & 54401 & $40^{\circ} 47^{\prime}$ & $114^{\circ} 53^{\prime}$ & 724.2 & 1937 & 1919 \\
\hline 85 & Chengde & 54423 & $40^{\circ} 58^{\prime}$ & $117^{\circ} 56^{\prime}$ & 375.2 & 1937 & 1922 \\
\hline 86 & Xingcheng & 54455 & $40^{\circ} 35^{\prime}$ & $120^{\circ} 42^{\prime}$ & 8.8 & 1936 & 1936 \\
\hline 87 & Gaixian Xiongyue & 54476 & $40^{\circ} 10^{\prime}$ & $122^{\circ} 09^{\prime}$ & 20.4 & 1914 & 1914 \\
\hline 88 & Kuanding & 54493 & $40^{\circ} 43^{\prime}$ & $124^{\circ} 47^{\prime}$ & 260.1 & 1954 & 1936 \\
\hline 89 & Dandong & 54497 & $40^{\circ} 03^{\prime}$ & $124^{\circ} 20^{\prime}$ & 15.1 & 1924 & 1907 \\
\hline 90 & Cangzhou & 54616 & $38^{\circ} 20^{\prime}$ & $116^{\circ} 50^{\prime}$ & 9.6 & 1954 & 1930 \\
\hline 91 & Dezhou & 54714 & $37^{\circ} 26^{\prime}$ & $116^{\circ} 19^{\prime}$ & 21.2 & 1951 & 1932 \\
\hline 92 & Huimin & 54725 & $37^{\circ} 30^{\prime}$ & $117^{\circ} 32^{\prime}$ & 11.3 & 1933 & 1929 \\
\hline 93 & Rongchengchenshanto & 54776 & $37^{\circ} 24^{\prime}$ & $122^{\circ} 41^{\prime}$ & 47.7 & 1924 & 1886 \\
\hline 94 & Weifang & 54843 & $36^{\circ} 42^{\prime}$ & $119^{\circ} 05^{\prime}$ & 44.1 & 1929 & 1929 \\
\hline 95 & Laiyang & 54852 & $36^{\circ} 56^{\prime}$ & $120^{\circ} 42^{\prime}$ & 30.5 & 1930 & 1932 \\
\hline 96 & Heze & 54906 & $35^{\circ} 15^{\prime}$ & $115^{\circ} 26^{\prime}$ & 49.7 & 1933 & 1931 \\
\hline 97 & Yanzhou & 54916 & $35^{\circ} 34^{\prime}$ & $116^{\circ} 51^{\prime}$ & 51.6 & 1951 & 1951 \\
\hline 98 & Juxian & 54936 & $35^{\circ} 35^{\prime}$ & $118^{\circ} 50^{\prime}$ & 107.4 & 1931 & 1951 \\
\hline 99 & Linyi & 54938 & $35^{\circ} 03^{\prime}$ & $118^{\circ} 21^{\prime}$ & 87.9 & 1932 & 1929 \\
\hline 100 & Geershiquanhe & 55228 & $32^{\circ} 30^{\prime}$ & $80^{\circ} 05^{\prime}$ & 4728.0 & 1961 & 1961 \\
\hline 101 & Nagqu & 55299 & $31^{\circ} 29^{\prime}$ & $92^{\circ} 04^{\prime}$ & 4507.0 & 1955 & 1955 \\
\hline 102 & Xigaze & 55578 & $29^{\circ} 15^{\prime}$ & $88^{\circ} 53^{\prime}$ & 3836.0 & 1956 & 1956 \\
\hline 103 & Lhunze & 55696 & $28^{\circ} 25^{\prime}$ & $92^{\circ} 28^{\prime}$ & 3860.0 & 1960 & 1960 \\
\hline 104 & Qumarleb & 56021 & $34^{\circ} 08^{\prime}$ & $95^{\circ} 47^{\prime}$ & 4175.0 & 1957 & 1957 \\
\hline 105 & Yushu & 56029 & $33^{\circ} 01^{\prime}$ & $97^{\circ} 01^{\prime}$ & 3681.2 & 1954 & 1954 \\
\hline 106 & Madoi & 56033 & $34^{\circ} 55^{\prime}$ & $98^{\circ} 13^{\prime}$ & 4272.3 & 1953 & 1953 \\
\hline 107 & Minxian & 56093 & $34^{\circ} 26^{\prime}$ & $104^{\circ} 01^{\prime}$ & 2314.6 & 1937 & 1951 \\
\hline 108 & Wudu & 56096 & $33^{\circ} 24^{\prime}$ & $104^{\circ} 55^{\prime}$ & 1079.1 & 1944 & 1951 \\
\hline 109 & Qamdo & 56137 & $31^{\circ} 09^{\prime}$ & $97^{\circ} 10^{\prime}$ & 3306.0 & 1941 & 1952 \\
\hline 110 & Garze & 56146 & $31^{\circ} 37^{\prime}$ & $100^{\circ} 00^{\prime}$ & 3393.5 & 1952 & 1951 \\
\hline 111 & Xiaojin & 56178 & $31^{\circ} 00^{\prime}$ & $102^{\circ} 21^{\prime}$ & 2369.2 & 1952 & 1952 \\
\hline 112 & Songpan & 56182 & $32^{\circ} 39^{\prime}$ & $103^{\circ} 34^{\prime}$ & 2850.7 & 1940 & 1951 \\
\hline 113 & Pingwu & 56193 & $32^{\circ} 25^{\prime}$ & $104^{\circ} 31^{\prime}$ & 876.5 & 1937 & 1952 \\
\hline 114 & Mianyang & 56196 & $31^{\circ} 28^{\prime}$ & $104^{\circ} 41^{\prime}$ & 470.8 & 1954 & 1954 \\
\hline 115 & Litang & 56257 & $30^{\circ} 00^{\prime}$ & $100^{\circ} 16^{\prime}$ & 3948.9 & 1953 & 1953 \\
\hline 116 & Yaan & 56287 & $29^{\circ} 59^{\prime}$ & $103^{\circ} 00^{\prime}$ & 627.6 & 1939 & 1951 \\
\hline 117 & Nyingchi & 56312 & $29^{\circ} 34^{\prime}$ & $94^{\circ} 28^{\prime}$ & 3000.0 & 1953 & 1953 \\
\hline 118 & Leshan & 56386 & $29^{\circ} 34^{\prime}$ & $103^{\circ} 45^{\prime}$ & 424.2 & 1936 & 1951 \\
\hline 119 & Jiulong & 56462 & $29^{\circ} 00^{\prime}$ & $101^{\circ} 30^{\prime}$ & 2987.3 & 1953 & 1953 \\
\hline 120 & Leibo & 56485 & $28^{\circ} 16^{\prime}$ & $103^{\circ} 35^{\prime}$ & 1474.9 & 1937 & 1954 \\
\hline 121 & Yibin & 56492 & $28^{\circ} 48^{\prime}$ & $104^{\circ} 36^{\prime}$ & 340.8 & 1932 & 1951 \\
\hline
\end{tabular}


Table 7. (continued)

\begin{tabular}{|c|c|c|c|c|c|c|c|}
\hline & \multirow[b]{2}{*}{ Station name } & \multirow{2}{*}{$\begin{array}{l}\text { Station } \\
\text { number }\end{array}$} & \multirow[b]{2}{*}{ Latitude $^{a}$} & \multirow[b]{2}{*}{ Longitude $^{b}$} & \multirow[b]{2}{*}{ Elevation $^{c}$} & \multicolumn{2}{|c|}{$\begin{array}{l}\text { First year } \\
\text { of record }\end{array}$} \\
\hline & & & & & & Temp. & Precip. \\
\hline 122 & Lijiang & 56651 & $26^{\circ} 52^{\prime}$ & $100^{\circ} 13^{\prime}$ & 2393.2 & 1943 & 1951 \\
\hline 123 & Huili & 56671 & $26^{\circ} 39^{\prime}$ & $102^{\circ} 15^{\prime}$ & 1787.1 & 1938 & 1953 \\
\hline 124 & Weining & 56691 & $26^{\circ} 52^{\prime}$ & $104^{\circ} 17^{\prime}$ & 2237.5 & 1937 & 1951 \\
\hline 125 & Dali & 56751 & $25^{\circ} 42^{\prime}$ & $100^{\circ} 11^{\prime}$ & 1190.5 & 1939 & 1951 \\
\hline 126 & Panxian & 56793 & $25^{\circ} 47^{\prime}$ & $104^{\circ} 37^{\prime}$ & 1527.1 & 1940 & 1951 \\
\hline 127 & Lincang & 56951 & $23^{\circ} 57^{\prime}$ & $100^{\circ} 13^{\prime}$ & 1463.7 & 1954 & 1953 \\
\hline 128 & Jinghong & 56959 & $22^{\circ} 00^{\prime}$ & $100^{\circ} 48^{\prime}$ & 552.7 & 1954 & 1954 \\
\hline 129 & Puer Simao & 56964 & $22^{\circ} 40^{\prime}$ & $101^{\circ} 24^{\prime}$ & 1302.1 & 1952 & 1952 \\
\hline 130 & Mengzi & 56985 & $23^{\circ} 23^{\prime}$ & $103^{\circ} 23^{\prime}$ & 1300.7 & 1928 & 1951 \\
\hline 131 & Hekou & 56989 & $22^{\circ} 30^{\prime}$ & $103^{\circ} 57^{\prime}$ & 1367.0 & 1954 & 1954 \\
\hline 132 & Lushi & 57067 & $34^{\circ} 03^{\prime}$ & $111^{\circ} 02^{\prime}$ & 568.8 & 1953 & 1953 \\
\hline 133 & Luoyang & 57073 & $34^{\circ} 40^{\prime}$ & $112^{\circ} 25^{\prime}$ & 154.5 & 1951 & 1931 \\
\hline 134 & Nanyang & 57178 & $33^{\circ} 02^{\prime}$ & $112^{\circ} 35^{\prime}$ & 129.2 & 1934 & 1932 \\
\hline 135 & Xihua & 57193 & $33^{\circ} 47^{\prime}$ & $114^{\circ} 31^{\prime}$ & 52.6 & 1954 & 1954 \\
\hline 136 & Wanyuan & 57237 & $32^{\circ} 04^{\prime}$ & $108^{\circ} 02^{\prime}$ & 674.0 & 1953 & 1953 \\
\hline 137 & Ankang & 57245 & $32^{\circ} 43^{\prime}$ & $109^{\circ} 02^{\prime}$ & 290.8 & 1953 & 1953 \\
\hline 138 & Yunxian & 57253 & $32^{\circ} 51^{\prime}$ & $110^{\circ} 49^{\prime}$ & 201.9 & 1941 & 1933 \\
\hline 139 & Laohekou & 57265 & $32^{\circ} 23^{\prime}$ & $111^{\circ} 40^{\prime}$ & 90.0 & 1950 & 1933 \\
\hline 140 & Zhumadian & 57290 & $33^{\circ} 00^{\prime}$ & $114^{\circ} 01^{\prime}$ & 82.7 & 1953 & 1922 \\
\hline 141 & Xinyang & 57297 & $32^{\circ} 08^{\prime}$ & $114^{\circ} 03^{\prime}$ & 114.5 & 1932 & 1922 \\
\hline 142 & Bazhong & 57313 & $31^{\circ} 51^{\prime}$ & $106^{\circ} 46^{\prime}$ & 360.0 & 1953 & 1953 \\
\hline 143 & Zhongxiang & 57378 & $31^{\circ} 10^{\prime}$ & $112^{\circ} 34^{\prime}$ & 65.8 & 1953 & 1930 \\
\hline 144 & Suining & 57405 & $30^{\circ} 30^{\prime}$ & $105^{\circ} 35^{\prime}$ & 278.2 & 1936 & 1951 \\
\hline 145 & Nanchong & 57411 & $30^{\circ} 48^{\prime}$ & $106^{\circ} 05^{\prime}$ & 297.7 & 1940 & 1952 \\
\hline 146 & Enshi & 57447 & $30^{\circ} 17^{\prime}$ & $109^{\circ} 28^{\prime}$ & 457.1 & 1951 & 1933 \\
\hline 147 & Jingzhou & 57476 & $30^{\circ} 20^{\prime}$ & $112^{\circ} 11^{\prime}$ & 32.6 & 1907 & 1906 \\
\hline 148 & Neijiang & 57504 & $29^{\circ} 35^{\prime}$ & $105^{\circ} 03^{\prime}$ & 347.1 & 1936 & 1951 \\
\hline 149 & Pengshui & 57537 & $29^{\circ} 18^{\prime}$ & $108^{\circ} 10^{\prime}$ & 310.6 & 1937 & 1951 \\
\hline 150 & Yueyang & 57584 & $29^{\circ} 23^{\prime}$ & $113^{\circ} 05^{\prime}$ & 51.6 & 1924 & 1953 \\
\hline 151 & Tongzi & 57606 & $28^{\circ} 08^{\prime}$ & $105^{\circ} 50^{\prime}$ & 972.0 & 1937 & 1951 \\
\hline 152 & Youyang & 57633 & $28^{\circ} 50^{\prime}$ & $108^{\circ} 46^{\prime}$ & 663.7 & 1938 & 1951 \\
\hline 153 & Yuanling & 57655 & $28^{\circ} 28^{\prime}$ & $110^{\circ} 24^{\prime}$ & 151.6 & 1942 & 1953 \\
\hline 154 & Changde & 57662 & $29^{\circ} 03^{\prime}$ & $111^{\circ} 41^{\prime}$ & 35.0 & 1932 & 1951 \\
\hline 155 & Zunyi & 57713 & $27^{\circ} 42^{\prime}$ & $106^{\circ} 53^{\prime}$ & 843.9 & 1941 & 1951 \\
\hline 156 & Meitan & 57722 & $27^{\circ} 46^{\prime}$ & $107^{\circ} 28^{\prime}$ & 791.8 & 1940 & 1951 \\
\hline 157 & Sinan & 57731 & $27^{\circ} 57^{\prime}$ & $108^{\circ} 15^{\prime}$ & 416.3 & 1940 & 1951 \\
\hline 158 & Shaoyang & 57766 & $27^{\circ} 14^{\prime}$ & $111^{\circ} 28^{\prime}$ & 248.6 & 1936 & 1951 \\
\hline 159 & Yichun & 57793 & $27^{\circ} 48^{\prime}$ & $114^{\circ} 23^{\prime}$ & 131.3 & 1953 & 1953 \\
\hline 160 & Jian & 57799 & $27^{\circ} 07^{\prime}$ & $114^{\circ} 58^{\prime}$ & 76.4 & 1930 & 1930 \\
\hline 161 & Wugang & 57853 & $26^{\circ} 44^{\prime}$ & $110^{\circ} 38^{\prime}$ & 341.0 & 1953 & 1953 \\
\hline
\end{tabular}


Table 7. (continued)

\begin{tabular}{|c|c|c|c|c|c|c|c|}
\hline & \multirow[b]{2}{*}{ Station name } & \multirow{2}{*}{$\begin{array}{l}\text { Station } \\
\text { number }\end{array}$} & \multirow[b]{2}{*}{ Latitude $^{a}$} & \multirow[b]{2}{*}{ Longitude $^{b}$} & \multirow[b]{2}{*}{ Elevation $^{c}$} & \multicolumn{2}{|c|}{$\begin{array}{l}\text { First year } \\
\text { of record }\end{array}$} \\
\hline & & & & & & Temp. & Precip. \\
\hline 162 & Lingling & 57866 & $26^{\circ} 14^{\prime}$ & $111^{\circ} 37^{\prime}$ & 172.6 & 1942 & 1951 \\
\hline 163 & Hengyang & 57872 & $26^{\circ} 54^{\prime}$ & $112^{\circ} 36^{\prime}$ & 103.2 & 1932 & 1951 \\
\hline 164 & Suichang & 57896 & $26^{\circ} 20^{\prime}$ & $114^{\circ} 30^{\prime}$ & 126.1 & 1951 & 1951 \\
\hline 165 & Xingren & 57902 & $25^{\circ} 26^{\prime}$ & $105^{\circ} 11^{\prime}$ & 1378.5 & 1943 & 1951 \\
\hline 166 & Luodian & 57916 & $25^{\circ} 26^{\prime}$ & $106^{\circ} 46^{\prime}$ & 440.3 & 1944 & 1952 \\
\hline 167 & Guilin & 57957 & $25^{\circ} 20^{\prime}$ & $110^{\circ} 18^{\prime}$ & 161.8 & 1935 & 1951 \\
\hline 168 & Chenzhou & 57972 & $25^{\circ} 48^{\prime}$ & $113^{\circ} 02^{\prime}$ & 184.9 & 1936 & 1957 \\
\hline 169 & Ganzhou & 57993 & $25^{\circ} 51^{\prime}$ & $114^{\circ} 57^{\prime}$ & 123.8 & 1939 & 1924 \\
\hline 170 & Haoxian & 58102 & $33^{\circ} 52^{\prime}$ & $115^{\circ} 46^{\prime}$ & 37.7 & 1953 & 1922 \\
\hline 171 & Sheyang & 58150 & $33^{\circ} 46^{\prime}$ & $120^{\circ} 15^{\prime}$ & 2.0 & 1954 & 1953 \\
\hline 172 & Fuyang & 58203 & $32^{\circ} 55^{\prime}$ & $115^{\circ} 49^{\prime}$ & 30.6 & 1953 & 1922 \\
\hline 173 & Bengfu & 58221 & $32^{\circ} 57^{\prime}$ & $117^{\circ} 23^{\prime}$ & 18.7 & 1932 & 1918 \\
\hline 174 & Dongtai & 58251 & $32^{\circ} 51^{\prime}$ & $120^{\circ} 19^{\prime}$ & 4.3 & 1924 & 1924 \\
\hline 175 & Nantong & 58259 & $32^{\circ} 01^{\prime}$ & $120^{\circ} 51^{\prime}$ & 5.3 & 1917 & 1917 \\
\hline 176 & Huoshan & 58314 & $31^{\circ} 24^{\prime}$ & $116^{\circ} 19^{\prime}$ & 68.1 & 1954 & 1954 \\
\hline 177 & Hefei & 58321 & $31^{\circ} 52^{\prime}$ & $117^{\circ} 14^{\prime}$ & 27.9 & 1946 & 1952 \\
\hline 178 & Wuhu & 58334 & $31^{\circ} 20^{\prime}$ & $118^{\circ} 23^{\prime}$ & 14.8 & 1924 & 1880 \\
\hline 179 & Huangshi & 58407 & $30^{\circ} 15^{\prime}$ & $115^{\circ} 03^{\prime}$ & 19.6 & 1954 & 1934 \\
\hline 180 & Dinghai & 58477 & $30^{\circ} 02^{\prime}$ & $122^{\circ} 07^{\prime}$ & 35.7 & 1933 & 1931 \\
\hline 181 & Jiujiang & 58502 & $29^{\circ} 44^{\prime}$ & $116^{\circ} 00^{\prime}$ & 33.2 & 1924 & 1885 \\
\hline 182 & Tunxi & 58531 & $29^{\circ} 43^{\prime}$ & $118^{\circ} 17^{\prime}$ & 145.4 & 1953 & 1953 \\
\hline 183 & Shengxian & 58556 & $29^{\circ} 36^{\prime}$ & $120^{\circ} 49^{\prime}$ & 104.3 & 1933 & 1929 \\
\hline 184 & Li Shui & 58646 & $28^{\circ} 27^{\prime}$ & $119^{\circ} 55^{\prime}$ & 60.8 & 1933 & 1932 \\
\hline 185 & Huangyan & 58665 & $28^{\circ} 38^{\prime}$ & $121^{\circ} 25^{\prime}$ & 1.3 & 1951 & 1932 \\
\hline 186 & Pucheng & 58731 & $27^{\circ} 55^{\prime}$ & $118^{\circ} 32^{\prime}$ & 276.9 & 1935 & 1936 \\
\hline 187 & Jianyang & 58734 & $27^{\circ} 20^{\prime}$ & $118^{\circ} 07^{\prime}$ & 181.1 & 1940 & 1940 \\
\hline 188 & Fuding & 58754 & $27^{\circ} 20^{\prime}$ & $120^{\circ} 12^{\prime}$ & 36.2 & 1953 & 1953 \\
\hline 189 & Guangchang & 58813 & $26^{\circ} 51^{\prime}$ & $116^{\circ} 20^{\prime}$ & 143.8 & 1954 & 1954 \\
\hline 190 & Nanping & 58834 & $26^{\circ} 39^{\prime}$ & $118^{\circ} 10^{\prime}$ & 125.6 & 1935 & 1935 \\
\hline 191 & Dehua Jiuxianshan & 58931 & $25^{\circ} 43^{\prime}$ & $118^{\circ} 06^{\prime}$ & 1653.5 & 1956 & 1956 \\
\hline 192 & Guangnan & 59007 & $24^{\circ} 42^{\prime}$ & $105^{\circ} 04^{\prime}$ & 1249.6 & 1954 & 1954 \\
\hline 193 & Lianxian & 59072 & $24^{\circ} 47^{\prime}$ & $112^{\circ} 23^{\prime}$ & 97.6 & 1952 & 1953 \\
\hline 194 & Shaoguan & 59082 & $24^{\circ} 48^{\prime}$ & $113^{\circ} 35^{\prime}$ & 69.3 & 1946 & 1951 \\
\hline 195 & Meixian & 59117 & $24^{\circ} 16^{\prime}$ & $116^{\circ} 06^{\prime}$ & 87.8 & 1953 & 1953 \\
\hline 196 & Zhangzhou & 59126 & $24^{\circ} 30^{\prime}$ & $117^{\circ} 39^{\prime}$ & 28.9 & 1951 & 1941 \\
\hline 197 & Bose & 59211 & $23^{\circ} 54^{\prime}$ & $106^{\circ} 36^{\prime}$ & 173.5 & 1939 & 1951 \\
\hline 198 & Guiping & 59254 & $23^{\circ} 24^{\prime}$ & $110^{\circ} 05^{\prime}$ & 42.2 & 1953 & 1953 \\
\hline 199 & Heyuan & 59293 & $23^{\circ} 44^{\prime}$ & $114^{\circ} 41^{\prime}$ & 41.1 & 1953 & 1953 \\
\hline 200 & Longzhou & 59417 & $22^{\circ} 22^{\prime}$ & $106^{\circ} 45^{\prime}$ & 128.3 & 1953 & 1953 \\
\hline 201 & Yulin & 59453 & $22^{\circ} 38^{\prime}$ & $110^{\circ} 10^{\prime}$ & 81.8 & 1954 & 1954 \\
\hline
\end{tabular}


Table 7. (continued)

\begin{tabular}{|c|c|c|c|c|c|c|c|}
\hline & \multirow[b]{2}{*}{ Station name } & \multirow{2}{*}{$\begin{array}{l}\text { Station } \\
\text { number }\end{array}$} & \multirow[b]{2}{*}{ Latitude $^{a}$} & \multirow[b]{2}{*}{ Longitude $^{b}$} & \multirow[b]{2}{*}{ Elevation $^{c}$} & \multicolumn{2}{|c|}{$\begin{array}{l}\text { First year } \\
\text { of record }\end{array}$} \\
\hline & & & & & & Temp. & Precip. \\
\hline 202 & Shenzhen & 59493 & $22^{\circ} 33^{\prime}$ & $114^{\circ} 06^{\prime}$ & 18.2 & 1953 & 1953 \\
\hline 203 & Haifen Shanwei & 59501 & $22^{\circ} 47^{\prime}$ & $115^{\circ} 22^{\prime}$ & 4.6 & 1953 & 1953 \\
\hline 204 & Danxian & 59845 & $19^{\circ} 31^{\prime}$ & $109^{\circ} 35^{\prime}$ & 168.7 & 1953 & 1953 \\
\hline 205 & Qionghai & 59855 & $19^{\circ} 14^{\prime}$ & $110^{\circ} 28^{\prime}$ & 24.0 & 1953 & 1953 \\
\hline
\end{tabular}



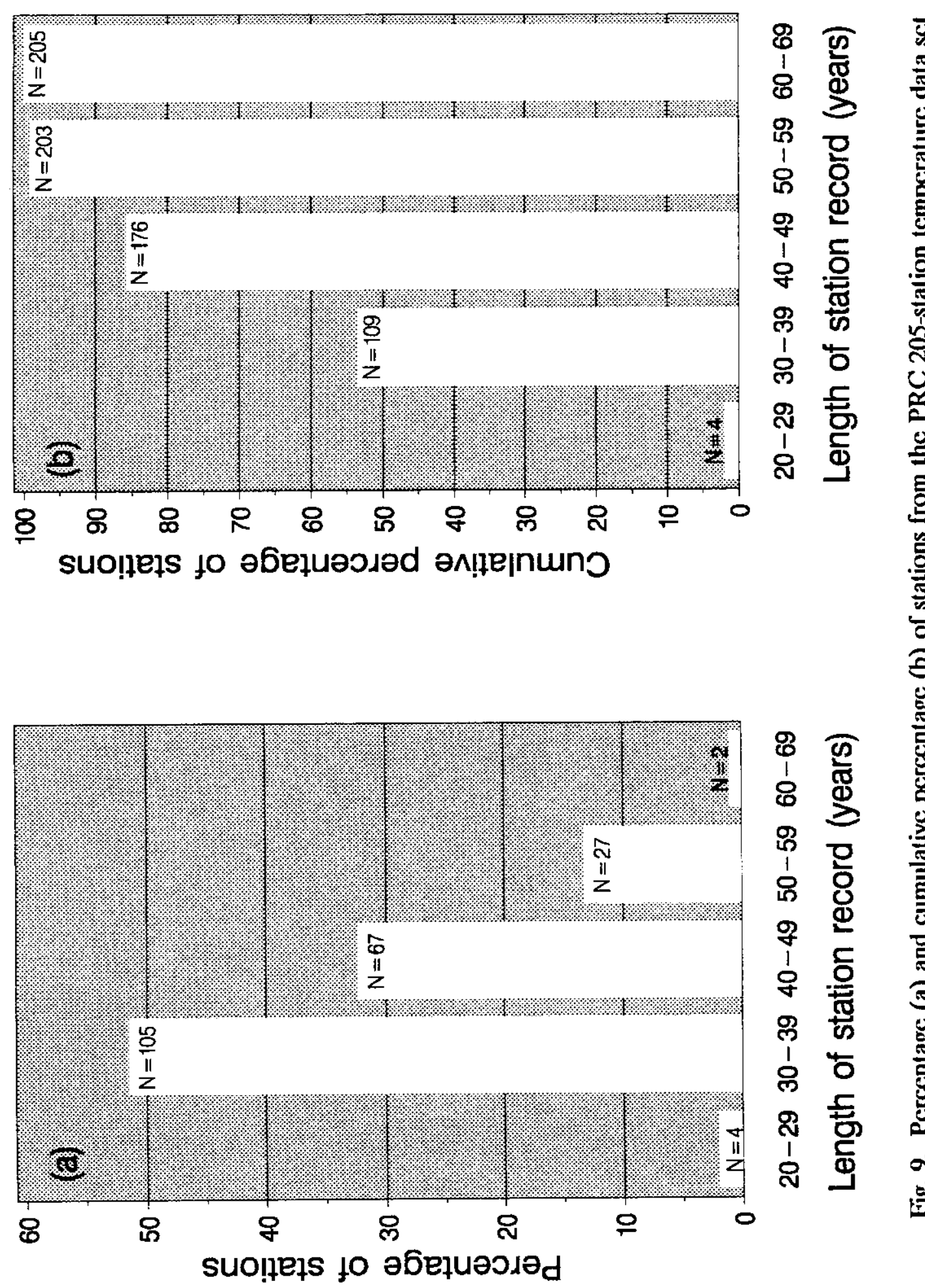

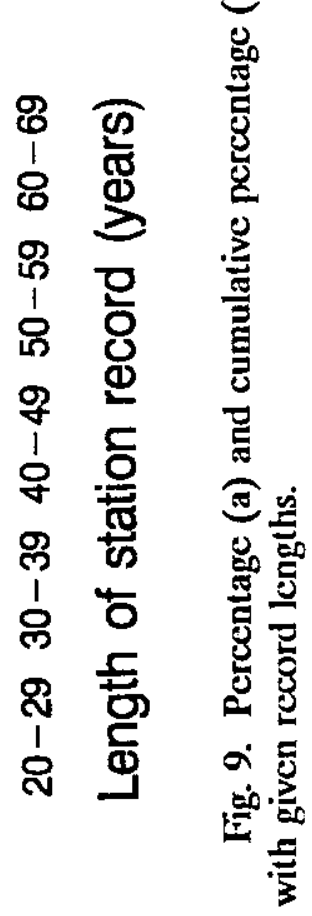



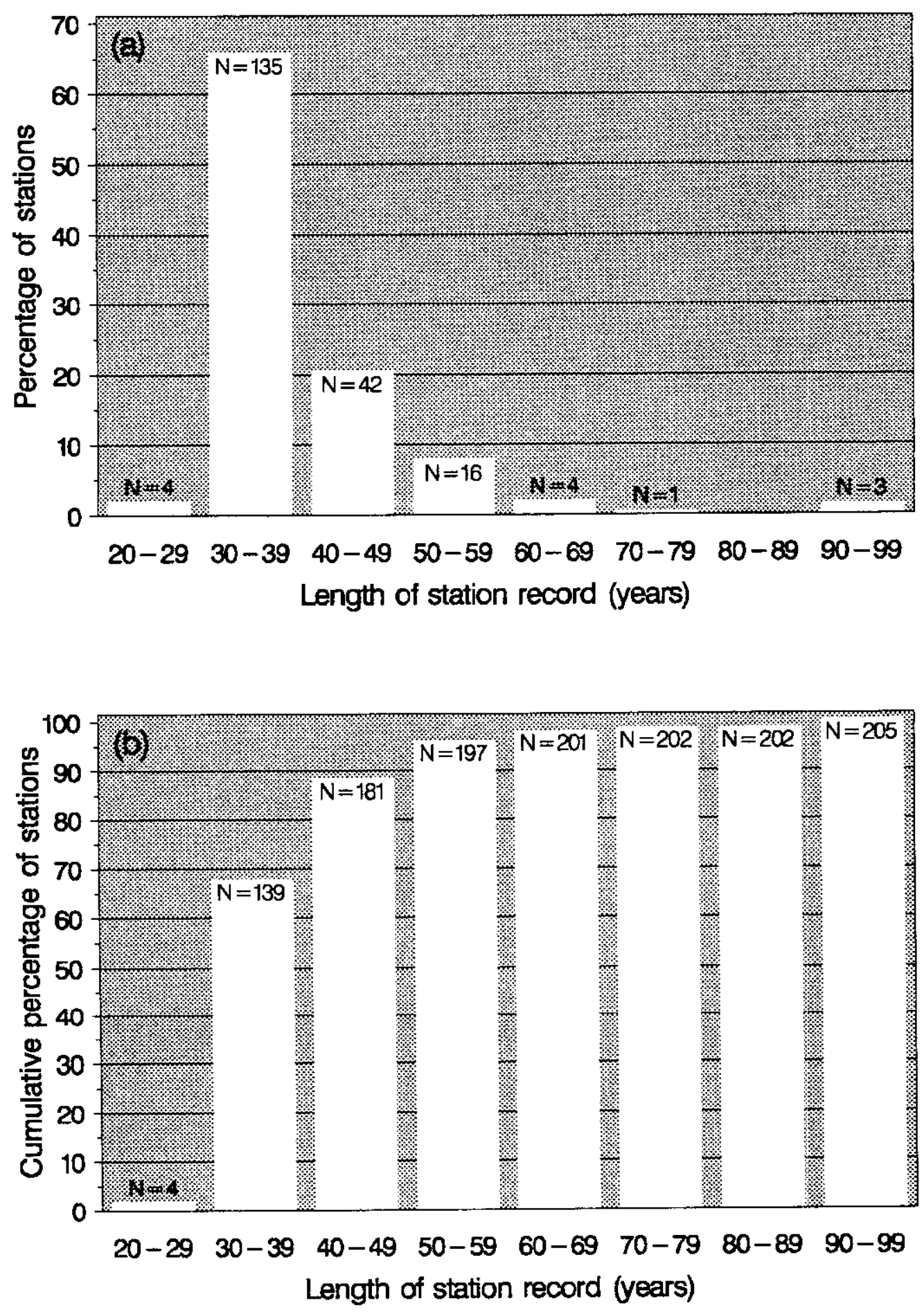

Fig. 10. Percentage (a) and cumulative percentage (b) of stations from the PRC 205-station precipitation data set with given record lengths. 


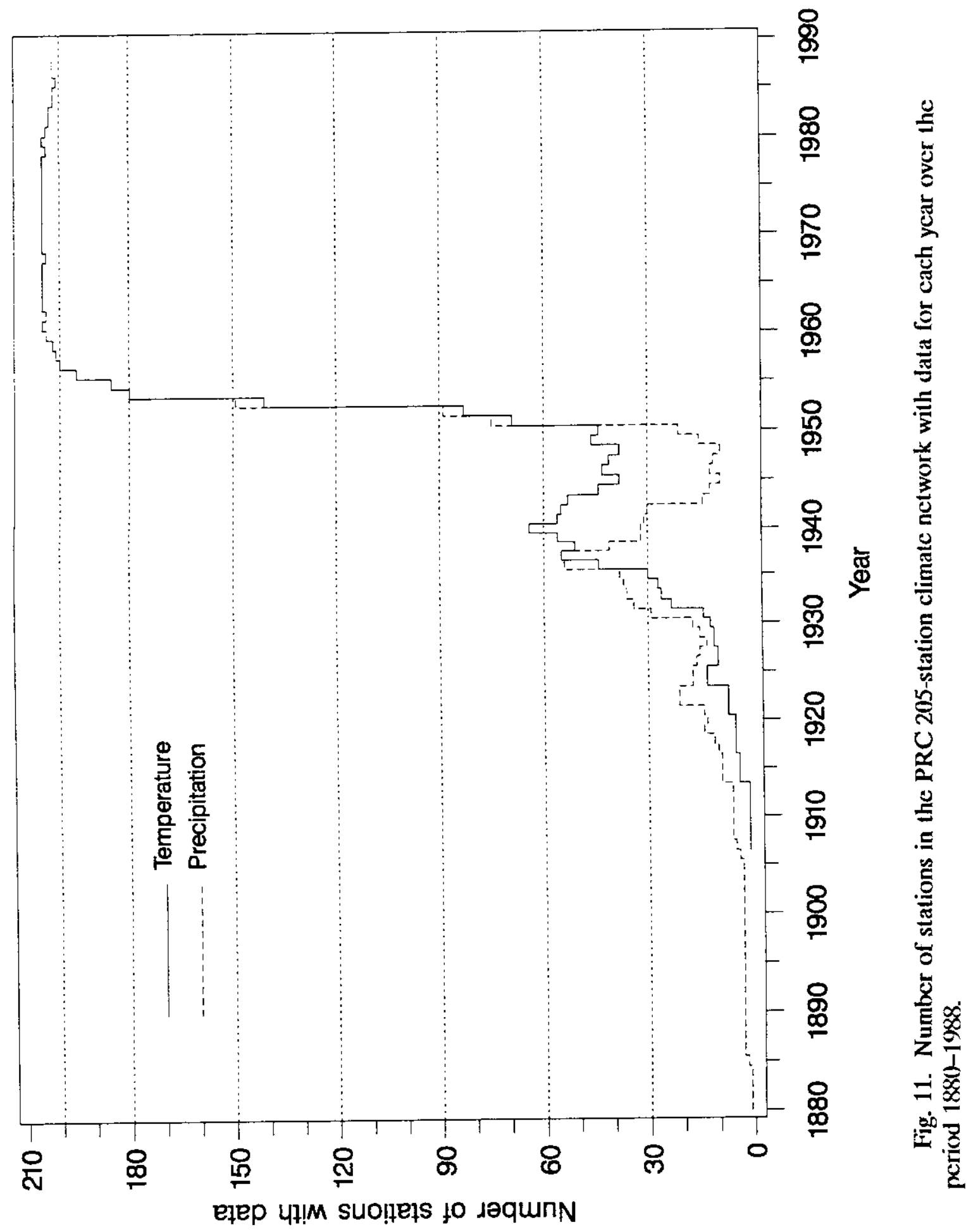




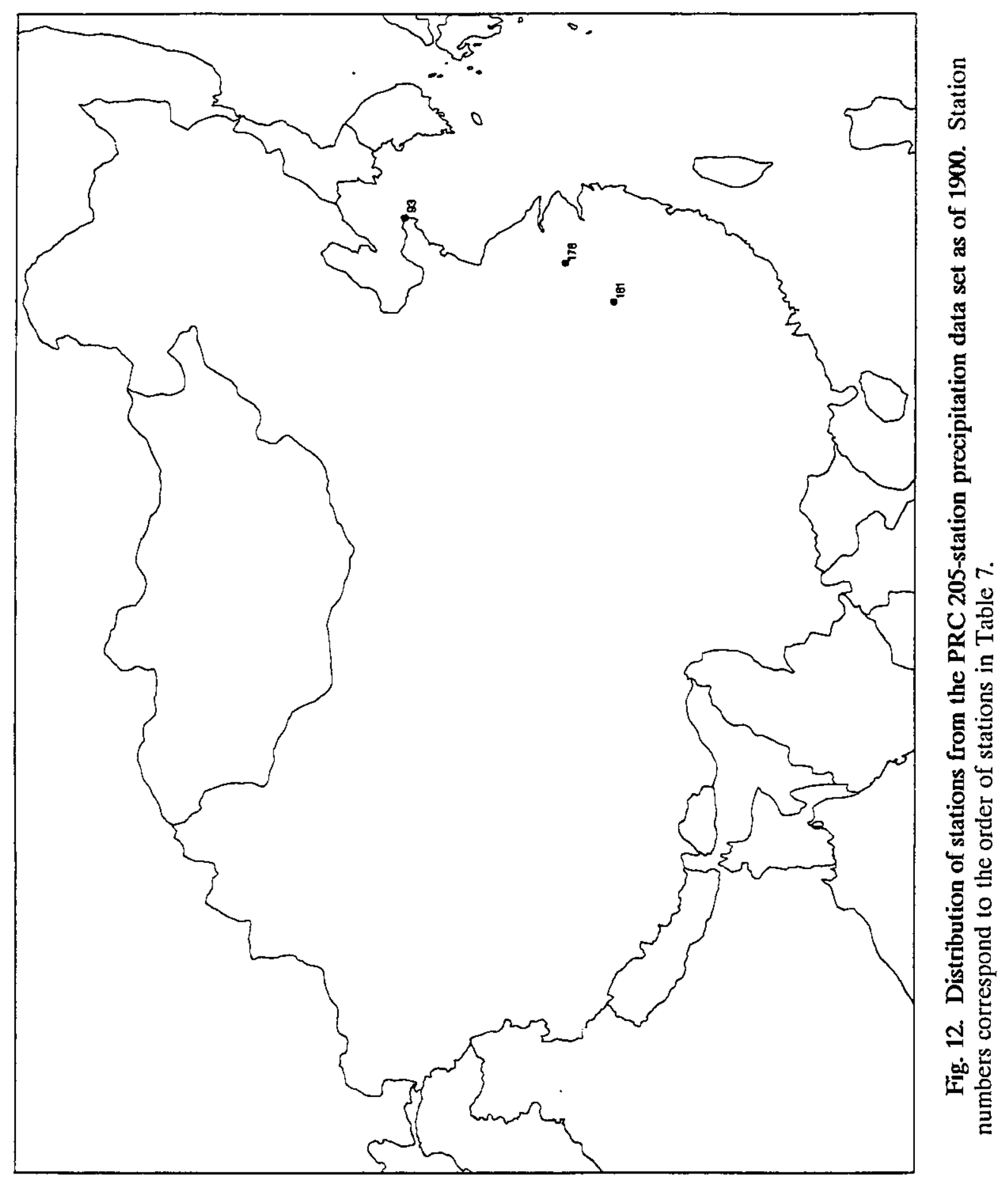




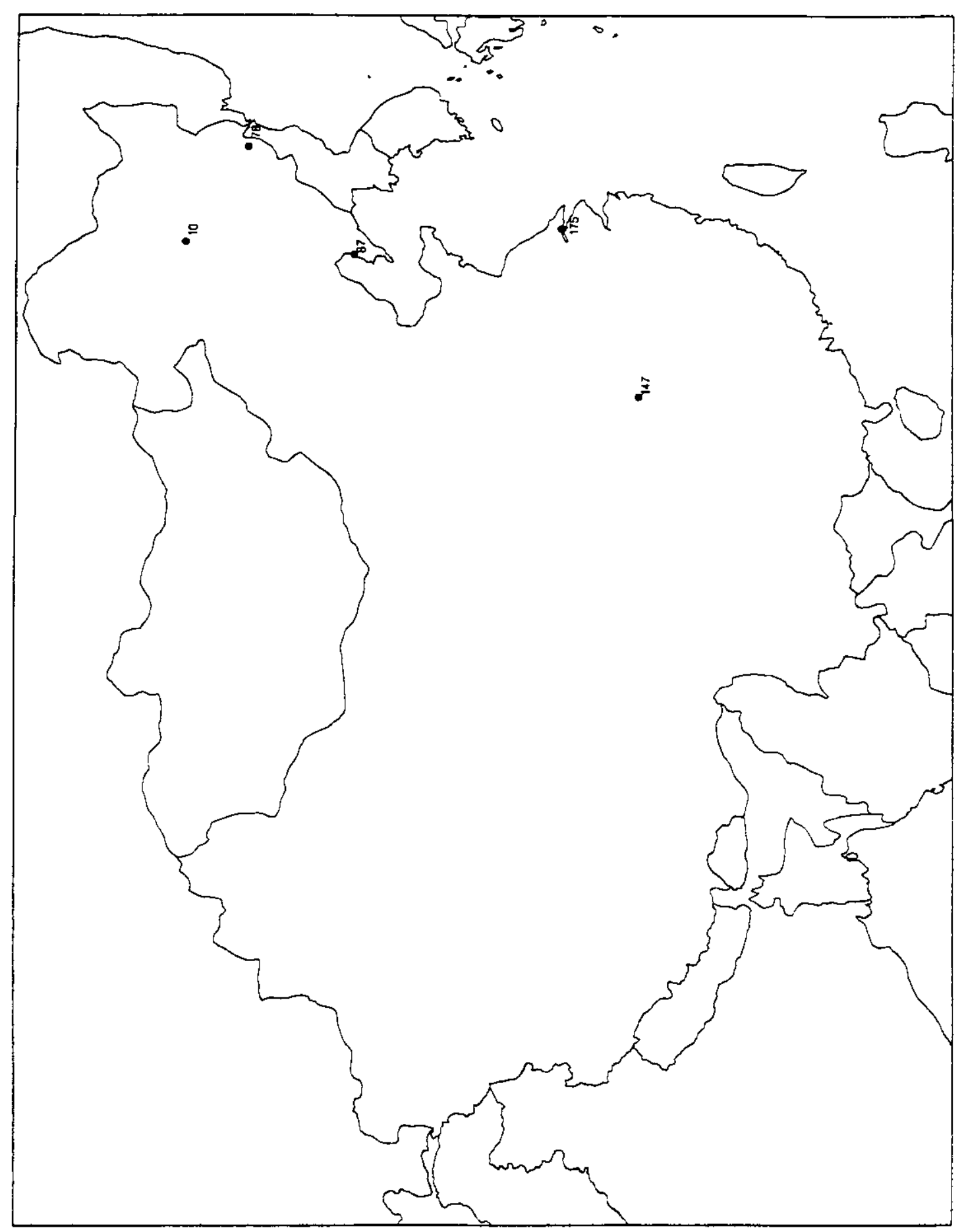

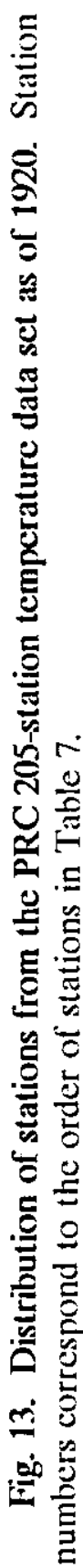




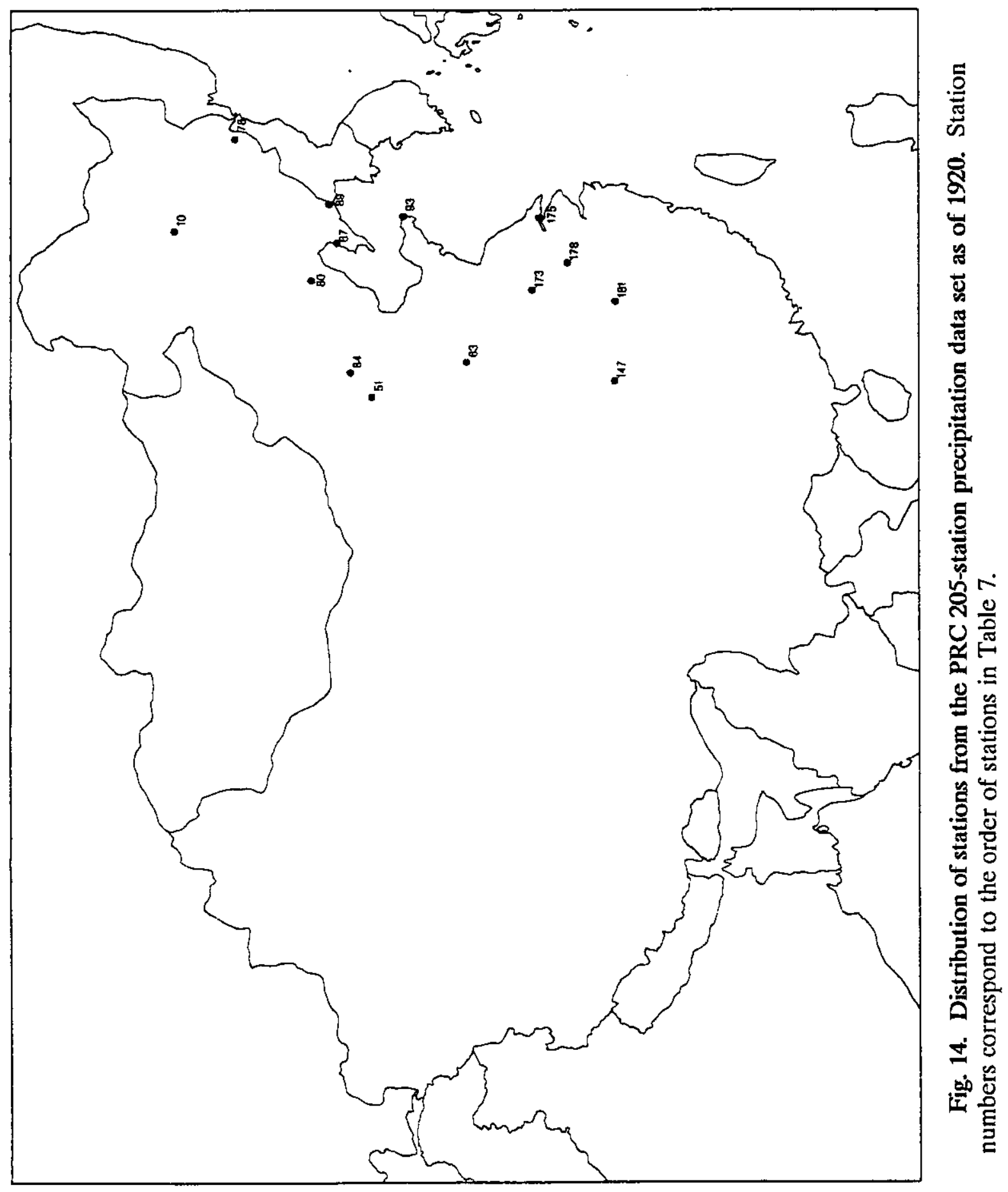




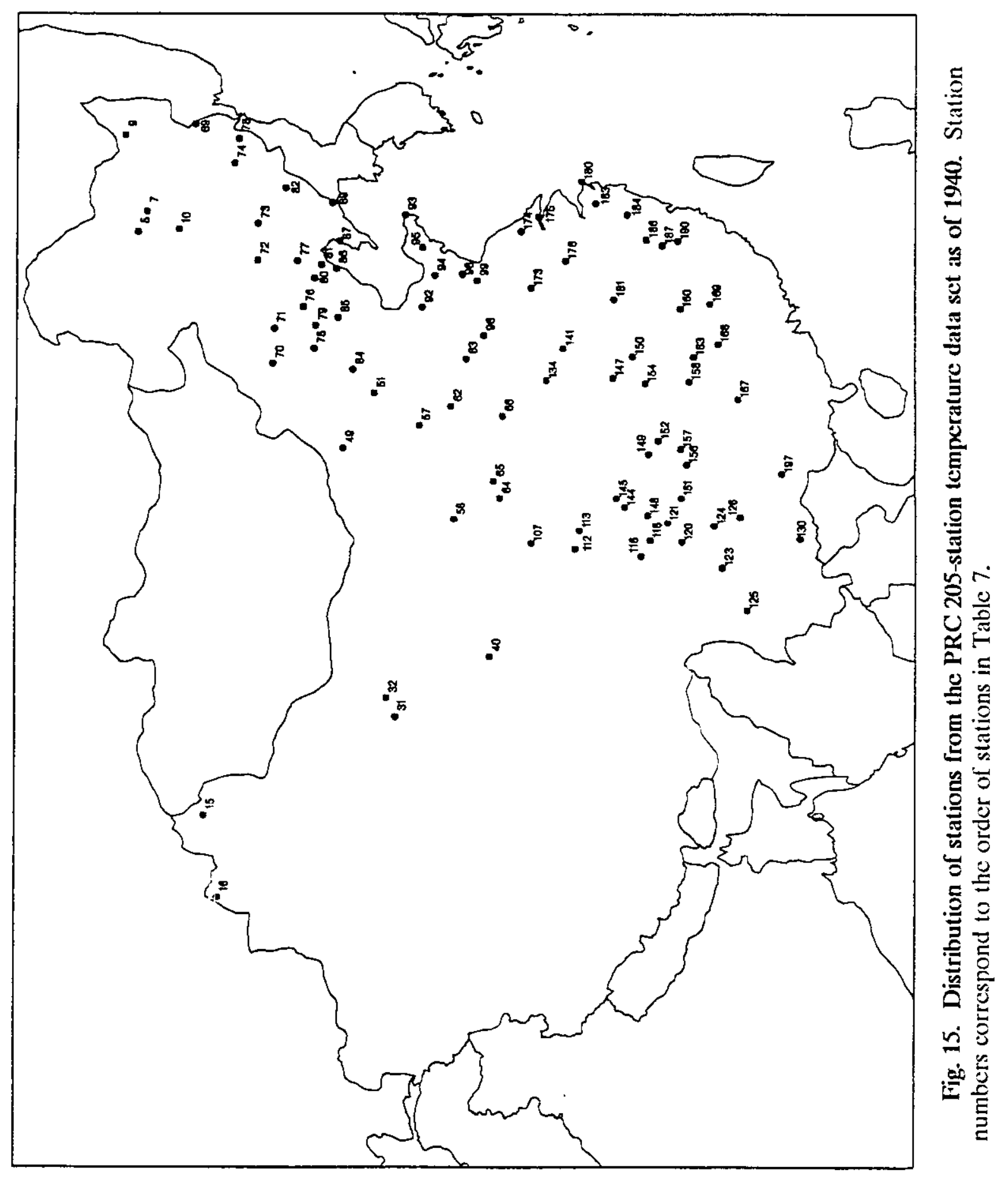




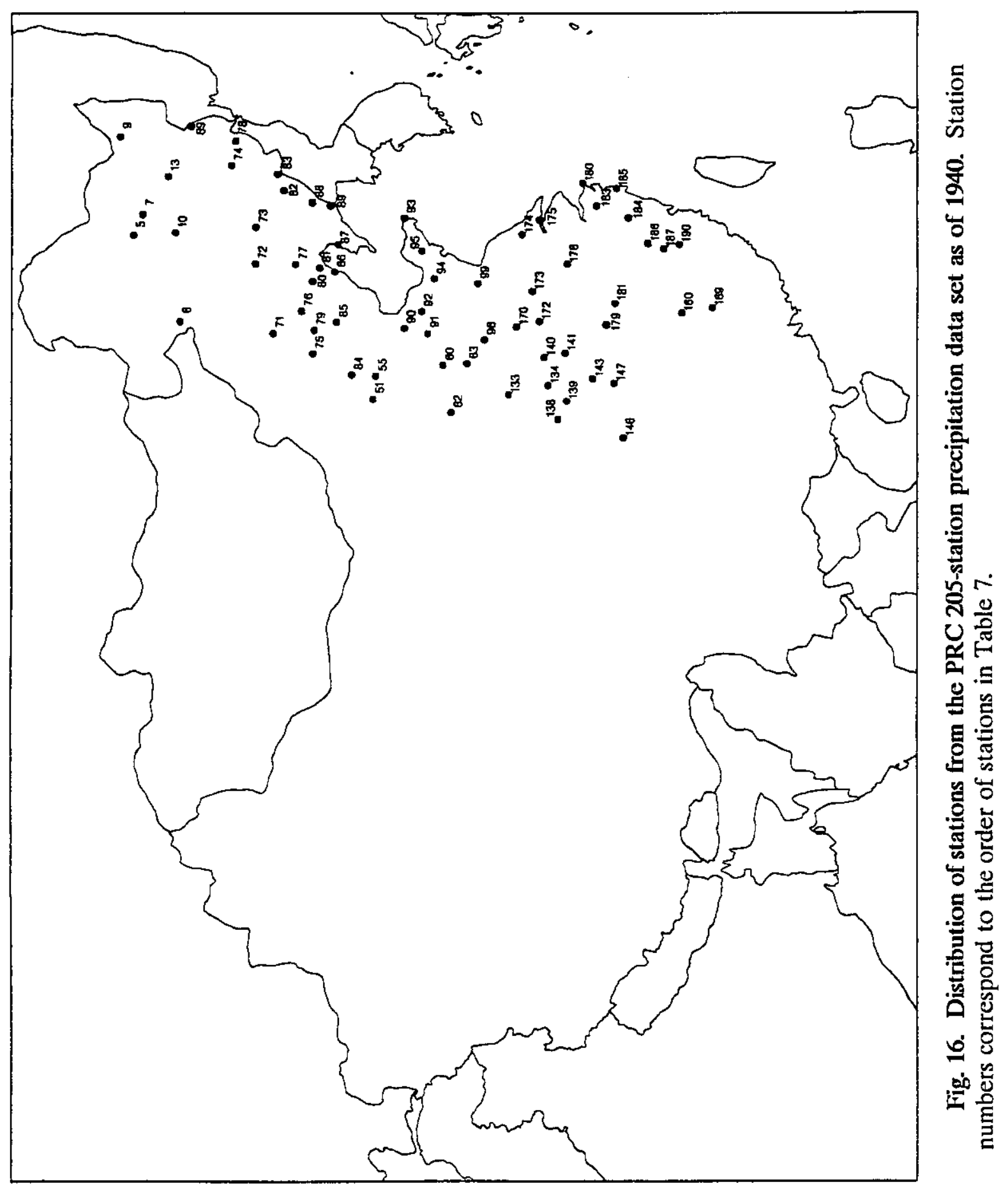




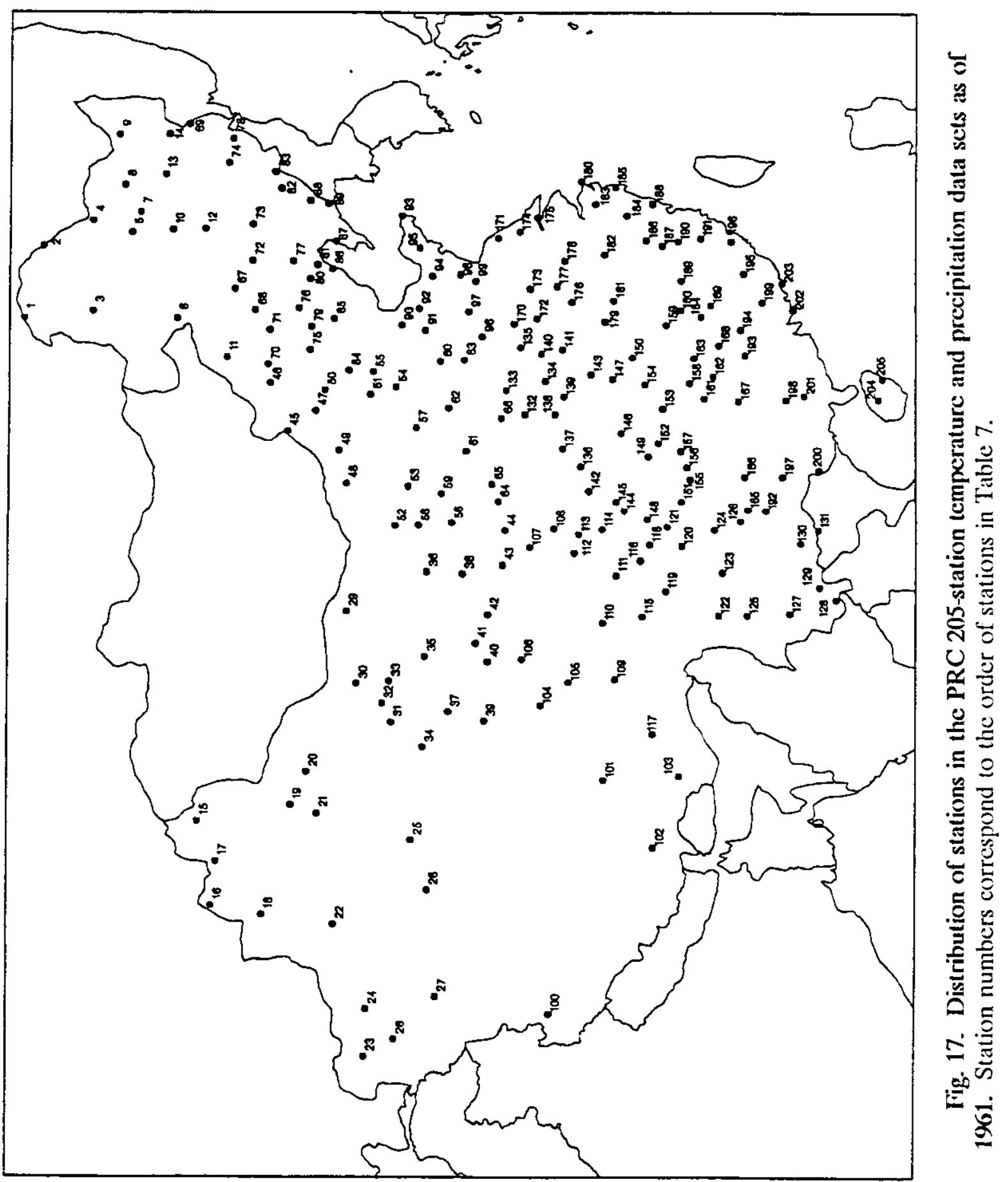




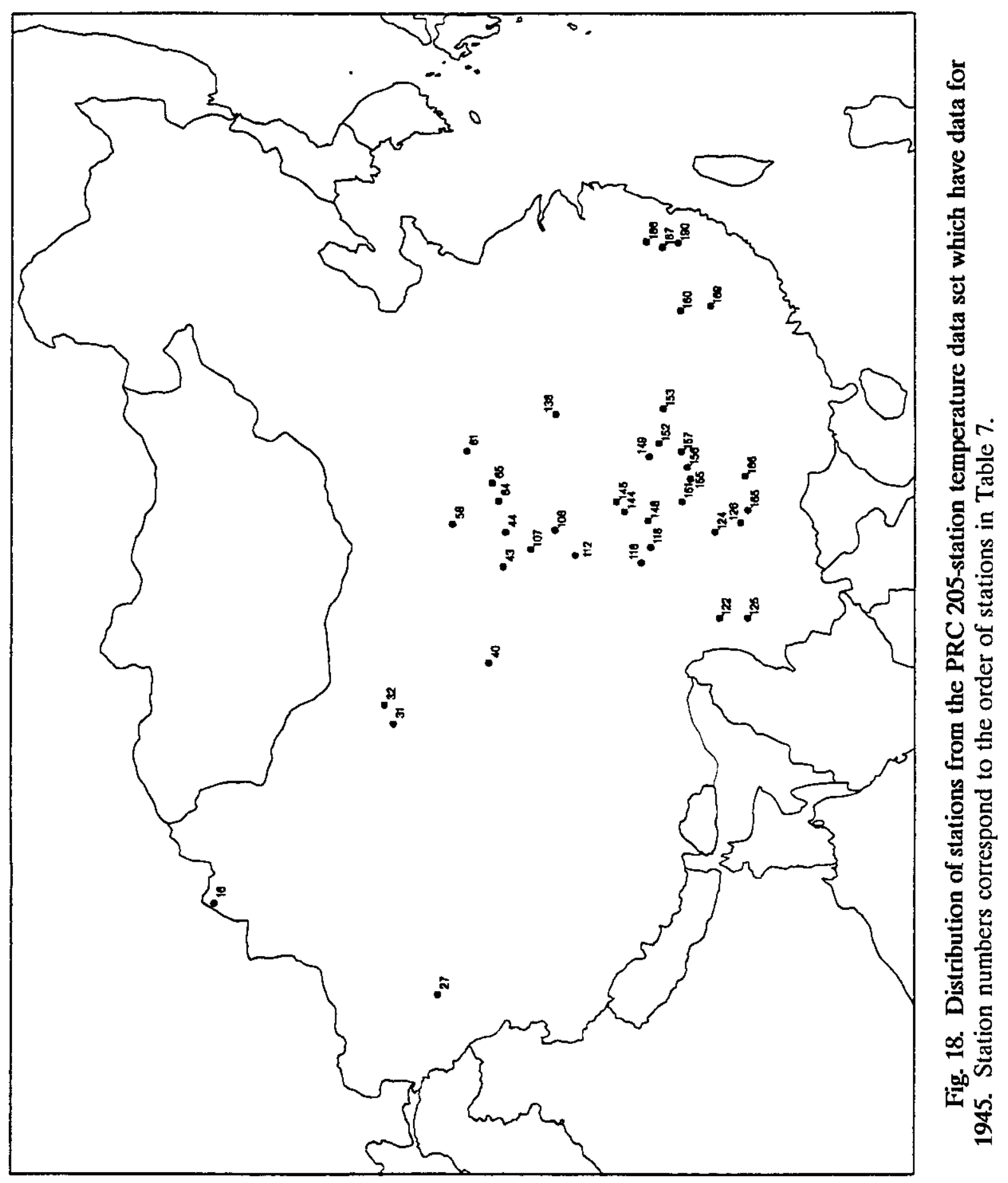




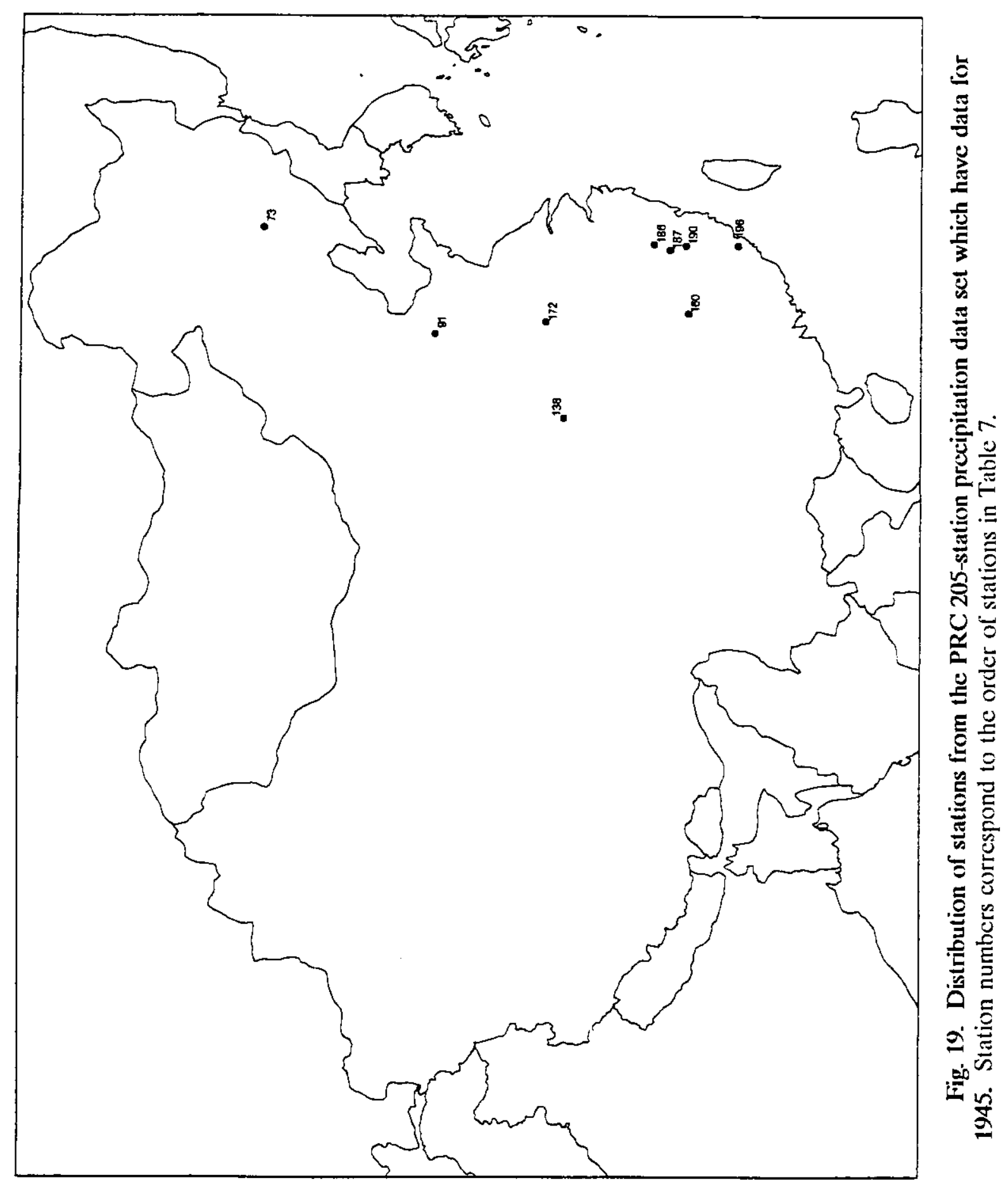




\section{APPLICATIONS OF THE DATA}

Together these data bases represent the most comprehensive, long-term instrumental climate data presently available from the PRC. They may be used for detecting and monitoring long-term climatic changes on a regional scale and in studies attempting to determine the climatic impacts of urbanization and increased atmospheric concentrations of greenhouse gases. The data may also be used by dendrochronologists and paleoclimatologists for calibrating tree ring growth, pollen, and marine plankton data or by those studying impacts of periodic events such as volcanic eruptions or the $\mathrm{El}$ Niño/Southern Oscillation (ENSO). Examples of the latter include the telecoinmunication studies of Diaz and Fu (1987), who examined the correlation between Yangtze River Valley summer precipitation and the ENSO, and Zhang et al. (1987) who analyzed correlations between tropical sea surface temperature and surface land temperatures in China.

The potential uses of the 60-station data set are especially myriad, owing to the many types of relatively long-term data. The temperature, precipitation, sun, cloud, and snow cover data should be especially useful in establishing relationships between regional and large-scale climates.

Analyses of surface pressure and wind fields can play important roles in examining spatial, temporal, and intensity variations of important seasonal climate features affecting China such as the Siberian High and the monsoons of south, southeast, and east Asia. Temperature, precipitation, and relative humidity data should also be valuable in studying these monsoon circulations.

Sunshine duration and cloud amount data are useful in identifying patterns of spatial and temporal variability in each and in understanding past climatic conditions. Karl and Steurer (1990) have illustrated the importance of changes in regional cloudiness to temperature changes and show that increases in cloud amount over the United States since the mid-1950s may help explain its lower rate of temperature increase compared to the rest of the northern hemisphere and the observed decrease in the U.S. average daily temperature range. Sunshine duration measurements are also useful for examining the availability of sunshine and can be used indirectly to determine average insolation. Cloud amount data, when coupled with other cloud parameters, are also useful in verifying and tuning radiative-transfer schemes in climate models.

Monthly data on the number of days with snow cover can be used for studying regional feedbacks between snow cover extent and variables such as temperature, cloud cover, and relative humidity. They could also be used in conjunction with these and other variables to examine the temporal influence of late winter and early spring snow cover extent on the onset of the Asian summer monsoon circulations.

\section{LIMITATIONS AND RESTRICTIONS}

Few station records included in the PRC data sets can be considered truly homogeneous. Even the best stations were subject to minor relocations or changes in observing times, and many have undoubtedly had the effects of urbanization imparted on measures of variables such as temperature (and therefore perhaps number of days with snow cover). Fortunately, for the 60-station network, detailed station histories are available to assist in proper interpretation of trends or jumps in the data. However, examination of these data has uncovered evidence of three undocumented station moves 
(Sects. 8 and 12). Users should therefore exercise caution when using the data. Unfortunately, station histories for the 205-station network are not presently available.

In the interest of timely dissemination of the data, all of the questionable values

found in the data have not been researched. Many have been flagged (Sects. 8 and 12) so that the user may determine how to treat them.

Inhomogeneities may have been created in the sunshine and cloud amount data through the evolution of sunshine recorder instrumentation and cloud measurement procedures. Unfortunately, little documentation is available at this time to confirm exact dates of sunshine recorder changes or give details on methods employed by Chinese observers in their estimation of cloud amount.

\section{QUALITY ASSURANCE OF THE PRC CLIMATE DATA BASES}

An important part of the numeric data package process at CDIAC is the quality assurance (QA) of data before distribution. Data received at CDIAC are rarely in perfect condition for immediate distribution, regardless of the source. To guarantee cata of the highest possible quality, CDIAC conducts extensive QA reviews, which involve examining the data for completeness, reasonableness, and accuracy. Although these reviews have common objectives, they are tailored to each data set, often requiring extensive programming efforts. Although time-consuming, the QA process is an important component in the value-added concept of assuring accurate, usable data for researchers.

Given the large amount and many types of data contained in the PRC data sets as a whole, it is not surprising that CDIAC has found some erroneous and inconsistent values in the data files. Many of these problems were resolved with the help of CAS, but in the interest of timely dissemination of the data, any remaining questionable data are flagged so users may treat these data as they see fit. Flag codes for the data and their definitions are provided in Sect. 12. Descriptions of the QA reviews performed for each of the PRC data sets are presented in the following sections.

\section{0-STATION NETWORK}

The data from these stations were provided by CAS as two files; one with data extending through 1983, the other with data over the period 1984-1988. The latter data set, in addition to the twelve variables found in the former (Sects. 5 and 12), contained values of monthly extreme maximum and minimum temperature. These two data sets were interleaved according to station number, and the missing indicator "-9999" was inserted in the record position of extreme maximum and minimum temperature for years through 1983. The resulting data set was then examined thoroughly using computer software routines developed to check for (1) trends or jumps in the data not explained by seasonal cycles or documented station moves; (2) statistical outliers; (3) identical, non-zero values reported over consecutive months for variables such as total precipitation and sunshine duration; (4) proper relationships between monthly temperature variables; and (5) impossible values (e.g., number of days with snow cover exceeding the number of days in a particular month). The results of the QA checks (by data type), along with a brief assessment of station histories for the 60 stations, are given in the following sections. 


\section{Station Histories}

These histories (Appendix B) contain much of the information needed to determine if a particular station's data can be used confidently by researchers in their assessments of regional and/or large-scale climate change. References to data sources (Appendix C) are provided, as is information regarding station locations (e.g., city, suburb, or countryside, and elevation), station moves, and observing times. However, some potentially useful station-specific details are not present. For example, the switch from the Jordan Photographic Sunshine recorder to the Campbell-Stokes Sunshine recorder, noted in Appendix A as occurring in 1954, may not have taken place at all stations simultaneously as implied. Sunshine recorder changes took many years to implement over the entire U.S. sunshine recording network (Steurer and Karl 1991).

Users should be aware that histories for all stations extend only through 1983. Updates will hopefully be available at a future date. Also, it was found that for three stations $(53463,58367$, and 58633), the data record begins before the period documented by the station history. For three other stations (50745, 54527, and 56294), data is not available until several years after the first year documented in the station histories. Finally, barometric pressure data suggest that three station histories (for stations 57127, 57461 , and 57516) lack documentation of station moves (discussed in the following section).

\section{Monthly Mean Barometric Pressure}

The data seem to show an occasional departure from reporting values to the nearest tenth of a millibar, as evidenced by occurrences of several (in one case, six) consecutive monthly values containing a zero in the tenths place.

Software designed to find deviations from the otherwise characteristic seasonal cycle of monthly mean barometric pressure observed at all 60 stations uncovered evidence of undocumented station moves at stations 57127,57461 , and 57516 , each one having one or more years of pressure data with a markedly different range as compared to prior or subsequent years. Other single-month values which departed significantly from typical seasonal trends were flagged if not corroborated by neighboring stations.

\section{Temperature}

Checks for proper relationships between the various monthly mean/extreme temperatures have been made, and the relatively small number of errors found have been corrected through consultation with CAS.

Another simple check involved looking for statistical outliers by calculating the mean and standard deviation of the respective monthly values for all temperature variables from each station. Values lying 3.5 or more standard deviations away from the mean of the respective monthly values were flagged if not corroborated by temperatures at neighboring stations. Checking for departures from the characteristic seasonal cycle of monthly mean temperature produced several values that, while not statistical outliers, were also flagged as suspect if they could not be corroborated by monthly temperature trends from neighboring stations. The user is referred to the discussion of flag codes for the 60 -station data set in Sect. 12 for additional details. 


\section{Total Precipitation}

QA checks basically focused on flagging very high totals and non-zero repeated totals. Totals exceeding $500 \mathrm{~mm}(\sim 20$ in.) were found in 176 cases, and three of these totals exceeded $1 \mathrm{~m}$. Practically all of these totals were considered valid; they were received in the warmer half of the year in regions that typically experience monsoonal effects. However, the extremely high totals found in the original CAS data set for LaSa (No. 55591) for May-September of 1936 (486.5, 517.7, 2049.6, 1313.2, and 619.2 mm, respectively) were considered suspect and replaced by totals for LaSa obtained from Eischeid et al. (1991). These totals are flagged in the file included with this package and are 48.5, 52.7, 205.0, 131.0, and $62.0 \mathrm{~mm}$ for May-September, respectively. Several high totals for other stations, while not edited, were also flagged, as were several non-zero identical totals over consecutive months (Sect. 12).

\section{Sunshine Duration}

These data were checked for identical values over consecutive months. This type of occurrence should be relatively rare since the monthly totals are rounded to the nearest tenth of an hour. Forty-nine pairs of months were found where this did occur. These values have been flagged (Sect. 12) so users may decide if they appear plausible (perhaps by considering cloud amounts or other data over these months).

Monthly maximum possible sunshine duration was calculated for each station using the station's latitude and assuming a smooth, spherical earth where the sun's rays would not be blocked by natural or man-made obstructions. Using the maximum durations, monthly values of percentage of possible sunshine were calculated for each station and plotted versus corresponding monthly cloud amounts. The plots were examined for obvious outlier data points; ten points being flagged from ten different stations. The sun and cloud values producing these points were examined in the context of the range of sun and cloud data for the particular month and station so as to determine which value was spurious. These values were then set to the missing indicator "-9999". Documentation provided by CAS (Appendix A) points out that a significant number of estimates (not identified) are included in these data.

\section{Monthly Mean Cloud Amount}

These data were simply checked for values $\leq 0$ or $\geq 100 \%$. No values of $0 \%$ were found, but four values of $100 \%$ were found at four different stations. They are considered reasonable in light of the concurrent values of sunshine duration and relative humidity reported at each station. Documentation provided by CAS (Appendix A) points out that a significant number of estimates (not identified) are included in these data.

\section{Monthly Mean Relative Humidity}

These data were simply checked for values $\leq 0$ or $z 100 \%$. None were found; the data appeared reasonable upon cursory inspection. 


\section{Total Number of Days with Snow Cover}

Monthly variations for stations reporting any days with snow cover seem reasonable, and no values exceeding the number of days in a particular month were found.

\section{Monthly Dominant Wind Direction and Dominant Wind Frequency}

Inconsistencies have been found in these data. The dominant wind direction is defined in Appendix A as the most frequent wind direction observed for the month, measured in $22.5^{\circ}$ increments of azimuth clockwise from north. A direction of $0^{\circ}$ is used to denote calm winds, while $360^{\circ}$ indicates a north wind. The data have been checked to make sure all dominant wind directions (if not set to the missing code "-9999") are $0^{\circ}$ or some multiple of $22.5^{\circ}$ up to $360^{\circ}$. Pre-1981 data show a large number of dominant wind directions with values of $0^{\circ}$, the extent of which varies greatly by individual station. This probably makes good physical sense, as diurnal variations alone in many areas could often be associated with lengthy periods of calm at night. However, all dominant wind directions for 1981-1983 are missing, and there are no values of $0^{\circ}$ for any station during the period 1984-1988. This most likely implies a change in the expression of dominant wind direction for the period 1984-1988, while the reason for missing data for 1981-1983 is unknown. Data prior to 1981 have reasonable values for dominant wind frequency, usually ranging from -10 to $50 \%$. Frequencies for 1981-1983 are missing due to missing dominant wind direction, as are those for 1984-1988, even though values of unknown character are present for dominant wind direction. Taking these factors into consideration, the pre-1981 data are considered reasonable, but the nature of these data thereafter is unknown.

\section{Monthly Mean Wind Speed}

These data appear reasonable; values range from 0 to $9.4 \mathrm{~m} / \mathrm{s}$. Only one value of 0 was found (for December 1952 at Yi Ning, No. 51431), and since the dominant wind direction is given as $0^{\circ}(\mathrm{calm})$ the value has not been researched. (The dominant wind frequency is missing for this month).

\section{5-STATION NETWORK}

CAS provided data from these stations as separate temperature and precipitation files. These have been slightly reformatted to allow for the insertion of flags. QA checks and results for each data set are described in the following sections.

\section{Temperature}

Means and standard deviations of each station's respective monthly values were calculated. Values lying 3.5 or more standard deviations away from their respective means were flagged if not corroborated by temperatures at neighboring stations. Checking for departures from the characteristic seasonal cycle of monthly mean temperature produced 
several values that, while not statistical outliers, were deemed suspect if they could not be corroborated by monthly temperature trends from neighboring stations. For additional details of flag codes for the 205-station temperature data set, refer to Sect. 12.

\section{Total Precipitation}

QA checks focused on researching very high totals and flagging non-zero totals repeated over consecutive months. Several hundred totals exceeding $500 \mathrm{~mm}$ are present in the data, with three June totals from Heyuan (No. 59293) exceeding $1 \mathrm{~m}$. These Heyuan totals and several other especially large totals were researched by CAS and confirmed. All of these large amounts were received in the warmer half of the year in regions that typically experience monsoonal effects.

Many instances of identical non-zero totals over consecutive months were found in the data. These have been flagged as described in Sect. 12 for the 205-station precipitation data set.

\section{REFERENCES}

Bradley, R. S., P. M. Kelly, P. D. Jones, C. M. Goodess, and H. F. Diaz. 1985. A climatic data bank for northern hemisphere land areas, 1851-1980. DOE/EV/10739-2. Carbon Dioxide Research Division, U.S. Department of Energy, Washington, D.C.

Diaz, H. F., and Fu Congbin. 1987. Regional precipitation and temperature variability and its relationship to the Southern Oscillation. pp. 213-223. In Y. Duzheng, F. Congbin, C. Jiping, and M. Yoshino (eds.), The Climate of China and Global Climate. China Ocean Press, Beijing.

Eischeid, J. K, H. F. Diaz, R. S. Bradley and P. D. Jones. 1991. A comprehensive precipitation data set for global land areas. DOE/ER-69017T-H1. Carbon Dioxide Research Division, U.S. Department of Energy, Washington, D.C.

Jones, P. D., S. C. B. Raper, B. Santer, B. S. G. Cherry, C. Goodess, P. M. Kelly, T. M. L. Wigley, R. S. Bradley, and H. F. Diaz. 1985. A grid point surface air temperature data set for the northern hemisphere. DOE/EV/10098-2. Carbon Dioxide Research Division, U.S. Department of Energy, Washington, D.C.

Jones, P. D., P. Ya. Groisman, M. Coughlan, N. Plummer, W.-C. Wang, and T. R. Karl. 1990. Assessment of urbanization effects in time series of surface air temperature over land. Nature 347:169-72.

Karl, T. R., and P. M. Steurer. 1990. Increased cloudiness in the United States during the first half of the twentieth century: Fact or fiction? Geophysical Research Letters 17(11):1925-28. 
Koomanoff, F. A, Ye Duzheng, Zhao Jianping, M. R. Riches, W.-C. Wang, and Tao Shiyan. 1988. The United States' Department of Energy and the People's Republic of China's Chinese Academy of Sciences joint research on the greenhouse effect. Bulletin of the American Meteorological Society 69:1301-8.

Marland, G. and R. M. Rotty. 1984. Carbon dioxide emissions from fossil fuels: A procedure for estimation and results for 1950-1982. Tellus 36(B):232-61.

National Environmental Satellite, Data, and Information Service. 1981-1983. World Weather Records, 1961-1970 (Vols. 1-6). U.S. Department of Commerce, Washington, D.C.

Smithsonian Institution. 1927. World Weather Records, -1920. Miscellaneous Collections, Volume 79. Washington, D.C.

Smithsonian Institution. 1934. World Weather Records, 1921-1930. Miscellaneous Collections, Volume 90 . Washington, D.C.

Smithsonian Institution. 1947. World Weather Records, 1931-1940. Miscellaneous Collections, Volume 105. Washington, D.C.

Spangler, W. M. L. and R. L. Jenne. 1990. World Monthly Surface Station Climatology (And Associated Datasets). National Center for Atmospheric Research, Boulder, Colorado.

Steurer, P. M. and T. R. Karl. 1991. Historical sunshine and cloud data in the United States. ORNL/CDIAC-43. Carbon Dioxide Information Analysis Center, Oak Ridge National Laboratory, Oak Ridge, Tennessee.

U.S. Weather Bureau. 1959. World Weather Records, 1941-50 (Vols. 1-6). U.S. Department of Commerce, Washington, D.C.

U.S. Weather Bureau. 1967. World Weather Records, 1951-60 (Vols. 1-6). U.S. Department of Commerce, Washington, D.C.

Wang, W.-C., Z. M. Zeng, and T. R. Karl. 1990. Urban heat islands in China. Geophysical Research Letters 17(12):2377-80.

Zhang, M. L., Zeng Zhaomei, and Pan Yihang. 1987. The connection between the surface air temperature in the northern middle latitudes and the sea surface temperature in the tropical pacific. pp. 202-212. In Y. Duzheng, F. Congbin, C. Jiping, and M. Yoshino (eds.), The Climate of China and Global Climate. China Ocean Press, Beijing. 


\section{HOW TO OBTAIN THE DATA PACKAGE}

The PRC climate data files are available on request on a 9-track magnetic tape from CDIAC. This document and the magnetic tape are available free of charge. Requests for the magnetic tape should include any specific instructions for transmitting the data (e.g., 1600 or 6250 BPI density, labeled or non-labeled, ASCII or EBCDIC characters, and block size or record length constraints) required by the user to access the data. Requests not accompanied by specific instructions will be filled on 9-track, $6250 \mathrm{BPI}$, standardlabeled tapes with characters written in EBCDIC. Requests should be addressed to:

Carbon Dioxide Information Analysis Center

Oak Ridge National Laboratory

Post Office Box 2008

Oak Ridge, Tennessee 37831-6335, U.S.A.

Telephone: (615) 574-0390

FTS 624-0390

Fax: $\quad$ (615) $574-2232$

FTS 624-2232

Electronic Mail: BITNET eMail: CDP@ORNLSTC INTERNET: CDP@STC10.CTD.ORNL.GOV OMNET: CDIAC 
PART 2

INFORMATION ABOUT THE MAGNETIC TAPE 



\section{CONTENTS OF THE MAGNETIC TAPE}

The following is a list of files distributed on magnetic tape by CDIAC along with this documentation.

\begin{tabular}{|c|c|c|c|c|c|c|}
\hline & $\begin{array}{l}\text { File number } \\
\text { and description }\end{array}$ & $\begin{array}{l}\text { File size } \\
\qquad(\mathrm{kB})\end{array}$ & $\begin{array}{l}\text { Logical } \\
\text { records }\end{array}$ & $\begin{array}{l}\text { Record } \\
\text { format }^{a}\end{array}$ & $\begin{array}{l}\text { Block } \\
\text { size }\end{array}$ & $\begin{array}{l}\text { Record } \\
\text { length }\end{array}$ \\
\hline 1. & $\begin{array}{l}\text { General descriptive } \\
\text { information file }\end{array}$ & 84.62 & 656 & FB & 6400 & 128 \\
\hline 2. & $\begin{array}{l}\text { FORTRAN IV data } \\
\text { retrieval code to } \\
\text { read and print the } \\
\text { station inventory from } \\
\text { the } 60 \text {-station data set } \\
\text { (File } 12 \text { ) }\end{array}$ & 2.67 & 33 & FB & 8000 & 80 \\
\hline 3. & $\begin{array}{l}\text { FORTRAN IV data } \\
\text { retrieval code to } \\
\text { read and print the } \\
\text { station inventory from } \\
\text { the } 205 \text {-station data set } \\
\text { (File 13) }\end{array}$ & 2.75 & 34 & FB & 8000 & 80 \\
\hline 4. & $\begin{array}{l}\text { FORTRAN } \Gamma \text { data } \\
\text { retrieval code to } \\
\text { read and print the } \\
60 \text {-station data set } \\
\text { (File } 14 \text { ) }\end{array}$ & 3.08 & 38 & FB & 8000 & 80 \\
\hline 5. & $\begin{array}{l}\text { FORTRAN IV data } \\
\text { retrieval code to } \\
\text { read and print the } \\
\text { 205-station temperature } \\
\text { data set (File 15) }\end{array}$ & 2.59 & 32 & FB & 8000 & 80 \\
\hline 6. & $\begin{array}{l}\text { FORTRAN IV data } \\
\text { retrieval code to } \\
\text { read and print the } \\
\text { 205-station precipitation } \\
\text { data set (File 16) }\end{array}$ & 2.51 & 31 & FB & 8000 & 80 \\
\hline 7. & $\begin{array}{l}\text { SAS }{ }^{b} \text { data retrieval } \\
\text { code to read and } \\
\text { print the station } \\
\text { inventory from the } \\
60 \text {-station data set (File 12) }\end{array}$ & 1.54 & 19 & FB & 8000 & 80 \\
\hline
\end{tabular}




\begin{tabular}{|c|c|c|c|c|c|}
\hline $\begin{array}{l}\text { File number } \\
\text { and description }\end{array}$ & $\begin{array}{l}\text { File size } \\
\qquad(\mathrm{kB})\end{array}$ & $\begin{array}{l}\text { Logical } \\
\text { records }\end{array}$ & $\begin{array}{l}\text { Record } \\
\text { format }^{a}\end{array}$ & $\begin{array}{l}\text { Block } \\
\text { size }\end{array}$ & $\begin{array}{l}\text { Record } \\
\text { length }\end{array}$ \\
\hline $\begin{array}{l}\text { SAS data retrieval } \\
\text { code to read and print } \\
\text { the station inventory } \\
\text { from the } 205 \text {-station } \\
\text { data set (File 13) }\end{array}$ & 1.70 & 21 & FB & 8000 & 80 \\
\hline $\begin{array}{l}\text { SAS data retrieval } \\
\text { code to read and print } \\
\text { the } 60 \text {-station data set } \\
\text { (File 14) }\end{array}$ & 2.10 & 26 & $\mathrm{FB}$ & 8000 & 80 \\
\hline $\begin{array}{l}\text { SAS data retrieval } \\
\text { code to read and print } \\
\text { the } 205 \text {-station temperature } \\
\text { data set (File 15) }\end{array}$ & 1.78 & 22 & $\mathrm{FB}$ & 8000 & 80 \\
\hline $\begin{array}{l}\text { SAS data retrieval } \\
\text { code to read and print } \\
\text { the } 205 \text {-station precipitation } \\
\text { data set (File } 16 \text { ) }\end{array}$ & 1.78 & 22 & $\mathrm{FB}$ & 8000 & so \\
\hline $\begin{array}{l}\text { Station inventory file } \\
\text { for the PRC } 60 \text {-station } \\
\text { climate data set }\end{array}$ & 3.18 & 60 & $\mathrm{FB}$ & 5200 & 52 \\
\hline $\begin{array}{l}\text { Station inventory file } \\
\text { for the PRC } 205 \text { station } \\
\text { temperature and precipitation } \\
\text { data sets }\end{array}$ & 13.74 & 205 & $\mathrm{FB}$ & 6600 & 66 \\
\hline $\begin{array}{l}\text { PRC 60-station } \\
\text { climate data set }\end{array}$ & 6517.21 & 50521 & $\mathrm{FB}$ & 6400 & 128 \\
\hline $\begin{array}{l}\text { PRC } 205 \text { station } \\
\text { temperature data set }\end{array}$ & 1016.21 & 9155 & FB & 8800 & 110 \\
\hline $\begin{array}{l}\text { PRC } 205 \text { station } \\
\text { precipitation data set }\end{array}$ & 1008.55 & 9086 & $\mathrm{FB}$ & 8800 & 110 \\
\hline Total size and records & $\overline{8666.01}$ & $\overline{69,961}$ & & & \\
\hline
\end{tabular}

${ }^{a} \mathrm{FB}=$ fixed block.

${ }^{b}$ SAS is a registered trademark of SAS Institute, Inc., Cary, North Carolina 27511-8000. 


\section{DESCRIPTIVE FILE ON THE MAGNETIC TAPE}

The following is a listing of the first file on the magnetic tape distributed by CDIAC. This file is intended to provide the details (i.e., variable descriptions, formats, and units) of each file associated with this numeric data package.

\section{TITLE OF THE DATA SET}

Two Long-Term Instrumental Climatic Data Bases of the People's Republic of China

\section{DATA CONTRIBUTORS}

Tao Shiyan, Fu Congbin, Zeng Zhaomei, Zhang Qingyun

Institute of Atmospheric Physics

Chinese Academy of Sciences

Beijing, China

\section{SOURCE AND SCOPE OF THE DATA}

Two PRC climate data bases, derived mainly from instrument measurements, are presented in this package; one consists of monthly means, extremes, or totals of 14 meteorological variables observed at 60 stations, the other contains monthly mean temperatures and monthly precipitation totals from 205 stations. The two data bases have no stations in common. Each is described in detail in the following sections.

\section{0-Station Network}

As previously noted, the data from these 60 stations consist of monthly means, extremes, or totals of the following 14 meteorological variables:

- Mean Station Pressure (mb)

- Mean Temperature $\left({ }^{\circ} \mathrm{C}\right)$

- Mean Maximum Temperature $\left({ }^{\circ} \mathrm{C}\right)$

- Mean Minimum Temperature $\left({ }^{\circ} \mathrm{C}\right)$

- Total Precipitation (mm)

- Sunshine Duration (hours)

- Mean Cloud Amount (percentage of sky cover)

- Mean Relative Humidity (percent)

- Snow Days (days with snow cover)

- Dominant Wind Direction (degrees)

- Mean Wind Speed (m/s)

- Dominant Wind Frequency (percent)

- Extreme Maximum Temperature $\left({ }^{\circ} \mathrm{C}\right)$

- Extreme Minimum Temperature $\left({ }^{\circ} \mathrm{C}\right)$ 
Each record contains one month's data; the WMO station number, year, and month, followed by the data variables in the same order as previously listed. Each data value is given in tenths of its specified unit of measure. Missing data values are indicated by "-9999".

Four basic criteria were used in selecting stations to make up the 60-station network: (1) the station should be representative of a particular climate region of China, (2) the station's data should be of relatively high quality, (3) the period of record of the station should be reasonably long, and (4) the resulting station network should have a relatively uniform spatial distribution. Thirteen stations began observing before 1900, Beijing's record is the longest, with temperature and precipitation data dating back to 1841 . All 60 stations have temperature and/or precipitation data available from the beginning of their periods of record, with other types of observations beginning more randomly with time throughout the network. Records from all stations run through 1988, but extreme maximum and minimum temperature data are available for each station only since 1984 . Nearly one-half of the 60 stations have some type of data for at least 70 years, but only six have data for 100 years or more. Data are available from all 60 stations over the period 1951-1988. Periods of whole years without data are omitted from the data set. Station histories are available for these stations and are contained in Appendix B of the document which accompanies this tape.

\section{5-Station Network}

Data from the 205-station network contain two variables: monthly mean temperature and total monthly precipitation. The data are stored in two files, one with temperatures (in tenths of degrees Celsius) and the other with precipitation totals (in tenths of millimeters). Each record of a file contains data from one year: the WMO station number and year followed by twelve monthly data values. Missing values are represented by "-9999". The temperature data date back to 1907 (Jingzhou, No. 57476) and the precipitation data to 1880 (Wuhu, No. 58334). Temperature and precipitation records from 202 stations extend through 1988. Records from Geershiquanhe (No. 55228), Hekou (No. 56989), and Lingling (No. 57866) extend through 1982, 1980, and 1983, respectively. Because of their relatively small number, years without data have been left in these data sets. For both temperature and precipitation data, the most typical length of record ranges between $30-40$ years, with a relatively small share of stations [29 stations $(-15 \%)$ for temperature; 24 stations $(-12 \%)$ for precipitation] having records for 50 or more years. The 60-station data set offers more truly long-term records and, as previously noted, contains temperature and/or precipitation data from the beginning of each station record. The first year for which all 205 stations have temperature and precipitation data is 1961. Unfortunately, station histories are not currently available for any of the stations in the 205-station network; therefore, details regarding instrumentation, collection methods, changes in station location or observing times, and official data sources are not known. 


\section{DATA FORMAT}

The information on this tape is arranged in sixteen files, containing the following:

- this descriptive file

- five FORTRAN IV input/output routines (one per file)

- five $\mathrm{SAS}^{*}$ input/output routines (one per file)

- the station inventory for the PRC 60-station network

- the station inventory for the PRC 205-station network

- the 60-station network climate data set

- the 205-station network temperature data set

- the 205-station network precipitation data set

\section{STATION INVENTORY FILE FOR THE PRC 60-STATION NETWORK CLIMATE DATA SET}

The station inventory file for the 60 -station climate data set (File 12 on the magnetic tape) is sorted by 5-digit station number, with one record per station containing a sequence number (1-60), station name, station number, latitude, longitude, elevation above sea level, and the beginning year of the station's record.

The file may be read using the following FORTRAN format:

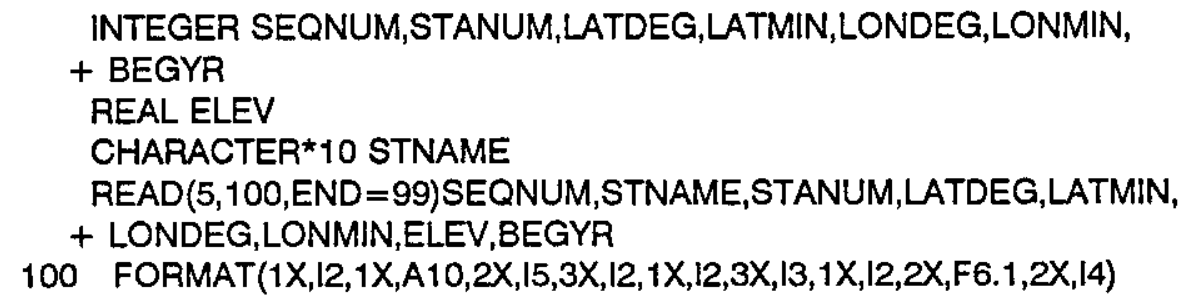

or by using the SAS format:

INPUT SEQNUM 2-3 STNAME \$ 5-14 STANUM 17-21 LATDEG 25-26

LATMIN 28-29 LONDEG 33-35 LONMIN 37-38 ELEV 41-46 BEGYR 49-52

*SAS is a registered trademark of SAS Institute, Inc., Cary, North Carolina 27511-8000. 
Stated in tabular form, the contents include the following.

\begin{tabular}{llccr}
\hline Variable & $\begin{array}{c}\text { Variable } \\
\text { type }\end{array}$ & $\begin{array}{c}\text { Variable } \\
\text { width }\end{array}$ & $\begin{array}{c}\text { Starting } \\
\text { column }\end{array}$ & $\begin{array}{c}\text { Ending } \\
\text { column }\end{array}$ \\
\hline SEQNUM & Numeric & 2 & 2 & 3 \\
STNAME & Character & 10 & 5 & 14 \\
STANUM & Numeric & 5 & 17 & 21 \\
LATDEG & Numeric & 2 & 25 & 26 \\
LATMIN & Numeric & 2 & 28 & 29 \\
LONDEG & Numeric & 3 & 33 & 35 \\
LONMIN & Numeric & 2 & 37 & 46 \\
ELEV & Numeric & 6 & 41 & 52 \\
BEGYR & Numeric & 4 & 49 & \\
\hline
\end{tabular}

where

SEQNUM is the station's relative position in the file $(1-60)$;

STNAME is the name of the station;

STANUM is the WMO station number;

LATDEG is the degrees portion of the station's latitude;

LATMIN is the minutes portion of the station's latitude;

LONDEG is the degrees (east) portion of the station's longitude;

LONMIN is the minutes portion of the station's longitude;

ELEV is the elevation of the station above sea level (m); and

BEGYR is the beginning year of the station's record. 


\section{STATION INVENTORY FILE FOR THE PRC 205-STATION NETWORK TEMPERATURE AND PRECIPITATION DATA SETS}

The station inventory file for the 205-station data sets (File 13 on the magnetic tape) is sorted by 5 -digit station number, with one record per station containing a sequence number (1-205), station name, station number, latitude, longitude, elevation above sea level, and the beginning years of the station's temperature and precipitation records.

The file may be read using the following FORTRAN format:

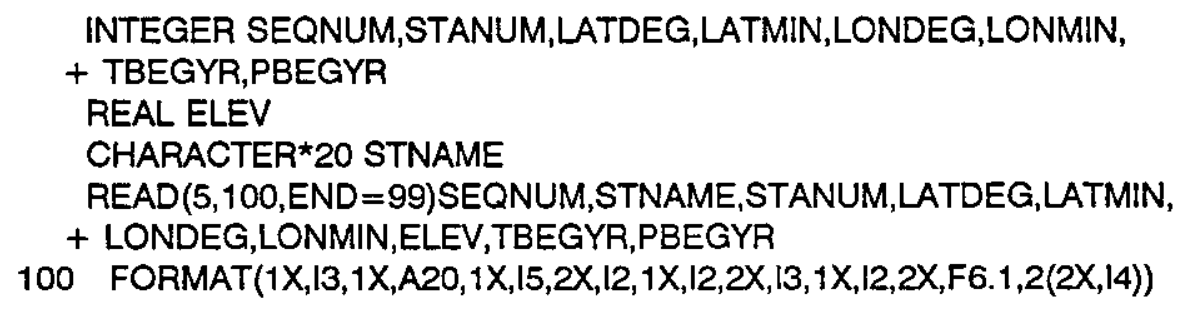

or by using the SAS format:

\section{INPUT SEQNUM 2-4 STNAME \$ 6-25 STANUM 27-31 LATDEG 34-35 \\ LATMIN 37-38 LONDEG 41-43 LONMIN 45-46 ELEV 49-54 TBEGYR 57-60 \\ PBEGYR 63-66}

Stated in tabular form, the contents include the following.

\begin{tabular}{llccc}
\hline Variable & $\begin{array}{l}\text { Variable } \\
\text { type }\end{array}$ & $\begin{array}{c}\text { Variable } \\
\text { width }\end{array}$ & $\begin{array}{c}\text { Starting } \\
\text { column }\end{array}$ & $\begin{array}{r}\text { Ending } \\
\text { column }\end{array}$ \\
\hline SEQNUM & Numeric & 3 & 2 & 4 \\
STNAME & Character & 20 & 6 & 25 \\
STANUM & Numeric & 5 & 27 & 31 \\
LATDEG & Numeric & 2 & 34 & 35 \\
LATMIN & Numeric & 2 & 37 & 38 \\
LONDEG & Numeric & 3 & 41 & 43 \\
LONMIN & Numeric & 2 & 45 & 46 \\
ELEV & Numeric & 6 & 49 & 54 \\
TBEGYR & Numeric & 4 & 57 & 60 \\
PBEGYR & Numeric & 4 & 63 & 66 \\
\hline
\end{tabular}

where

SEQNUM is the station's relative position in the file (1-205); 
STNAME is the name of the station;

STANUM is the WMO station number;

LATDEG is the degrees portion of the station's latitude;

LATMIN is the minutes portion of the station's latitude;

LONDEG is the degrees (east) portion of the station's longitude;

LONMIN is the minutes portion of the station's longitude;

ELEV is the elevation of the station above sea level (m);

TBEGYR is the beginning year of the station's temperature record; and

PBEGYR is the beginning year of the station's precipitation record.

\section{0-STATION NETWORK CLIMATE DATA FILE}

The climate data set from the 60-station network (File 14 on the magnetic tape) contains monthly measurements of 14 climatological variables. The data are sorted by station number, with each record containing data for one month, including station number. year, month, mean station pressure, mean temperature, mean maximum and minimum temperatures, total precipitation, sunshine duration, mean cloud amount, mean relative humidity, total days with snow cover, dominant wind direction, mean wind speed, dominant wind frequency, and extreme maximum and minimum temperatures for the month (1984-1988 only).

The file may be read using the following FORTRAN format:

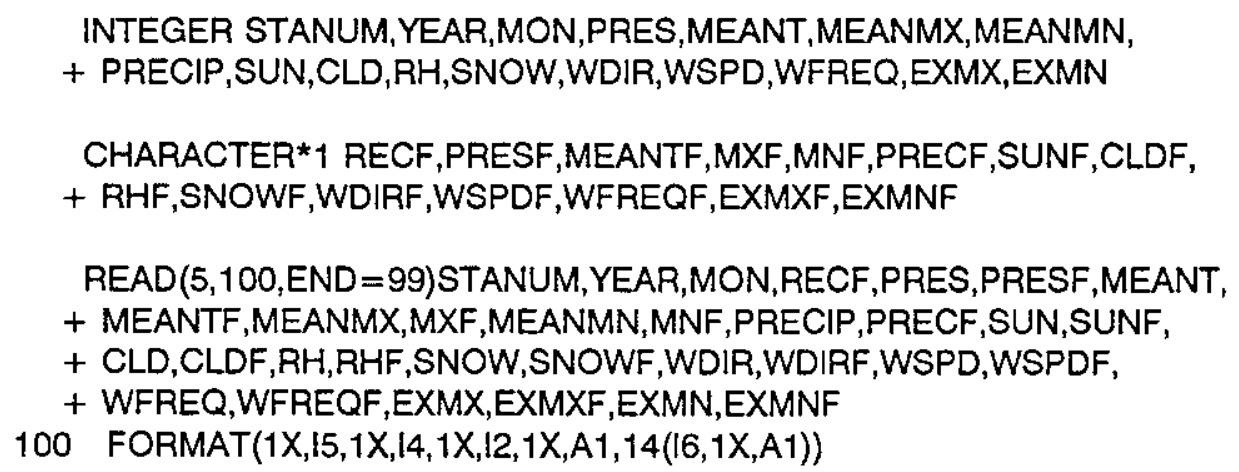


or by using the SAS format:

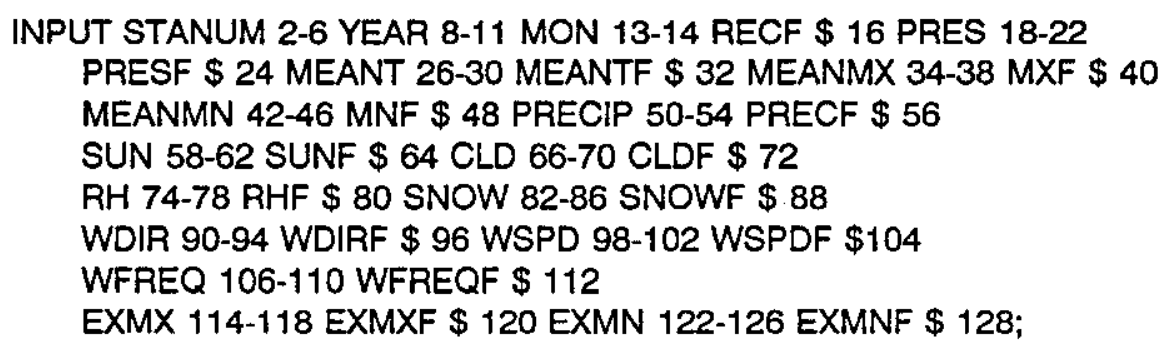

Stated in tabular form, the contents include the following.

\begin{tabular}{|c|c|c|c|c|}
\hline Variable & $\begin{array}{c}\text { Variable } \\
\text { type }\end{array}$ & $\begin{array}{l}\text { Variable } \\
\text { width }\end{array}$ & $\begin{array}{l}\text { Starting } \\
\text { column }\end{array}$ & $\begin{array}{l}\text { Ending } \\
\text { column }\end{array}$ \\
\hline STANUM & Numeric & 5 & 2 & 6 \\
\hline YEAR & Numeric & 4 & 8 & 11 \\
\hline MON & Numeric & 2 & 13 & 14 \\
\hline RECF & Character & 1 & 16 & 16 \\
\hline PRES & Numeric & 5 & 18 & 22 \\
\hline PRESF & Character & 1 & 24 & 24 \\
\hline MEANT & Numeric & 5 & 26 & 30 \\
\hline MEANTF & Character & 1 & 32 & 32 \\
\hline MEANMX & Numeric & 5 & 34 & 38 \\
\hline MXF & Character & 1 & 40 & 40 \\
\hline MEANMN & Numeric & 5 & 42 & 46 \\
\hline MNF & Character & 1 & 48 & 48 \\
\hline PRECIP & Numeric & 5 & 50 & 54 \\
\hline PRECF & Character & 1 & 56 & 56 \\
\hline SUN & Numeric & 5 & 58 & 62 \\
\hline SUNF & Character & 1 & 64 & 64 \\
\hline CLD & Numeric & 5 & 66 & 70 \\
\hline CLDF & Character & 1 & 72 & 72 \\
\hline RH & Numeric & 5 & 74 & 78 \\
\hline RHF & Character & 1 & 80 & 80 \\
\hline SNOW & Numeric & 5 & 82 & 86 \\
\hline SNOWF & Character & 1 & 88 & 88 \\
\hline WDIR & Numeric & 5 & 90 & 94 \\
\hline WDIRF & Character & 1 & 96 & 96 \\
\hline WSPD & Numeric & 5 & 98 & 102 \\
\hline WSPDF & Character & 1 & 104 & 104 \\
\hline WFREQ & Numeric & 5 & 106 & 110 \\
\hline WFREQF & Character & 1 & 112 & 112 \\
\hline
\end{tabular}




\begin{tabular}{lcccc}
\hline Variable & $\begin{array}{c}\text { Variable } \\
\text { type }\end{array}$ & $\begin{array}{c}\text { Variable } \\
\text { width }\end{array}$ & $\begin{array}{c}\text { Starting } \\
\text { column }\end{array}$ & $\begin{array}{c}\text { Ending } \\
\text { column }\end{array}$ \\
\hline EXMX & Numeric & 5 & 114 & 118 \\
EXMXF & Character & 1 & 120 & 120 \\
EXMN & Numeric & 5 & 122 & 126 \\
EXMNF & Character & 1 & 128 & 128 \\
\hline
\end{tabular}

where

STANUM is the WMO station number;

YEAR is the year of the data;

MON is the month of the data;

PRES is the monthly mean station pressure $(\mathrm{mb})$;

MEANT is the monthly mean temperature $\left({ }^{\circ} \mathrm{C}\right)$;

MEANMX is the monthly mean of the daily maximum temperatures $\left({ }^{\circ} \mathrm{C}\right)$;

MEANMN is the monthly mean of the daily minimum temperatures $\left({ }^{\circ} \mathrm{C}\right)$;

PRECIP is the total precipitation (liquid and equivalent liquid of frozen precipitation) for the month (mm);

SUN is the total sunshine duration for the month (hr);

CLD is the mean cloud amount for the month (percent of sky cover);

$\mathrm{RH} \quad$ is the mean relative humidity for the month (percent);

SNOW is the number of days in the month with measurable snow cover;

WDIR is the dominant (most frequent) wind direction observed over the month, measured in $22.5^{\circ}$ increments of azimuth clockwise from north $\left(0^{\circ}\right.$ indicates calm winds, while $360^{\circ}$ indicates a north wind);

WSPD is the mean wind speed for the month $(\mathrm{m} / \mathrm{s})$;

WFREQ is the dominant wind frequency for the month (percent);

EXMX is the extreme maximum temperature observed for the month $\left({ }^{\circ} \mathrm{C}\right)$; and 
EXMN is the extreme minimum temperature observed for the month $\left({ }^{\circ} \mathrm{C}\right)$.

All of the above meteorological variables are expressed in tenths of their specific units of measure.

Flag codes for the data

RECF is a flag denoting if any observations in the record have been corrected using other sources or flagged as being suspect. The following codes indicate which values have been flagged:

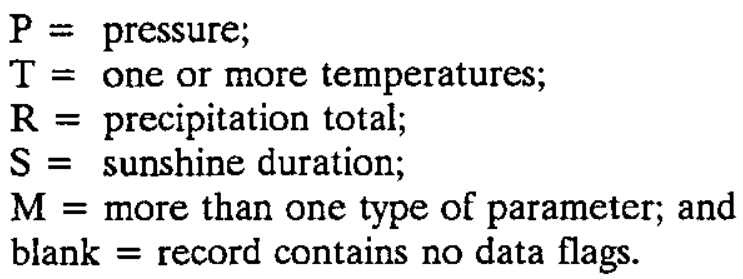

PRESF is the pressure value flag. The codes are as follows:
$\mathrm{T}=$ the pressure departs from general monthly trends; and
$\mathrm{E}=$ pressure values for this year suggest a prior or subsequent change in barometer elevation not noted in the station history.

MEANTF is a flag denoting suspect values of mean monthly temperature. The codes are as follows:
$\mathrm{A}=$ outlier value $;$ not consistent with other reported mean temperature variables for this month;
$\mathrm{B}=$ outlier value; repeated the following month;
$\mathrm{C}=$ outlier value;
$\mathrm{D}=$ value is identical to previous month's value;
$\mathrm{E}=$ value does not fit typical monthly trends and is inconsistent with other reported mean temperature variables for the month;
$\mathrm{F}=$ value is the highest ever reported for this month at this station and is repeated the following month;
$\mathrm{G}=$ value is identical to previous month's value, which has been flagged as being suspect; and
$\mathrm{H}=$ all three mean temperature variables have identical values over May and June of the current year.

\footnotetext{
*Defined as lying 3.5 or more standard deviations away from the mean value of the variable.
} 
$\mathrm{MXF} \quad$ is a flag denoting suspect values of monthly mean maximum temperature. The codes include A, D, E, and $\mathrm{H}$ from the aforementioned MEANTF flag, in addition to the following:

$$
I=\text { outlier value; likely caused by an error in sign. }
$$

MNF is a flag denoting suspect values of monthly mean minimum temperature. The codes are A, D, E, H, and I from the aforementioned MEANTF and MXF flags.

PRECF is the precipitation total flag. The codes are as follow:

$$
\begin{aligned}
\mathrm{R}= & \text { total is identical to the previous or following month's total; } \\
\mathrm{H}= & \text { total is especially high for this station and is considered suspect; } \\
& \text { and; } \\
\mathrm{E}= & \text { original total was considered suspect due to being especially } \\
& \text { high for the station. It has been replaced by data from } \\
& \text { Eischeid et al. (1991). }
\end{aligned}
$$

SUNF is the sunshine duration flag. The code used is:

$$
\mathrm{R}=\text { total is identical to the previous or following month's total. }
$$

The data flags CLDF, RHF, SNOWF, WDIRF, WSPDF, WFREQF, EXMXF, and EXMNF are not used in the current version of the 60-station data set (their storage locations contain only blanks) because, of their associated variables, only the dominant wind direction data contain values of a questionable nature. Pre-1981 data contain a considerable number of dominant wind directions of $0^{\circ}$ (calm winds), whereas data from the period 1984-1988 contain none. (Dominant wind direction data for the period 1981-1983 are missing.)

\section{5-STATION MONTHLY MEAN TEMPERATURE FILE}

The temperature data set from the 205-station network (File 15 on the magnetic tape) contains monthly mean temperatures. The data are sorted by station number, with each record containing data for one year, including station number, year, and mean temperatures for January through December. Temperatures are given in tenths of degrees Celsius.

The file may be read using the following FORTRAN format:

INTEGER STANUM, YEAR, TEMP(12)

CHARACTER *1 RFLAG, TFLAG(12)

READ $(5,100, E N D=99)$ STANUM, YEAR, RFLAG,

+ (TEMP $(I), T F L A G(I), I=1,12)$

100 FORMAT $(2\rfloor 6,1 X, A 1,12(\mid 6,1 X, A 1))$ 
or by using the SAS format:

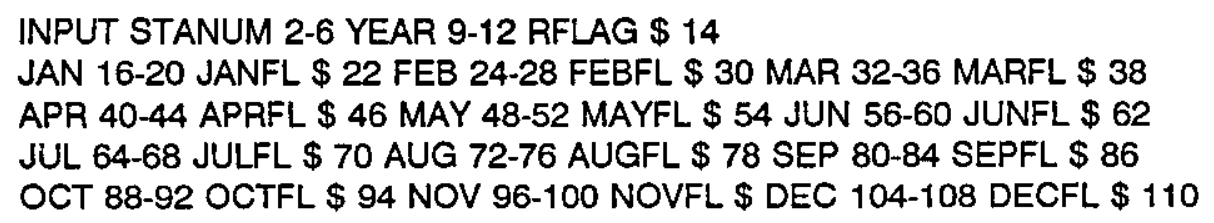

Stated in tabular form, using variable names from the SAS format, the contents include the following.

\begin{tabular}{|c|c|c|c|c|}
\hline Variable & $\begin{array}{c}\text { Variable } \\
\text { type }\end{array}$ & $\begin{array}{c}\text { Variable } \\
\text { width }\end{array}$ & $\begin{array}{l}\text { Starting } \\
\text { column }\end{array}$ & $\begin{array}{l}\text { Ending } \\
\text { column }\end{array}$ \\
\hline STANUM & Numeric & 5 & 2 & 6 \\
\hline YEAR & Numeric & 4 & 9 & 12 \\
\hline RFLAG & Character & 1 & 14 & 14 \\
\hline JAN & Numeric & 5 & 16 & 20 \\
\hline JANFL & Character & 1 & 22 & 22 \\
\hline FEB & Numeric & 5 & 24 & 28 \\
\hline FEBFL & Character & 1 & 30 & 30 \\
\hline MAR & Numeric & 5 & 32 & 36 \\
\hline MARFL & Character & 1 & 38 & 38 \\
\hline APR & Numeric & 5 & 40 & 44 \\
\hline APRFL & Character & 1 & 46 & 46 \\
\hline MAY & Numeric & 5 & 48 & 52 \\
\hline MAYFL & Character & 1 & 54 & 54 \\
\hline JUN & Numeric & 5 & 56 & 60 \\
\hline JUNFL & Character & 1 & 62 & 62 \\
\hline JUL & Numeric & 5 & 64 & 68 \\
\hline JULFL & Character & 1 & 70 & 70 \\
\hline AUG & Numeric & 5 & 72 & 76 \\
\hline AUGFL & Character & 1 & 78 & 78 \\
\hline SEP & Numeric & 5 & 80 & 84 \\
\hline SEPFL & Character & 1 & 86 & 86 \\
\hline $\mathrm{OCT}$ & Numeric & 5 & 88 & 92 \\
\hline OCTFL & Character & 1 & 94 & 94 \\
\hline NOV & Numeric & 5 & 96 & 100 \\
\hline NOVFL & Character & 1 & 102 & 102 \\
\hline $\mathrm{DEC}$ & Numeric & 5 & 104 & 108 \\
\hline DECFL & Character & 1 & 110 & 110 \\
\hline
\end{tabular}


where

STANUM is the WMO station number;

YEAR is the year of the data; and

JAN-DEC are the monthly mean temperatures, given in tenths of degrees Celsius.

Flag codes for the data

RFLAG is a flag denoting whether any observations in the record are considered suspect and/or have been flagged. The codes are as follows:

$X=$ one or more temperatures have been flagged;

$\mathrm{Z}=$ the record is not recommended for use due to a spurious series of at least three consecutive monthly values; and

blank $=$ the record contains no data flags.

JANFL-DECFL are flags denoting suspect temperature values. The codes are as follows:
$A=$ outlier value ${ }^{*}$; departs from typical monthly trends;
$\mathrm{B}=$ outlier value; likely caused by an error in sign;
$\mathrm{C}=$ outlier value; repeated the following month;
$\mathrm{D}=$ outlier value; identical to previous month's value;
$\mathrm{E}=$ outlier value;
$\mathrm{F}=$ value is identical to the previous month's value;
$\mathrm{G}=$ this station (No. 54852) shows identical July and August temperatures over the period 1973-1975;
$\mathrm{H}=$ this station (No. 57411) shows two pairs of repeated temperatures over the period May-August 1969. The values are not statistical outliers, but their pattern makes them suspect; and
$I=$ this station (No. 58734) has repeated temperatures for October-December 1945; the December value is an outlier.

\section{5-STATION PRECIPITATION FILE}

The precipitation data set from the 205-station network (File 16 on the magnetic tape) contains monthly precipitation totals. The data are sorted by station number, with each record containing data for one year, including station number, year, and precipitation totals for January-December (in tenths of millimeters). 
The file may be read using the following FORTRAN format:

INTEGER STANUM,YEAR,P(12)

CHARACTER ${ }^{*}$ RFLAG, PFLAG(12)

READ $(5,100, E N D=99)$ STANUM, YEAR, RFLAG, (P(I),PFLAG $(l), 1=1,12)$

100 FORMAT(2l6,1X,A1,12(16,1X,A1))

or by using the SAS format:

INPUT STANUM 2-6 YEAR 9-12 RFLAG \$ 14

JAN 16-20 JANFL \$ 22 FEB 24-28 FEBFL \$ 30 MAR 32-36 MARFL \$ 38

APR 40-44 APRFL \$ 46 MAY 48-52 MAYFL \$ 54 JUN 56-60 JUNFL \$ 62

JUL 64-68 JULFL $\$ 70$ AUG 72-76 AUGFL $\$ 78$ SEP 80-84 SEPFL $\$ 86$

OCT 88-92 OCTFL \$ 94 NOV 96-100 NOVFL \$ DEC 104-108 DECFL \$110

Stated in tabular form, using variable names from the SAS format, the contents include the following.

\begin{tabular}{|c|c|c|c|c|}
\hline Variable & $\begin{array}{c}\text { Variable } \\
\text { type }\end{array}$ & $\begin{array}{c}\text { Variable } \\
\text { width }\end{array}$ & $\begin{array}{l}\text { Starting } \\
\text { column }\end{array}$ & $\begin{array}{l}\text { Ending } \\
\text { column }\end{array}$ \\
\hline STANUM & Numeric & 5 & 2 & 6 \\
\hline YEAR & Numeric & 4 & 9 & 12 \\
\hline RFLAG & Character & 1 & 14 & 14 \\
\hline JAN & Numeric & 5 & 16 & 20 \\
\hline JANFL & Character & 1 & 22 & 22 \\
\hline FEB & Numeric & 5 & 24 & 28 \\
\hline FEBFL & Character & 1 & 30 & 30 \\
\hline MAR & Numeric & 5 & 32 & 36 \\
\hline MARFL & Character & 1 & 38 & 38 \\
\hline APR & Numeric & 5 & 40 & 44 \\
\hline APRFL & Character & 1 & 46 & 46 \\
\hline MAY & Numeric & 5 & 48 & 52 \\
\hline MAYFL & Character & 1 & 54 & 54 \\
\hline JUN & Numeric & 5 & 56 & 60 \\
\hline JUNFL & Character & 1 & 62 & 62 \\
\hline JUL & Numeric & 5 & 64 & 68 \\
\hline JULFL & Character & 1 & 70 & 70 \\
\hline AUG & Numeric & 5 & 72 & 76 \\
\hline AUGFL & Character & 1 & 78 & 78 \\
\hline SEP & Numeric & 5 & 80 & 84 \\
\hline SEPFL & Character & 1 & 86 & 86 \\
\hline $\mathrm{OCT}$ & Numeric & 5 & 88 & 92 \\
\hline OCTFL & Character & 1 & 94 & 94 \\
\hline
\end{tabular}




\begin{tabular}{lcccc}
\hline Variable & $\begin{array}{c}\text { Variable } \\
\text { type }\end{array}$ & $\begin{array}{c}\text { Variable } \\
\text { width }\end{array}$ & $\begin{array}{c}\text { Starting } \\
\text { column }\end{array}$ & $\begin{array}{c}\text { Ending } \\
\text { column }\end{array}$ \\
\hline NOV & Numeric & 5 & 96 & 100 \\
NOVFL & Character & 1 & 102 & 102 \\
DEC & Numeric & 5 & 104 & 108 \\
DECFL & Character & 1 & 110 & 110 \\
\hline
\end{tabular}

where

STANUM is the WMO station number;

YEAR is the year of the data; and

JAN-DEC are the monthly precipitation totals, given in tenths of millimeters.

Flag codes for the data

RFLAG is a flag denoting if any observations in the record have been flagged as being suspect. The codes are as follows:

$\mathrm{X}=$ one or more precipitation totals have been flagged; and blank $=$ the record contains no data flags.

JANFL-DECFL are flags denoting suspect precipitation values. The single code used is:

$\mathrm{R}=$ total is repeated over consecutive months. Totals $\leq 1.0 \mathrm{~mm}$ repeated over two or more consecutive months were not flagged. If all entries in records containing repeated totals contained zeros in their tenths place, the repeated totals were only flagged if they were $\geq 10.0 \mathrm{~mm}$. All non-zero totals repeated over three consecutive months were flagged regardless of magnitude.

\section{REFERENCES}

Eischeid, J. K., H. F. Diaz, R. S. Bradley, and P. D. Jones. 1991. A comprehensive precipitation data set for global land areas. DOE/ER-69017T-H1. Carbon Dioxide Research Division, U.S. Department of Energy, Washington, D.C. 


\section{LISTINGS OF THE FORTRAN IV DATA RETRIEVAL PROGRAMS}

The following is a listing of the FORTRAN IV data retrieval program provided on magnetic tape (File 2 on the tape) by CDIAC for reading and printing the station inventory file for the 60-station data set (File 12 on the tape). The job control language (JCL) statements (preceded by $/ /$ or $/{ }^{*}$ ) shown in the following are not provided in the file on the magnetic tape. The JCL statements required will vary for each operating system. The JCL statements in the following are provided to illustrate the statements required by an individual at ORNL who has requested these data on a nine-track, $6250 \mathrm{BPI}$, standard-labeled tape with characters written in EBCDIC and who is attempting to read the tape on an IBM mainframe (e.g., IBM 3090).

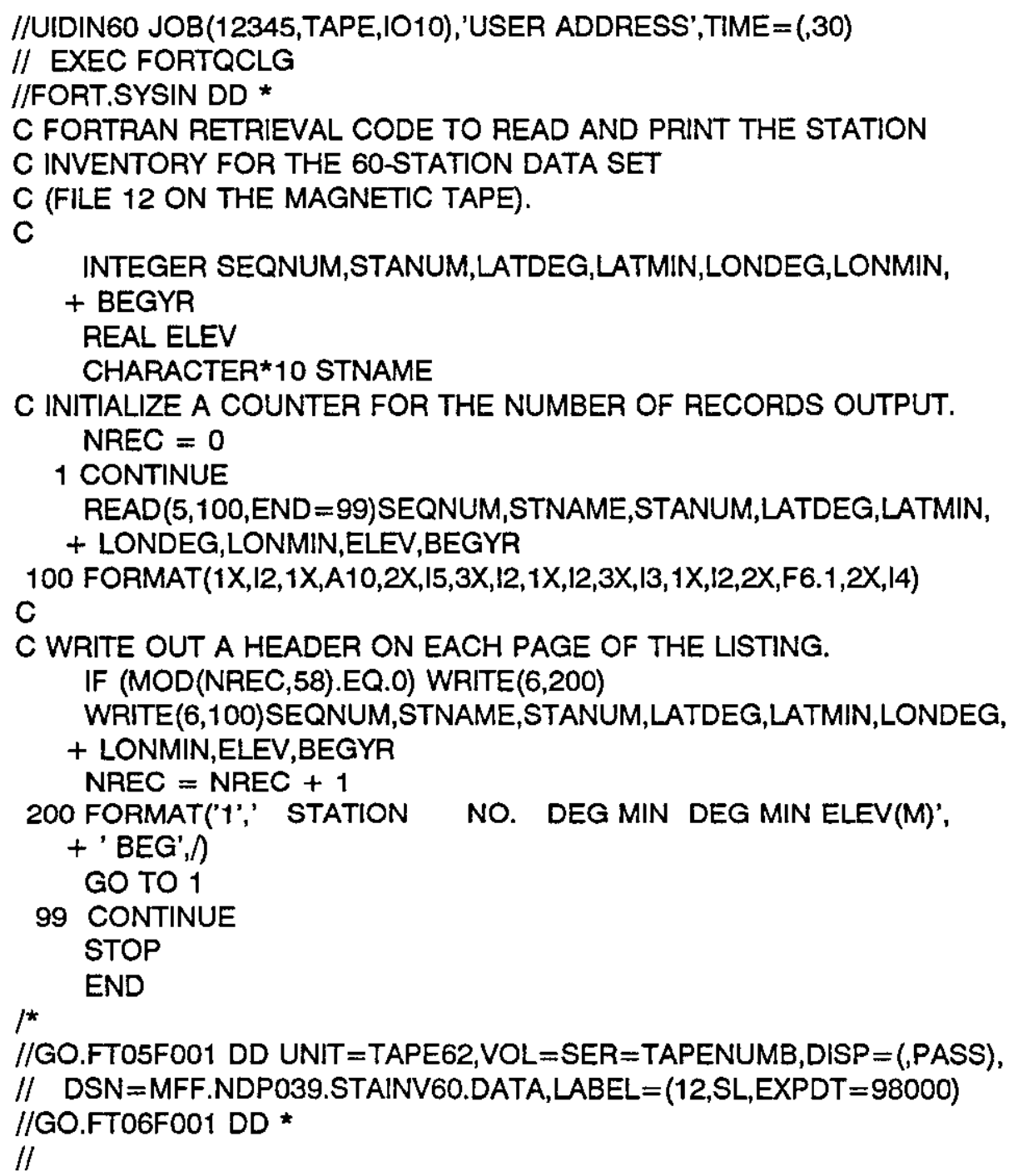


The following is a listing of the FORTRAN IV data retrieval program provided on magnetic tape (File 3 on the tape) by CDIAC for reading and printing the station inventory file for the 205-station data sets (File 13 on the tape). The JCL statements (preceded by $/ /$ or $/^{*}$ ) shown in the following are not provided in the file on the magnetic tape. The JCL statements required will vary for each operating system. The JCL

statements shown in the following are provided to illustrate the statements required by an individual at ORNL who has requested these data on a nine-track, $6250 \mathrm{BPI}$, standardlabeled tape with characters written in EBCDIC and who is attempting to read the tape on an IBM mainframe (e.g., IBM 3090).

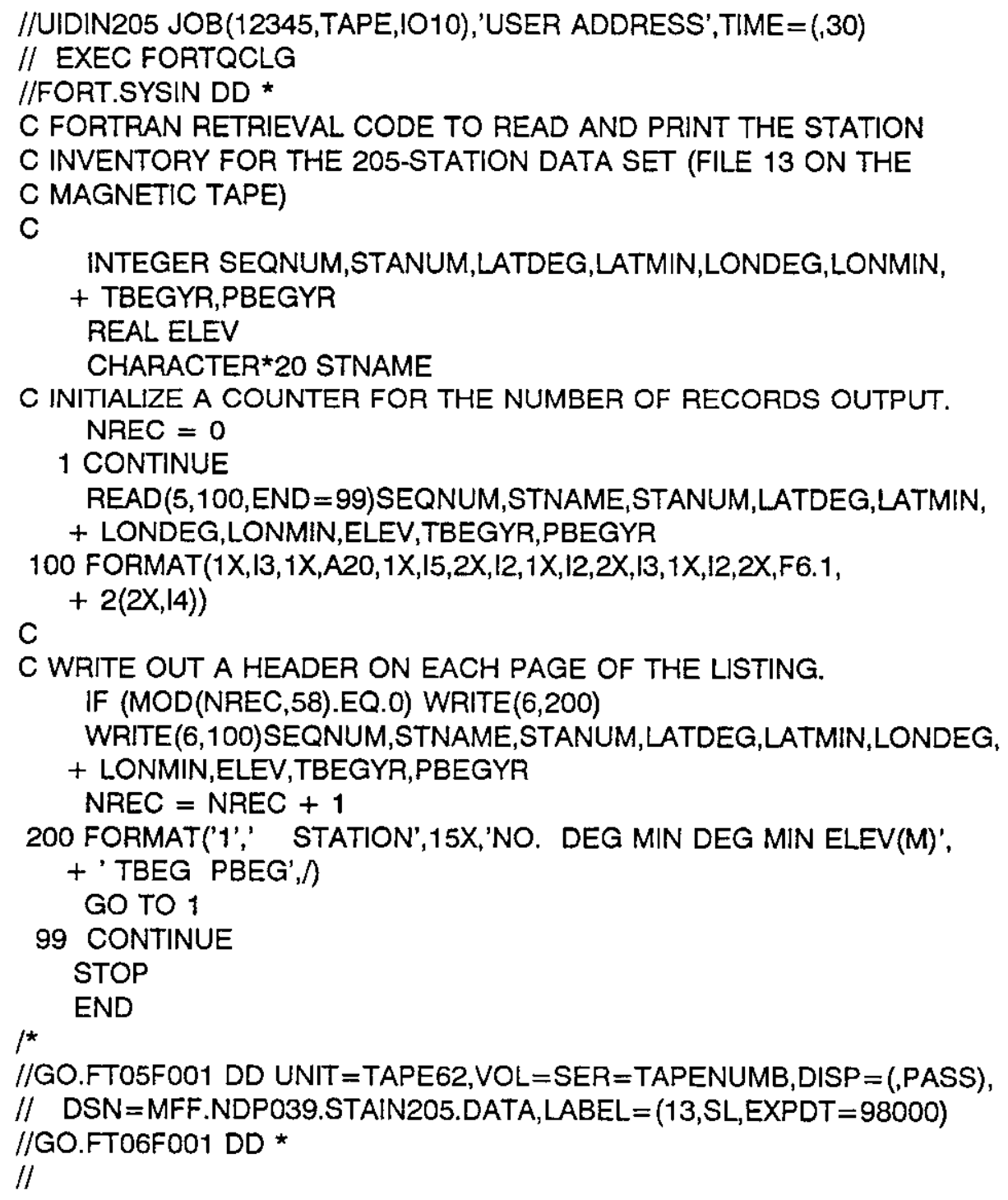


The following is a listing of the FORTRAN IV data retrieval program provided on magnetic tape (File 4 on the tape) by CDIAC for reading and printing the 60 -station climate data file (File 14 on the tape). The JCL statements (preceded by $/ /$ or $/{ }^{*}$ ) shown in the following are not provided in the file on the magnetic tape. The JCL statements required will vary for each operating system. The JCL statements in the following are provided to illustrate the statements required by an individual at ORNL who has requested these data on a nine-track, $6250 \mathrm{BPI}$, standard-labeled tape with characters written in EBCDIC and who is attempting to read the tape on an IBM mainframe (e.g., IBM 3090).

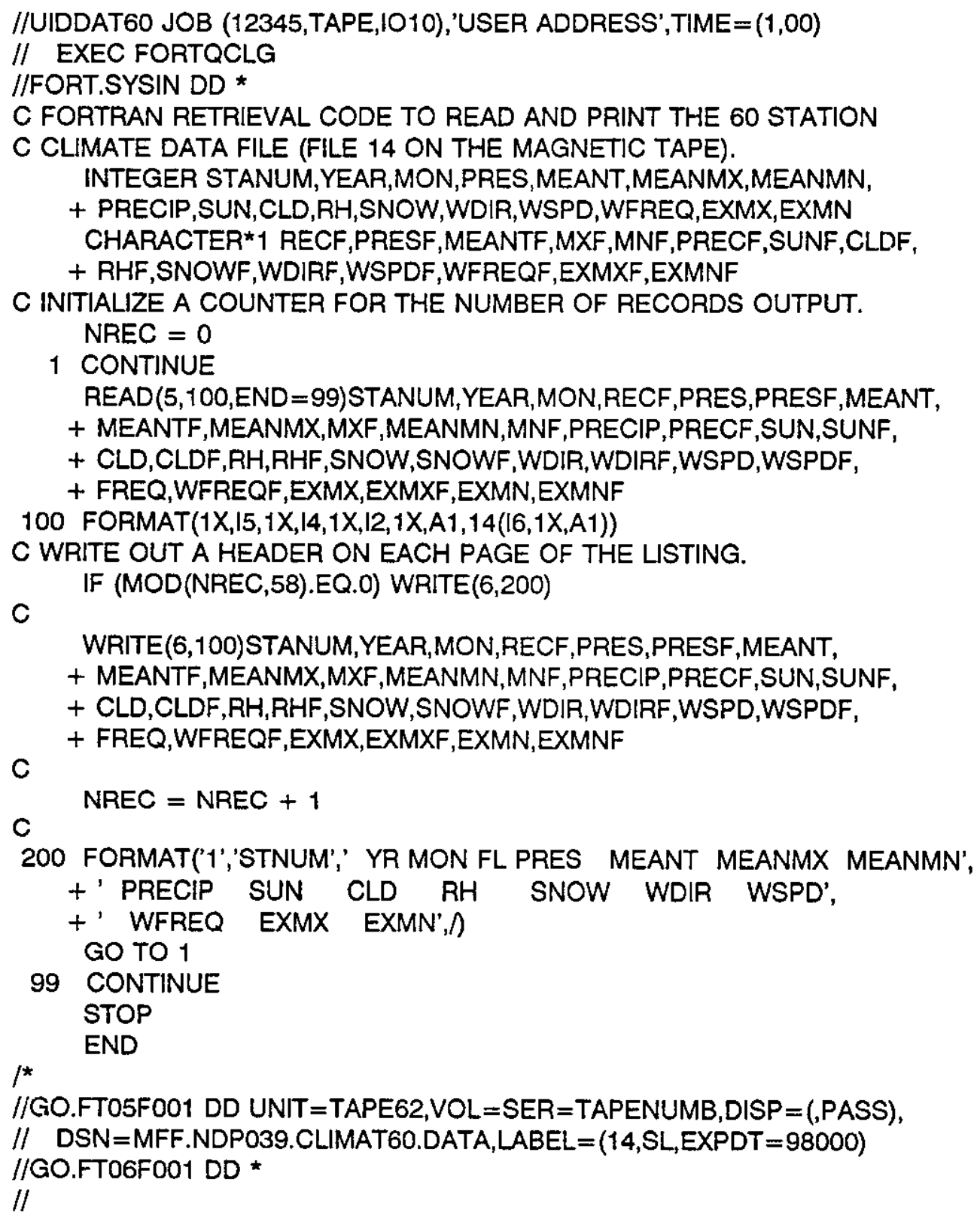


The following is a listing of the FORTRAN IV data retrieval program provided on magnetic tape (File 5 on the tape) by CDIAC for reading and printing the 205-station monthly mean temperature file (File 15 on the tape). The JCL statements (preceded by // or $/^{*}$ ) shown in the following are not provided in the file on the magnetic tape. The JCL statements required will vary for each operating system. The JCL statements shown in the following are provided to illustrate the statements required by an individual at ORNL who has requested these data on a nine-track, $6250 \mathrm{BPI}$, standard-labeled tape with characters written in EBCDIC and who is attempting to read the tape on an IBM mainframe (e.g., IBM 3090).

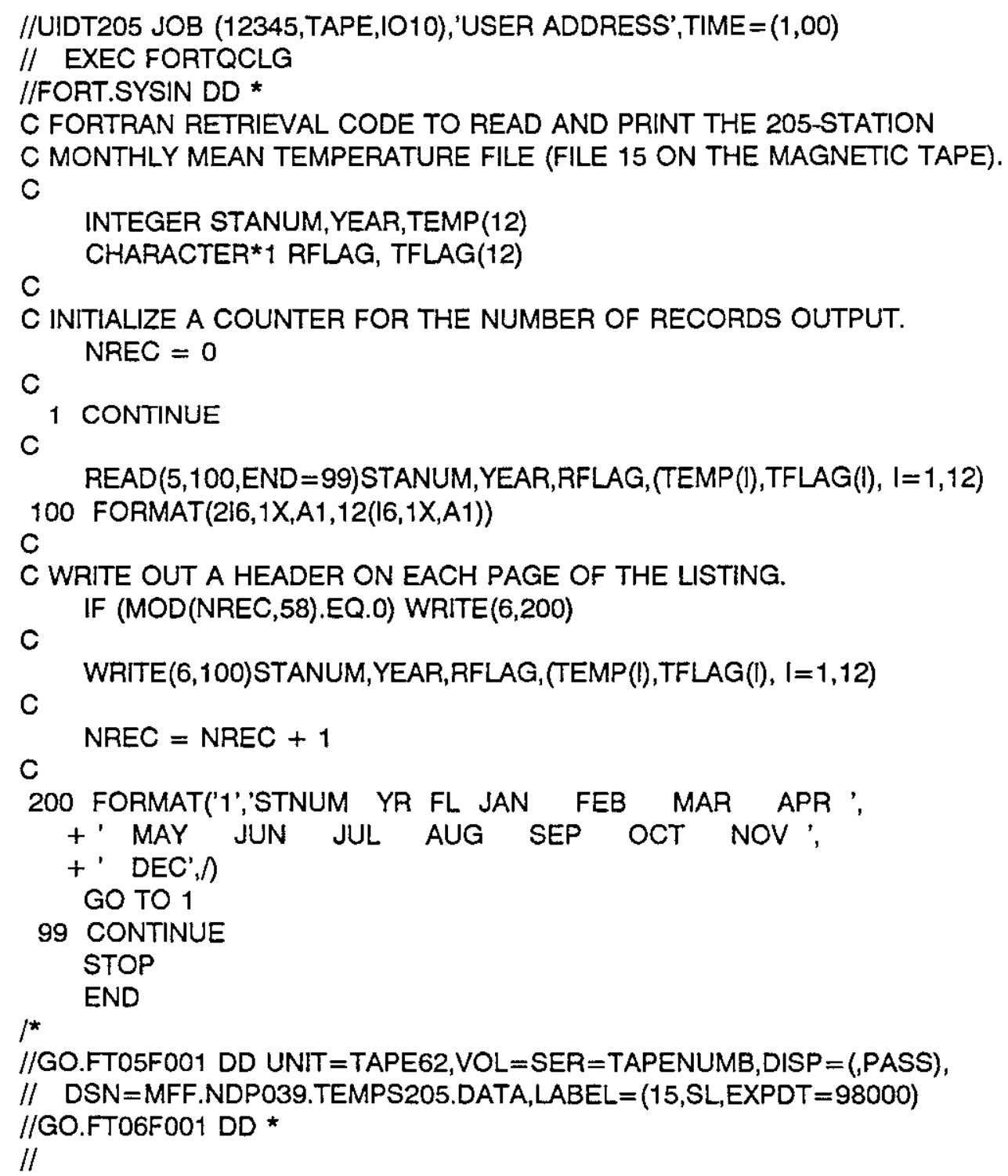


The following is a listing of the FORTRAN IV data retrieval program provided on magnetic tape (File 6 on the tape) by CDIAC for reading and printing the 205-station monthly precipitation file (File 16 on the tape). The JCL statements (preceded by // or $\left./^{*}\right)$ shown in the following are not provided in the file on the magnetic tape. The JCL statements required will vary for each operating system. The JCL statements shown in the following are provided to illustrate the statements required by an individual at ORNL who has requested these data on a nine-track, $6250 \mathrm{BPI}$, standard-labeled tape with characters written in EBCDIC and who is attempting to read the tape on an IBM mainframe (e.g., IBM 3090).

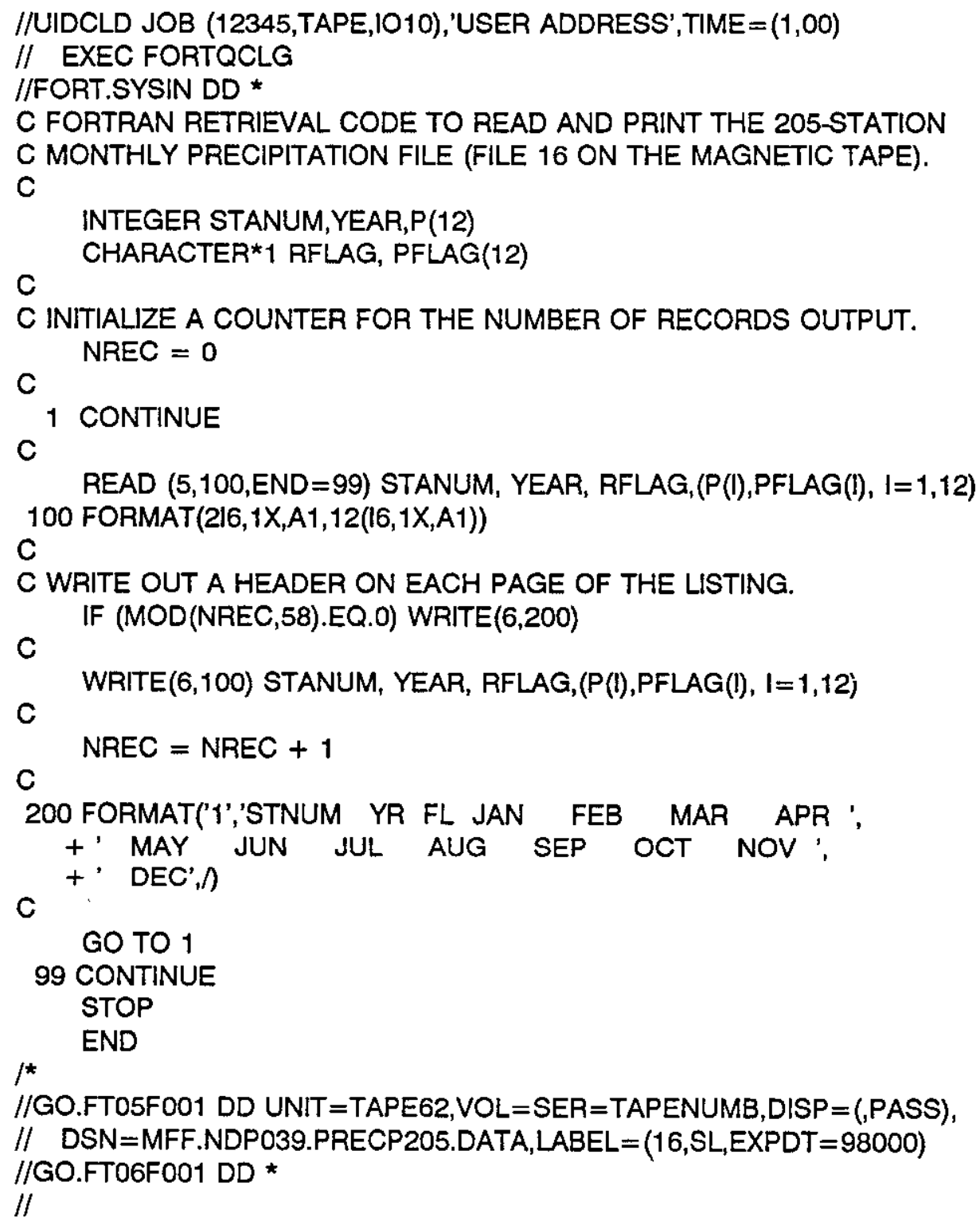




\section{LISTINGS OF THE SAS INPUT/OUTPUT RETRIEVAL PROGRAMS}

The following is a listing of the SAS data retrieval program provided on magnetic tape (File 7 on the tape) by CDIAC for reading and printing the station inventory file for the 60 -station data set (File 12 on the tape). The JCL statements (preceded by $/ /$ or $/^{*}$ ) shown in the following are not provided in the file on the magnetic tape. The JCL statements required will vary for each operating system. The JCL statements shown in the following are provided to illustrate the statements required by an individual at ORNL who has requested these data on a nine-track, $6250 \mathrm{BPI}$, standard-labeled tape with characters written in EBCDIC and who is attempting to read the tape on an IBM mainframe (e.g., IBM 3090).

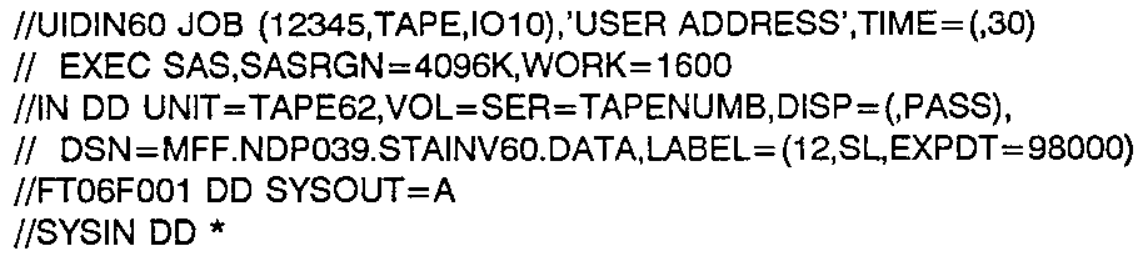

* SAS RETRIEVAL CODE TO READ AND PRINT THE STATION INVENTORY FILE FOR THE 60-STATION DATA SET (FILE 12 ON THE MAGNETIC TAPE);

DATA INV60;

INFILE IN;

INPUT SEQNUM 2-3 STNAME \$ 5-14 STANUM 17-21 LATDEG 25-26

LATMIN 28-29 LONDEG 33-35 LONMIN 37-38 ELEV 41-46 BEGYR 49-52;

FILE PRINT NOTITLE HEADER=NEWPAGE;

PUT_INFILE_;

RETURN;

NEWPAGE:

PUT @5 'STATION NO. DEG MIN DEG MIN ELEV(M) BEG'/;

RETURN;

RUN;

$I^{*}$

/I 
The following is a listing of the SAS data retrieval program provided on magnetic tape (File 8 on the tape) by CDIAC for reading and printing the station inventory file for the 205-station data sets (File 13 on the tape). The JCL statements (preceded by // or $/{ }^{*}$ ) shown in the following are not provided in the file on the magnetic tape. The JCL statements required will vary for each operating system. The JCL statements shown in the following are provided to illustrate the statements required by an individual at ORNL who has requested these data on a nine-track, $6250 \mathrm{BPI}$, standard-labeled tape with characters written in EBCDIC and who is attempting to read the tape on an IBM mainframe (e.g., IBM 3090).

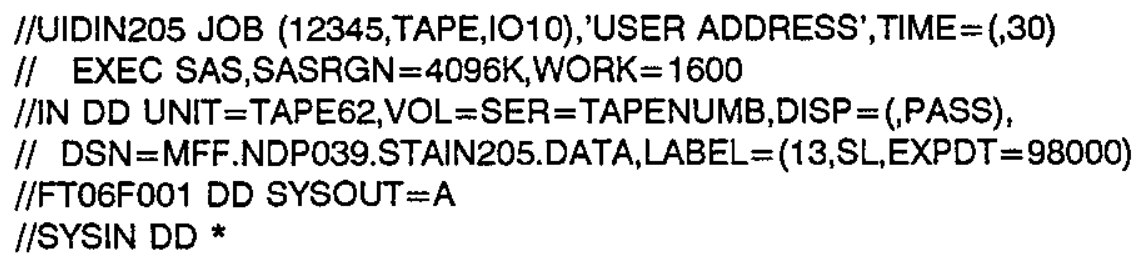

* SAS RETRIEVAL CODE TO READ AND PRINT THE STATION INVENTORY FILE FOR THE 205-STATION DATA SETS (FILE 13 ON THE MAGNETIC TAPE);

DATA INV205;

INFILE IN;

INPUT SEQNUM 2-4 STNAME \$ 6-25 STANUM 27-31 LATDEG 34-35

LATMIN 37-38 LONDEG 41-43 LONMIN 45-46 ELEV 49-54 TBEGYR 57-60 PBEGYR 63-66;

FILE PRINT NOTITLE HEADER $=$ NEWPAGE;

PUT_INFILE_;

RETURN;

NEWPAGE:

PUT @6 'STATION' @28 'NO. DEG MIN DEG MIN ELEV(M) TBEG PBEG'/;

RETURN;

RUN;

$I^{*}$

/I 
The following is a listing of the SAS data retrieval program provided on magnetic tape (File 9 on the tape) by CDIAC for reading and printing the 60 -station climate data file (File 14 on the tape). The JCL statements (preceded by $/ /$ or $/ *$ ) shown in the following are not provided in the file on the magnetic tape. The JCL statements required will vary for each operating system. The JCL statements shown in the following are provided to illustrate the statements required by an individual at ORNL who has requested these data on a nine-track, $6250 \mathrm{BPI}$, standard-labeled tape with characters written in EBCDIC and who is attempting to read the tape on an IBM mainframe (e.g., IBM 3090).

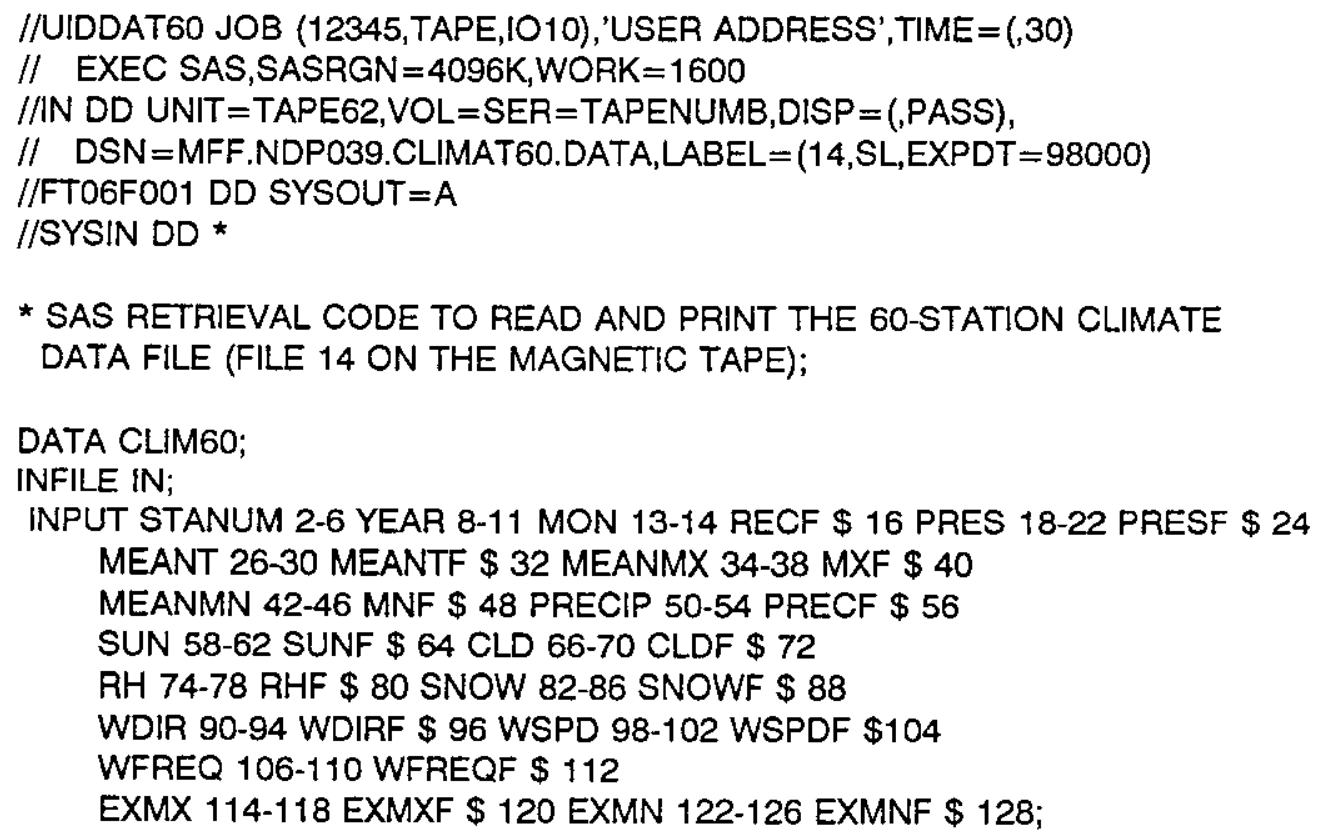

* SAS RETRIEVAL CODE TO READ AND PRINT THE 60-STATION CLIMATE DATA FILE (FILE 14 ON THE MAGNETIC TAPE);

DATA CLIM60;

INFILE IN;

INPUT STANUM 2-6 YEAR 8-11 MON 13-14 RECF \$ 16 PRES 18-22 PRESF \$ 24 MEANT 26-30 MEANTF \$ 32 MEANMX 34-38 MXF \$ 40 MEANMN 42-46 MNF \$ 48 PRECIP 50-54 PRECF \$ 56 SUN 58-62 SUNF $\$ 64$ CLD 66-70 CLDF $\$ 72$ RH 74-78 RHF $\$ 80$ SNOW 82-86 SNOWF $\$ 88$ WDIR 90-94 WDIRF \$ 96 WSPD 98-102 WSPDF $\$ 104$ WFREQ 106-110 WFREQF $\$ 112$ EXMX 114-118 EXMXF \$ 120 EXMN 122-126 EXMNF \$128;

FILE PRINT NOTITLE HEADER $=$ NEWPAGE

PUT_INFILE_;

RETÜRN;

NEWPAGE:

PUT @2 'STNUM YEAR MO FL PRES MEANT MEANMX MEANMN ' 'PRECIP SUN CLD RH SNOW WDIR WSPD' 'WFREQ EXMX EXMN'/; RETURN; RUN; $/ *$ 
The following is a listing of the SAS data retrieval program provided on magnetic tape (File 10 on the tape) by CDIAC for reading and printing the 205-station monthly mean temperature file (file 15 on the tape). The JCL statements (preceded by $/ /$ or $/^{*}$ ) shown in the following are not provided in the file on the magnetic tape. The JCL statements required will vary for each operating system. The JCL statements shown in the following are provided to illustrate the statements required by an individual at ORNL who has requested these data on a nine-track, $6250 \mathrm{BPI}$, standard-labeled tape with characters written in EBCDIC and who is attempting to read the tape on an IBM mainframe (e.g., IBM 3090).

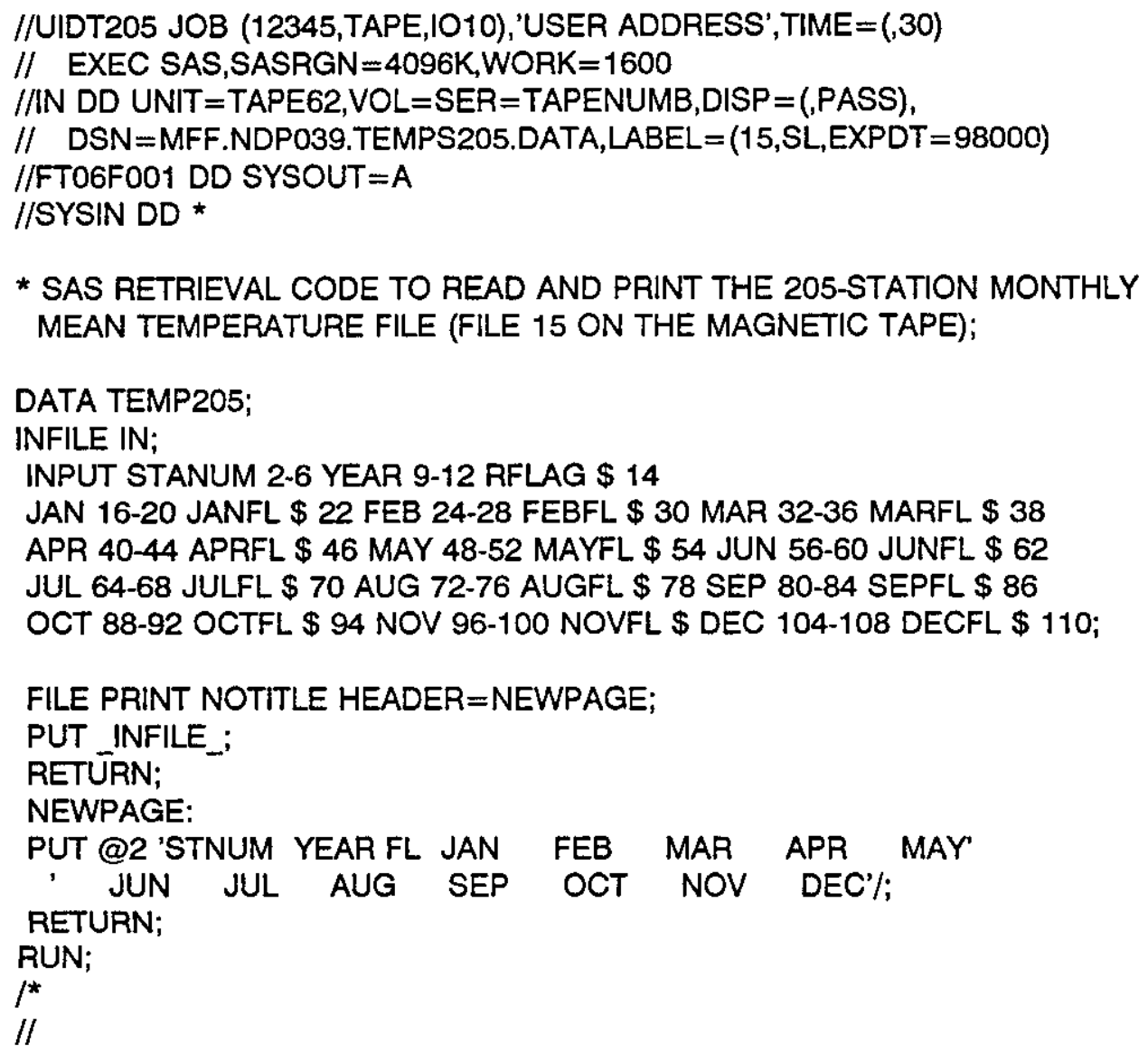


The following is a listing of the SAS data retrieval program provided on magnetic tape (File 11 on the tape) by CDIAC for reading and printing the 205-station monthly precipitation file (File 16 on the tape). The JCL statements (preceded by $/ /$ or $/{ }^{*}$ ) shown in the following are not provided in the file on the magnetic tape. The JCL statements required will vary for each operating system. The JCL statements shown in the following are provided to illustrate the statements required by an individual at ORNL who has requested these data on a nine-track, $6250 \mathrm{BPI}$, standard-labeled tape with characters written in EBCDIC and who is attempting to read the tape on an IBM mainframe (e.g., IBM 3090).

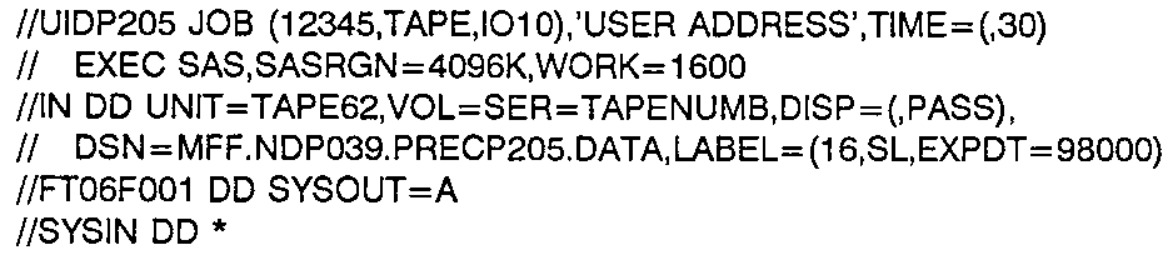

* SAS RETRIEVAL CODE TO READ AND PRINT THE 205-STATION MONTHLY PRECIPITATION FILE (FILE 16 ON THE MAGNETIC TAPE);

DATA PREC205;

INFILE IN;

INPUT STANUM 2-6 YEAR 9-12 RFLAG \$ 14

JAN 16-20 JANFL \$22 FEB 24-28 FEBFL \$30 MAR 32-36 MARFL \$ 38

APR 40-44 APRFL \$ 46 MAY 48-52 MAYFL \$ 54 JUN 56-60 JUNFL \$ 62 JUL 64-68 JULFL \$ 70 AUG 72-76 AUGFL \$ 78 SEP 80-84 SEPFL \$ 86 OCT 88-92 OCTFL \$ 94 NOV 96-100 NOVFL \$ DEC 104-108 DECFL \$110;

FILE PRINT NOTITLE HEADER=NEWPAGE;

PUT_INFILE_;

RETÜRN;

NEWPAGE:

PUT @2 'STNUM YEAR FL JAN FEB MAR APR MAY' ' JUN JUL AUG SEP OCT NOV DEC';

RETURN;

RUN;

$/$ *

II 


\section{VERIFICATION OF DATA TRANSPORT}

The five data files described herein may be read using the FORTRAN or SAS input/output routines provided. Users should verify that the files have been correctly transported to their systems by generating some or all of the statistics presented in Tables 8-12. These statistics were generated in SAS (PROC MEANS) but can be duplicated in other statistical packages or languages. If the statistics generated by the user differ from those presented here, the files may have been corrupted in transport.

These statistics are presented only as a tool to ensure proper reading of the data files. They are not to be construed as either a summary of the PRC climate data or an indicator of trends in these data. 
Table 8. Characteristics of numeric variables from the 60 -station inventory file (File 12)

\begin{tabular}{lcrrr}
\hline Variable & $\begin{array}{c}\text { Number of } \\
\text { observations }\end{array}$ & \multicolumn{1}{c}{$\begin{array}{l}\text { Mean } \\
\text { value }\end{array}$} & $\begin{array}{c}\text { Minimum } \\
\text { value }\end{array}$ & \multicolumn{1}{c}{$\begin{array}{c}\text { Maximum } \\
\text { value }\end{array}$} \\
\hline SEQNUM & 60 & 30.500000 & 1.000000 & 60.000000 \\
STANUM & 60 & 55890.733333 & 50527.000000 & 59758.000000 \\
LATDEG & 60 & 33.416667 & 20.000000 & 49.000000 \\
LATMIN & 60 & 30.433333 & 1.000000 & 58.000000 \\
LONDEG & 60 & 111.716667 & 81.000000 & 129.000000 \\
LONMIN & 60 & 28.533333 & 1.000000 & 59.000000 \\
ELEV & 60 & 501.736667 & 1.200000 & 3658.000000 \\
BEGYR & 60 & 1913.233333 & 1841.000000 & 1951.000000 \\
& & & & \\
\hline
\end{tabular}


Table 9. Characteristics of numeric variables from the 205-station inventory file (File 13)

\begin{tabular}{lcrrr}
\hline Variable & $\begin{array}{c}\text { Number of } \\
\text { observations }\end{array}$ & $\begin{array}{c}\text { Mean } \\
\text { value }\end{array}$ & $\begin{array}{c}\text { Minimum } \\
\text { value }\end{array}$ & \multicolumn{1}{c}{$\begin{array}{c}\text { Maximum } \\
\text { value }\end{array}$} \\
\hline SEQNUM & 205 & 103.00000 & 1.000000 & 205.000000 \\
STANUM & 205 & 55398.770732 & 50136.000000 & 59855.000000 \\
LATDEG & 205 & 34.156098 & 19.000000 & 53.000000 \\
LATMIN & 205 & 30.180488 & 0.000000 & 59.000000 \\
LONDEG & 205 & 109.273171 & 75.000000 & 131.000000 \\
LONMIN & 205 & 28.775610 & 0.000000 & 59.000000 \\
ELEV & 205 & 875.800000 & 1.300000 & 4728.000000 \\
TBEGYR & 205 & 1944.243902 & 1907.000000 & 1961.000000 \\
PBEGYR & 205 & 1944.609756 & 1880.000000 & 1961.000000 \\
\hline
\end{tabular}


Table 10. Characteristics of numeric variables from the 60 -station climate data file (File 14)

\begin{tabular}{lrrrr}
\hline Variable & $\begin{array}{c}\text { Number of } \\
\text { observations }\end{array}$ & $\begin{array}{c}\text { Mean } \\
\text { value }\end{array}$ & $\begin{array}{c}\text { Minimum } \\
\text { value }\end{array}$ & $\begin{array}{c}\text { Maximum } \\
\text { value }\end{array}$ \\
\hline STANUM & 50521 & 56133.637101 & 50527.000000 & 59758.000000 \\
YEAR & 50521 & 1948.734091 & 1841.000000 & 1988.000000 \\
MON & 50521 & 6.509155 & 1.000000 & 12.000000 \\
PRES & 50521 & 4720.056867 & -9999.000000 & 10360.000000 \\
MEANT & 50521 & -1048.202787 & -9999.000000 & 328.000000 \\
MEANMX & 50521 & -1604.397063 & -9999.000000 & 395.000000 \\
MEANMN & 50521 & -1660.756299 & -9999.000000 & 280.000000 \\
PRECIP & 50521 & 398.641753 & -9999.000000 & 10318.000000 \\
SUN & 50521 & -1852.183924 & -9999.000000 & 3906.000000 \\
CLD & 50521 & -3063.088241 & -9999.000000 & 1000.000000 \\
RH & 50521 & -1630.216187 & -9999.000000 & 990.000000 \\
SNOW & 50521 & -3290.252390 & -9999.000000 & 310.000000 \\
WDIR & 50521 & -3432.722551 & -9999.000000 & 3600.000000 \\
WSPD & 50521 & -2458.855169 & -9999.000000 & 94.000000 \\
WFREQ & 50521 & -4941.773500 & -9999.000000 & 940.000000 \\
EXMX & 50521 & -9268.719107 & -9999.000000 & 432.000000 \\
EXMN & 50521 & -9284.591200 & -9999.000000 & 244.000000 \\
& & & & \\
\hline
\end{tabular}


Table 11. Characteristics of numeric variables from the 205-station monthly mean temperature file (File 15)

\begin{tabular}{lcccc}
\hline Variable & $\begin{array}{c}\text { Number of } \\
\text { observations }\end{array}$ & $\begin{array}{c}\text { Mean } \\
\text { value }\end{array}$ & $\begin{array}{c}\text { Minimum } \\
\text { value }\end{array}$ & $\begin{array}{c}\text { Maximum } \\
\text { value }\end{array}$ \\
\hline STANUM & 9155 & 55468.011906 & 50136.000000 & 59855.000000 \\
YEAR & 9155 & 1964.746696 & 1907.000000 & 1988.000000 \\
JAN & 9155 & -1002.653960 & -9999.000000 & 208.000000 \\
FEB & 9155 & -965.259421 & -9999.000000 & 225.000000 \\
MAR & 9155 & -906.209285 & -9999.000000 & 251.000000 \\
APR & 9155 & -839.558493 & -9999.000000 & 268.000000 \\
MAY & 9155 & -792.198143 & -9999.000000 & 370.000000 \\
JUN & 9155 & -764.451338 & -9999.000000 & 332.000000 \\
JUL & 9155 & -753.769416 & -9999.000000 & 360.000000 \\
AUG & 9155 & -765.309011 & -9999.000000 & 371.000000 \\
SEP & 9155 & -795.136210 & -9999.000000 & 319.000000 \\
OCT & 9155 & -852.265647 & -9999.000000 & 305.000000 \\
NOV & 9155 & -928.904533 & -9999.000000 & 286.000000 \\
DEC & 9155 & -989.643474 & -9999.000000 & 228.000000 \\
& & & & \\
\hline
\end{tabular}


Table 12. Characteristics of numeric variables from the 205-station monthly total precipitation file (File 16)

\begin{tabular}{lcccr}
\hline Variable & $\begin{array}{c}\text { Number of } \\
\text { observations }\end{array}$ & $\begin{array}{c}\text { Mean } \\
\text { value }\end{array}$ & $\begin{array}{c}\text { Minimum } \\
\text { value }\end{array}$ & $\begin{array}{c}\text { Maximum } \\
\text { value }\end{array}$ \\
\hline STANUM & 9086 & 55481.342945 & 50136.000000 & 59855.000000 \\
YEAR & 9086 & 1963.914484 & 1880.000000 & 1988.000000 \\
JAN & 9086 & -800.750165 & -9999.000000 & 2685.000000 \\
FEB & 9086 & -726.452124 & -9999.000000 & 5067.000000 \\
MAR & 9086 & -574.599384 & -9999.000000 & 6377.000000 \\
APR & 9086 & -350.912063 & -9999.000000 & 6921.000000 \\
MAY & 9086 & -72.017389 & -9999.000000 & 8262.000000 \\
JUN & 9086 & 168.092450 & -9999.000000 & 11412.000000 \\
JUL & 9086 & 375.360225 & -9999.000000 & 9319.000000 \\
AUG & 9086 & 255.803324 & -9999.000000 & 9040.000000 \\
SEP & 9086 & -154.390931 & -9999.000000 & 9200.000000 \\
OCT & 9086 & -482.246753 & -9999.000000 & 8115.000000 \\
NOV & 9086 & -690.477108 & -9999.000000 & 8059.000000 \\
DEC & 9086 & -809.260511 & -9999.000000 & 2496.000000 \\
& & & & \\
\hline
\end{tabular}


APPENDICES 


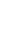


APPENDIX A

INSTRUMENTATION AND DATA COLLECTION METHODS OF STATIONS IN THE PRC 60-STATION CLIMATE NETWORK 



\section{BAROMETRIC PRESSURE}

Fortin and Kew-pattern barometers and an aneroid barograph are employed. They are positioned in observation rooms to decrease temperature variability. The two instruments are positioned near each other, away from doors and windows, and are calibrated at regular intervals.

Station pressures are recorded in millibars, with monthly means being calculated from daily means and reported to the nearest tenth of a millibar. Mercury column heights, expressed in millimeters, had been reported before 1953 for some stations, but they have been converted to millibars. Since 1950 , readings have been corrected and reduced for temperature effects, instrumental error, and gravity error (including latitude and altitude effects). Readings were not corrected for gravity effects prior to 1950 .

\section{TEMPERATURE}

Dry- and wet-bulb thermometers are fixed together in an instrument shelter. The standard bulb heights used prior to 1950 are not known. For the period 1954-1960 the standard height was $2 \mathrm{~m}$. The standard height used since 1961 is $1.5 \mathrm{~m}$, as it was for the period 1950-1953. Observing times have varied over the years. The observing times for each station prior to 1950 , along with details on which observations were used in calculating the daily mean, may be found in the accompanying station histories (Appendix B). Since 1950, observations have been made using Local Standard Time (LST) (1951-1953), Local Mean Solar Time (LMST) (1954-July 1960), and Beijing Time (BT) (August 1960-present).

Maximum and minimum thermometers are laid horizontally in the same shelter, 3 and $2 \mathrm{~cm}$ higher, respectively, than the dry- and wet-bulb thermometers. Prior to 1951, observation and adjustment were performed at $2000 \mathrm{BT}$, but since 1951 have taken place at $2000 \mathrm{LST}$.

\section{RELATTVE HUMIDITY}

A ventilated psychrometer and hair hygrometer (models not given) are housed in separate shelters. Readings from each instrument are translated into relative humidities via their respective tables or charts. Temperature observations are made simultaneously. Circa 1953, certain stations (not identified) used a different humidity table which resulted in errors of $1-2 \%$.

\section{PRECIPITATION}

A Dines tilting-siphon rain gauge and a siphon rainfall recorder are used. Observation times prior to 1950 are not known. Since then, observations have been taken at midnight LST (1951-1953), 1900 LMST (1954-July 1960), and 2000 BT 
(August 1960-present). Observed totals may include liquid precipitation, liquid equivalent of solid precipitation or frost, dew, or fog. Amounts less than $0.05 \mathrm{~mm}$ are recorded as zero.

\section{SUNSHINE DURATION}

Prior to 1954, a Jordan Photographic Sunshine Recorder was used, and since 1954 a Campbell-Stokes Sunshine Recorder has been used. CAS states that some monthly sunshine durations have been estimated, but these entries have not been flagged or documented.

\section{CLOUD AMOUNT}

Cloud amount has been estimated in tenths of sky cover by observers. Zero indicates clear skies; 10 indicates overcast skies. Monthly mean cloud amounts are obtained from averaging mean daily amounts for the month, multiplying by 10 to obtain a percentage, and rounding this value to the nearest whole percent. CAS states the data contain many estimates, but, as with the sunshine data, these have not been identified via flagging or documentation.

\section{WIND DATA}

Since 1954, an EL electric wind direction and speed device and a Dines wind direction and speed recorder have been used. Receivers for wind instruments are mounted on a pole 10-12 m above ground level. The type of instrument used before 1954 is unclear, but at the following stations the Beaufort Scale was employed:

\footnotetext{
ZhangYe (52652)

LanZhou (52889)

YanTai (54765)

LaSa (55591)

TengChong (56739)

TianShui (57006)

ZhengZhou (57083)

YiChang (57461)

ChangSha (57679)

GuiYang (57816)

AnQing (58424)

WenZhou (58659)

FuZhou (58847)

XiaMen (59134)

WuZhou (59265)

ShanTou (59316)

HaiKou (59758)
} 
The Beaufort Scale entries from these stations have been converted to $\mathrm{m} / \mathrm{s}$.

Observation times used in calculating the daily mean are unclear for the period prior to 1951. Several different time groups were used over the period 1951-1953 (Appendix B). For the period 1954-July 1960, observations from 0100, 0700, 1300 and 1900 were used (assumably LMST), and since August 1960, observations from 0200, 0800, 1400, and 2000 have been used (assumably BT). Wind direction is recorded in $22.5^{\circ}$ increments of azimuth clockwise from north (sixteen directions), with $0^{\circ}$ indicating calm winds and $360^{\circ}$ indicating a north wind. The monthly dominant wind direction is simply the most frequent wind direction observed during the month, and its frequency (percentage of the time it was observed) is the dominant wind frequency. 



\section{APPENDIX B \\ STATION HISTORIES OF THE PRC 60-STATION CLIMATE NETWORK}

Data source codes in each station history correspond to the numbered data sources in Appendix C. 


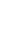




\section{B-3}

A. Mair Data Sources
1. $1909.1-1950.12$
1909-1930 (Total amount of cloud)
(16)
1951.1-1960.12
3. $1961.1-1980.12$
4. $1981-1983$
(14)
$(18)(6)(7)(8)(9)(10)(11)$
5. 1961-1970 (The mean pressure is taken from)
(13)
(157)

B. Location of Station, Time Standard and Times of Observation

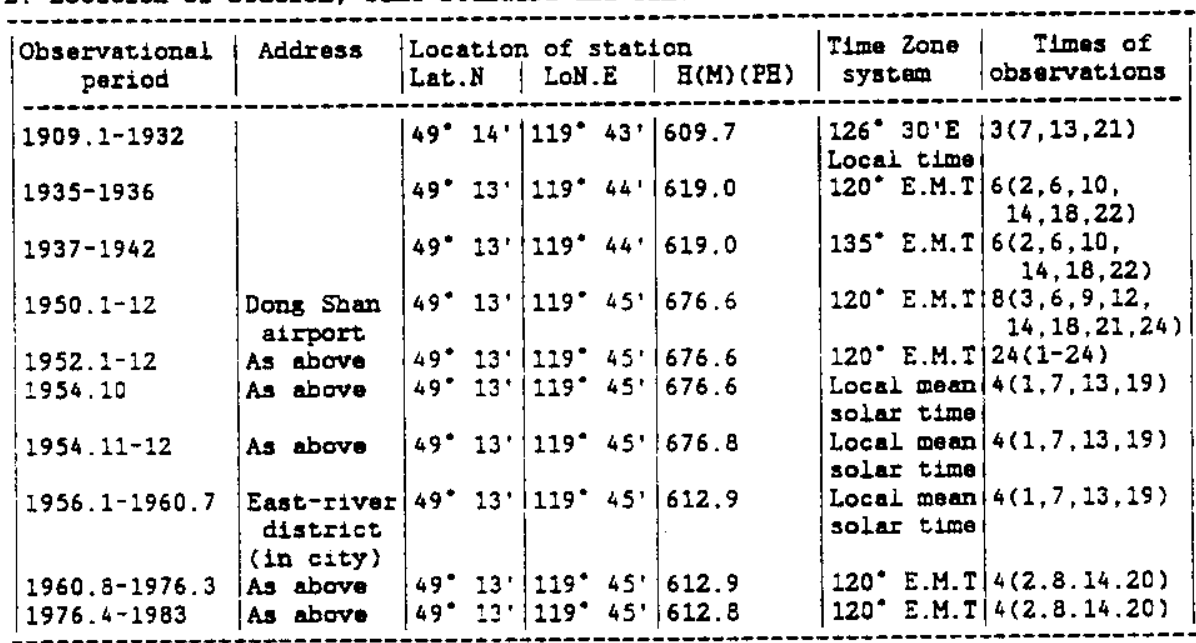

C. Number of Observations Used for Calculating the Dally Mean

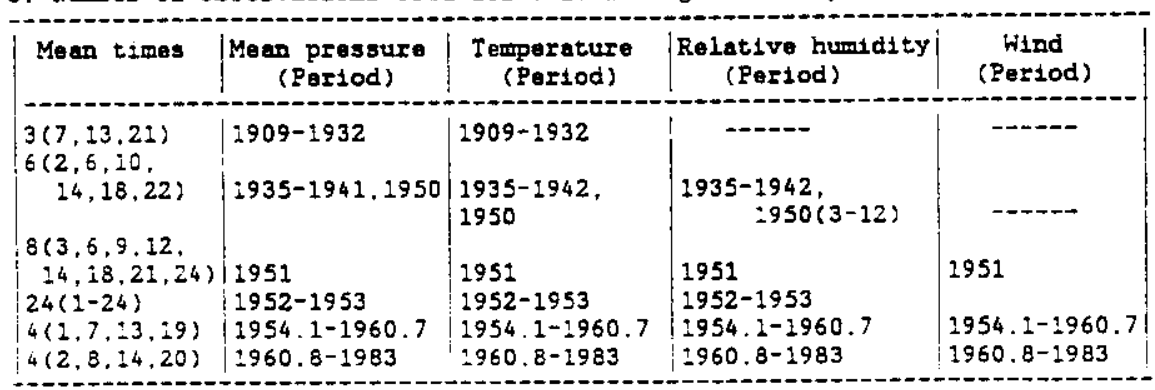

D. Remariks:

1.Old-name:" Hu Lun ". 
A. Main Data Sources

$\begin{array}{lr}\text { i. } 1939-1950 & (19) \\ \text { 2. } 1951-1980 & (20) \\ \text { 3. } 1971-1980 & (159) \\ \text { 4. } 1981-1983 & (13) \\ \text { 5. } 1951-62 \text { (Mean maximum and minimum temperature) } & (12) \\ 1963-70 & (156) \\ 1971-80 & (159)\end{array}$

B. Location of Station, Time Standard and Iimes of Observation

\begin{tabular}{|c|c|c|c|c|c|c|}
\hline $\begin{array}{c}\text { Observational } \\
\text { period }\end{array}$ & Address & \begin{tabular}{|l} 
Locatior \\
Lat.N
\end{tabular} & $\begin{array}{l}n \text { of stat } \\
\text { Lod.E }\end{array}$ & $\int_{\mathrm{B}}^{100}(\mathrm{M})(\mathrm{PH})$ & $\mid \begin{array}{c}\text { Time Zone } \\
\text { systam }\end{array}$ & $\begin{array}{c}\text { Times of } \\
\text { observations }\end{array}$ \\
\hline $1939-1945$ & & $49^{\circ} 10^{\circ}$ & $125^{\circ} 13^{\circ}$ & ${ }^{222.3}(223.7)$ & $\mid 135^{\circ}$ E.M.T & \\
\hline 1949.8 & $\begin{array}{c}\text { Nen jians } \\
\text { (tom })\end{array}$ & $49^{\circ} 10^{\circ}$ & $125^{\circ} 13^{\circ}$ & 222.3 & $120^{\circ}$ E.M.I & $\begin{array}{r}5(6,10,14 \\
18,22)\end{array}$ \\
\hline $1949.9,1950$ & (incity) & $49^{\circ} 10^{\circ}$ & $125^{\circ} 13^{\circ}$ & 222.3 & $120^{\circ}$ E.M.I & $4(6,10,14,18)$ \\
\hline 1951 & $\begin{array}{l}X \text { in Eua } \\
\text { street }\end{array}$ & $49^{\circ} 10^{\circ}$ & $125^{\circ} 13^{\prime}$ & $222.3(223.7)$ & $120^{\circ}$ E.M.T & $\begin{array}{c}6(2,6,10,14 \\
18,22)\end{array}$ \\
\hline $1952-53$ & As above & $49^{\circ} 10^{\circ}$ & $125^{\circ} 13^{\circ}$ & $\frac{222.3}{(223.7)}$ & $\mid$\begin{tabular}{ll|} 
Local mean \\
solar time
\end{tabular} & $\left(\begin{array}{r}8(3,6,9,12, \\
14,18,21,24)\end{array}\right.$ \\
\hline $2954.1-60.6$ & As above & $49^{\circ} 10^{\circ}$ & $125^{\circ} 13^{\prime}$ & $\frac{222.3}{(223.7)}$ & $120^{\circ}$ E.M.I & $24(1-24)$ \\
\hline $1960.7-1972.5$ & As above & $49^{\circ} 10^{\circ}$ & $125^{\circ} 13^{\circ}$ & 222.3 & $120^{\circ}$ E.M.T & $4(2,8,14,20)$ \\
\hline 1972.6-Non & $\begin{array}{l}\text { Southern } \\
\text { suburb }\end{array}$ & $49^{\circ} 10^{\circ}$ & $125^{\circ} 14^{\circ}$ & 242.2 & $120^{\circ}$ E.M.T & \\
\hline
\end{tabular}

c. Number of Observations Used for Calculating the Da1ly Mean

\begin{tabular}{|c|c|c|c|c|}
\hline Mean times & $\begin{array}{c}\text { Mean pressure } \\
\text { (Period) }\end{array}$ & $\begin{array}{c}\text { Temperature } \\
\text { (Pertod) }\end{array}$ & $\left|\begin{array}{c}\text { Relative humidtty } \\
\text { (Feriod) }\end{array}\right|$ & $\begin{array}{c}\text { Cloud } \\
\text { (Period) }\end{array}$ \\
\hline $\begin{array}{c}6(2,6,10,14 \\
18,22) \\
5(6,10,14,18, \\
22) \\
8(3,6,9,12) \\
14,18,21,24) \\
24(1-24) \\
4(1,7,13,19) \\
4(2,8,14,20)\end{array}$ & $\left\{\begin{array}{l}1939-1945.7 \\
1949.9-1950 \\
\\
1951 \\
1952-1953 \\
1954.1-1960.6 \\
1960.7-1983\end{array}\right.$ & $\begin{array}{l}1951 \\
1952-1953 \\
1954.1-1960.6 \\
1960.7-1983\end{array}$ & $\begin{array}{l}1951 \\
1952-1953 \\
1954 \cdot 1-1960.6 \\
1960.7-1983\end{array}$ & $\begin{array}{l}1951 \\
1952-1953 \\
1954.1-1960.6 \\
1960.7-1983\end{array}$ \\
\hline
\end{tabular}

2. Remarks : 
A. Main Data Sources

$\begin{array}{lr}\text { 1. } 1914-1950 & (21) \\ \text { 2. } 1914-1932 & (15) \\ \text { 3. } 1951-1960 & (22) \\ \text { 4. } 1971-1980 & (160) \\ \text { 5. } 1981-1983 & (13)\end{array}$

B. Location of Station, IIme Standard and Iimes of Observation

\begin{tabular}{|c|c|c|c|c|c|c|}
\hline $\begin{array}{c}\text { Observational } \\
\text { pertod }\end{array}$ & Address & $\left|\begin{array}{l}\text { Locat tor } \\
\text { Lat. }\end{array}\right|$ & $\left|\begin{array}{l}\text { of statt } \\
\text { LoN.E }\end{array}\right|$ & $\begin{array}{l}t \in n \\
E(M)(P E)\end{array}$ & $\begin{array}{l}\text { Time Zone } \\
\text { system }\end{array}$ & $\begin{array}{c}\text { Times of } \\
\text { observations }\end{array}$ \\
\hline $3914-1932$ & & $48^{\circ} 46^{\prime} \mid$ & $\left|121^{\circ} 55^{\prime}\right|$ & 698.8 & $126^{\circ} 30^{\circ}$ & $3(7,23,21)$ \\
\hline $1951.1-10$ & 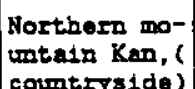 & $48^{\circ} 46^{\prime}$ & $121^{\circ} 55^{\prime}$ & ---- & $120^{\circ}$ E.M.I & $\begin{array}{r}8(3,6,9,12 \\
14,18,21,24)\end{array}$ \\
\hline $1951.11-12$ & $\begin{array}{l}2500 \mathrm{M} \text { away } \\
\text { from the oid } \\
\text { eddress }\end{array}$ & $48^{\circ} 46^{\prime}$ & $121^{\circ} 55^{\prime}$ & 738.7 & $120^{\circ}$ E.M.I & $\begin{array}{l}8(3,6,9,12 \\
14,18,21,24)\end{array}$ \\
\hline $\begin{array}{l}1952.1-1953.12 \\
1954.2-1960.7\end{array}$ & $\begin{array}{l}\text { As above } \\
\text { As above }\end{array}$ & $\begin{array}{l}48^{\circ} 46^{\prime} \\
48^{\circ} 46^{\prime}\end{array}$ & $121^{\circ} 55^{\prime}$ & $\begin{array}{l}738.7 \\
738.7\end{array}$ & $\begin{array}{l}120^{\circ} \text { E.M.I } \\
\text { Local meman } \\
\text { solar timo }\end{array}$ & $\left\{\begin{array}{l}24(1-24) \\
4(1,7,13,19)\end{array}\right.$ \\
\hline $\begin{array}{l}1960.8-1960.12 \\
1961.1-1970.12\end{array}$ & $\begin{array}{l}\text { As above } \\
\text { As above }\end{array}$ & $\begin{array}{l}48^{\circ} 46^{\prime} \\
48^{\circ} 46^{\prime}\end{array}$ & $\left|\begin{array}{l}121^{\circ} 55^{\circ} \\
121^{\circ} 55^{\prime}\end{array}\right|$ & $\begin{array}{l}738.7 \\
738.7\end{array}$ & $\begin{array}{c}120^{\circ} \text { E.M.I } \\
(B \in 1 j \pm n g \\
\text { timo })\end{array}$ & $\begin{array}{l}4(2,8,14,20) \\
4(2,8,14,20)\end{array}$ \\
\hline 1971.1-now & As abovo & $48^{\circ} 46^{\prime}$ & $121^{\circ} 55^{\prime}$ & 739.4 & $\begin{array}{c}(B \in I j \operatorname{lag} \\
\operatorname{sim\theta })\end{array}$ & $4(2,8,14,20)$ \\
\hline
\end{tabular}

C. Number of Observations Used for Calculating the Daily Mean

\begin{tabular}{|c|c|c|c|c|}
\hline Mean times & $\begin{array}{c}\text { Mean preasura } \\
\text { (Period) }\end{array}$ & $\begin{array}{c}\text { Temperaturo } \\
\text { (Porlod) }\end{array}$ & $\begin{array}{c}\text { Relattve humidity } \\
\text { (Period) }\end{array}$ & $\begin{array}{l}\text { Wind } \\
\text { (Pariod) }\end{array}$ \\
\hline $\begin{array}{l}3(7,13,21) \\
8(3,6,9,12, \\
14,18,21,24) \\
24(1-24) \\
4(1,7,13,19) \\
4(2,8,14,20)\end{array}$ & $\mid \begin{array}{c}1915-1932 \\
---1- \\
1952-1953 \\
1954.1-1960.7 \\
1960.8-\text { now }\end{array}$ & $\begin{array}{l}1914-1932 \\
1951 \\
1952-1953 \\
1954.1-1960.7 \\
1960.8-\text { now }\end{array}$ & $\begin{array}{l}1951 \\
1952-1953 \\
1954.1-1960.7 \\
1960.7-\text { now }\end{array}$ & $\begin{array}{l}1951.1-12 \\
1952-1953 \\
1954.1-1960.7 \\
1960.7-20 \%\end{array}$ \\
\hline
\end{tabular}

D. Remarixs:

․ Old-name: "Gul Xi Bo Ke Tu". 
A. Main Data Sources

$\begin{array}{lr}\text { 1. } 1909-1928 & (1) \\ \text { 2. } 1909-1932 & (3) \\ 1928-1950 & (161) \\ \text { 3. } 1951-1980 & (20) \\ \text { 4. } 1981-1983 & (13) \\ \text { 5. } 1951-1962 \text { (Mean/max/min temperature } & (12) \\ 1963-1970 & \text { and total cloud amount) } \\ 1971-1980 & (156) \\ & (159)\end{array}$

B. Location of Station, Time Standard and Times of Observation

\begin{tabular}{|c|c|c|c|c|c|c|c|}
\hline $\begin{array}{l}\text { Joservational } \\
\text { pertod }\end{array}$ & Adidress & $\left|\begin{array}{|}\text { Location } \\
\text { Lat.s }\end{array}\right|$ & $\left|\begin{array}{l}\text { of stati } \\
\text { Los. }\end{array}\right|$ & $\begin{array}{l}\operatorname{lon} \\
\mid \mathrm{E}(\mathrm{M})(\mathrm{PE})\end{array}$ & $\mid \begin{array}{c}\text { Time } \\
\text { syst }\end{array}$ & Zone & $\begin{array}{c}\text { Times of } \\
\text { observations }\end{array}$ \\
\hline $1909-1928$ & $\begin{array}{l}\text { In routine } \\
\text { office place } \\
\text { (1n city) }\end{array}$ & $47^{\circ} 10^{\prime} \mid$ & $123^{\circ} 49^{\prime} \mid$ & 149.3 & & & \\
\hline $\begin{array}{l}1928-1930.4 \\
1930.5-1935 \\
1933 \\
1936-1938 \\
1939-1942.4 \\
1949.6 \\
1949.7-12\end{array}$ & $\begin{array}{l}\text { As above } \\
\text { As above } \\
\text { As above } \\
\text { As above } \\
\text { As above }\end{array}$ & $\left|\begin{array}{ll}47^{\circ} & 22 \\
47^{\circ} & 22 \\
47^{\circ} & 22 \\
47^{\circ} & 46^{\circ} \\
47^{\circ} & 20^{\circ} \\
47^{\circ} & 20^{\circ} \\
47^{\circ} & 20^{\circ}\end{array}\right|$ & 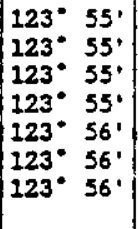 & $\begin{array}{l}152.2 \\
152.2 \\
152.2 \\
152.2 \\
147.0 \\
147.0 \\
147.0\end{array}$ & $\begin{array}{l}120^{\circ} \\
135^{\circ} \\
135^{\circ} \\
120^{\circ} \\
120^{\circ} \\
120^{\circ} \\
120^{\circ}\end{array}$ & $\begin{array}{l}\text { E.M.I } \\
\text { E.M.T } \\
\text { E.M.I } \\
\text { E.M.I } \\
\text { E.M.I } \\
\text { E.M.I } \\
\text { E.M.I }\end{array}$ & $\begin{array}{l}1(10) \\
3(5,13,21) \\
3(6,14,22) \\
3(6,14,22) \\
6(2,6,10,14 \\
4(6,10,14,18) \\
6(2,6,10,14 \\
18,22)\end{array}$ \\
\hline 1950 & $\begin{array}{l}\text { No. 1. Moteo-s } \\
\text { treot Shans- } \\
\text { fu road }\end{array}$ & $\left.47^{\circ} 20^{\prime}\right)$ & $123^{\circ} 56^{\prime}$ & 147.0 & $120^{\circ}$ & E.M.T & $\begin{array}{r}6(2,6,10,14 \\
18,22)\end{array}$ \\
\hline $\begin{array}{l}1951-1952 \\
1953-1960.7\end{array}$ & $\begin{array}{l}\text { As abov: } \\
\text { As above }\end{array}$ & $\left|\begin{array}{ll}47^{\circ} & 20^{\circ} \\
47^{\circ} & 20^{\circ}\end{array}\right|$ & $\begin{array}{l}123^{\circ} 56^{\circ} \\
123^{\circ} 56^{\circ}\end{array}$ & $\begin{array}{l}147.0 \\
147.0\end{array}$ & $\begin{array}{l}120^{\circ} \\
\text { Local } \\
\text { soler }\end{array}$ & $\begin{array}{c}\text { E.M.I } \\
\text { mean } \\
\text { time }\end{array}$ & $\left\{\begin{array}{l}24(1-24) \\
4(1,7,13,19)\end{array}\right.$ \\
\hline $1960.8-1963.12$ & As above & $47^{\circ} 20^{\circ}$ & $123^{\circ} 56^{\prime}$ & 147.0 & $(B \bullet 15:$ & $\begin{array}{l}\ln (8 \\
t 1 \mathrm{~m} \theta\end{array}$ & $4(2,8,14,20)$ \\
\hline $1964.1-1983$ & $\begin{array}{l}\text { Wost-big br- } \\
\text { idgo-west } \\
\text { ( in city ) }\end{array}$ & $47^{\circ} 23^{\circ}$ & $123^{\circ} 55^{\circ}$ & 145.9 & $(B \circ 1 j$ & $\begin{array}{l}\operatorname{lng} \\
t \text { imo }\end{array}$ & $4(2,8,14,20)$ \\
\hline
\end{tabular}

C. Number of Observations Used for Calculating the Dally Mean

\begin{tabular}{|c|c|c|c|c|}
\hline Mean times & $\begin{array}{c}\text { Meam prassure } \\
\text { (Period) }\end{array}$ & $\begin{array}{l}\text { Temperature } \\
\text { (Period) }\end{array}$ & $\begin{array}{c}\text { Relat1ve humidity } \\
\text { (Portod) }\end{array}$ & $\begin{array}{l}\text { Hind } \\
\text { (Period) }\end{array}$ \\
\hline $\begin{array}{l}3(5,13,21) \\
3(6,14,22) \\
4(6,10,14,18) \\
6(2,6,10,14) \\
18,22)\end{array}$ & $\begin{array}{l}1930-1932 \\
1934-1935 \\
1933,1936\end{array}$ & $\begin{array}{l}1930-1932 \\
1934-1935 \\
1933,1936-1938 \\
1950.11-12 \\
1949.6 \\
1939-1942.4 \\
1949.7-12 .\end{array}$ & $\begin{array}{l}19306,1932 \\
1934-1935 \\
1933-1936 \\
\\
1949.6 \\
1939-1942.4 \\
1949.7-12,1950\end{array}$ & \\
\hline $\begin{array}{l}24(1-24) \\
4(1,7,13,19) \\
4(2,8,14,20)\end{array}$ & $\mid \begin{array}{l}1951-53 \\
1954.1-60.6 \\
1960.7-1983\end{array}$ & $\begin{array}{l}1951-53 r \\
1954.1-1960.6 \\
1960.7-1983\end{array}$ & $\left\{\begin{array}{l}1951-53 \\
1954.1-1960.6 \\
1960.7-1983\end{array}\right.$ & $\begin{array}{l}1951-53 \\
1954.1-1960.6 \\
1960.7-1983\end{array}$ \\
\hline
\end{tabular}

D. Remarixs:

1. Old name: "Long Jiang Ang Ang XI". 
A. Main Data Sources

$\begin{array}{lr}\text { 1. } 1898-1906 & (3) \\ \text { 2. } 1909-1950 & (23) \\ \text { 3. } 1951-1980 & (20) \\ \text { 4. } 1981-1983 & (13) \\ \text { 5. } 1951-1962 & (12) \\ 1971-1980 & (159) \\ 1963-1970 & (156)\end{array}$

B. Location of Station. Iime Standard and Times of Observation

\begin{tabular}{|c|c|c|c|c|c|c|}
\hline $\begin{array}{c}\text { Observattonal } \\
\text { period }\end{array}$ & Address & $\left|\begin{array}{l|}\text { Locattoon } \\
\text { Lat. I }\end{array}\right|$ & $\mid \begin{array}{l}\text { of stat } \\
\text { Lox.E }\end{array}$ & IOn & $\mid \begin{array}{c}\text { T1me Zone } \\
\text { systed }\end{array}$ & $\begin{array}{c}\text { Times of } \\
\text { observations }\end{array}$ \\
\hline $\begin{array}{l}1898-1906 \\
1909-1935 \\
1936-1942\end{array}$ & -ב- & $\left|\begin{array}{ll}45^{\circ} & 46^{\prime} \\
45^{\circ} & 45^{\circ} \\
45^{\circ} & 45^{\prime}\end{array}\right|$ & $\left|\begin{array}{ll}126^{\circ} & 58^{\prime} \\
126^{\circ} & 38^{\prime} \\
126^{\circ} & 38^{\prime}\end{array}\right|$ & $\begin{array}{l}147.0 \\
145.1 \\
145.1\end{array}$ & $\begin{array}{l}120^{\circ} \text { E.M.T } \\
135^{\circ} \text { E.M.T }\end{array}$ & $\left\{\begin{array}{c}3(5,13,21) \\
6(2,6,10,14 \\
18,22)\end{array}\right.$ \\
\hline $1949-1950$ & Nan Gang big & $45^{\circ} 45$ & $126^{\circ} 38^{\circ}$ & 145.1 & $120^{\circ}$ E.M.T & $\begin{array}{r}6(2,6,10,14 \\
18,22)\end{array}$ \\
\hline $1951-1953$ & As above & $45^{\circ} 45^{\prime}$ & $126^{\circ} 38^{\prime}$ & 145.1 & $120^{\circ}$ E.M.T & $\begin{array}{r}24(1-24) \\
18,22)\end{array}$ \\
\hline $1954-1960.6$ & $\begin{array}{l}\text { GonsBin road, } \\
\text { Xiang Tan dis- } \\
\text { trict }\end{array}$ & $\left.45^{\circ} 45^{\prime}\right\}$ & $\left|126^{\circ} 46^{\prime}\right|$ & 146.0 & $\begin{array}{l}\text { Local mean } \\
\text { solar time }\end{array}$ & $4(1,7,13,19)$ \\
\hline $1971.1-1979$ & Xue fu road & $45^{\circ} 41^{\prime}$ & $126^{\circ} 37^{\prime}$ & 171.7 & $\begin{array}{c}\text { (B०IJIng } \\
\text { time) }\end{array}$ & $4(2,8,14,20)$ \\
\hline $1980-1983$ & $\begin{array}{l}\text { No. } 47 \text {. Eloct- } \\
\text { rictty-carbon } \\
\text { lactory stra- } \\
\text { ot, Gong Bin } \\
\text { road }\end{array}$ & $45^{\circ} 45^{\prime}$ & $126^{\circ} 46^{\prime}$ & 242.3 & $\begin{array}{l}\text { (Beijing } \\
\text { time) }\end{array}$ & $4(2,8,14,20)$ \\
\hline
\end{tabular}

C. Number of Observations Used for Calculattng the Daily Mean

\begin{tabular}{|c|c|c|c|c|c|}
\hline Mean tioess & $\mid \begin{array}{c}\text { Mean prossuro } \\
\text { (Pertod) }\end{array}$ & $\begin{array}{c}\text { Temperature } \\
\text { (Period) }\end{array}$ & $\begin{array}{l}\text { Relative } \\
\text { humidtty } \\
\text { (Period) }\end{array}$ & $\begin{array}{l}\text { Cloud } \\
\text { (Perlod) }\end{array}$ & $\begin{array}{l}\text { Wind } \\
\text { (Period) }\end{array}$ \\
\hline $\begin{array}{l}3(5,13,21) \\
6(2,6,10) \\
14,18,22) \\
24(1-24) \\
4(1,7, \\
13,19) \\
4(2,8,\end{array}$ & \begin{tabular}{|l}
$1909-1935$ \\
$1936-1942$ \\
$1949-1950$ \\
$1951-1953$ \\
$1954.1-1960.6$ \\
$1960.7-1983$
\end{tabular} & $\begin{array}{l}1909-1935 \\
1936-1942 \\
1949-1950 \\
1951-1953 \\
1954.1-1960.6\end{array}$ & $\mid$\begin{tabular}{l|}
$1909-1935$ \\
$1936-1942$ \\
$1949-1950$ \\
$1951-1953$ \\
$1954.1-1960.6$
\end{tabular} & $\mid \begin{array}{l}1951-1953 \\
1954.1-1960.6\end{array}$ & $\begin{array}{l}1951-1953 \\
1954.1-1960.6 \\
1960.7-1983\end{array}$ \\
\hline
\end{tabular}

D. Remariks:

1. O1d name:" Benjiang ". 
A. Main Data Sources
1. $1951.8-1980$
2. $1981-1983$
3. 1951.8-12 (Mean temperature, dominast winds
1951.9-12 (Precitation)
and meen wind speed)
(12)
(12)

3. Location of Station, Time Standard and Times of Observation

\begin{tabular}{|c|c|c|c|c|c|c|}
\hline $\begin{array}{l}\text { Observational } \\
\text { period }\end{array}$ & Adidress & $\mid \begin{array}{l}\text { Locat10n } \\
\text { Lat.N }\end{array}$ & $\begin{array}{l}\text { of stat } \\
\text { Lol.E }\end{array}$ & $\begin{array}{l}t \pm 00 \\
\mid \mathrm{B}(\mathrm{M})(\mathrm{PB})\end{array}$ & $\begin{array}{l}\text { Ifme Zone } \\
\text { system }\end{array}$ & $\begin{array}{c}\text { Times of } \\
\text { observations }\end{array}$ \\
\hline $1951.8-1953.22$ & Airport & $\left|43^{\circ} 55^{\prime}\right|$ & $81^{\circ} 17^{\prime}$ & 670.0 & (BoijtIng & $\begin{array}{r}8(3,6,9,12,14 \\
18,21,24)\end{array}$ \\
\hline $1954.1-12$ & Airport & $43^{\circ} 55^{\prime}$ & $81^{\circ} 17^{\prime}$ & 670.0 & 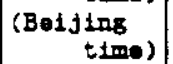 & $\begin{array}{l}4(4,10,16,22) \\
4(3,9,15,21)\end{array}$ \\
\hline $1955.1-1957.9$ & Alrport & $43^{\circ} 55^{\prime}$ & $81^{\circ} 17^{\prime}$ & 670.0 & $\begin{array}{c}(B 01 j \pm 178 \\
t 100)\end{array}$ & $4(1,7,13,19)$ \\
\hline 1957.10 & Atrport & $43^{\circ} 57^{\circ}$ & $81^{\circ} 20^{\circ}$ & 662.5 & $\begin{array}{c}(801 j \pm \sin \\
t \leq 0)\end{array}$ & $4(1,7,13,19)$ \\
\hline $1957.11-60.7$ & Atrport & $43^{\circ} 55^{\circ}$ & $81^{\circ} 17^{\prime}$ & 664.0 & $\begin{array}{c}\text { (Boijting } \\
\text { t垷e) }\end{array}$ & $4(1,7,13,19)$ \\
\hline $1960.8-61.12$ & Airport & $43^{\circ} 55^{\circ}$ & $81^{\circ} 17^{\circ}$ & 663.0 & 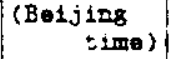 & $4(2,8,14,20)$ \\
\hline $2962-1983$ & Alrport & $43^{\circ} 57^{\prime}$ & $81^{\circ} 20^{\prime}$ & 662.5 & 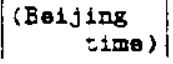 & $4(2,8,14,20)$ \\
\hline
\end{tabular}

C. Number of Observations Used for Calculating the Daily Mean

\begin{tabular}{|c|c|c|c|c|c|c|}
\hline Mean times & $\mid \begin{array}{c}\text { Mean pressure } \\
\text { (Pertod) }\end{array}$ & $\left\{\begin{array}{c}\text { Temperature } \\
\text { (Pertod) }\end{array}\right.$ & $\begin{array}{l}\text { Relative } \\
\text { humidity } \\
\text { (Period) }\end{array}$ & $\begin{array}{l}\text { Cloud } \\
\text { (Period) }\end{array}$ & $\begin{array}{l}\text { Wind } \\
\text { (Period) }\end{array}$ & $\begin{array}{c}\text { Precipitation } \\
\text { (Period) }\end{array}$ \\
\hline $\begin{array}{c}8(3,6,9, \\
12,14, \\
18,21,24) \\
4(4,10, \\
16,22) \\
4(3,9,15\end{array}$ & $1951.8-53.12$ & $1951.8-53.12$ & $\left\{\begin{array}{l}1951.8-53.12 \\
1954\end{array}\right.$ & $(1951.8-53.12\}$ & $1951.8-53.12$ & $\begin{array}{l}1954 \\
1954\end{array}$ \\
\hline $4(1,7)$ & $1955.1-60.7$ & $1955.1-60.7$ & $1955.1-60.7$ & $1955.1-60.7$ & $1955.1-60.7$ & $1955.1-60.7$ \\
\hline $\begin{array}{r}4(2,8, \\
\vdots 4,20)\end{array}$ & $1960.8-1983$ & $1960.8-1983$ & $1960.8-1983$ & $1960.8-1983$ & $1960.8-1983$ & $1960.8-1983$ \\
\hline
\end{tabular}

D. Remarks : 
No. 751463 Wu Lu Mu Qi

A. Main Data Sources

$\begin{array}{lc}\text { 1. } 1907-1940 & (1)(3) \\ \text { 2. } 1941-1950 & (25) \\ \text { 3. } 1951-1980 & (26) \\ \text { 4. } 1981-1983 & (13) \\ \text { 5. } 1951.1-3 \text { (dominant winds) } & (12) \\ 1954.1-6 \text { (moan wind spoed) } & \text { (12) }\end{array}$

B. Location of Station, Time Standard and Times of Observation

\begin{tabular}{|c|c|c|c|c|c|c|}
\hline $\begin{array}{c}\text { Observationai } \\
\text { period }\end{array}$ & Address & $\left|\begin{array}{l}\text { Location } \\
\text { Lut.N }\end{array}\right|$ & $\begin{array}{l}\text { a of stat } \\
\mid \text { LoN.E }\end{array}$ & $\begin{array}{l}t \neq 0 \text {. } \\
\mid \mathrm{E}(\mathrm{M}) \text { (EH) }\end{array}$ & $\mid \begin{array}{c}\text { Time Zono } \\
\text { systen }\end{array}$ & $\begin{array}{c}\text { Times of } \\
\text { observations }\end{array}$ \\
\hline $\begin{array}{l}1907-1908 \\
1910-1911 \\
1930-1931 \\
1941-1945 \\
1945-1950 \\
1951.1-12\end{array}$ & $\begin{array}{l}\text { Southerm } \\
\text { gate }\end{array}$ & $\left|\begin{array}{ll}43^{\circ} & 52^{\prime} \\
43^{\circ} & 45^{\prime} \\
43^{\circ} & 47^{\prime}\end{array}\right|$ & $\left|\begin{array}{ll}87^{\circ} & 36^{\prime} \\
87^{\circ} & 40^{\circ}\end{array}\right|$ & $\begin{array}{l}905.0 \\
915.0\end{array}$ & $\begin{array}{l}90^{\circ} \text { E.M.I } \\
90^{\circ} \text { E.M.I }\end{array}$ & $\begin{array}{l}3(7,13,21) \\
3(7,14,21) \\
4(1,7,13,19)\end{array}$ \\
\hline $\begin{array}{l}1952.1-5 \\
1952.6-53.12\end{array}$ & $\begin{array}{l}\text { (in city) } \\
\text { As above } \\
\text { As above }\end{array}$ & $\begin{array}{l}43^{\circ} 47^{\prime} \\
43^{\circ} 47\end{array}$ & $\left|87^{\circ} 37^{\circ}\right|$ & $\begin{array}{l}909.0 \\
902.7\end{array}$ & $\begin{array}{l}90^{\circ} \text { E.M.T } \\
90^{\circ} \text { E.M.T }\end{array}$ & $\begin{array}{l}24(1-24) \\
8(3,6,9,12, \\
14,18,21,24)\end{array}$ \\
\hline $1954.1-55.12$ & As above & $43^{\circ} 47^{\circ}$ & $87^{\circ} 37^{\prime}$ & 912.6 & $\begin{array}{l}\text { Local mean | } \\
\text { solar time }\end{array}$ & $4(1,7,13,19)$ \\
\hline $1956.1-58.3$ & As above & $43^{\circ} 47^{\prime}$ & $87^{\circ} 37^{\prime}$ & 911.6 & $\begin{array}{l}\text { Local maan } \\
\text { solar tifre }\end{array}$ & $4(1,7,13,19)$ \\
\hline $1958.4-1960.10$ & As above & $43^{\circ} 49^{\prime}$ & $87^{\circ} 33^{\circ}$ & 850.5 & $\begin{array}{l}\text { Local maen } \\
\text { solar time }\end{array}$ & $4(1,7,13,19)$ \\
\hline $1960.11-1975.12$ & $\begin{array}{l}\text { Western } \\
\text { suburb } \\
\text { asrport }\end{array}$ & $43^{\circ} 54^{\prime}=$ & $87^{\circ} 28^{\prime}$ & 653.5 & 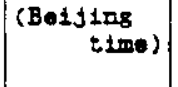 & $4(2,8,14,20)$ \\
\hline $1976.1-1983$ & $\begin{array}{c}\text { Southern } \\
\text { gate }\end{array}$ & $43^{\circ} 47^{\circ}$ & $87^{\circ} 37^{\prime}$ & 917.9 & 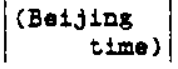 & $4(2,8,14,20)$ \\
\hline
\end{tabular}

C. Number of observations used for calculating the delly mean

\begin{tabular}{|c|c|c|c|c|c|}
\hline Mean times & $\mid \begin{array}{c}\text { Mean pressure } \\
\text { (Period) }\end{array}$ & $\mid \begin{array}{c}\text { Temperature } \\
\text { (Period) }\end{array}$ & $\begin{array}{l}\text { Relative } \\
\text { humidity } \\
\text { (Period) }\end{array}$ & $\begin{array}{l}\text { Cloud } \\
\text { (Period) }\end{array}$ & $\begin{array}{l}\text { Wind } \\
\text { (Period) }\end{array}$ \\
\hline $\begin{array}{l}3(7,13,21) \\
3(7,14,21) \\
24(1-24) \\
4(1,7,13,19) \\
4(2,8,14,20)\end{array}$ & $\left\{\begin{array}{l}1907-1908 \\
1910-1911.6 \\
1951-1953 \\
1954-1960.7 \\
1960.7-1983\end{array}\right.$ & \begin{tabular}{|l|}
$1907-1908$ \\
$1910-19111.6$ \\
$1930-1931.5$ \\
$1951-1953$ \\
$1954-1960.7$ \\
$1960.7-1983$
\end{tabular} & $\begin{array}{l}1951-1953 \\
1954-1960.7 \\
1960.7-1983\end{array}$ & $\begin{array}{l}1954-1960.7 \\
1960.7-1983\end{array}$ & $\mid \begin{array}{l}1954-1960.7 \\
1960.8-1983\end{array}$ \\
\hline
\end{tabular}

D. Remarixs:

1. Old name: "Di Bua "

2. Station has moved stx ttmes since 1950.

3. There was a large change of position and elevation during 1960.11-1975.12. 
A. Main Data Sources
$\therefore$ 1951-1980
2. $1981.1-1983$
(13)
3. $1951.1-3$ (dominant pinds)
1953.8-9
1954.1-2,10-12 (Mean pressure)

B. Location of Station, Iime Standard and Iimes of Observation

\begin{tabular}{|c|c|c|c|c|c|c|c|}
\hline $\begin{array}{l}\text { Observational } \\
\text { period }\end{array}$ & Address & $\begin{array}{l}\text { Location } \\
\text { Lat.N }\end{array}$ & $\begin{array}{l}\text { of stat } \\
\text { LoN.E }\end{array}$ & $|E(M)(P H)|$ & $\begin{array}{c}\text { Tisos } \\
\text { syst }\end{array}$ & 2000 & $\begin{array}{c}\text { Times of } \\
\text { observations }\end{array}$ \\
\hline $1951.1-1953.12$ & & $42^{\circ} 50^{\circ}$ & $93^{\circ} 27^{\prime}$ & 770.0 & $t \pm m e$ & Zone & $8(3,6,9,12$, \\
\hline $1954.1-1957.1$ & & $42^{\circ} 50^{\prime}$ & $93^{\circ} 27^{\circ}$ & 735.0 & $\begin{array}{l}\text { Local } \\
\text { solar }\end{array}$ & $\begin{array}{l}\operatorname{mean} \\
\text { time }\end{array}$ & $\begin{array}{l}4(4,10,16,22) \\
4(3,9,15,21)\end{array}$ \\
\hline $1957.2-1957.6$ & & $42^{\circ} 50^{\circ}$ & $93^{\circ} 27^{\prime}$ & 784.2 & $\begin{array}{l}\text { Local } \\
\text { solar }\end{array}$ & mean & $4(1,7,13,19)$ \\
\hline $1957.7-1959.8$ & & $42^{\circ} 50^{\circ}$ & $93^{\circ} 27^{\prime}$ & 767.0 & $\begin{array}{l}\text { Local } \\
\text { solar }\end{array}$ & $\begin{array}{l}\text { mean } \\
\text { time }\end{array}$ & $4(1,7,13,19)$ \\
\hline $1959.9-1960.6$ & & $42^{\circ} 50^{\circ}$ & $93^{\circ} 27^{\prime}$ & 737.9 & $\begin{array}{l}\text { Local } \\
\text { solar }\end{array}$ & $\begin{array}{l}\operatorname{moan} \\
\text { time }\end{array}$ & $4(1,7,13,19)$ \\
\hline $1960.7-1962.6$ & & $42^{\circ} 50^{\circ}$ & $93^{\circ} 27^{\circ}$ & 737.9 & (Betj) & $\begin{array}{l}108 \\
t \pm 0(8)\end{array}$ & $4(2,8,14,20)$ \\
\hline $1962.7-1983$ & & $42^{\circ} 49^{\prime}$ & $93^{\circ} 31^{\prime}$ & 737.9 & (Betj & $\begin{array}{l}\operatorname{ling} \\
\operatorname{tin} \theta\end{array}$ & $4(2,8,14,20)$ \\
\hline
\end{tabular}

c. Number of Observations Used for Calculating the Datly Mean

\begin{tabular}{|c|c|c|c|c|}
\hline Mean times & $\begin{array}{c}\text { Mean pressure } \\
\text { (Perjod) }\end{array}$ & $\begin{array}{l}\text { Temperature } \\
\text { (Period) }\end{array}$ & $\mid \begin{array}{c}\text { Relative humidtty } \\
\text { (Feriod) }\end{array}$ & $\left\{\begin{array}{c}\text { Wind } \\
\text { (Perlod) }\end{array}\right.$ \\
\hline $\begin{array}{l}8(3,6,9,12, \\
14,18,21,24) \\
4(4,10,16,22) \\
4(3,9,15,21)\end{array}$ & $1951-1953$ & $\begin{array}{l}1951-1953 \\
1954\end{array}$ & $\begin{array}{l}1951-1953 \\
1954\end{array}$ & $1951-1953$ \\
\hline $\begin{array}{l}4(1,7,13,19) \\
4(2,8,14,20)\end{array}$ & $\begin{array}{l}1955.1-1960.7 \\
1960.8-1983\end{array}$ & $\begin{array}{l}1955.1-1960.7 \\
1960.8-1983\end{array}$ & $\begin{array}{l}1955.1-1960.7 \\
1960.8-1983\end{array}$ & $\begin{array}{l}1954 \\
1955.1-1960.7 \\
1960.8-1983\end{array}$ \\
\hline
\end{tabular}

ב. Remarks: 
A. Main Data Sources

$\begin{array}{ll}\text { 1. } 1934.7-1950.12 & (28) \\ \text { 2. } 1951-1969.12 & (29) \\ \text { 3. } 1970 \text { (wind, sueshire, and precipitation) } & (7)(9)(10) \\ \text { 4. } 1971-1980 & (30) \\ \text { 5. } 1934.7-1970 \text { (Mean pressure, temperature, } & \\ \text { b. } 1981-1983 & (31) \\ \text { 7. } 1934-1936 \text { (cloud amounts and dominant winds) } & (13) \\ \text { 8. } 1951-1962,1971-1980 \text { (Total amoumt of cloud) } & (15) \\ & 1963-1970 \text { (Total amount of cloud) }\end{array}$

B. Location of Station, Tlme Standard and Iimes of Observation

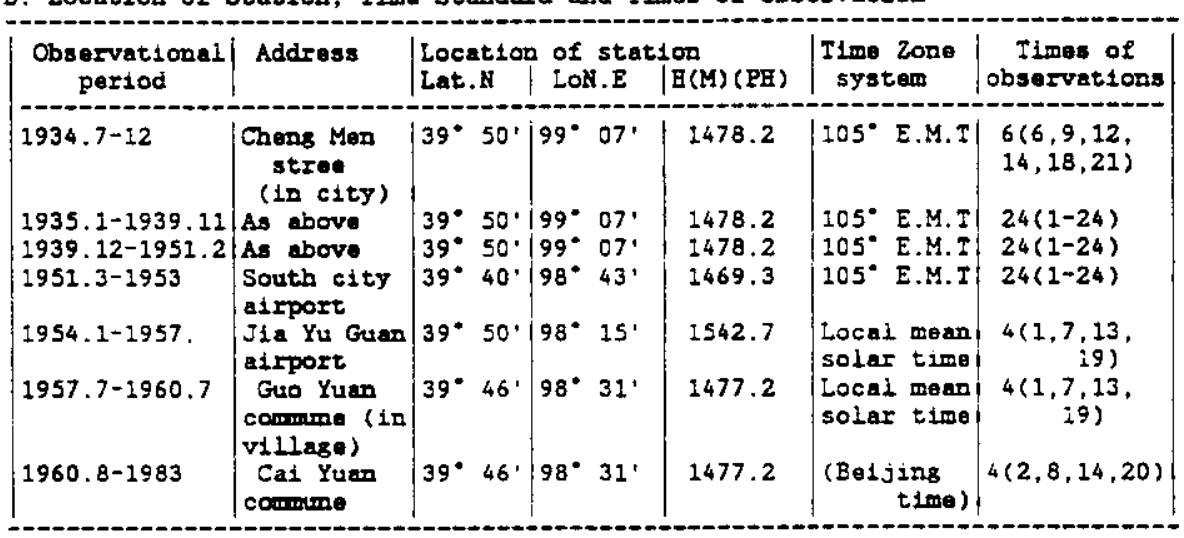

C. Number of Observations Used for Calculating the Daily Mean

\begin{tabular}{|c|c|c|c|c|}
\hline Mean times & $\begin{array}{c}\text { Mean preseure } \\
\text { (Pertod) }\end{array}$ & $\begin{array}{c}\text { Temperaturo } \\
\text { (Period) }\end{array}$ & $\begin{array}{l}\text { Relative humidity } \\
\text { (Period) }\end{array}$ & $\begin{array}{l}\text { Wind } \\
\text { (Period) }\end{array}$ \\
\hline $\begin{array}{l}3(6,14,21) \\
24(1-24) \\
4(1,7,: 3,19) \\
4(2,8,14,20)\end{array}$ & & $\begin{array}{l}1934-1936.10 \\
1937-1953 \\
1954-1960.7 \\
1960.8-1983\end{array}$ & $\begin{array}{l}1934-1936.10 \\
1937-1953 \\
1954-1960.7 \\
1960.8-1983\end{array}$ & $\begin{array}{l}1957.7-1960.7 \\
1960.8-1983\end{array}$ \\
\hline
\end{tabular}

D. Remariss: 


\section{B-12}

No. $10 \quad 52652$ Zhang Ye

A. Mair Data Sources

$\begin{array}{lc}\text { 2. } 1937-1950 & (37) \\ \text { 2. } 1951-1969 & (38) \\ \text { 3. } 1970 \text { (wind, precipitation, and sunstine) } & (7)(9)(10) \text { ) } \\ \text { 4. } 1951-1970 \text { (pressure, temperature, } & \\ \text { 5. } 1971-1980 & \text { humidity, and snow days) } \\ \text { 6. } 1981-1983 & (39) \\ \text { 7. } 1951-1962 \text { (total cloud amount) } & (13) \\ 1963-1970 \text { (totai cloud amount) } & (12)\end{array}$

B. Location of Station, Time Standard and Times of Observation

\begin{tabular}{|c|c|c|c|c|c|c|c|}
\hline $\begin{array}{l}\text { Observational } \\
\text { period }\end{array}$ & Addres: & $\begin{array}{l}\text { Locat 1 on } \\
\text { Lat. N }\end{array}$ & $\begin{array}{l}\text { of statt } \\
\text { LoN.E }\end{array}$ & $\begin{array}{l}\text { ton } \\
E(\mathrm{Y})(\mathrm{FE})\end{array}$ & $\mid \begin{array}{c}\text { Time } \\
\text { syate }\end{array}$ & Zone & $\begin{array}{c}\text { Tfmes of } \\
\text { observations }\end{array}$ \\
\hline 1937-1939 & $\begin{array}{l}\text { Soutbeast } \\
\text { stde of city } \\
\text { (suburb) }\end{array}$ & $38^{\circ} 56^{\prime} \mid$ & $100^{\circ} 37^{\circ} \mid$ & & & & $4(6,9,14,21)$ \\
\hline $\begin{array}{l}1940-1941 \\
1951-1953\end{array}$ & $\begin{array}{l}\text { As above } \\
\text { Big Man Bao } \\
\text { South (coun- } \\
\text { tryside) }\end{array}$ & $\mid \begin{array}{ll}38^{*} & 56^{\prime} \\
38^{\circ} & 55^{\prime}\end{array}$ & $\begin{array}{l}100^{\circ} 37^{\circ} \\
100^{\circ} \\
35^{\circ}\end{array}$ & 1550.0 & $\begin{array}{l}\text { Local } \\
205^{\circ} \mathrm{B}\end{array}$ & E.M.I & $\begin{array}{r}3(6,14,22) \\
8(3,6,9,12, \\
18,21,24)\end{array}$ \\
\hline $1954-1955.3$ & As a & $38^{\circ} 55^{\prime}$ & $100^{\circ} 35^{\prime}$ & 1550.0 & $\begin{array}{l}\text { Local } \\
\text { solar }\end{array}$ & $\begin{array}{l}\text { meani } \\
\text { timei }\end{array}$ & i 42 . \\
\hline $2955.4-1959.7$ & $\begin{array}{l}\text { "Long Gong } \\
\text { Templo" the } \\
\text { out of small } \\
\text { south gate }\end{array}$ & $38^{\circ} 56^{\circ}$ & $100^{\circ} 35^{\circ}$ & 1479.5 & $\begin{array}{l}\text { Local } \\
\text { solar }\end{array}$ & $\begin{array}{l}\text { meani } \\
\text { tima }\end{array}$ & \\
\hline $1959.8-1980.7$ & $\begin{array}{l}\text { Westerre gate } \\
\text { out (stiburb) }\end{array}$ & $38^{\circ} 56^{\circ}$ & $100^{\circ} 35^{\prime}$ & 1468.5 & $\begin{array}{l}\text { Local } \\
\text { solar }\end{array}$ & $\mid \begin{array}{l}\text { mean } \\
\text { t1me }\end{array}$ & $4(1,7,13,19)$ \\
\hline $1960.8-1962$ & As above & $38^{\circ} 56^{\circ}$ & $100^{\circ} 35^{\prime}$ & 1468.5 & (Boijt & $\begin{array}{l}1 \pi .8 \\
\operatorname{tin} \theta)\end{array}$ & $4(2,8,14,20)$ \\
\hline $1963-1983$ & As above & $38^{\circ} 56^{\circ}$ & $100^{\circ} 35^{\prime}$ & 1483.9 & (BeIj1 & $\begin{array}{l}\operatorname{lng} \\
t \pm 0\end{array}$ & $4(2,8,14,20)$ \\
\hline
\end{tabular}

C. Number of Observations Used for Calculating the Datly Mean

\begin{tabular}{|c|c|c|c|}
\hline Mean times & $\begin{array}{l}\text { Tetroperature } \\
\text { (Period) }\end{array}$ & $\mid \begin{array}{c}\text { Relative humidity } \\
\text { (Pertod) }\end{array}$ & $\begin{array}{l}\text { Wind } \\
\text { (Pertod) }\end{array}$ \\
\hline $\begin{array}{l}3(6,14,21) \\
8(3,6,9,12,14 \\
18,21,24)\end{array}$ & $\begin{array}{l}1937.4-1941 \\
1951-1953\end{array}$ & $\begin{array}{l}1937.4-1941 \\
1951-1953\end{array}$ & $1951-1953$ \\
\hline $\begin{array}{l}4(1,7,13,29) \\
4(2,8,24,20)\end{array}$ & $\begin{array}{l}1954-1960.7 \\
: 960.8-\text { now }\end{array}$ & $\begin{array}{l}1954-1960.7 \\
2960.8-\text { now }\end{array}$ & $\begin{array}{l}1954-1960.7 \\
1960.8-\text { now }\end{array}$ \\
\hline
\end{tabular}

\section{Rewarixs:}

\footnotetext{
2. Date divided time: 22 local time during 1937-1941

$24105^{\circ} \mathrm{E}$ mean time during $1951-1953$

19 local mean solar time (L.M.S.T) during 1954-1960.7

20 Betjing time durting 1960.8-1983
} 


\section{No. $1152866 \quad$ Xi NiEf}

一. Main Data Sourees

1. $1936-1949$

2. $1951.2-1953$

3. $1954.1-1970$

4. $1981-1983$

5. 1961-1970 (Totai amoun: oí ciouc 1951-1953 [Snow days!

1951-1954 (Dominas: anc corninan: nin: iteoueres
Vumioe of Data:

$(1)(3)(5)(4:$

(12)

(32)

132

(156:

$(156)$

(156)

=. List of location of station. time stanciarc and times of observation

\begin{tabular}{|c|c|c|c|c|c|c|}
\hline \multirow{2}{*}{$\begin{array}{l}\text { Ooservatuonai } \\
\text { period }\end{array}$} & \multirow{2}{*}{ Addres } & \multicolumn{3}{|c|}{ Location of statior: } & \multirow{2}{*}{$\begin{array}{c}\text { Tume Zone } \\
\text { syster. }\end{array}$} & \multirow{2}{*}{$\begin{array}{c}\text { Times of } \\
\text { ouservation }\end{array}$} \\
\hline & & La:N & LONEE & $\mathrm{H}(\mathrm{M})(\mathrm{PH}:$ & & \\
\hline $1936-1949$ & & $26^{\circ} 1^{-1}$ & $101^{\circ} 49^{\circ}$ & 227.5 & & \\
\hline $1951-1952.6$ & & $36^{\circ} 35^{\prime}$ & $101^{\circ} 55^{\prime}$ & 2296.0 & & \\
\hline $1952.7-1953.12$ & & $36^{\circ} 35^{\prime}$ & $101^{\circ} 55^{\prime}$ & 2295.9 & E.M.T & $\begin{array}{l}8(3,6.9 .12 \\
i 4.18 .21 .24)\end{array}$ \\
\hline $1954.1-8$ & Small brioge of xi Ning & $36^{\circ} 35^{\prime}$ & $101^{\circ} 55^{\prime}$ & 2231.1 & Local time & $: 4(1,7.13,19)$ \\
\hline $1954.9-1960.7$ & No. I: $\$ 4$ strec: & $36^{\circ} 35^{\prime}$ & $101^{\circ} 55^{\prime}$ & 2261.2 & laz:: :irr & $\therefore: \ldots 12+0 !$ \\
\hline $1960.8-1973.12$ & No.7: 54 stres: & $36^{\circ} 35^{\prime}$ & $101^{\circ} 55^{\prime}$ & 2261.2 & $\begin{array}{c}\text { (aime) } \\
\text { time) }\end{array}$ & $4(2.8,14,20)$ \\
\hline $1974.1-1983$ & No.?:54 & $30 \cdot 37$ & $101^{\circ} 46^{\circ}$ & $2261 .=$ & $\begin{array}{c}\text { (Beijing } \\
\text { time) }\end{array}$ & $4(2,8,14,20)$ \\
\hline
\end{tabular}

E. Number of Ooservatuons Used for Caicuiatung the Dailv Mear.

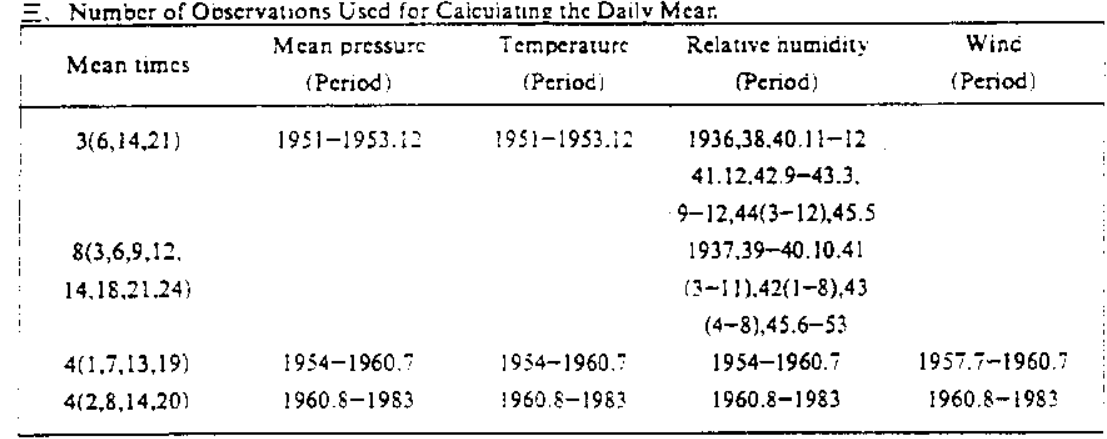

I. Remarks colurar: 
B-14

:ง. 2252889 Lan Zhou

A. Main Data Sources

$\begin{array}{ll}\text { i. } 1932.6-1950 & (33)(34) \\ \text { z. } 1951-1969 & (35) \\ \text { 3. } 1932-1970 & (31) \\ \text { 4. } 1970 \text { (wind, p=ecipitation, and sunshine) } & (7)(9)(10) \\ \text { 5. } 1971-1980 & (36) \\ \text { 5. } 1981-1983 \text { (moan wind spoed) } & (13) \\ \text { 7. } 1933-1936 \text { (mean } & (15) \\ 1934-1936 \text { (dominant winds) } & \\ \text { 8. } 1951-1962 \text { (cloud amount) } & (12) \\ 1963-1970 \text { (cloud amount) } & (156)\end{array}$

3. Location of Station, Time Standard and Times of Observation

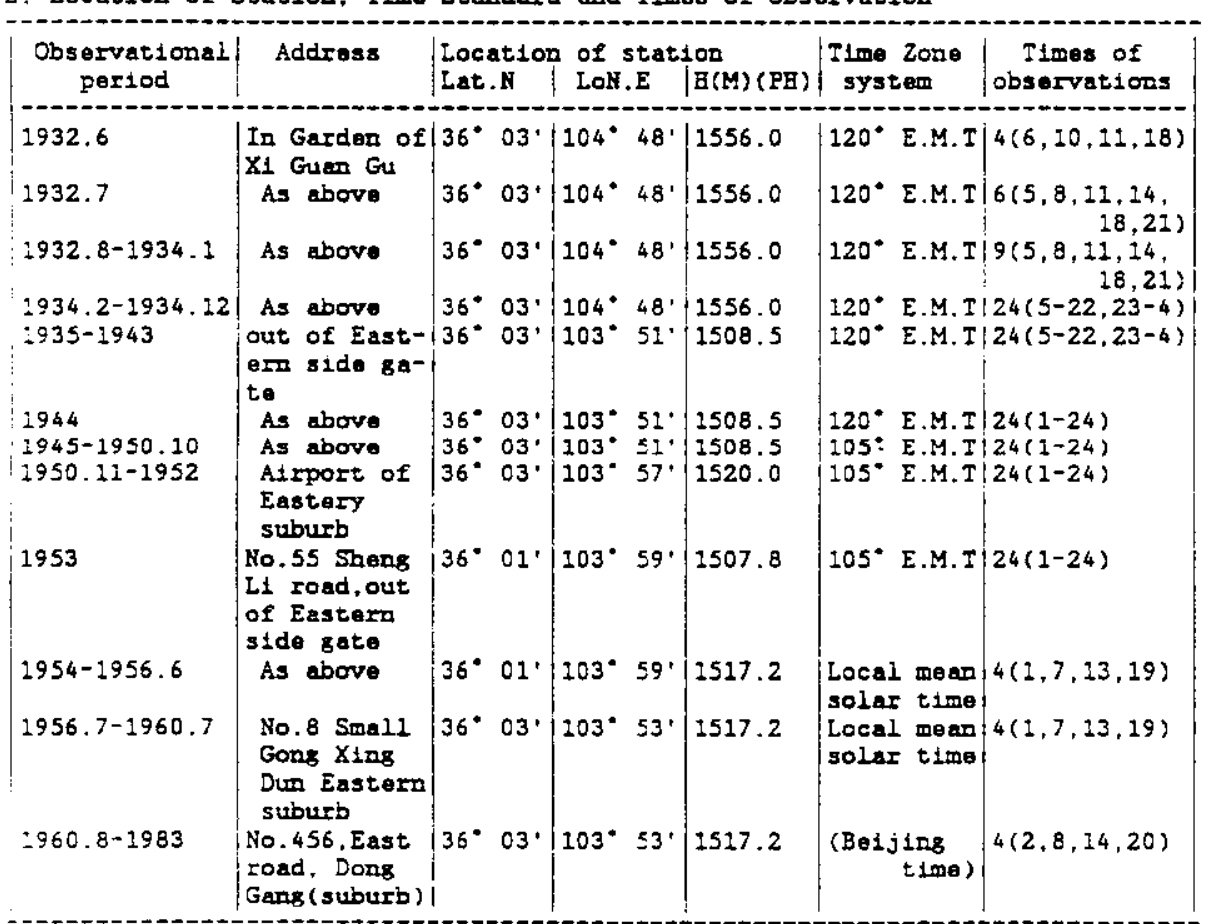

₹. Simber of Observarions Used for Calculating the Daily Mean

\begin{tabular}{|c|c|c|c|c|}
\hline Mean times & $\begin{array}{l}\text { iMean pressure } \\
\text { (Period) }\end{array}$ & $\begin{array}{c}\text { Temperature } \\
\text { (Period) }\end{array}$ & $\left|\begin{array}{c}\text { Relative humidity } \\
\text { (Period) }\end{array}\right|$ & $\begin{array}{l}\text { Wind } \\
\text { (Period) }\end{array}$ \\
\hline $\begin{array}{l}24(1-24) \\
4(1,7,13,19) \\
4(2,8,14,20)\end{array}$ & $\begin{array}{l}1932.6-1947 \\
1948-1953 \\
1954-1960.7 \\
1960.8-1969\end{array}$ & $\begin{array}{l}1932.6-1934.1 \\
1934.2-1953 \\
1954-1960.7 \\
1960.8-1983\end{array}$ & $\begin{array}{l}1932.6-1934.1 \\
1934.2-1953 \\
1954-1960.7 \\
1960.8-1983\end{array}$ & $\begin{array}{l}1957.7-1960.7 \\
1960.8-1983\end{array}$ \\
\hline
\end{tabular}

2. Remariks:

1. Date divided time: $22120^{\circ} \mathrm{E}$ mean time during 1932-1945

$24105^{\circ} \mathrm{E}$ mean time during $1946-1953$

ig local mean solar time (L.M.S.T.) during 1954-1960.7

20 Beijing time during 1960.8-1983

2. In 24 times observations, data are from autographic records for the period 23 p.m.to 4 a.th. 


\section{B-15}

A. Main Data Sources
1. $1920-1950$
(40)
2. $1951-1980$
(41)
3. $1981-1983$
(13)

B. Location of Station, TIme Standard and Times of Observation

\begin{tabular}{|c|c|c|c|c|c|c|}
\hline $\begin{array}{c}\text { Observational } \\
\text { period }\end{array}$ & Address & $\left|\begin{array}{l}\text { Locat tog } \\
\text { Lat.N }\end{array}\right|$ & $\left|\begin{array}{l}\text { of stat: } \\
\text { LON.E }\end{array}\right|$ & $\begin{array}{l}\mathrm{F} \\
E(\mathrm{M})(\mathrm{MR})\end{array}$ & $\begin{array}{c}\text { T1an Zone } \\
\text { system }\end{array}$ & $\begin{array}{c}\text { Times of } \\
\text { observations }\end{array}$ \\
\hline $1920-1947.3$ & $\begin{array}{l}\text { Gut Sui Shi } \\
\text { Da Tai Shen } \\
\text { Cat agficu- } \\
\text { lture school }\end{array}$ & $40^{\circ} \quad 48^{\prime} \mid$ & $\left|111^{\circ} 38^{\circ}\right|$ & 1035.0 & $120^{\circ}$ E.M.I & $3(6,14,21)$ \\
\hline $\begin{array}{l}1947.4-1950 \\
1951-1953\end{array}$ & $\begin{array}{l}\text { As above } \\
\text { Now city } 02 \\
\text { Gul Stit East } \\
\text { gate out a1- }\end{array}$ & $\mid \begin{array}{ll}40^{\circ} & 48^{\prime} \\
40^{\circ} & 49^{\prime}\end{array}$ & $\begin{array}{l}111^{\circ} \\
111^{\circ} \\
41^{\prime}\end{array}$ & $\begin{array}{l}1035.0 \\
1062.2\end{array}$ & $\begin{array}{l}105^{\circ} \text { E.M.I } \\
105^{\circ} \text { E.M.I }\end{array}$ & $\begin{array}{r}3(6,14,21) \\
8(3,6,9,12 \\
18,21,24)\end{array}$ \\
\hline $1954-1960.7$ & As above & $40^{\circ} 49^{\circ}$ & $111^{\circ} 41^{\prime}$ & 1062.2 & $\begin{array}{l}\text { Local mean } \\
\text { solar time }\end{array}$ & $4(1,7,13,19)\}$ \\
\hline $1960.8-1983$ & As above & $40^{\circ} 49^{\circ}$ & $111^{\circ} 41^{\prime}$ & 1063.0 & (Be1jing & $4(2,8,14,20)$ \\
\hline
\end{tabular}

C. Number of Observations Used for Calculating the Dafly Meen

\begin{tabular}{|c|c|c|c|}
\hline Mean times & $\begin{array}{c}\text { Mean pressure } \\
\text { (Porlod) }\end{array}$ & $\begin{array}{c}\text { Temperature } \\
\text { (Period) }\end{array}$ & $\left|\begin{array}{c}\text { Relat:ve humidtty } \\
\text { (Period) }\end{array}\right|$ \\
\hline $\begin{array}{l}4(1,7,13,19) \\
4(2,8,14,20)\end{array}$ & $\begin{array}{l}1947-1950 \\
1951-1953 \\
\\
1954-1960.7 \\
1960.8-1983\end{array}$ & $\begin{array}{l}1930-1937 \\
1939-1943 \\
1946-1950 \\
1954-1960.7 \\
1960.8-1983\end{array}$ & $\begin{array}{l}1934-1936 \\
1947-1950 \\
1951-1953 \\
1954-1960.7 \\
1960.8-1983\end{array}$ \\
\hline
\end{tabular}

D. Remariks :

1. Date divided time: $21105^{\circ} \mathrm{E}$ meridian time before 1951 year

$24105^{\circ} \mathrm{E}$ mer1ditan time during 1951-1953

19 local solar time (L.M.S.T.) during 1954-1960.7

20 Beijtrg time durins 1960.8-1983

2. Minimim temperature for 1955.5, and sunshine bours and cloud amounts for 1951-1980 were estimated.

3. Old name: Gui Sui 
A. Main Data Sources
1. $1935-1938$
(1) (3)
2. $1951-1960$
(42)
3. $1951-1980$
(43)
4. $1981-1983$
5. 1951-1953 (mean wind speed)
(12)

B. Location of Station, Time Standard and Times of Observation

\begin{tabular}{|c|c|c|c|c|c|c|c|c|c|}
\hline $\begin{array}{c}\text { Observational } \\
\text { period }\end{array}$ & Address & $\begin{array}{l}\text { Loce } \\
\text { Lat. }\end{array}$ & $N$ & i of & $\begin{array}{l}\text { stat } \\
. E\end{array}$ & $\begin{array}{l}\text { ton } \\
|\mathrm{E}(\mathrm{M})(\mathrm{EH})|\end{array}$ & $\begin{array}{c}T \pm m e \\
\text { syst }\end{array}$ & Zone & $\begin{array}{c}\text { I1ones of } \\
\text { observations }\end{array}$ \\
\hline $\begin{array}{l}1935-1938 \\
1951.1-12\end{array}$ & $\begin{array}{l}\text { Western flow- } \\
\text { er garden of } \\
\text { mew city } \\
\text { ( airport) }\end{array}$ & $\begin{array}{l}38^{\circ} \\
38^{\circ}\end{array}$ & $\begin{array}{l}28^{\prime} \\
25^{\prime}\end{array}$ & $\mid \begin{array}{l}106^{\circ} \\
107^{\circ}\end{array}$ & $\begin{array}{l}13^{\circ} \\
05^{\prime}\end{array}$ & $\mid \begin{array}{l}1065.0 \\
1125.0\end{array}$ & $\begin{array}{l}120^{\circ} \\
105^{\circ}\end{array}$ & $\begin{array}{l}\text { E.M.T } \\
\text { E.M.T }\end{array}$ & $\begin{array}{l}3(6,14,21) \\
3(6,14,21)\end{array}$ \\
\hline $1952.1-5$ & As above & $38^{\circ}$ & $25 !$ & $107^{\circ}$ & $20^{\prime}$ & 1115.0 & $105^{*}$ & E.M.T & $\left|\begin{array}{c}8(3,6,9,12,14 \\
18,21,24)\end{array}\right|$ \\
\hline $1952.6-11$ & As above & $38^{\circ}$ & $25^{\prime}$ & $107^{\circ}$ & $16^{\prime}$ & 1115.0 & $105^{*}$ & E.M.T & $\left|\begin{array}{c}8(3,6,9,12,14 \\
18,21,24)\end{array}\right|$ \\
\hline 1952.12 & As above & $38^{\circ}$ & $25^{\circ}$ & $107^{\circ}$ & $16^{\circ}$ & 1120.0 & $105^{\circ}$ & E.M.T & $\left|\begin{array}{c}8(3,6,9,12,14 \\
18,21,24)\end{array}\right|$ \\
\hline $1953.1-5$ & As above & $38^{\circ}$ & $25^{\circ}$ & $107^{\circ}$ & $16^{\prime}$ & 1115.0 & $: 05^{\circ}$ & E.M.I & $\left|\begin{array}{c}8(3,6,9,12,14 \\
18,21,24)\end{array}\right|$ \\
\hline$: 963.6-12$ & As above & $38^{*}$ & $25^{\circ}$ & $107^{\circ}$ & $26^{\circ}$ & 1101.3 & $225^{\circ}$ & E.M.T & $\mid \begin{array}{c}8(3,5,9,12,14 \\
18,21,24)\end{array}$ \\
\hline 1954.1 & As above & $38^{\circ}$ & $25^{\prime}$ & $107^{\circ}$ & $16^{\prime}$ & 1101.3 & $\begin{array}{l}\text { Local } \\
\text { solar }\end{array}$ & troano & $4(1,7,13,19)$ \\
\hline $1954.2-6$ & $\begin{array}{l}\text { New city } \\
\text { "Zhen Xiang } \\
\text { village" }\end{array}$ & $38^{\circ}$ & $25^{\prime}$ & $106^{\circ}$ & $16^{\prime}$ & 1115.0 & $\begin{array}{l}\text { Local } \\
\text { solar }\end{array}$ & mean & $4(1,7,13,19)$ \\
\hline $1954.7-1956.4$ & As above & $38^{\circ}$ & $25^{\prime}$ & $106^{\circ}$ & $16^{\circ}$ & 1111.5 & $\begin{array}{l}\text { Local } \\
\text { solar }\end{array}$ & $=\begin{array}{l}\text { menn } \\
\text { tione }\end{array}$ & $4(1,7,13,19)$ \\
\hline $1956.5-1960.7$ & As above & $38^{\circ}$ & $3 I^{\prime}$ & $106^{\circ}$ & $16^{\circ}$ & 1111.5 & $\begin{array}{l}\text { Local } \\
\text { solar }\end{array}$ & mean & $4(1,7,13,19)$ \\
\hline $1960.8-1971.2$ & As above & $38^{\circ}$ & $31^{\circ}$ & $106^{\circ}$ & $16^{\circ}$ & 1111.5 & (Beif & $\begin{array}{l}\operatorname{lng} \\
t \pm 0\end{array}$ & $4(2,8,14,20)$ \\
\hline $1971.2-1983$ & As above & $38^{\circ}$ & $29^{\prime}$ & $106^{\circ}$ & $13^{\circ}$ & $\begin{array}{l}1111.5 \\
(1112.2)\end{array}$ & (Beij) & ing & $4(2,8,14,20)$ \\
\hline
\end{tabular}

2. Number of Observations Used for Calculating the Daily Mean

\begin{tabular}{|c|c|c|c|c|}
\hline Mean times & $\begin{array}{c}\text { Mon pressure } \\
\text { (Poriod) }\end{array}$ & $\begin{array}{c}\text { Temperature } \\
\text { (Period) }\end{array}$ & $\mid \begin{array}{c}\text { Relative humidity } \\
\text { (Pertod) }\end{array}$ & $\begin{array}{l}\text { Wind } \\
\text { (Period) }\end{array}$ \\
\hline $\begin{array}{c}3(6, i 4,21) \\
s(3,6,9,12,14, \\
\vdots 9,21,24) \\
4(1,7,13,19) \\
4(2,8,14,20)\end{array}$ & $\begin{array}{l}1951.1-12 \\
1952.1-1953 \\
1954.1-1960.7 \\
1960.8-1983\end{array}$ & $\begin{array}{l}1935-1938 \\
1951.1-12 \\
1937-1953 \\
1952-1953 \\
1954.1-1960.7 \\
1960.8-1983\end{array}$ & $\begin{array}{l}1951.1-12 \\
1937-1953 \\
1952-1953 \\
1954.1-1960.7 \\
1960.8-1983\end{array}$ & $\begin{array}{l}1954.1-1960.7 \\
1960.8-1983\end{array}$ \\
\hline
\end{tabular}

כ. Remarks :

: Old name: "Sing Xia". 
A. Main Data Sources
1. Before 1950
2. $1951-1960$
3. $1961-1970$
4. $1971-1980$
5. $1981-1983$
6. $1961-1963$
1964-1970
7. 1971-1980 (dominant winds)
1971-1980 (snow deys)
$(1)(3)(4)$
(44)
$(6)(7)(8)(9)(10)(11)$
(159)
(13)
(12)
(156)
(156)

B. Location of Station. T1me Standiard and Iimes of Observation

\begin{tabular}{|c|c|c|c|c|c|c|}
\hline $\begin{array}{c}\text { Observational } \\
\text { period }\end{array}$ & Address & $\mid \begin{array}{l}\text { Location } \\
\text { Lat. }\end{array}$ & $\begin{array}{l}\text { of stati } \\
\text { LoN.E }\end{array}$ & $|\mathrm{E}(\mathrm{M})(\mathrm{FH})|$ & $\begin{array}{l}\text { T1me Zone } \\
\text { system }\end{array}$ & $\mid \begin{array}{c}\text { Tlmes of } \\
\text { observations }\end{array}$ \\
\hline $\begin{array}{l}1933-1950 \\
1951.1-2\end{array}$ & $\begin{array}{l}\text { Lu Second } \\
\text { pedagogical } \\
\text { school-up } \\
\text { alley }\end{array}$ & $\left|\begin{array}{ll}38^{\circ} & 17^{\prime} \\
38^{\circ} & 15^{\prime}\end{array}\right|$ & $\left|\begin{array}{ll}109^{\circ} & 45^{\circ} \\
209^{\circ} & 25^{\circ}\end{array}\right|$ & $\begin{array}{l}1120.7 \\
1094.2\end{array}$ & $\left|\begin{array}{l}120^{\circ} \text { E.M.I } \\
120^{\circ} \text { E.M.I }\end{array}\right|$ & $\left\{\begin{array}{l}3(6,14,21) \\
3(6,14,21)\end{array}\right.$ \\
\hline $\begin{array}{l}1951.3-11 \\
1951.12-1952.10\end{array}$ & $\begin{array}{l}\text { As above } \\
\text { No. 4-Lip all- } \\
\text { ey of Shens } \\
\text { L1 (10 c1Ey) }\end{array}$ & $\left|\begin{array}{ll}38^{*} & 15^{\prime} \\
38^{\circ} & 25^{\prime}\end{array}\right|$ & $\mid \begin{array}{ll}109^{\circ} & 25 \\
109^{\circ} & 25\end{array}$ & $\begin{array}{l}1094.2 \\
1094.2\end{array}$ & $\begin{array}{l}105^{\circ} \text { E.M.T } \\
105^{\circ} \text { E.M.T }\end{array}$ & $\begin{array}{l}3(6,14,21) \\
8(3,5,9,12, \\
14,18,21,24)\end{array}$ \\
\hline $1952.11-1953.12$ & $\begin{array}{l}\text { No.2. Middlo } \\
\text { alley of } \\
\text { Sheng Li }\end{array}$ & $38^{\circ} 15^{\prime}$ & $109^{\circ} 25^{\prime} \mid$ & 1094.2 & $205^{\circ}$ E.M.T & $\begin{array}{l}8(3,6,9,12, \\
14,18,21,24)\end{array}$ \\
\hline $\begin{array}{l}1954.1-3 \\
1954.4-1956.7\end{array}$ & $\begin{array}{c}\text { As above } \\
\text { Wei-Zo alley } \\
\text { mouth }\end{array}$ & $\mid \begin{array}{ll}38^{\circ} & 15^{\prime} \\
38^{\circ} & 15^{\circ}\end{array}$ & $\mid \begin{array}{ll}109^{\circ} & 25^{\prime} \\
109^{\circ} & 25\end{array}$ & $\begin{array}{l}1094.2 \\
1054.0\end{array}$ & Local time & $\mid \begin{array}{l}4(1,7,13,19) \\
4(1,7,13,19)\end{array}$ \\
\hline $\begin{array}{l}1956.8-1960.7 \\
1960.8-1962.12\end{array}$ & $\begin{array}{l}\text { As above } \\
\text { South gate } \\
\text { out airort } \\
\text { ( suburb) }\end{array}$ & $\begin{array}{ll}38^{*} & 15^{\circ} \\
38^{\circ} & 17^{\circ}\end{array}$ & $\begin{array}{l}109^{\circ} 25^{\circ} \\
109^{\circ} \\
25\end{array}$ & $\begin{array}{l}1054.0 \\
1057.5\end{array}$ & $\mid \begin{array}{c}\text { Local time } \\
\text { (BeijJing } \\
\text { time })\end{array}$ & $\mid \begin{array}{l}4(1,7,13,19) \\
4(2,8,14,20)\end{array}$ \\
\hline $1963.2-1983$ & & $\left|38^{\circ} 14^{\prime}\right|$ & $109^{\circ} 42^{\prime}$ & 1057.5 & $\mid \begin{array}{c}\text { (Boijมng } \\
\text { timo })\end{array}$ & $4(2,8,14,20)$ \\
\hline
\end{tabular}

C. Number of Observations Used for Calculating the Daily Mean

\begin{tabular}{|c|c|c|c|}
\hline Mean E1mes & $\begin{array}{c}\text { Mean pressure } \\
\text { (Period) }\end{array}$ & $\begin{array}{l}\text { Temperature } \\
\text { (Portod) }\end{array}$ & $\mid \begin{array}{c}\text { Relative humidity } \\
\text { (Period) }\end{array}$ \\
\hline $\begin{array}{l}3(6,14,21) \\
8(3,6,9,12,14, \\
i 8,21,24) \\
4(1,7,13,19) \\
4(2,8,14,20)\end{array}$ & $\begin{array}{l}1954-1960.7 \\
1960.8-1983\end{array}$ & $\begin{array}{r}1954-1960.7 \\
: 960.8-1983\end{array}$ & $\begin{array}{l}1936.11-1948 \\
1951-1953 \\
1952-1953 \\
\\
1954-1960.7 \\
1960.8-1983\end{array}$ \\
\hline
\end{tabular}

D. Remarks : 


\section{B-18}

A. Main Data Sources

$\begin{array}{lr}\text { ¿. } 1916-1950 & (45) \\ \text { 2. } 1951-1970 & (46) \\ \text { 3. } 1971-1980 & (159) \\ \text { 4. } 1981-1983 & (13) \\ \text { 5. } 1971-1980 & (156)\end{array}$

B. Location of Station, Time Standard and Tlmes of Observation

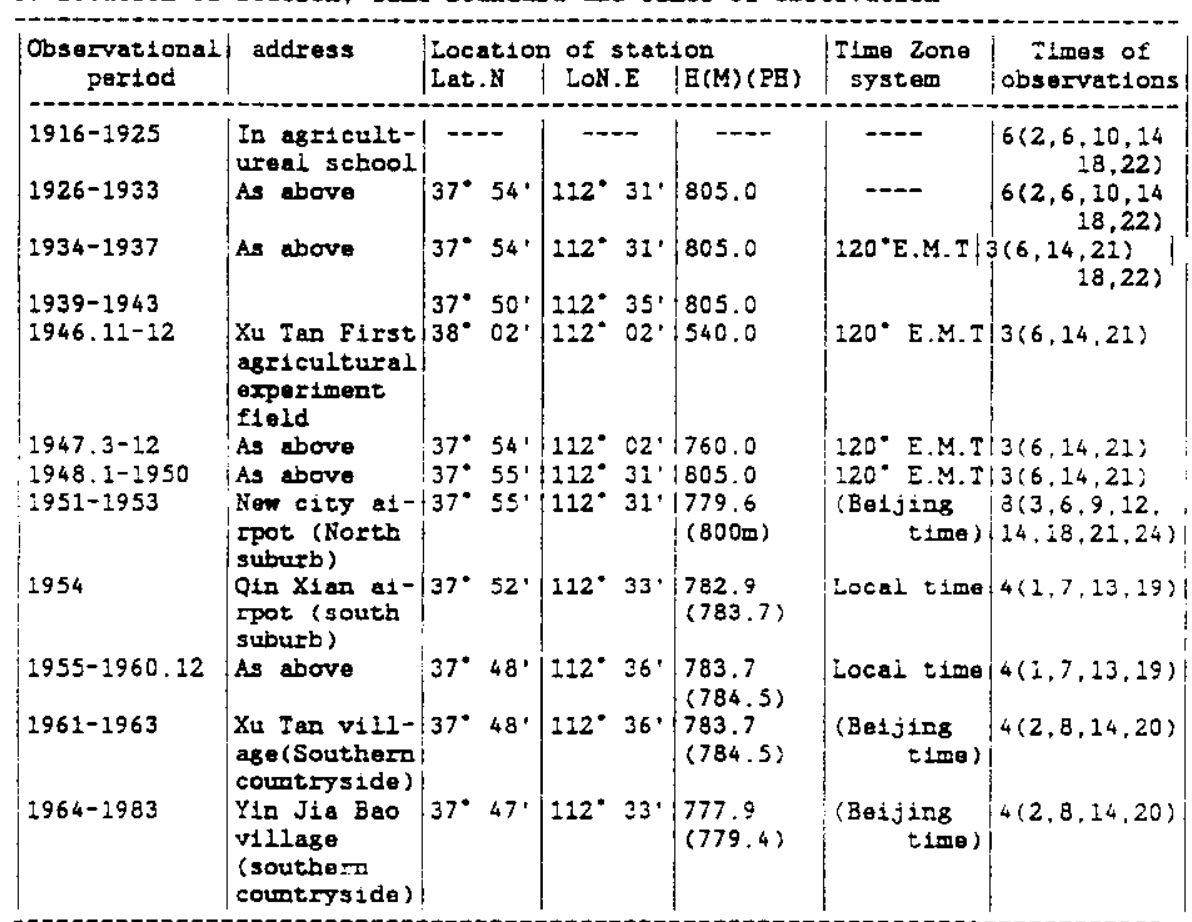

c. Number of Observations Used for Calculating the Daily Mean

\begin{tabular}{|c|c|c|c|}
\hline Mean times & $\begin{array}{c}\text { Mean pressure } \\
\text { (Pertod) }\end{array}$ & $\begin{array}{c}\text { Temperature } \\
\text { (Period) }\end{array}$ & $\begin{array}{l}\text { Relative humidity } \\
\text { (Period) }\end{array}$ \\
\hline $\begin{array}{l}3(6,14,21) \\
6(2,6,10,14,18, \\
22) \\
4(1,7,13,19) \\
4(2,8,14,20)\end{array}$ & $\begin{array}{l}1934-1937.9 \\
1951-1953 \\
1916-1933\end{array}$ & $\begin{array}{l}1934-1937.9 \\
1950-1953 \\
1916-1933 \\
1939-1943 \\
1946.11-12 \\
1947.3-1948 \\
1954-1960.7 \\
1960.8-1983\end{array}$ & $\begin{array}{l}1934-1937.9 \\
1950-1953 \\
1916-1933\end{array}$ \\
\hline
\end{tabular}

D. Remarks :

1. Mean pressure was pressure of tha ice point during the 1916-1935.

2. Date divided time: 24 Beijtng time during 1951-1953

19 local time during $1954-1960.7$

20 Beijing tims during $1960.8-1983$

3. Old name: "Yang Qu " 
No. $17 \quad 54094$ Mu Dan Jiang

A. Main Data Sources
1. $1909-1950$
(61)
2. $1951-1980$
(20)
3. $1981-1983$
(13)
4. 1951-1962 (mean/max/min temperature and cloud amount) $1971-1980$
5. 1963-1970 (mean/max/min temperature and cloud amount) (156)

B. Location of Station. Time Standard and Iimes of Observation

\begin{tabular}{|c|c|c|c|c|c|c|c|}
\hline $\begin{array}{c}\text { Observattonal } \\
\text { period }\end{array}$ & Addrass & $\mid$\begin{tabular}{|l|} 
Locatiog \\
Lat. .
\end{tabular} & $\begin{array}{l}\text { of stat } \\
\text { LON.E }\end{array}$ & $10 \mathrm{E}(\mathrm{M})(\mathrm{PB})$ & $\begin{array}{l}\text { Time } \\
\text { syst }\end{array}$ & $\operatorname{Zon} \theta$ & $\begin{array}{c}\text { Ifmes of } \\
\text { observations }\end{array}$ \\
\hline & & $44^{\circ} 35^{\prime}$ & $129^{\circ} 36^{\circ}$ & & $\begin{array}{l}126^{\circ} \\
\text { E.M }\end{array}$ & ' & , \\
\hline $1937-1943.2$ & $\begin{array}{l}\text { No. } 64 \text { TalP1- } \\
\text { ngAn stroet }\end{array}$ & $44^{\circ} 35^{\prime}$ & $129^{\circ} 36^{\prime}$ & & & M.I & 566, \\
\hline 1949 & As abov & $44^{\circ} 35^{\prime}$ & $129^{\circ} 36^{\prime}$ & & $120^{\circ}$ & M.T & \\
\hline 1949 & As abov & $44^{\circ} 35^{\prime}$ & $129^{\circ} 36^{\prime}$ & .3) & $120^{\circ}$ & E.M.I & $\begin{array}{r}4(6,10,14 \\
18\end{array}$ \\
\hline $1949.4-12$ & As above & $44^{\circ} 35^{\prime}$ & $129^{\circ} 36^{\circ}$ & $\begin{array}{l}5 \\
.3)\end{array}$ & $120^{\circ}$ & E.M.T & $\begin{array}{l}6(2,6,10, \\
14,18,22)\end{array}$ \\
\hline 1950 & As above & $44^{\circ} 35^{\circ}$ & $129^{\circ} 36^{\prime}$ & $\begin{array}{l}240.3 \\
(240.6)\end{array}$ & $120^{\circ}$ & E.M.I & $\begin{array}{l}6(2,6,10, \\
14,18,22)\end{array}$ \\
\hline $1951-1953$ & As above & $44^{\circ} 35^{\prime}$ & $129^{\circ} 36^{\prime}$ & $\begin{array}{l}240.3 \\
(240.6)\end{array}$ & $120^{\circ}$ & E.M.T & 241 \\
\hline $1954-1960.7$ & As above & $44^{\circ} 35^{\prime}$ & $129^{\circ} 36^{\prime}$ & $\begin{array}{l}240.3 \\
(240.6)\end{array}$ & $120^{\circ}$ & E.M.T & $4(1,7,13,19)$ \\
\hline $1960.8-1983$ & As above & $44^{\circ} 34^{\circ}$ & $129^{\circ} 36^{\circ}$ & 241.4 & (Be & $\begin{array}{l}j i n g \\
t \text { ime })\end{array}$ & $4(2,8,14,20)$ \\
\hline
\end{tabular}

c. Number of Observations Used for Calculating the Daily Mean

\begin{tabular}{|c|c|c|c|c|}
\hline Mean times & $\begin{array}{c}\text { Mean pressura } \\
\text { (Poriod) }\end{array}$ & $\begin{array}{l}\text { Temperature } \\
\text { (Period) }\end{array}$ & $\left.\right|_{\text {(Period) }} ^{\text {Relative humidity }}$ & $\begin{array}{l}\text { Wind } \\
\text { (Portod) }\end{array}$ \\
\hline $\begin{array}{c}3(7,: 3,21) \\
6(2,6,20,14, \\
18,22) \\
5(6,10,14, \\
: 8,22) \\
24(1-24) \\
4(1,7,13,19) \\
4(2,8,14,20)\end{array}$ & $\begin{array}{l}1909-1932 \\
1937-1941.4 \\
1949.4-1950 \\
1951-1953 \\
1954-1960.7 \\
1960.8-1983\end{array}$ & $\begin{array}{l}1909-1932 \\
1937-1943.2 \\
2949.4-1950 \\
1951-1953 \\
1954-1960.7 \\
: 960.8-1983\end{array}$ & $\begin{array}{l}1937-1943.2 \\
1949.4-1950 \\
1951-1953 \\
1954-1960.7 \\
1960.8-1983\end{array}$ & $\begin{array}{l}1909-1932 \\
1949.4-1950 \\
1937-1941.4 \\
1951-1953 \\
1954-1960.7 \\
1960.8-1983\end{array}$ \\
\hline
\end{tabular}


A. Main Data Sources
i. $1909-1950$
(47)
2. $1951-1980$
(48)
3. $1981-1983$
(13)

B. Location of Station, Tlone Standard and Tloes of Observation

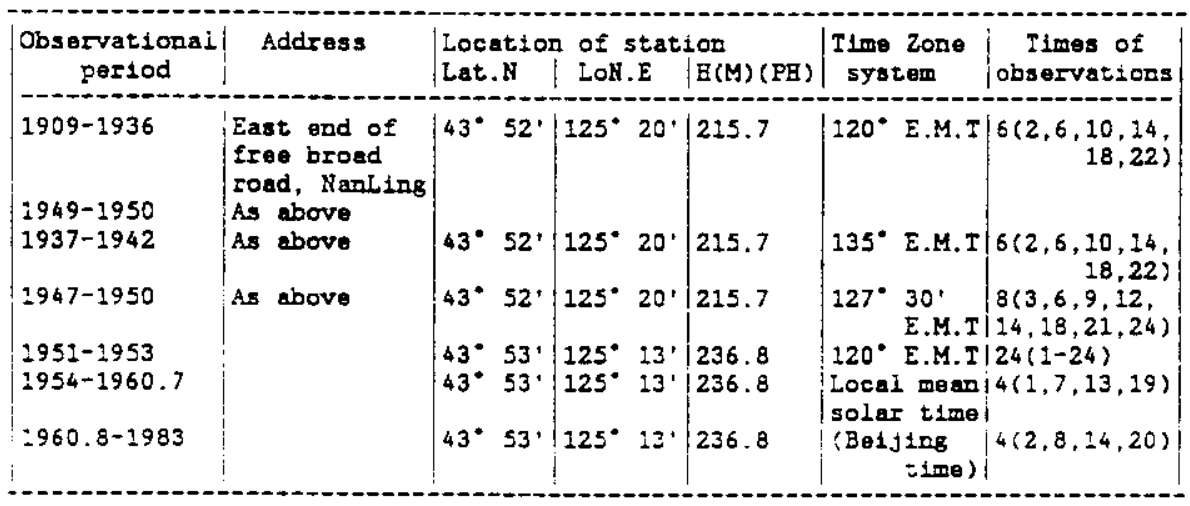

C. Number of Observations Used for Calculating the Daily Mean

\begin{tabular}{|c|c|c|c|}
\hline Mean times & $\begin{array}{l}\text { Mean pressure } \\
\text { (Period) }\end{array}$ & $\begin{array}{c}\text { Temperature } \\
\text { (Period) }\end{array}$ & $\begin{array}{l}\text { Relative humidity } \\
\text { (Pertod) }\end{array}$ \\
\hline $\begin{array}{r}3(6,14,21) \\
6(2,6,10,14, \\
18,22) \\
8(3,6,9,12, \\
14,18,21,24) \\
24(1-24) \\
4(1,7,13,19) \\
4(2,8,14,20)\end{array}$ & $\begin{array}{l}1929.5-1936 \\
1909-1929.4 \\
1937-1941.4 \\
1949-1950\end{array}$ & $\begin{array}{l}1929.5-1936 \\
1909-1929.4 \\
1937-1942.4 \\
1949-1950 \\
1947-1948 \\
\\
1951-1953 \\
1954-1960.7 \\
1960.8-1983\end{array}$ & $\begin{array}{l}1929.5-1936 \\
1909-1929.4 \\
1937-1942.4 \\
1949-1950 \\
1947-1948 \\
1951-1953 \\
1954-1960.7 \\
1960.8-1983\end{array}$ \\
\hline
\end{tabular}

2. Remarks : 
A. Main Data Sources

$\begin{array}{ll}\text { 1. } 1905-1950 & (49) \\ \text { 2. } 1951-1960 & (50) \\ \text { 3. } 1961-1970 & (51) \\ \text { 4. } 1971-1980 & (51) \\ \text { 5. } 1981-1983 & (13)\end{array}$

B. Location of Station, Time Standard and Times of Observation

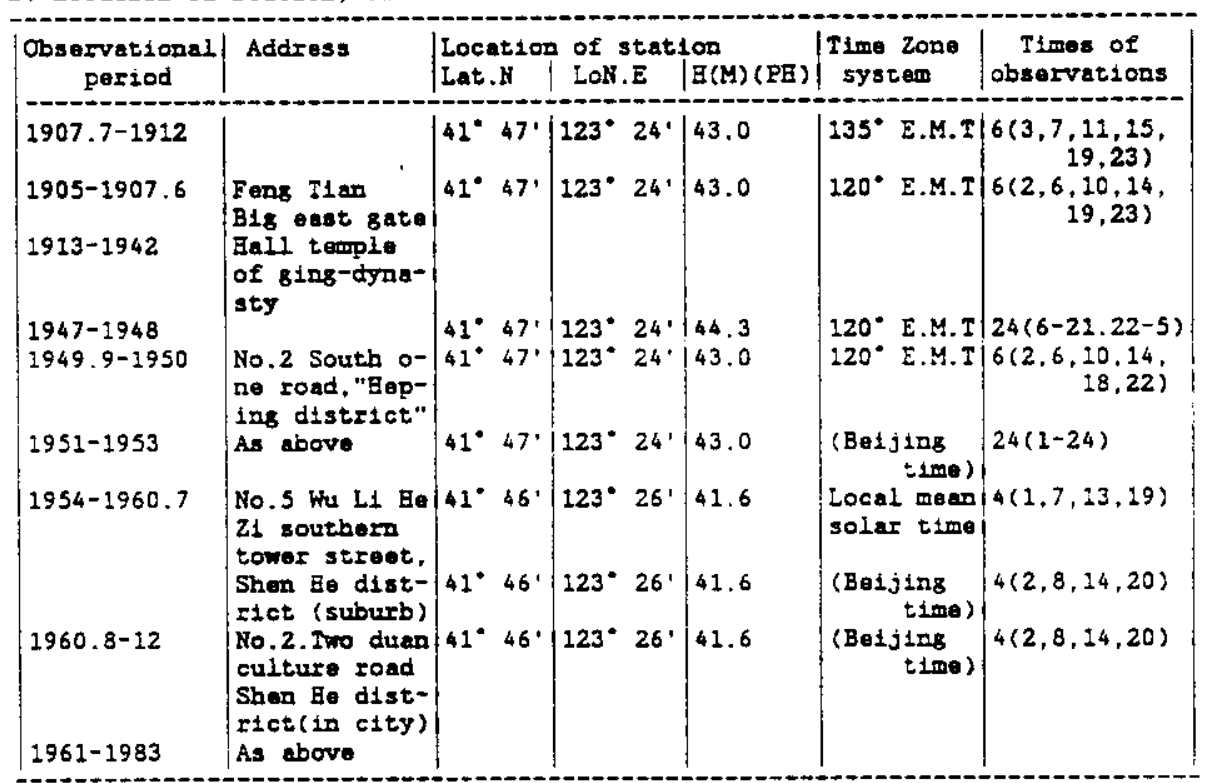

C. Number of Observations Used for Calculating the Dally Mean

\begin{tabular}{|c|c|c|c|c|}
\hline Mean times & $\mid \begin{array}{c}\text { Mean pressure } \\
\text { (Pertod) }\end{array}$ & $\begin{array}{l}\text { Temperature } \\
\text { (Pertod) }\end{array}$ & $\mid \begin{array}{c}\text { Relative humidity } \\
\text { (Reriod) }\end{array}$ & $\begin{array}{l}\text { wind } \\
\text { (Derlod) }\end{array}$ \\
\hline $3(6,14,22)$ & 1950 & $\begin{array}{l}1929.5-1936.7 \\
1905-1907.6\end{array}$ & 1950 & \\
\hline $\begin{array}{r}6(2,6,10,14 \\
: 8,22)\end{array}$ & $\begin{array}{l}1905-1907.6 \\
1913-1942,1949\end{array}$ & $\begin{array}{l}1913-1929.4 \\
1936.8-1942 \\
1949-1950\end{array}$ & $\begin{array}{l}1905-1907.6 \\
1913-1942.1949\end{array}$ & \\
\hline $\begin{array}{r}6(3,7,11,15 \\
19,23) \\
24(1-24) \\
4(1,7,13,19) \\
4(2,8,14,20)\end{array}$ & $\begin{array}{l}1907.7-1912 \\
1947-1948 \\
1951-1953 \\
1954-1960.7 \\
1960.8-1983\end{array}$ & $\begin{array}{l}1907-1912 \\
1947-1948 \\
1951-1953 \\
1954-1960.7 \\
1960.8-1983\end{array}$ & $\begin{array}{l}1907.7-1912 \\
1947-1948 \\
1951-1953 \\
1954-1960.7 \\
1960.8-1983\end{array}$ & $\begin{array}{l}1951-1953 \\
1954-1960.7 \\
1960.8-1983\end{array}$ \\
\hline
\end{tabular}

D. Remarixs:

There were more small wind speed and higher temperature during the 1951-1953 years, because this station was in city. The records has a better representativeness after 1953. 
A. Main Data Sources
i. $1841-1980$
2. $1981-1983$
(52)
(13)

E. Location of Station, Time Standard and Times of Observation

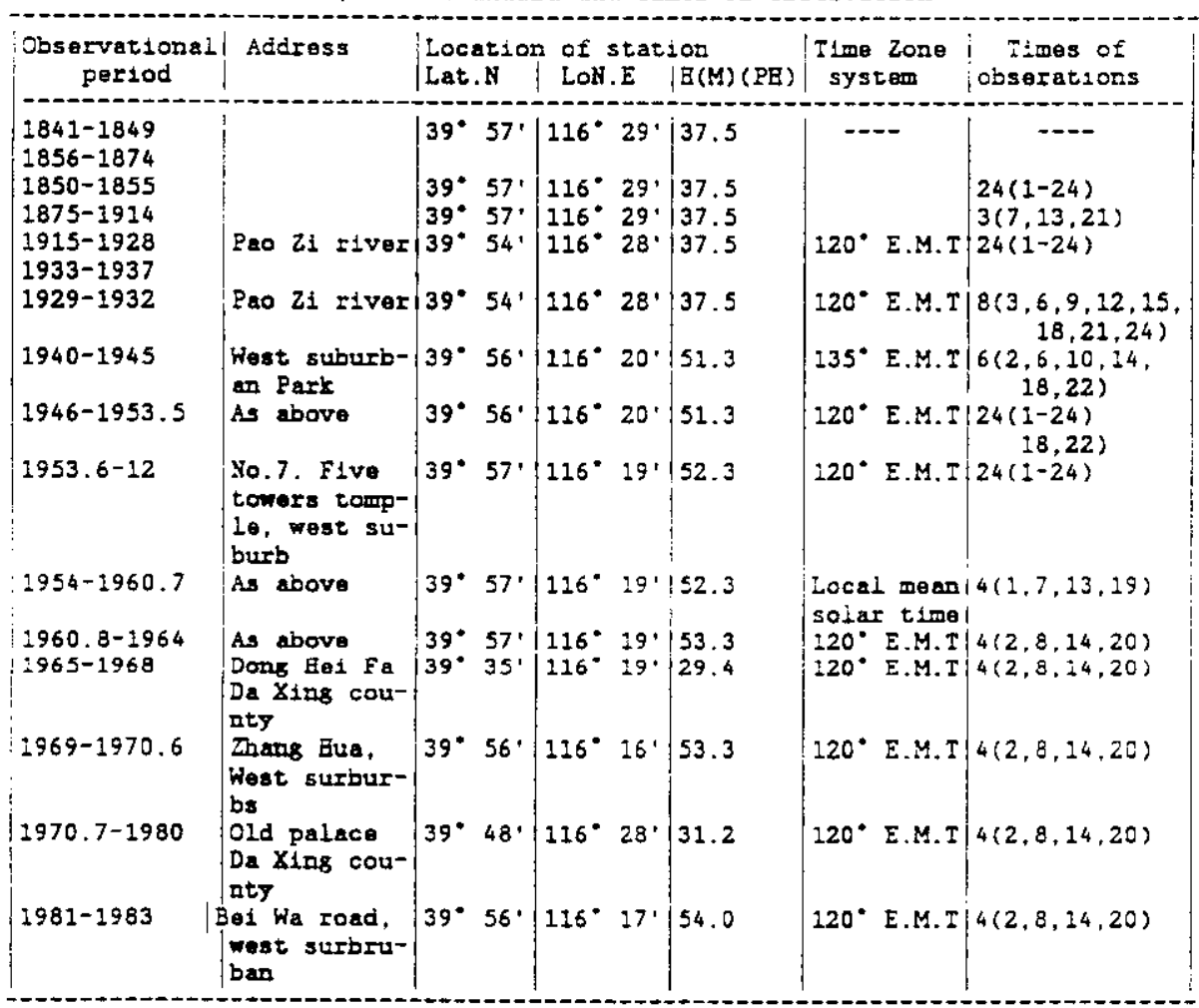

c. Number of Observations Used for Calculating the Daily Mean

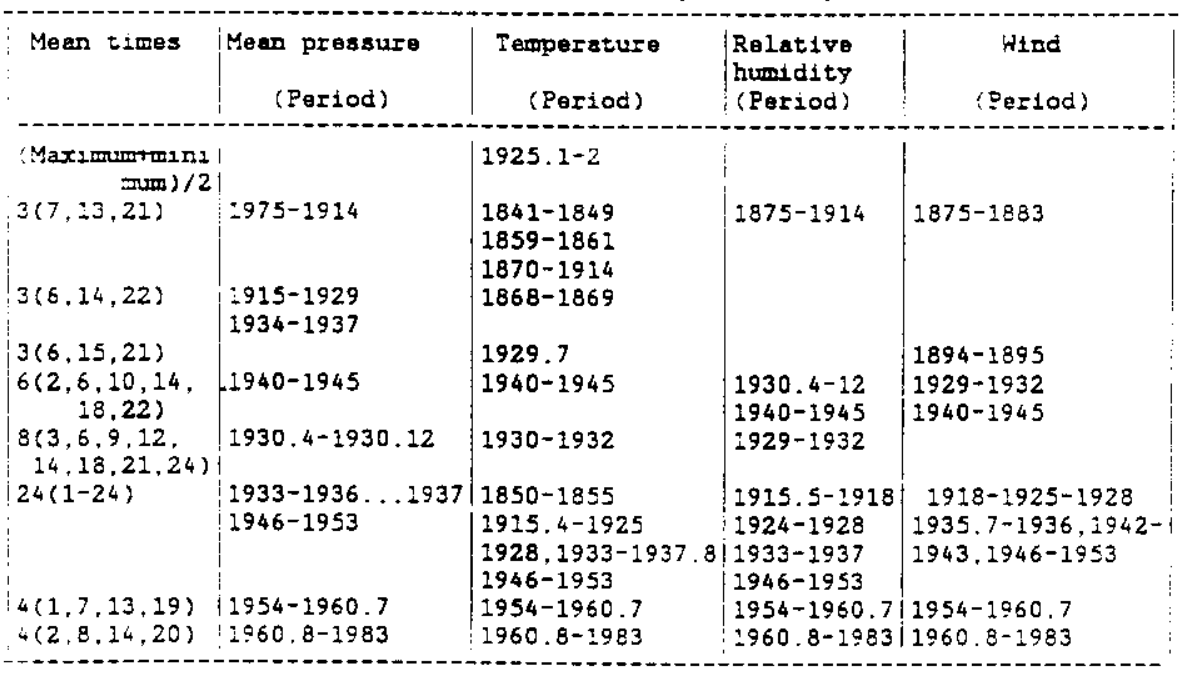




\section{B-23}

No. 2054511 Beij12g (cont.)

D. Remarks:

Date divided time: not clear during 1875-1895

$24120^{\circ}$ E mean time during 1915-1932

$24120^{\circ} \mathrm{E}$ mean time during $1934-1937$

$24120^{\circ} \mathrm{E}$ mean time durins 1946-1953

$21120^{\circ} \mathrm{E}$ mean time during 1933

22 135"E mean time durt28 1940-1945

19 local mean solar time (L.M.S.T.) during 1954-1960

$20120^{\circ} \mathrm{E}$ mean solar time since 1960.8 


\section{B-24}

io. 2: $54527 \quad 2$ an $\mathrm{jin}$

A. Main Data Sources

$\begin{array}{lc}\text { i. } 1891-1904 & (1) \\ \text { 2. } 1891-1906.6 & (3) \\ \text { 3. } 1904-1950 & (53) \\ \text { 4. } 1951-1980 & (54) \\ \text { 5. } 1981-1983 & (13) \\ \text { 5. } 1951-1954 \text { (Fressure. temperature, humidity, and winds) (12) } \\ \text { 7. } 1928-1936 \text { (cloud amount) }\end{array}$

B. Location of Station, Time Standard and Times of Observation

\begin{tabular}{|c|c|c|c|c|c|c|}
\hline $\begin{array}{c}\text { Cbservational } \\
\text { period }\end{array}$ & Address & $\begin{array}{l}\text { Locatiog } \\
\text { Lat.N }\end{array}$ & $\left|\begin{array}{l}\text { of statt } \\
\text { LoN.E }\end{array}\right|$ & $\mid \begin{array}{l}\mathrm{B} \\
\mathrm{B}(\mathrm{M})(\mathrm{PB})\end{array}$ & \begin{tabular}{|} 
T1me Zone \\
system
\end{tabular} & $\begin{array}{c}\text { Times of } \\
\text { observations }\end{array}$ \\
\hline i891-1904 & $\begin{array}{l}\text { Beitainnic } \\
\text { concossion }\end{array}$ & $39^{\circ} 07^{\prime}$ & $\left|117^{\circ} 12^{\prime}\right|$ & & & $3(9,12,16)$ \\
\hline $\begin{array}{c}-1906 \\
1904-1927 \\
1928-1934,1936\end{array}$ & & 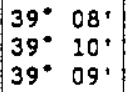 & $\left|\begin{array}{ll}117^{\circ} & 11^{\prime} \\
117^{\circ} & 10^{\prime} \\
117^{\circ} & 09^{\prime}\end{array}\right|$ & $\begin{array}{r}19.0 \\
5.0 \\
4.5\end{array}$ & & \\
\hline $1937.1-7$ & $\begin{array}{l}\text { Five rosds } \\
\text { of italian } \\
\text { concession }\end{array}$ & $39^{\circ} 08^{\prime}$ & $117^{\circ} 12$ & 19.0 & $220^{\circ}$ E.M.I & $3(6,14,22)$ \\
\hline $\begin{array}{l}1938-1945 \\
1946-1949\end{array}$ & $\begin{array}{l}\text { As above } \\
\text { No. } 17 \text {. Nan } \\
\text { Jing road ft } \\
\text { sst district }\end{array}$ & $\left|\begin{array}{ll}39^{\circ} & 08^{\prime} \\
39^{\circ} & 09^{\prime}\end{array}\right|$ & $\begin{array}{l}117^{\circ}: 2^{\prime} \\
116^{\circ} \\
\end{array}$ & $\begin{array}{r}19.0 \\
4.6\end{array}$ & $\begin{array}{l}: 20^{\circ} \text { E.M.T } \\
: 20^{\circ} \text { E.M.I }\end{array}$ & $\begin{array}{l}24(1-24) \\
8(3,6,9,12, \\
14,18,21,24)\end{array}$ \\
\hline$\therefore 950-$ & $\begin{array}{l}\text { Thang Giei } \\
\text { village }\end{array}$ & $39^{\circ} 09^{\prime}$ & $117^{\circ} 23^{\circ}$ & 2.9 & $220^{\circ}$ E.M.TI & $\begin{array}{l}8: 3,6,9,12 \\
24,18,22,24,\end{array}$ \\
\hline $29 \leq 1-1953$ & $\begin{array}{l}\text { No. } 22 \text {. Froo } \\
\text { road, two } \\
\text { district, }\end{array}$ & $139^{\circ} 08^{\circ}$ & $117^{\circ} 11$ & 16.0 & $220^{\circ} \mathrm{E.M.T}$ & $24(1-24)$ \\
\hline 2954 & As above & $39^{\circ} 08^{\prime}$ & $117^{\circ} 12$ & 16.0 & $\begin{array}{r}117^{\circ} \text { Socal } \\
\text { Mean solar } \\
\text { time }\end{array}$ & $4(1,7,13,19)$ \\
\hline $1955-1960.7$ & $\begin{array}{l}\text { Meteo-stati- } \\
\text { on road. }\end{array}$ & $39^{\circ} 06^{\prime}$ & $117^{\circ} 10^{\prime}$ & 3.3 & $\begin{array}{r}127 \text { inLocal } \\
\text { Mean solar } \\
\text { ttose }\end{array}$ & $(1,7,13,19)$ \\
\hline $1960.8-1983$ & is above & $39^{\circ} 06^{\prime}$ & $117^{\circ}: 0^{\circ}$ & 3.3 & $\begin{array}{c}(B e j j i n g \\
t i m \theta)\end{array}$ & $4(2,8,14,20)$ \\
\hline
\end{tabular}

c. Number of Observations Used for Calculating the Daily Mean

\begin{tabular}{|c|c|c|c|c|}
\hline Mean tises & $\begin{array}{l}\text { Mean pressure } \\
\text { (Period) }\end{array}$ & $\begin{array}{c}\text { Temperature } \\
\text { (Feriod) }\end{array}$ & $\begin{array}{l}\text { Rolative humadity } \\
\text { (Period) }\end{array}$ & $\begin{array}{c}\text { ind } \\
\text { (Period) }\end{array}$ \\
\hline $\begin{array}{l}3(9,22,16) \\
3(6,: 4,22) \\
3(6,24,21)\end{array}$ & $\begin{array}{l}: 904-1934,1939 \\
: 946-1950\end{array}$ & $\begin{array}{l}1891-1904 \\
1904-1934,: 936\end{array}$ & $12904-1934.1936$ & \\
\hline $\begin{array}{l}3(3.6,9,22) \\
: 4,-8.2 \div, 24)\end{array}$ & & $1946-1950$ & & \\
\hline $24(i-24)$ & $\begin{array}{r}: 937-1942 \\
1944-1945 \\
: 1951-1953\end{array}$ & $\begin{array}{l}1937-1942 \\
1941-1945 \\
1951-1953\end{array}$ & $\begin{array}{l}1937-1942 \\
1944-1945 \\
1951-1953\end{array}$ & $: 951-2953$ \\
\hline $\begin{array}{l}4(1.7 .13 .19) \\
4(2.8 .14 .20)\end{array}$ & $\begin{array}{l}1954-1960.7 \\
1950.8-1983\end{array}$ & $\begin{array}{l}1954-1960.7 \\
: 960.8-1983\end{array}$ & $\begin{array}{l}1954-1960.7 \\
1960.8-1983\end{array}$ & $\begin{array}{l}1954-1960.7 \\
1960.8-1983\end{array}$ \\
\hline
\end{tabular}

2. Eemarks : 
A. Main Data Sources
1. $1913-1935$
2. $1914-1948$
3. $1927-1950$
4. $1927-1950$
5. $1951-1960$
6. 1961-1970 (precipttation, cloud, temperature, winds, 1971-1980 humidity, pressure, sunshine, and weather days data of $\mathrm{Ee}$ Bel province.)
7. $1981-1983$
8. 1929-1936 (pressure, cloud, whd speed.
and dominant winds)
(1)
(3)
(4)
$(5)$
(55)
(12)

(15)

B. Location of Station, Tloe Standard and Ilose of Observation

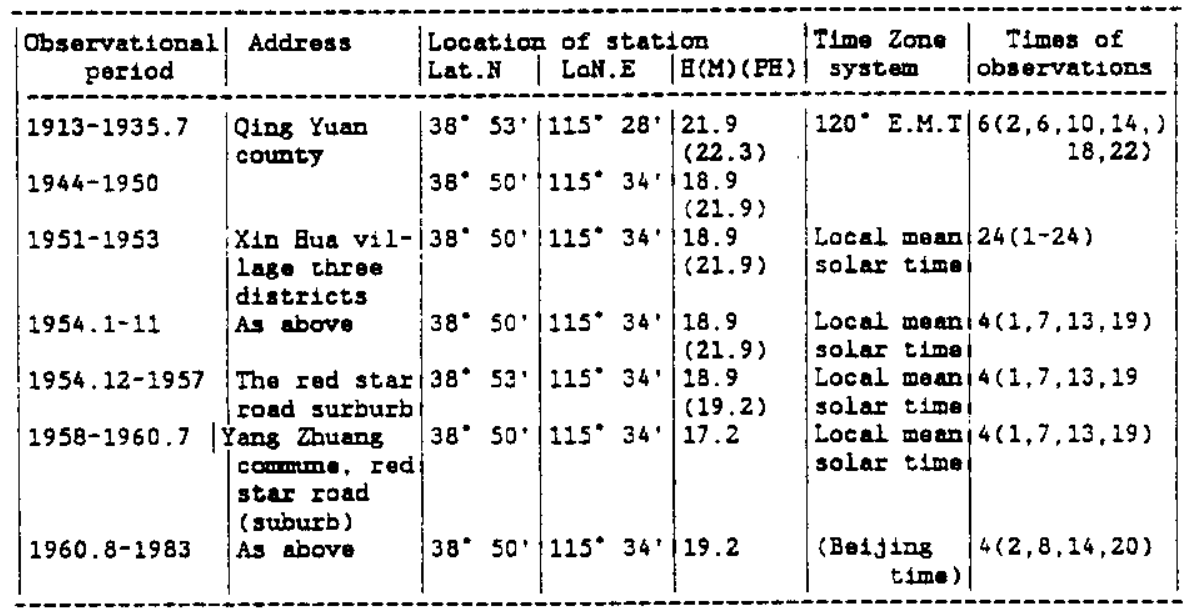

C. Number of Observations Used for Calculating the Dally Mean

\begin{tabular}{|c|c|c|c|}
\hline Mean times & $\begin{array}{c}\text { Mean pressure } \\
\text { (Period) }\end{array}$ & $\begin{array}{c}\text { Temperature } \\
\text { (Period) }\end{array}$ & $\mid \begin{array}{c}\text { Relative humlity } \\
\text { (Period) }\end{array}$ \\
\hline $\begin{array}{c}6(2,6,10,14, \\
18,22) \\
3(6,14,22) \\
6(1,5,9,13 \\
\vdots 7,21) \\
8(3,6,9,12 \\
14,18,21,24) \\
3(7,14,21) \\
3(6,14,21) \\
4(1,7,13,19) \\
4(2,8,14,20)\end{array}$ & $\begin{array}{l}1951-1953 \\
1954-1960.7 \\
1960.8-1983\end{array}$ & $\begin{array}{l}1951-1953 \\
1954-1960.7 \\
1960.8-1983\end{array}$ & $\begin{array}{l}1927-1936.4 \\
1944-1945 \\
1946-1948.10 \\
1949.9-1952.6 \\
1952.7-1953 \\
1954-1960.7 \\
1960.8-1983\end{array}$ \\
\hline
\end{tabular}

D. Remarks : 
A. Main Data Sources

$\begin{array}{ll}\text { 2. } 1904-1950 & (57) \\ \text { 2. } 1951-1960 & (58) \\ \text { 3. } 1961-1970 & (59) \\ \text { 4. } 1971-1980 & (60) \\ \text { S. } 1981-1983 & (13) \\ \text { 6. } 1928-1936 \text { (cloud amourst) } & (14)\end{array}$

3. Location of Station, TIme Standard and Times of Observation

\begin{tabular}{|c|c|c|c|c|c|c|}
\hline $\begin{array}{c}\text { Observational } \\
\text { period }\end{array}$ & Address & $\mid \begin{array}{l}\text { Location } \\
\text { Lat.N }\end{array}$ & $\begin{array}{l}\text { n of stat: } \\
\text { LoN.E. }\end{array}$ & $|\mathrm{E}(\mathrm{M})(\mathrm{PE})|$ & $\begin{array}{c}\text { Time Zone } \\
\text { system }\end{array}$ & $\mid \begin{array}{c}\text { Times of } \\
\text { observations }\end{array}$ \\
\hline $1904-1906$ & & $\left|38^{\circ} 56^{\circ}\right|$ & $121^{\circ} 36^{\circ}$ & 5.4 & $120^{\circ}$ E.M.T & $\left.\mid \begin{array}{r}6(2,6,10,14 \\
18,22\end{array}\right)$ \\
\hline 1907-1917 & S1 Er Gou & $38^{\circ} 56^{\circ}$ & $221^{\circ} 36^{\prime}$ & 12.4 & $120^{\circ}$ E.M.T & $\left|\begin{array}{r}6(2,6,10,14 \\
18,22\end{array}\right|$ \\
\hline $1918-1940$ & & $38^{\circ} 54^{\circ}$ & $121^{\circ} 38^{\circ}$ & 95.6 & $120^{\circ}$ E.M.I & $\begin{array}{r}6(2,6,10,14 \\
18,22)\end{array}$ \\
\hline 1950 & $\begin{array}{l}\text { XingGong str- } \\
\text { oot sbake Kou } \\
\text { district }\end{array}$ & $\left.38^{\circ} 54^{\prime}\right\}$ & $121^{\circ} 38^{\circ}$ & 33.8 & $(B \in 1 j 1 n g$ & $\begin{array}{r}6(2,6,10,24 \\
18,22)\end{array}$ \\
\hline 1951 & $\begin{array}{l}\text { No. } 886 \text { Xing } \\
\text { Gons street } \\
\text { Sha He Kou } \\
\text { district }\end{array}$ & $38^{\circ} 54^{\circ}$ & $121^{\circ} 38^{\prime}$ & 31.8 & (Beijing & $24(1-24)$ \\
\hline $1952-1953$ & $\begin{array}{l}\text { the Chang iron } \\
\text { Stan alley } \\
\text { Zhong Shan } \\
\text { district }\end{array}$ & $38^{\circ} 54^{\prime}$ & $121^{\circ} 38^{\prime}$ & 195.6 & $\left(\begin{array}{c}(B 01 j 108 \\
t \pm 08\end{array}\right.$ & $24(1-24)$ \\
\hline $1954-1956$ & As above & $38^{\circ} 54^{\circ}$ & $121^{\circ} 38^{\circ} \mid$ & 95.6 & $\begin{array}{l}\text { socal mean } \\
\text { solar time }\end{array}$ & $4(1,7,23,19)$ \\
\hline $1957-1960.7$ & $\begin{array}{l}\text { South meanta- } \\
\text { in sea-front } \\
\text { Jin county }\end{array}$ & $39^{\circ} 01^{\prime}$ & $121^{\circ} 43^{\prime}$ & 62.4 & $\begin{array}{l}\text { Local mean! } \\
\text { solar timo }\end{array}$ & $4(1,7,13,29)$ \\
\hline $1960.8-1967$ & As above & $39^{\circ} 01^{\prime}$ & $121^{\circ} 43^{\prime}$ & 62.4 & $\begin{array}{c}(\text { Beijing } \\
\text { time })\end{array}$ & $4(2,8,14,20)$ \\
\hline $1968.1-6$ & As above & $39^{\circ} 01$ & $121^{\circ} 43^{\circ}$ & 62.4 & $\begin{array}{c}(8) 1 j 1 n g \\
t \pm \operatorname{ma})\end{array}$ & $3(8,14,20)$ \\
\hline $1968.7-1969.3$ & As above & $39^{\circ} 01^{\circ}$ & $121^{\circ} 43^{\prime}$ & 62.4 & $\begin{array}{c}(B e i j \operatorname{lng} \\
\operatorname{tIm\theta })\end{array}$ & $4(2,8,14,20)$ \\
\hline$: 969.4-1970$ & $\begin{array}{l}\text { KurMing stra- } \\
\text { et iron moum- } \\
\text { tain range, } \\
\text { Zhong Shan } \\
\text { district }\end{array}$ & $3^{38^{\circ} 54^{\prime}}$ & $\left|322^{\circ} 33^{\prime}\right|$ & 95.6 & $\begin{array}{c}(\text { Seljing } \\
\text { =ime })\end{array}$ & $4(2,8,24,20)$ \\
\hline$-971-1575.9$ & As above & $38^{\circ} 54^{\circ}$ & $127^{\circ} 38^{\circ}$ & 193.5 & $\begin{array}{r}\text { (Eeijlng } \\
\text { :1me) }\end{array}$ & $|4(2,8,14,20)|$ \\
\hline$: 975.10-1983$ & I As above & $38^{\circ} 54^{\prime}$ & $121^{\circ} \Xi \Omega^{\circ}$ & 92.8 & $\begin{array}{c}\text { Beijing } \\
\text { =ime }\end{array}$ & $4(2.8,-4,20) 1$ \\
\hline
\end{tabular}

C. Number of Observations Used for Calculating the Dally Mean

\begin{tabular}{|c|c|c|c|c|}
\hline Mean times & $\begin{array}{c}\text { Mean pressure } \\
\text { (Period) }\end{array}$ & $\begin{array}{l}\text { Temperature } \\
\text { (Eeriod) }\end{array}$ & $\begin{array}{l}\text { Relative numidity } \\
\text { (Pertod) }\end{array}$ & $\begin{array}{l}\text { rind } \\
\text { (Period) }\end{array}$ \\
\hline $\begin{array}{l}3(6,14,22) \\
6(2,6,10,14, \\
\quad 3,22) \\
24(1-24) \\
4(1,7,13,19) \\
4(2,8,14,20)\end{array}$ & $\begin{array}{l}1934-1935 \\
1905-1933 \\
1936-1940,1950 \\
1951-1953 \\
1954-1960.7 \\
1960.8-1983\end{array}$ & $\begin{array}{l}1934-1935 \\
1905-1933 \\
1936-1940,1950 \\
1951-1953 \\
1954-1960.7 \\
1960.8-1983\end{array}$ & $\begin{array}{l}1934-1935 \\
1905-1933 \\
1936-1940,1950 \\
1951-1953 \\
: 954-1960.7 \\
1960.8-1983\end{array}$ & $\begin{array}{l}1951-1953 \\
1954-1960.7 \\
1960.8-1983\end{array}$ \\
\hline
\end{tabular}

2. Remariks : 
A. Mair Data Sourcas

$\begin{array}{rr}\text { 1. } 1886-1938 & (3) \\ \text { 2. } 1924-1943 & (2) \\ \text { 3. } 1907-1950 & (4) \\ \text { 4. } 1909-1936 \text { (pressure) } & (5) \\ \text { 5. } 1905-1936 \text { (proser } & (15) \\ 1905-1923 \text { (temperture) } & \\ 1928-1936 \text { (wind speed, cloud amount) } & \\ 1928-1933 & (62) \\ \text { 6. } 1937-1943 & (63) \\ \text { 7. } 1951-1960 & (64) \\ \text { 8. } 1971-1980 & (157) \\ \text { 9. } 1961-1970 & (13)\end{array}$

B. Location of Station, Time Standard and Times of Observation

\begin{tabular}{|c|c|c|c|c|c|c|}
\hline $\begin{array}{c}\text { Observational } \\
\text { period }\end{array}$ & Address & $\begin{array}{l}\text { Location } \\
\text { Lat. }\end{array}$ & $\mid \begin{array}{l}\text { of stat } \\
\text { LoN.E }\end{array}$ & $\begin{array}{l}\text { ton } \\
\mid \mathrm{E}(\mathrm{M})(\mathrm{PB})\end{array}$ & $\begin{array}{l}\text { T1me } \operatorname{Zon} \theta \\
\text { systen }\end{array}$ & $\begin{array}{c}\text { Times of } \\
\text { observations }\end{array}$ \\
\hline $1886-1942$ & $\begin{array}{l}\text { Caefoo } \\
\text { station }\end{array}$ & $37^{*} 33^{\prime}$ & $\left.\mid 121^{\circ} 22^{\prime}\right\}$ & 3.0 & $120^{\circ}$ E.M.I & \\
\hline $\begin{array}{c}-1950 \\
1951.1-1952\end{array}$ & $\begin{array}{l}\text { No: } 20 \text { Eroad } \\
\text { road in city }\end{array}$ & $\left|\begin{array}{ll}37^{*} & 32 \\
37^{\circ} & 36^{\prime}\end{array}\right|$ & $121^{\circ} 23 !$ & $\begin{array}{l}\mid \begin{array}{l}45.6 \\
12.1 \\
(13.5)\end{array}\end{array}$ & $\begin{array}{c}(B) 1 j \operatorname{sing} \\
t \operatorname{ln\theta })\end{array}$ & $24(1-24)$ \\
\hline 1953- & $\begin{array}{l}\text { "Sea-front" } \\
\text { tho grape } \\
\text { mountain }\end{array}$ & $37^{\circ} 32^{\prime}$ & $127^{\circ} 24^{\prime}$ & $\begin{array}{l}46.7 \\
(47.2)\end{array}$ & $\begin{array}{c}(B \otimes i j \pm n g \\
t \pm m e\end{array}$ & $24(1-24)$ \\
\hline $1954-1957.5$ & $\begin{array}{l}\text { Sea-front } \\
\text { the grape } \\
\text { station }\end{array}$ & $37^{\circ} 32$. & $12 I^{\circ} 24^{\prime} \mid$ & 46.7 & Local time & $4(1,7,13,19)$ \\
\hline $1957.6-11$ & As above & $37^{*} 32^{\prime}$ & $121^{\circ} 24^{\prime}$ & $\mid \begin{array}{l}46.7 \\
(37.5)\end{array}$ & Local time & $4(1,7,13,19)$ \\
\hline $1957.22-1960.6$ & As above & $37^{*} 32^{\prime}$ & $121^{\circ} 24^{\circ}$ & $\begin{array}{l}46.7 \\
(40.9)\end{array}$ & Local time & $4(1,7,13,19)\}$ \\
\hline $1961.7-1964.8$ & As above & $37^{\circ} 32^{\prime}$ & $121^{\circ} 24^{\prime}$ & $\mid \begin{array}{l}46.7 \\
(44.7)\end{array}$ & $\begin{array}{c}(B e i j i n g \\
t \operatorname{lm} \theta)\end{array}$ & $4(2,8,14,20)$ \\
\hline & As above & $37^{\circ} 32^{\prime}$ & $121^{\circ} 24^{\circ}$ & $\begin{array}{l}46.7 \\
(40.9)\end{array}$ & $\begin{array}{c}\text { (Be1jing } \\
\text { time })\end{array}$ & $4(2,8,14,20)$ \\
\hline $1976.12-1983$ & As above & $37^{\circ} 322^{\prime}$ & $121^{\circ} 24^{\prime}$ & $\begin{array}{l}46.7 \\
(47.8)\end{array}$ & $\begin{array}{c}\text { (Betjing } \\
\text { fine })\end{array}$ & $4(2,8,14,20)$ \\
\hline
\end{tabular}

C. Number of Observations Used for Calculating the Daily Mean

\begin{tabular}{|c|c|c|c|c|}
\hline Mean times & $\begin{array}{c}\text { Mean pressure } \\
\text { (Poriod) }\end{array}$ & $\begin{array}{c}\text { Temperature } \\
\text { (Period) }\end{array}$ & $\begin{array}{l}\text { Relative humidity } \\
\text { (Period) }\end{array}$ & $\begin{array}{l}\text { Wind } \\
\text { (Period) }\end{array}$ \\
\hline $\begin{array}{c}(\operatorname{Mar} \operatorname{Min}) 1 / 2 \\
8(3,6,9,12, \\
15,18,21,24) \\
3(6,14,21) \\
3(6,14,22)\end{array}$ & & $\begin{array}{l}1924-1928 \\
1929-1933 \\
1934-1935\end{array}$ & $\begin{array}{l}1907-1936 \\
1939-1940\end{array}$ & \\
\hline $\begin{array}{l}24(1-24) \\
4(1,7,13,19) \\
4(2,8,14,20)\end{array}$ & $\begin{array}{l}1951.1-1953 \\
1954-1960.6 \\
1960.8-1983\end{array}$ & $\begin{array}{l}1951.1-1953 \\
1954-1960.6 \\
1960.8-1983\end{array}$ & $\begin{array}{l}1951.1-1953 \\
1954-1960.6 \\
1960.8-1983\end{array}$ & $\begin{array}{l}1951.1-1953 \\
1954-1960.6 \\
1960.7-\$ 983\end{array}$ \\
\hline
\end{tabular}

\section{ว. Remariks :}

$\therefore$ Relativa humidity data were not corrected by the pressure

2. Old name: "shefoo" 


\section{B-28}

Yo. $25 \quad 54823 \quad$ IS Xan

A. Main Data Sources

\begin{tabular}{|c|c|}
\hline $\begin{array}{l}1916-1950 \\
1951-1980 \\
1981-1983 \\
1932-1936\end{array}$ & $\begin{array}{l}(65) \\
(66) \\
(13) \\
(15)\end{array}$ \\
\hline
\end{tabular}

S. Location of Station, Time Standard and Times of Observations

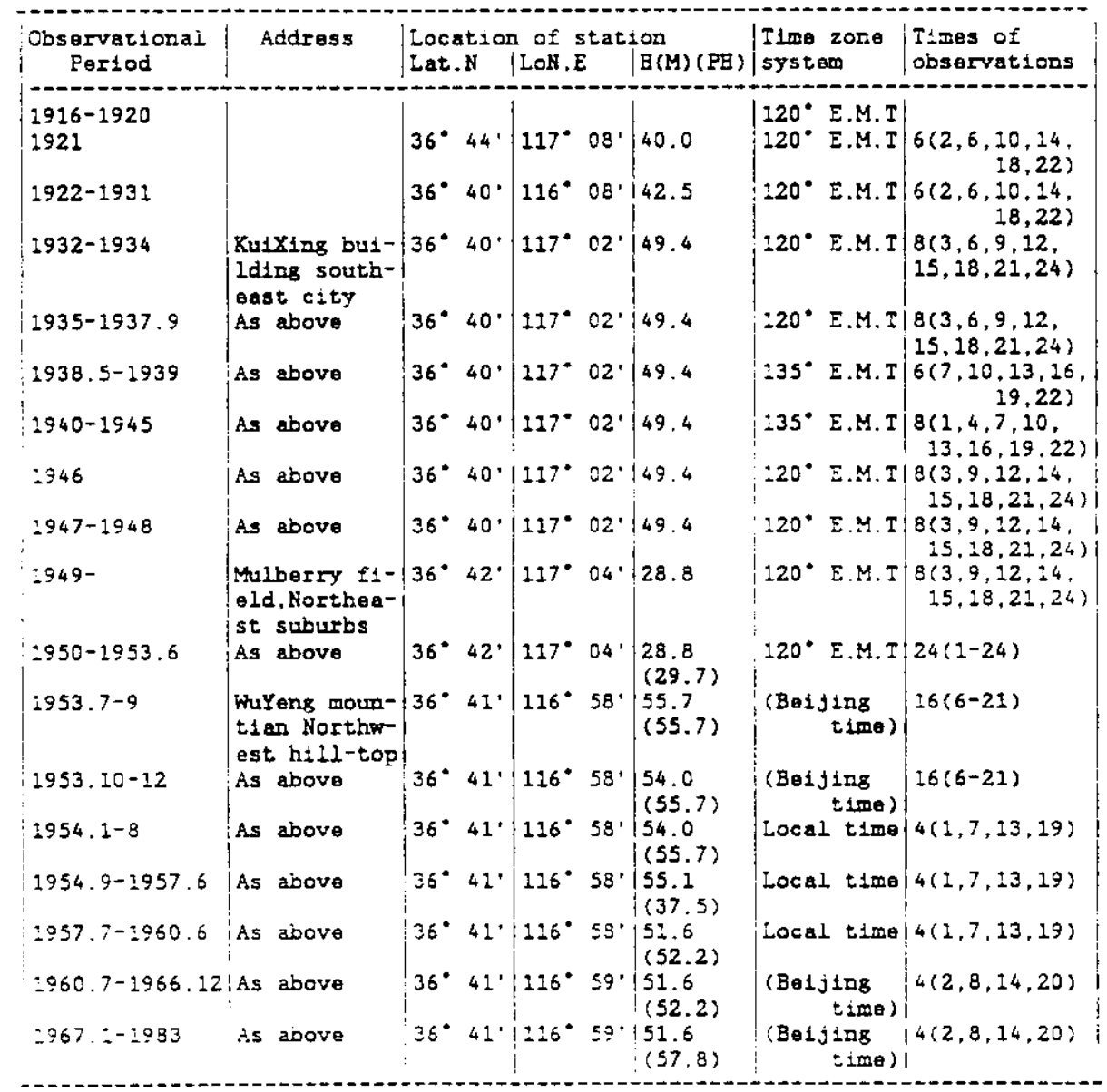


No. 2554823 Ii Nan (cont.)

C. Number of Observations Used for Calculating the Daily Mean

\begin{tabular}{|c|c|c|c|c|}
\hline Mean times & $\left|\begin{array}{c}\text { Mean pressure } \\
\text { (period) }\end{array}\right|$ & $\begin{array}{c}\text { Teruperature } \\
\text { (period) }\end{array}$ & \begin{tabular}{|} 
Rolative bumidity \\
(period)
\end{tabular} & $\begin{array}{l}\text { Wind } \\
\text { (period) }\end{array}$ \\
\hline & $\mid \begin{array}{l}1919-1920 \\
1938.5-1939\end{array}$ & $1919-1920$ & $1919-1920$ & \\
\hline $\begin{array}{l}3(6,14,21) \\
6(2,6,10,14, \\
18,22)\end{array}$ & $1921-1931$ & $\begin{array}{l}1936-1937.9 \\
1921-1931\end{array}$ & 1921-1931 & \\
\hline $\begin{array}{c}6(7,10,13,16, \\
19,22)\end{array}$ & & $1938-1939$ & $1938.5-1938$ & \\
\hline $\begin{array}{c}8(3,6,9,12, \\
14,18,21,24)\end{array}$ & $\mid \begin{array}{l}1935-1937.9 \\
1947-1949\end{array}$ & $1935,1947-1949$ & $1947-1949$ & \\
\hline $\begin{array}{l}8(3,6,9,12, \\
15,18,21,24)\end{array}$ & 1932-1934 & $1932-1934$ & $1932-1934$ & \\
\hline $\begin{array}{r}8(1,4,7,10,13 \\
16,19,22)\end{array}$ & $1940-1945$ & $1940-1945$ & $1940-1945$ & \\
\hline $\begin{array}{r}8(3,9,12,14 \\
15,18,21,24)\end{array}$ & 1946 & 1946 & 2946 & \\
\hline $\begin{array}{l}24(1-24) \\
4(1,7,23,19) \\
4(2,8,14,20)\end{array}$ & $\left|\begin{array}{l}1950-1953 \\
1954.1-1960.6 \\
1960.8-1983\end{array}\right|$ & \begin{tabular}{|l}
$1950-1953$ \\
$1954.1-1960.6$ \\
$1960.8-1983$
\end{tabular} & $\begin{array}{l}1950-1953 \\
1954.1-1960.6 \\
1960.8-1983\end{array}$ & $\begin{array}{l}195-1953 \\
1954.1-1960.6 \\
1960.7-1983\end{array}$ \\
\hline
\end{tabular}

D. Remarks:

1. Date divided time: $21120^{\circ}$ E meridian time durtng 1950-1953

19 local time durlag 1954.1-1960.6

20 Belftas time since 1960.7

2. The pressure has been corrected to the present hight. 
A. Main Data Sources
i. $1898-1950$
2. $1951-1980$
(67)
3. $1981-1983$
(68)
4. $1916-1936$
(13)
5. 1937-1943
(62)

B. Location of Station. Time Standard and Times of Observations

\begin{tabular}{|c|c|c|c|c|c|c|}
\hline $\begin{array}{l}\text { Observational } \\
\text { Period }\end{array}$ & Address & $\begin{array}{l}\text { Locatton } \\
\text { Lat.N }\end{array}$ & $\begin{array}{l}\text { a of stat: } \\
\mid \text { LoN.E }\end{array}$ & $|E(M)(P H)|$ & $\begin{array}{l}\text { Time zane } \\
\text { systan }\end{array}$ & $\begin{array}{l}\text { Tiges of } \\
\text { observations }\end{array}$ \\
\hline $1898-1899$ & $\begin{array}{l}\text { No.1 GuanTao } \\
\text { road }\end{array}$ & & & & $120^{\circ}$ E.M.T & $3(8,14,20)$ \\
\hline $\begin{array}{l}1900-1901 \\
1902-1905.5 \\
1905.6-1915\end{array}$ & $\begin{array}{l}\text { As above } \\
\text { As above } \\
\text { South d1str- }\end{array}$ & $36^{\circ} 04^{\prime}$ & $120^{\circ} 19^{\circ}$ & 77.0 & $\begin{array}{l}120^{\circ} \text { E.M.T } \\
120^{\circ} \text { E.M.T } \\
120^{\circ} \text { E.M.T }\end{array}$ & $\begin{array}{l}3(7,24,21) \\
3(7,24,21)\end{array}$ \\
\hline & $\begin{array}{l}\text { 1et Guan X1- } \\
\text { ang hill }\end{array}$ & & & & & \\
\hline $1916.6-1924.2$ & As abor & $36^{\circ} 04^{\circ}$ & $120^{\circ} 19^{\prime}$ & 77.0 & $120^{\circ}$ E.M.T & $\begin{array}{c}3(1,5,9,13 \\
17,21)\end{array}$ \\
\hline $\begin{array}{l}1924.3-1937.8 \\
1938.6-1945\end{array}$ & $\begin{array}{l}\text { As above } \\
\text { As above }\end{array}$ & $\begin{array}{ll}36^{\circ} & 04^{\circ} \\
36^{\circ} & 04^{\circ}\end{array}$ & $\begin{array}{l}120^{\circ} 19^{\prime} \\
120^{\circ} \\
19^{\prime}\end{array}$ & 77.0 & $\begin{array}{l}120^{\circ} \text { E.M.T } \\
120^{\circ} \text { E.M.T }\end{array}$ & $\begin{array}{c}24(6-21,22-5) \\
6(1,5,9,13 \\
17,21)\end{array}$ \\
\hline $1946-1950$ & As above & $36^{\circ} 04^{\circ}$ & $120^{\circ}$ i9' & 77.0 & $20^{\circ}$ E.M.T & $\mid \begin{array}{c}24(6-21,22-5) \\
17,21)\end{array}$ \\
\hline $1951-1953$ & $\begin{array}{l}\text { ElII-tap of } \\
\text { Guan Xians }\end{array}$ & $36^{\circ} 04^{\prime}$ & $120^{\circ} 19^{\circ}$ & $\begin{array}{l}77.0 \\
(78.6)\end{array}$ & $\begin{array}{c}\text { (Boijing } \\
\text { time) }\end{array}$ & $24(1-24)$ \\
\hline $1954-1959$ & As above & $36^{\circ} 04^{\circ}$ & $120^{\circ} 19^{\prime}$ & $\begin{array}{l}77.0 \\
(78.6)\end{array}$ & $\begin{array}{c}\text { (Beijing } \\
\text { time) }\end{array}$ & $4(1,7,13,19)$ \\
\hline $1960-$ & As above & $36^{\circ} 04^{\circ}$ & $120^{\circ} 19^{\prime}$ & $\begin{array}{l}77.0 \\
(78.6)\end{array}$ & $\begin{array}{c}\text { Beijing } \\
\text { time) }\end{array}$ & $4(1,7,13,29)$ \\
\hline $1960.7-1970$ & As above & $36^{\circ} 04^{\prime}$ & $120^{\circ} 19^{\circ}$ & $\begin{array}{l}77.0 \\
(78.6)\end{array}$ & $\begin{array}{c}\text { (Beijing } \\
\text { tima) }\end{array}$ & $4(2,8,14,20)$ \\
\hline $1971-1983$ & $\begin{array}{l}\text { South distr- } \\
\text { ict Fu Long } \\
\text { h111 (hill- } \\
\text { top) }\end{array}$ & $36^{\circ} 04^{\prime} \mid$ & $120^{\circ} 20^{\circ}$ & $(77.2)$ & $\begin{array}{c}\text { (Beifing } \\
\text { time) }\end{array}$ & $4(2,8,14,20)$ \\
\hline
\end{tabular}

C. Number of Observations Used for Calculating the Dally Mean

\begin{tabular}{|c|c|c|c|}
\hline Mean times & $\left|\begin{array}{c}\text { Mean pressure } \\
\text { (period) }\end{array}\right|$ & $\begin{array}{c}\text { Temperature } \\
\text { (period) }\end{array}$ & $\begin{array}{l}\text { Relative humadity } \\
\text { (period) }\end{array}$ \\
\hline $\begin{array}{l}1(10) \\
3(8,14,20) \\
3(7,14,21)\end{array}$ & $\begin{array}{l}1914-1915.2 \\
1907-1913 \\
1915.2-12\end{array}$ & $\begin{array}{l}2898.3-1899 \\
: 902-1915\end{array}$ & $\begin{array}{l}1898.6-1899 \\
1902-1915\end{array}$ \\
\hline $\begin{array}{c}\Xi(6,14,22) \\
6(2,6,10,14 \\
18,22) \\
24(1-24)\end{array}$ & \begin{tabular}{|l|}
$1916-1924.2$ \\
$1938-1945$ \\
$1924.3-1937.5$
\end{tabular} & $\begin{array}{l}1940-1946.2 \\
1916-1924.2 \\
1938-1939 \\
1924.3-1937.8 \\
1900-1901\end{array}$ & $\begin{array}{l}1940-1946.2 \\
1916-1924.2 \\
1938-1939 \\
1924.3-1937.8 \\
1900-1901\end{array}$ \\
\hline $\begin{array}{l}4(1,7,13,19) \\
4(2,8,14,20)\end{array}$ & $\begin{array}{l}1954-1960.6 \\
1960.7-1983\end{array}$ & $\begin{array}{l}1954-1960.6 \\
1960.7-1983\end{array}$ & $\begin{array}{l}: 954-1960.6 \\
: 960.7-1983\end{array}$ \\
\hline
\end{tabular}

D. Remarks: 
No. 2755591 La Sa

A. Matn Data Sources
1. $1935-1949$
2. 1935.7-1936 (pressure, humidity, cloud amount,
3. $1941-1949$
4. $1951-1960$
$1961-1970$
1971-1975
5. $1976-1980$
6. 1976-1980 (snow days)
1971-1980 (dominant winds)
7. 1961-1970 (mam/max/min temperature and cloud amount) (157)
8. $1981-1983$
and wind sperd) (15)
(69)(70)(71)
(159)
$(156$
(13)

B. Location of Station, TIme Standard and Times of Observations

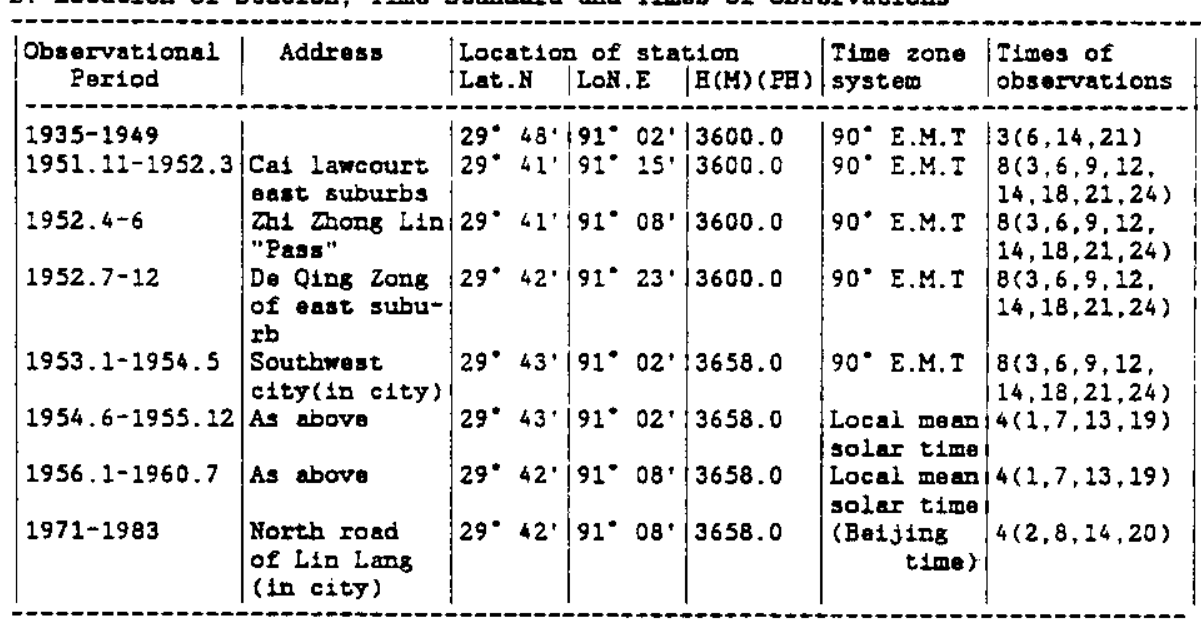

C. Number of Observations Used for Calculating the Daily Mean

\begin{tabular}{|c|c|c|c|c|}
\hline Mean times & $\left|\begin{array}{c}\text { Mean pressure } \\
\text { (period) }\end{array}\right|$ & $\begin{array}{c}\text { Temperature } \\
\text { (period) }\end{array}$ & $\begin{array}{l}\text { Rolative humidity } \\
\text { (pertod) }\end{array}$ & $\begin{array}{c}\text { Hind } \\
\text { (period) }\end{array}$ \\
\hline $\begin{array}{l}3(6,14,21) \\
8(3,6,9,12, \\
14,18,21,24)\end{array}$ & $1954.1-5$ & $\begin{array}{l}1935-1949 \\
1954.1-5\end{array}$ & $1954.1-5$ & $1954.1-5$ \\
\hline $\begin{array}{l}4(1,7,13,19) \\
4(2,8,14,20)\end{array}$ & $\left|\begin{array}{l}1954.6-1960.7 \mid \\
1960.8-1983\end{array}\right|$ & $\begin{array}{l}1954.6-1960.7 \\
1960.8-1983\end{array}$ & $\begin{array}{l}1954.6-1960.7 \\
1960.8-1983\end{array}$ & $\begin{array}{l}1954.6-1960.7 \\
1960.8-1983\end{array}$ \\
\hline
\end{tabular}

D. Remarixs :

1. Date divided time: $24-2490^{\circ} \mathrm{E}$ mean time during 1951.11-1954.5 19-19 local tean solar time (L.M.S.T) during 1954.1-1960.6 20-20 Beijing time since 1960.8 
Sio. 2856294 Creng Du

A. Main Data Sources

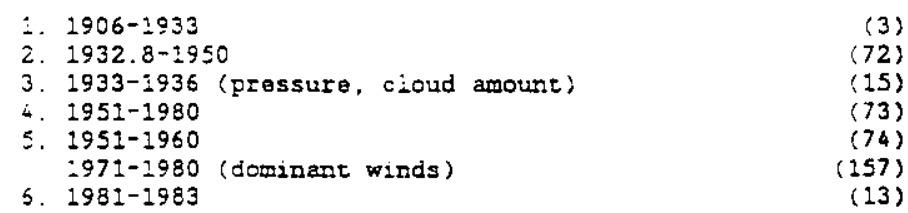

(15)

$(74)$

B. Location of Station, Time Standard and Itmes of Observations

\begin{tabular}{|c|c|c|c|c|c|c|}
\hline $\begin{array}{c}\text { Observational } \\
\text { Eerlod }\end{array}$ & Address & $\left|\begin{array}{l}\text { Locatior } \\
\text { Lat.N }\end{array}\right|$ & $\begin{array}{l}\text { of stat } \\
\text { |LoN.E }\end{array}$ & lon & $\begin{array}{l}\text { Time zono } \\
\text { system }\end{array}$ & $\begin{array}{l}\text { Times of } \\
\text { observations }\end{array}$ \\
\hline $\begin{array}{l}1906-1933 \\
1932-1934\end{array}$ & $\begin{array}{l}\text { Campus of } \mathrm{S} 1 \\
\text { Chuan unive- } \\
\text { asity }\end{array}$ & $\left|\begin{array}{ll}30^{\circ} & 38^{\prime} \\
30^{\circ} & 41^{\prime}\end{array}\right|$ & $\mid \begin{array}{ll}104^{\circ} & 02 \\
104^{\circ} & 15^{\prime}\end{array}$ & 503.1 & 105' E.M.T & $\begin{array}{c}8(3,6,9,12,15, \\
18,21,24)\end{array}$ \\
\hline $1935-1940$ & As above & $30^{\circ} 41^{\prime}$ & $104^{\circ} 15^{\prime}$ & 503.1 & $105^{\circ}$ E.M.T & $\begin{array}{r}8(3,6,9,12,14 \\
15,18,21,24)\end{array}$ \\
\hline$: 941-1946$ & $\begin{array}{l}\text { Dong Sha He } \\
\text { Bao }\end{array}$ & $30^{\circ} 40^{\prime}$ & $104^{\circ} 04^{\prime}$ & 553.4 & 105'E.M.I|2 & $24(1-24)$ \\
\hline $\begin{array}{l}1947-1950 \\
1951.1-8\end{array}$ & $\begin{array}{l}\text { As above } \\
\text { Soall Ilan } \\
\text { Thu street } \\
\text { (out c1ty) }\end{array}$ & $\begin{array}{l}30^{\circ} 40^{\circ} \\
30^{\circ} 40^{\circ}\end{array}$ & $\begin{array}{l}104^{\circ} 04^{\prime} \\
104^{\circ} \\
4^{\prime}\end{array}$ & $\begin{array}{l}526.0 \\
491.1\end{array}$ & $\mid \begin{array}{l}205^{\circ} \text { E.M.T } \\
205^{\circ} \text { E.M.T }\end{array}$ & $\begin{array}{l}24(1-24) \\
24(1-24)\end{array}$ \\
\hline $\begin{array}{l}2951.9-1953 \\
1954-1957.4 \\
1957.5-1960.7\end{array}$ & $\begin{array}{l}\text { As above } \\
\text { As above } \\
\text { Guang Elua } \\
\text { village west } \\
\text { (suburb) }\end{array}$ & $\begin{array}{ll}30^{\circ} & 40^{\prime} \\
30^{\circ} & 40^{\circ} \\
30^{\circ} & 40^{\circ}\end{array}$ & 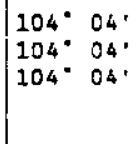 & $\begin{array}{l}497.9 \\
497.9 \\
505.9\end{array}$ & $\begin{array}{l}105^{\circ} \text { E.M.T } \\
\text { Local time } \\
\text { Local time }\end{array}$ & $\left\{\begin{array}{l}24(1-24) \\
4(1,7,23,10) \\
4(1,7,13,19)\end{array}\right.$ \\
\hline$: 960.8-1970$ & As above & $30^{\circ} 40^{\circ}$ & $104^{\circ} 04^{\circ}$ & 507.6 & $\begin{array}{c}(\text { Beijing } \\
\operatorname{tim} \theta)\end{array}$ & $4(2,8,14,20)$ \\
\hline $1971-198^{\prime}$ & As above & $30^{\circ} 40^{\circ}$ & $104^{\circ} 01^{\prime}$ & 507.6 & $\left(\begin{array}{c}\text { (Beijing } \\
\text { timo })\end{array}\right.$ & $4(2,8,14,20)$ \\
\hline 1982- & As bove & $30^{\circ} 40^{\circ}$ & $104^{\circ} 01^{\prime}$ & $\begin{array}{l}506.1 \\
(507.6)\end{array}$ & $\begin{array}{c}\text { (Beijing } \\
\text { tioe })\end{array}$ & $4(2,8,14,20)$ \\
\hline $1983-$ & As above & $30^{\circ} 40^{\circ}$ & $204^{\circ} 01^{\prime}$ & $\begin{array}{l}506.1 \\
(507.3)\end{array}$ & $\begin{array}{c}(B \theta 1 j \pm \operatorname{tng} \\
t \perp \theta)\end{array}$ & $4(2,8,14,20)$ \\
\hline
\end{tabular}

2. Wumber of Cbservations Used for Calculating the Daily Mean

\begin{tabular}{|c|c|c|c|}
\hline Yean trmes & $\begin{array}{l}\text { Mean pressure } \\
\text { (period) }\end{array}$ & $\begin{array}{l}\text { Temperature } \\
\text { (period) }\end{array}$ & $\begin{array}{l}\text { Relative humudity } \\
\text { (period) }\end{array}$ \\
\hline $\begin{array}{l}3(6,24,21) \\
6(6,14,21) \\
24(1-24)\end{array}$ & $\begin{array}{l}1934 \\
: 935-1940 \\
: 941-1942 \\
: 947-1953\end{array}$ & $\begin{array}{l}1932-1934 \\
1935-1940 \\
1941-1953\end{array}$ & $\begin{array}{l}1932-1934 \\
1935-1941.2 \\
1941.3-1953\end{array}$ \\
\hline $\begin{array}{l}-(1,7,23,19) \\
4(2,8,14,20)\end{array}$ & $\begin{array}{l}1954-1960.7 \\
1960.8-1983\end{array}$ & $\begin{array}{l}1954-1960.7 \\
: 960.8-1983\end{array}$ & $\begin{array}{l}1954-1960.7 \\
1960.8-1983\end{array}$ \\
\hline
\end{tabular}

2. Remarixs :

. Temaries: 
A. Main Data Sources
1. $1924-1950$
2. 1951-1970
3. 1971-1980
4. 1951-1980
5. 1951-1960
$1971-1980$
(2) (3) (4)
(75) (76)
(13)
(77)
(12)
(156)
6. $1981-1983$

B. Location of Station, Time Standard and Times of Observations

\begin{tabular}{|c|c|c|c|c|c|c|c|c|}
\hline $\begin{array}{l}\text { Observational } \\
\text { Period }\end{array}$ & Address & $\begin{array}{l}\text { Loe: } \\
\text { Lat. }\end{array}$ & $\begin{array}{l}a t 1 \\
. A\end{array}$ & $\begin{array}{l}\text { D of } \\
\text { Lok. }\end{array}$ & & |: $100(\mathrm{M})(\mathrm{PH})$ & $\left\{\begin{array}{l}\text { Time zone } \\
\text { systam }\end{array}\right.$ & $\begin{array}{l}\text { TLmes of } \\
\text { observations }\end{array}$ \\
\hline $\begin{array}{l}1924.2-1950 \\
1938-1950 \\
1926-1935 \\
1939.3-1950.3 \\
1951.1-3\end{array}$ & $\begin{array}{l}\text { Small temple } \\
\text { Y1DanTu airp- } \\
\text { ort (coumery- } \\
\text { s1de) }\end{array}$ & $\mid \begin{array}{l}27^{\circ} \\
27^{\circ} \\
27^{\circ} \\
27^{\circ} \\
27^{\circ}\end{array}$ & $\begin{array}{l}53^{\prime} \\
53^{\prime} \\
55^{\prime} \\
53^{\prime} \\
53^{\prime}\end{array}$ & $\begin{array}{l}102^{\circ} \\
102^{\circ} \\
102^{\circ} \\
102^{\circ} \\
102^{\circ}\end{array}$ & $\begin{array}{l}18^{\circ} \\
18^{\circ} \\
18^{\circ} \\
18^{\prime} \\
18^{\prime}\end{array}$ & $\mid$\begin{tabular}{c}
1517.0 \\
1517.0 \\
\hdashline 1582.8 \\
1582.8
\end{tabular} & $\left|\begin{array}{ll}120^{\circ} & \text { E.M.T } \\
120^{\circ} & \text { E.M.T } \\
120^{\circ} & \text { E.M.T } \\
120^{\circ} & \text { E.M.T } \\
105^{\circ} & \text { E.M.T }\end{array}\right|$ & $\mid \begin{array}{l}3(6,14,21) \\
3(6,14,21) \\
3(6,14,21) \\
3(6,14,21) \\
6(6,9,12 \\
14,18,21)\end{array}$ \\
\hline $\begin{array}{l}1951.4-7 \\
1951.8-12 \\
1954-1960.7\end{array}$ & $\begin{array}{l}\text { As above } \\
\text { As above } \\
\text { North tower } \\
\text { temple } \\
\text { (in city) }\end{array}$ & $\begin{array}{l}27^{\circ} \\
27^{\circ} \\
27^{\circ}\end{array}$ & $\begin{array}{l}53^{\prime} \\
53^{\prime} \\
53^{\prime}\end{array}$ & $\begin{array}{l}102^{\circ} \\
102^{\circ} \\
102^{\circ}\end{array}$ & $\begin{array}{l}18 \\
02 \\
02\end{array}$ & $\begin{array}{l}1582.8 \\
1582.8 \\
1590.7\end{array}$ & $\mid \begin{array}{l}105^{\circ} \text { E.M.I } \\
105^{\circ} \text { E.M.I } \\
\text { Local mean } \\
\text { golar tims }\end{array}$ & $\left\{\begin{array}{l}24(1-24) \\
24(1-24) \\
4(1,7,13,19)\end{array}\right.$ \\
\hline $1960-1968.6$ & As above & $27^{\circ}$ & $53^{\prime}$ & $102^{\circ}$ & $02{ }^{\circ}$ & 1590.7 & $\begin{array}{c}(801 j \pm 28 \\
t 100)\end{array}$ & $4(2,8,14,20)$ \\
\hline $1968.7-11$ & As ebove & $27^{\circ}$ & $53^{\prime}$ & $102^{\circ}$ & $02^{\circ}$ & 1590.7 & $\left(\begin{array}{c}(B) i j \pm n g \\
t 1 m e\end{array}\right)$ & $3(8,14,20)$ \\
\hline $1968.12-1978$ & As above & $27^{\circ}$ & $53^{\prime}$ & $102^{\circ}$ & $02{ }^{\prime}$ & 1590.7 & $\begin{array}{c}(B e d j 108 \\
t 100)\end{array}$ & $4(2,8,14,20)$ \\
\hline $1979-1982.3$ & As above & $27^{\circ}$ & $54^{\prime}$ & $102^{\circ}$ & $16^{\circ}$ & $\begin{array}{l}1590.7 \\
(1598.9)\end{array}$ & $\begin{array}{c}\text { (Beijins } \\
\text { time) }\end{array}$ & $4(2,8,14,20)$ \\
\hline $1982.4-1983$ & As above & $27^{\circ}$ & $54^{\prime}$ & $102^{\circ}$ & $16^{\circ}$ & $\begin{array}{l}1590.9 \\
(1598.9)\end{array}$ & $\begin{array}{c}(B e \pm j \operatorname{lng} \\
\text { time })\end{array}$ & $4(2,8,14,20)$ \\
\hline
\end{tabular}

C. Number of Observations Used for Calculating the Daily Mean

\begin{tabular}{|c|c|c|c|c|}
\hline Mean times & $\begin{array}{c}\text { Mean pressure } \\
\text { (period) }\end{array}$ & $\begin{array}{l}\text { Temperature } \\
\text { (period) }\end{array}$ & $\mid \begin{array}{c}\text { Relative huanidity } \\
\text { (pertod) }\end{array}$ & $\begin{array}{l}\text { Wind } \\
\text { (period) }\end{array}$ \\
\hline $\begin{array}{l}3(6,14,21) \\
6(6,9,12,14 ; \\
13,21) \\
16(6-21) \\
24(1-24) \\
4(1,7,13,19) \\
4(2,8,14,20)\end{array}$ & $\begin{array}{l}1951.4-1953 \\
1954-1960.7 \\
1960.8-1983\end{array}$ & $\begin{array}{l}1938-1939.1 \\
1939.3-1941 \\
1942-1951\end{array}$ & $\begin{array}{l}1951.4-1953 \\
1954-1960.7 \\
1960.8-1983\end{array}$ & $\begin{array}{l}1951.1-3 \\
1954.4-7 \\
1951.8-1953 \\
1954-1960.7 \\
1960.8-1983\end{array}$ \\
\hline
\end{tabular}

D. Remariks :

1. Differences of wind direction. pressure, etc. occur around 1954 due to a change of station location. 
A. Main Data Sources

$\begin{array}{lc}\text { ¿. } 1911-1938 \text { (Frecipitation) } & (3)(80) \\ \text { 2. } 1916-1941 & (2) \\ \text { 3. } 1951-1980 & (78) \\ \text { 4. } 1981-1983 & (13) \\ \text { 5. } 1981-1936 & (15)\end{array}$

3. Location of Station, Tlme Standard and Ilmes of Observations

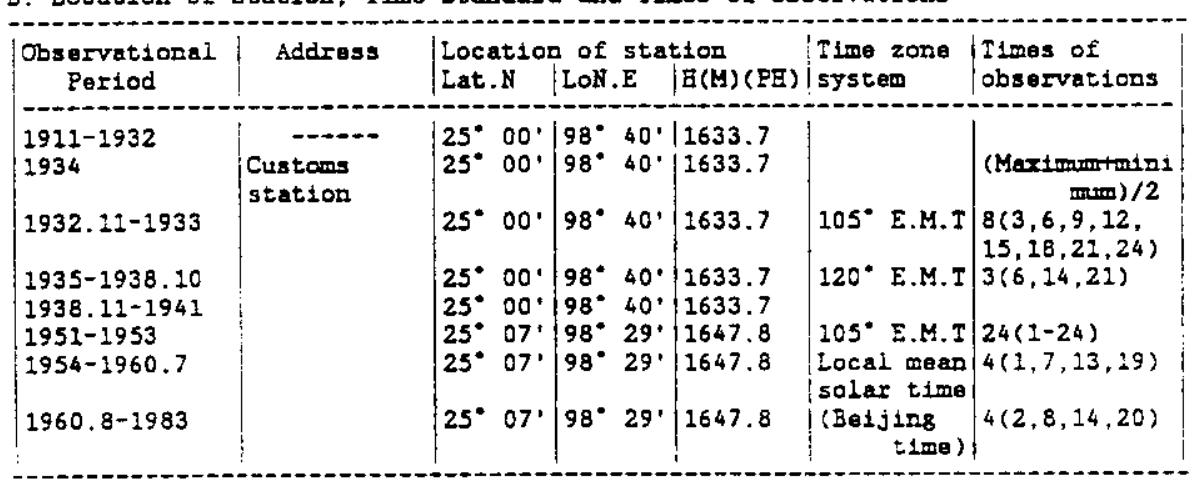

C. Number of Observations Used for Calculating the Dafly Mann

\begin{tabular}{|c|c|c|c|}
\hline Mean times & $\begin{array}{c}\text { Mean pressure } \\
\text { (period) }\end{array}$ & $\begin{array}{c}\text { Temperature } \\
\text { (period) }\end{array}$ & $\begin{array}{l}\text { Relative humidity } \\
\text { (period) }\end{array}$ \\
\hline $\begin{array}{c}\text { (Maximmini } \\
\text { mum }) / 2 \\
8(3,6,9,12,14, \\
18,21,24) \\
3(6,14,21) \\
8(3,6,9,12,14, \\
18,21,24) \\
4(1,7,13,19) \\
4(2,8,14,20)\end{array}$ & $\begin{array}{l} \\
1951-1953 \\
1954-1960.7 \\
: 960.8-1983\end{array}$ & $\begin{array}{l}1916-1932.10 \\
1938.11-1941 \\
1934 \\
1932.11-1933 \\
1935-1938.10 \\
1951-1953 \\
1954-1960.7 \\
1960.8-1983\end{array}$ & $\begin{array}{l}1951-1953 \\
1954-1960.7 \\
1960.8-1983\end{array}$ \\
\hline
\end{tabular}

D. Remarks :

¡. Old name : Feng Tye 
No. 3156778 Kun Ming

A. Main Data Sources
1. 1901-1936
2. $1928-1950$
(3)
(79)
4. 1981-1983
$(78)(80)$
(13)

B. Location of Station. Time Standard and Times of Observations

\begin{tabular}{|c|c|c|c|c|c|c|}
\hline $\begin{array}{c}\text { Observational } \\
\text { Perlod }\end{array}$ & Address & $\left|\begin{array}{l}\text { Locat10o } \\
\text { Lat. } \mathbf{N}\end{array}\right|$ & $\begin{array}{l}\text { n of stat: } \\
\text { |LoN.E }\end{array}$ & $\mid \mathrm{E}(\mathrm{M})(\mathrm{PE})$ & $\mid \begin{array}{l}r \text { 1me zone } \\
\text { system }\end{array}$ & $\left|\begin{array}{l}\text { Times of } \\
\text { observations }\end{array}\right|$ \\
\hline $\begin{array}{l}1901-1936 \\
1928-1936.5 \\
1936.6-1938.4\end{array}$ & $\begin{array}{l}\text { Qianju stroet } \\
\text { Yi-De meteor- } \\
\text { ological sta- } \\
\text { tion }\end{array}$ & $\left|\begin{array}{cc}25^{\circ} & 02 \\
25^{\circ} & 03^{\prime}\end{array}\right|$ & $\mid \begin{array}{ll}102^{\circ} & 41^{\prime} \\
102^{\circ} & 42^{\prime}\end{array}$ & $\begin{array}{l}1893.0 \\
1922.1\end{array}$ & $\left|\begin{array}{ll}105^{\circ} & \text { E.M.T } \\
105^{\circ} & \text { E.M.T }\end{array}\right|$ & $\mid \begin{array}{c}3(6,14,21) \\
24(6-21, \\
22-5)\end{array}$ \\
\hline 1946 & $W u-J i a-B a$ & $25^{\circ} 02^{\circ}$ & $102^{\circ} 43^{\circ}$ & 1902.0 & $105^{\circ}$ E.M.I & $\begin{array}{l}8(3,6,9,12 \\
15,18,21,24)\end{array} \mid$ \\
\hline $\begin{array}{l}1947-1951.8 \\
1951.9-12 \\
1952.1-8 \\
1952.9-12 \\
1953-1960.7\end{array}$ & $\begin{array}{l}\omega u-J i a-B a \\
W u-J i a-B a \\
W u-J i a-B a \\
W u-J i a-B a\end{array}$ & \begin{tabular}{ll|}
$25^{\circ}$ & 02 \\
$25^{\circ}$ & 02 \\
$25^{\circ}$ & 02 \\
$25^{\circ}$ & 02 \\
$25^{\circ}$ & $01^{\circ}$
\end{tabular} & 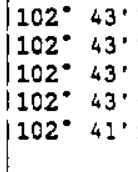 & $\begin{array}{l}1902.0 \\
1961.0 \\
1893.4 \\
1891.0 \\
1891.4\end{array}$ & $\begin{array}{l}105^{\circ} \text { E.M.T } \\
105^{\circ} \text { E.M.I } \\
105^{\circ} \text { E.M.I } \\
105^{\circ} \text { E.M.I } \\
\text { Local mean } \\
\text { solar I1me }\end{array}$ & $\begin{array}{l}24(1-24) \\
24(1-24) \\
24(1-24) \\
24(1-24) \\
4(1,7,13,19)\end{array}$ \\
\hline $1960.8-1983$ & & $25^{\circ} 01^{\circ}$ & $102^{\circ} 41^{\prime}$ & 1891.4 & 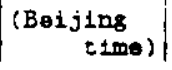 & $4(2,8,14,20)$ \\
\hline
\end{tabular}

C. Number of observations used for calculating the daily mean

\begin{tabular}{|c|c|c|c|}
\hline Mean times & $\begin{array}{c}\text { Mean pressure } \\
\text { (per1od) }\end{array}$ & $\begin{array}{c}\text { Temperature } \\
\text { (period) }\end{array}$ & $\begin{array}{l}\text { Relative bumidity } \\
\text { (pertod) }\end{array}$ \\
\hline (Maximint & $-\ldots$ & $\mid 1921-1927$ & ----- \\
\hline $\begin{array}{l}3(6,14,21) \\
3(6,15,21) \\
24(1-24)\end{array}$ & $\begin{array}{l}1929-1938.4 \\
1946 \\
1947-1953\end{array}$ & $\begin{array}{l}1928-1938.4 \\
1946 \\
1947-1953\end{array}$ & $\begin{array}{l}1930-1936.4 \\
1946 \\
1937-1938.4 \\
1947-1953\end{array}$ \\
\hline $\begin{array}{l}4(1,7,13,19) \\
4(2,8,14,20)\end{array}$ & $\begin{array}{l}1953-1960.7 \\
1960.8-1983\end{array}$ & $\begin{array}{l}1953-1960.7 \\
1960.8-1983\end{array}$ & $\begin{array}{l}1953-1960.7 \\
1960.8-1983\end{array}$ \\
\hline
\end{tabular}

D. Remarks : 
No. $32 \$ 7006$ Tian Shui

A. Main Data Sources

$\begin{array}{ll}\text { 2. } 1935.9-1950 & (81) \\ \text { 2. } 1951-1969 & (82) \\ \text { 3. } 1970 \text { (temperature, wind, precipitation and sunshine) } & (10)(9)(7) \\ \text { 4. } 1935.9-1940 \text { (moan temperature, humiditg, snow days) } & (31) \\ 1942-1970 & (83) \\ \text { 5. } 1971-1980 & (13) \\ \text { 6. } 1981-1983 & (12) \\ \text { 7. } 1951-1962 \text { (cloud amount) } & (156) \\ 1963-1970 & \end{array}$

B. Location of Station, Time Standard and Times of Observations

\begin{tabular}{|c|c|c|c|c|c|c|}
\hline $\begin{array}{l}\text { boservational } \\
\text { Period }\end{array}$ & Address & $\begin{array}{l}\text { Location } \\
\text { Lat.N }\end{array}$ & $\begin{array}{l}\text { of sta } \\
\text { LoN. } \mathrm{E}\end{array}$ & $|E(M)(P Z)|$ & $\begin{array}{l}\text { Ilme zone } \\
\text { system }\end{array}$ & $\begin{array}{l}\text { Times of } \\
\text { observations }\end{array}$ \\
\hline $\begin{array}{l}1935.9-1938.12 \\
1940.4-1940.11 \\
1942.1-1942.5 \\
1942.6-1944.5\end{array}$ & $\mid \begin{array}{l}\text { Duan } X I \text { Wang } \\
\text { Ji a Ya } \\
\text { As above } \\
\text { As above }\end{array}$ & $\left|\begin{array}{ll}34^{\circ} & 36^{\prime} \\
34^{\circ} & 36^{\prime} \\
34^{\circ} & 36^{\prime}\end{array}\right|$ & $\left|\begin{array}{ll}105^{*} & 34^{\prime} \\
205^{\circ} & 34^{\prime}\end{array}\right|$ & $\begin{array}{l}1174.0 \\
1174.0\end{array}$ & $\left|\begin{array}{l}120^{\circ} \text { E.M.I } \\
120^{\circ} \text { E.M.T } \\
120^{\circ} \text { E.M.T }\end{array}\right|$ & $\mid \begin{array}{l}24(1-24) \\
7(6,9,12,14 \\
3(6,14,21) \\
5(6,9,12,18\end{array}$ \\
\hline $1945.1-7$ & As above & $34^{*} 36^{\prime}$ & $105^{\circ} 34^{\circ}$ & 1274.0 & $120^{\circ}$ E.M.T & $\begin{array}{r}9(6,7,9,12 \\
13,14,18\end{array}$ \\
\hline $1945.8-1949.7$ & As above & $34^{\circ} 36^{\prime}$ & $105^{\circ} 34^{\prime}$ & 1174.0 & $220^{\circ}$ E.M.T & $\begin{array}{r}6(6,9,12,15 \\
18,21)\end{array}$ \\
\hline$\therefore 949.8-1950.12$ & $\begin{array}{l}\text { Be Nan Liang } \\
\text { Jla Fins }\end{array}$ & $34^{\circ} 36^{\circ}$ & $105^{\circ} 34^{\prime}$ & 1202.2 & $120^{\circ}$ E.M.T & $\begin{array}{r}6(6,9,12,15 \\
18,21)\end{array}$ \\
\hline $1951.1-1952.5$ & As above & $34^{\circ} 36^{\prime}$ & $105^{\circ} 34^{\circ}$ & 1225.0 & 105" E.M.T & $\begin{array}{r}8(3,6,9,12 \\
15,18,21,24)\end{array}$ \\
\hline $1952.6-1953.12$ & $\begin{array}{l}\text { Dong ErShilt } \\
\text { Pu Zhao Jia } \\
\text { village }\end{array}$ & $34^{\circ} 29^{\circ}$ & $106^{\circ} 01^{\circ}$ & 1096.1 & $105^{\circ}$ E.M.T & $\begin{array}{r}8(3,6,9,12, \\
15,18,21,24)\end{array}$ \\
\hline $1954.1-12$ & As above & $34^{\circ} 29^{\prime}$ & $106^{\circ} 01^{\prime}$ & 1096.1 & $\begin{array}{l}\text { Local mean } \\
\text { solar time }\end{array}$ & $4(1,7,13,19)$ \\
\hline $1955.2-1960.7$ & $\begin{array}{l}\text { East outsida } \\
\text { WuLiPu Jing } \\
\text { J1a village }\end{array}$ & $34^{\circ} 35^{\prime}$ & $105^{\circ} 45^{\prime}$ & 1131.7 & \begin{tabular}{|} 
Local mean \\
solar time
\end{tabular} & $4(1,7,13,19)$ \\
\hline $1960.8-1983$ & As thove & $34^{\circ} 35^{\prime}$ & $105^{\circ} 45^{\prime}$ & 1131.7 & $\begin{array}{c}\text { (Beijing } \\
\text { timo })\end{array}$ & $4(2,8,14,20)$ \\
\hline
\end{tabular}

z. Number of Observations Used for Calculating the Daily Mean

\begin{tabular}{|c|c|c|c|c|}
\hline Mean E2mes & $\begin{array}{c}\text { Mean pressure } \\
\text { (period) }\end{array}$ & $\begin{array}{c}\text { Temperature } \\
\text { (period) }\end{array}$ & $\begin{array}{l}\text { Relative humidity } \\
\text { (period) }\end{array}$ & $\begin{array}{l}\text { Wind } \\
\text { (period) }\end{array}$ \\
\hline $\begin{array}{l}3(6,14,21) \\
3(3,6,9,12, \\
15,28,22,24) \\
4(1,7,23,19) \\
4(2,3,14,20)\end{array}$ & $\begin{array}{l}1935.9-1950.12 \\
1951-1953 \\
1: 954.1-1960.7 \\
1960.8-1983\end{array}$ & $\begin{array}{l}1935.9-1950.12 \\
=951-1953 \\
1954.1-1960.7 \\
1960.8-1983\end{array}$ & $\begin{array}{l}1935.9-1950.12 \\
1951-1953 \\
1954.1-1960.7 \\
1960.8-1983\end{array}$ & $\mid$\begin{tabular}{l|}
$1935.9-1950.12$ \\
$1951-1953$ \\
$1954.1-1960.7$ \\
$1960.8-1983$
\end{tabular} \\
\hline
\end{tabular}

2. Remarks:

\footnotetext{
$\therefore$ Date divided time: $22120^{\circ} \mathrm{E}$ mean time during $1935-1950$

$24105^{\circ} \mathrm{E}$ mean time during 2951-1953.

ig local mean solar time (L.M.S.T.) during 1954-1960.7

20 Beijing time since 1960.8
} 
A. Main Data Sources

$\begin{array}{lr}\text { 1. } 1922-1950 & (84) \\ \text { 2. } 1951-1960 & (85) \\ \text { 3. } 1961-1970 & (86) \\ \text { 4. } 1971-1980 & (87) \\ \text { 5. } 1981-1983 & (13) \\ \text { 6. } 1961-1970 & (157)\end{array}$

B. Location of Station, Time Standard and Iimes of Observations

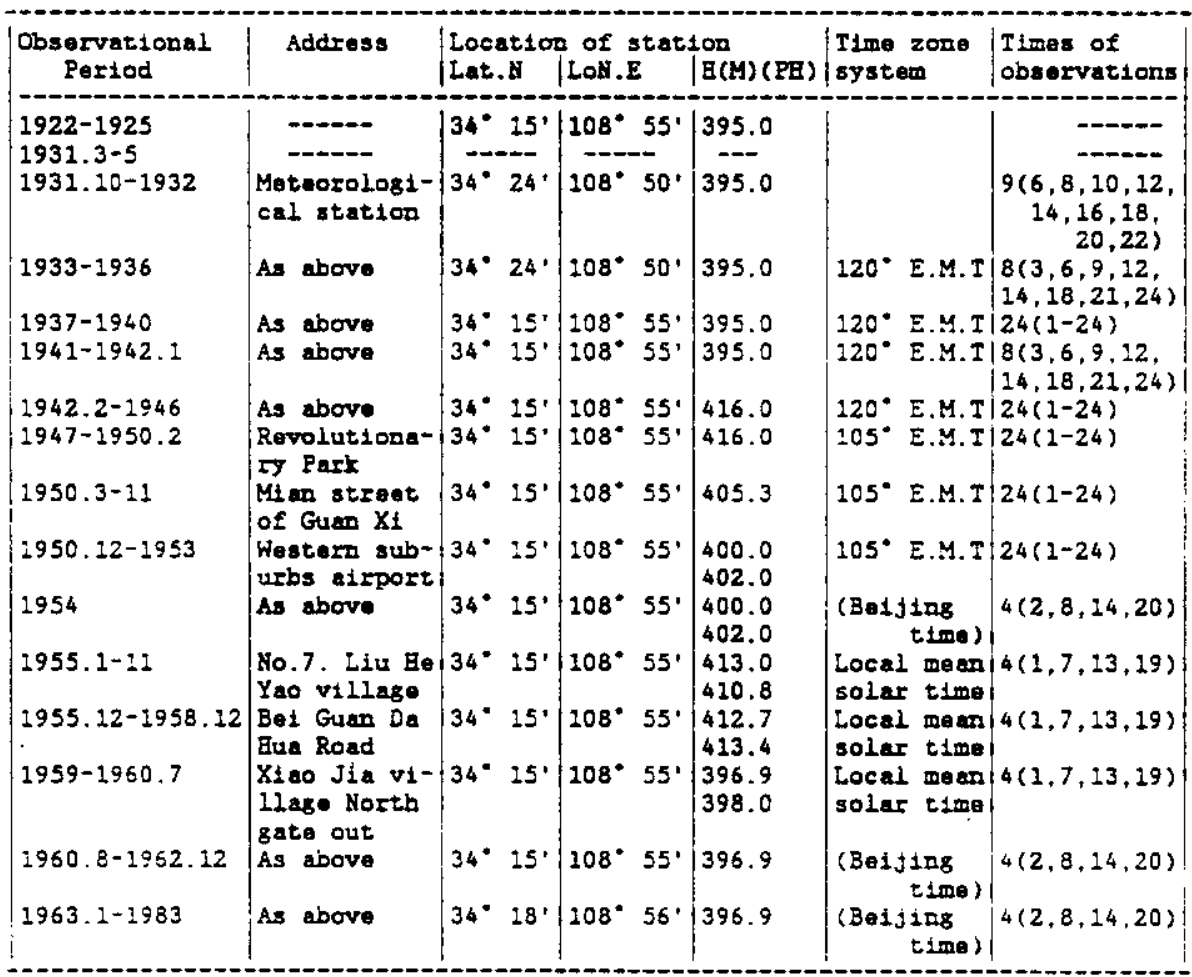

c. Number of Observations Used for Calculatins the Daily Mean

\begin{tabular}{|c|c|c|c|}
\hline Mean times & $\begin{array}{c}\text { Mean pressure } \\
\text { (period) }\end{array}$ & $\begin{array}{l}\text { Temperature } \\
\text { (period) }\end{array}$ & $\begin{array}{l}\text { Relative humidity } \\
\text { (period) }\end{array}$ \\
\hline $\begin{array}{c} \\
6(6,9,12,15, \\
i 8,21) \\
9(6,8,10,12,14, \\
16,18,20.22) \\
8(3,6,9,12.15, \\
\quad 38,21.24) \\
3(6,14,21) \\
24(1-24) \\
4(1,7,13,19) \\
4(2,8,14.20)\end{array}$ & $\begin{array}{l}1934-1950.11 \\
1950.12-1953 \\
1955-1960.7 \\
1954,1960.8-1983\end{array}$ & $\begin{array}{l}1922-1925 \\
1931-1933 \\
1931.3-5 \\
1931.10-1932 \\
1933 \\
1934-1936 \\
1950.12-1953 \\
1955-1960.7 \\
1954.1960 .8-1983\end{array}$ & $\begin{array}{l}1934-1936 \\
1950.12-1953 \\
1955-1960.7 \\
1954,1960.8-1983\end{array}$ \\
\hline
\end{tabular}

D. Remarixs : 
A. Main Data Sources

$\begin{array}{ll}\text { ․ } 1930-1935 & (3)(15) \\ \text { 2. } 1935-1950 & (88) \\ \text { 3. } 1951-1960 & (89) \\ \text { 4. } 1961-1962 & (12) \\ 1963-1967 & (7)(6)(5)(10)(11)(8)(156)(90) \\ \text { 5. } 1971-1980 & (159) \\ \text { 6. } 1981-1983 & (13) \\ \text { 7. } 1952.12-1953 & (12)\end{array}$

B. Location of Station, Time Standard and Iifes of Observations

\begin{tabular}{|c|c|c|c|c|c|c|}
\hline $\begin{array}{c}\text { Observational } \\
\text { Period }\end{array}$ & Addres: & $\begin{array}{l}\text { Location } \\
\text { Lat.N }\end{array}$ & $\begin{array}{l}\text { of stati } \\
\mid \text { LoN.E }\end{array}$ & $\begin{array}{l}\text { Ion } \\
\mathrm{H}(\mathrm{H})(\mathrm{PH})\end{array}$ & $\begin{array}{l}\text { Time zono } \\
\text { system }\end{array}$ & $\begin{array}{l}\text { Tleses of } \\
\text { observations }\end{array}$ \\
\hline $\begin{array}{l}930-1935.5 \\
935.6-1938.5\end{array}$ & Wu Li Pu & $\mid \begin{array}{ll}34^{\circ} & 35^{\prime} \\
34^{\circ} & 50^{\prime}\end{array}$ & $\left|\begin{array}{ll}113^{\circ} & 40^{\prime} \\
113^{\circ} & 55^{\prime}\end{array}\right|$ & $\mid \begin{array}{l}107.0 \\
107.0\end{array}$ & $\left|\begin{array}{ll}120^{\circ} & \text { E.M.T. } \\
120^{\circ} & \text { E.M.I }\end{array}\right|$ & $\left\{\begin{array}{l}8(3,6,9,12 \\
14,18,21,24)\end{array}\right.$ \\
\hline $1950.5-12$ & $\begin{array}{l}\text { Out of east } \\
\text { c1ty }\end{array}$ & $34^{\circ} 45^{\prime}$ & $113^{\circ} 35^{\circ}$ & 80.6 & $: 20^{\circ}$ E.M.I & $24(6-21.22-5)$ \\
\hline $1951-1953$ & $\begin{array}{l}\text { Eastern sub- } \\
\text { urb alrport }\end{array}$ & $34^{\circ} 45^{\prime}$ & $113^{\circ} 35^{\prime}$ & 80.6 & $120^{\circ}$ E.M.I & $24(1-24)$ \\
\hline $\begin{array}{l}1954- \\
1955-1960.6\end{array}$ & $\begin{array}{l}\text { As above } \\
\text { Q1u viliage } \\
\text { of eastern } \\
\text { suburb }\end{array}$ & $34^{\circ} 45^{\prime}$ & $\begin{array}{l}113^{\circ} 35^{\prime} \\
113^{*} 39^{\circ}\end{array}$ & $\begin{array}{l}180.6 \\
109.0\end{array}$ & $\begin{array}{l}: 20^{\circ} \text { E.M.T } \\
\text { Socal mean } \\
\text { solar time }\end{array}$ & $\left\{\begin{array}{l}4(2,8,14,20) \\
4(1,7,13,19)\end{array}\right.$ \\
\hline $1960.7-$ & As above & $34^{\circ} 43^{\circ}$ & $113^{\circ} 39^{\circ}$ & 1209.0 & $\left(\begin{array}{c}\text { (Beijing } \\
\text { ine })\end{array}\right.$ & $4(2,8,14,20)$ \\
\hline $1971-1983$ & As above & $34^{\circ} 43^{\circ}$ & $113^{\circ} 39^{\prime}$ & 120.4 & $\begin{array}{c}(B e 1 j \pm z 8 \\
\text { :1me })\end{array}$ & $4(2,8,14,20)$ \\
\hline
\end{tabular}

C. Number of Observations Used for Calculating the Daily Mean

\begin{tabular}{|c|c|c|c|c|}
\hline Mean times & $\begin{array}{c}\text { Mean pressure } \\
\text { (period) }\end{array}$ & $\begin{array}{l}\text { Temperature } \\
\text { (pertod) }\end{array}$ & $\mid \begin{array}{c}\text { Relative humidity } \\
\text { (period) }\end{array}$ & $\begin{array}{l}\text { Wind } \\
\text { (period) }\end{array}$ \\
\hline $\begin{array}{l}3(6,14,21) \\
24(1-24) \\
4(1,7,13,19) \\
4(2,8,14,20) \\
4(2,8,14,20)\end{array}$ & $\mid \begin{array}{l}1935.6-1937 \\
1938.1- \\
1950.5-1953 \\
1955.1-1960.6 \\
1954 \\
2960.7-1983\end{array}$ & $\begin{array}{l}1935.6-1937 \\
1938.1-5 \\
1950.5-1953 \\
1955.1-1960.6 \\
1954 \\
1960.7-1983\end{array}$ & $\begin{array}{l}1935.6-1937 \\
1938.1-5 \\
1950.5-1953 \\
1955.1-1960.6 \\
1954 \\
1960.7-1983\end{array}$ & $\begin{array}{l}1950.5-1953 \\
1955.1-1960.6 \\
1954 \\
1960.7-1983\end{array}$ \\
\hline
\end{tabular}

J. Remariks:

T.7e data at 2200 - 500 hours were taken from autographic recorcs. 
A. Main Data Sources
1. $1935-1950$
2. $1951-1960$
3. $1961-1970$
4. $1971-1980$
5. $1981-1983$
6. 1955-1956 (dominant winds)
$(3)(2)(4)$
(91)
$(6)(7)(8)(9)(10)(11)(156)$
$(159)(92)$
(13)
(12)

B. Location of Station, IIme Standard and Times of Observations

\begin{tabular}{|c|c|c|c|c|c|c|}
\hline $\begin{array}{l}\text { Observational } \\
\text { Period }\end{array}$ & Address & \begin{tabular}{|l} 
Loeat 10 \\
Lat. N
\end{tabular} & $\begin{array}{l}\text { of stat: } \\
\mid \text { LoN.E }\end{array}$ & | $\mathrm{B}(\mathrm{M})(\mathrm{PE})$ & \begin{tabular}{|l} 
Pime zone \\
system
\end{tabular} & $\begin{array}{l}\text { T1mes of } \\
\text { observations }\end{array}$ \\
\hline $\begin{array}{l}1935-1 \\
1932-1950 \\
1951-1952.1 \\
1952.2-1953\end{array}$ & & $\begin{array}{l}32^{\circ} 56^{\prime} \\
33^{\circ} \text { O5' } \\
33^{\circ} \text { O5' } \\
33^{\circ} \text { O5 }\end{array}$ & $\left|\begin{array}{ll}107^{\circ} & 12 \\
107^{\circ} & 04^{\circ} \\
107^{\circ} & 10^{\circ} \\
107^{\circ} & 10^{\circ}\end{array}\right|$ & $\begin{array}{c}520.0 \\
510.1 \\
(511.4) \\
510.1\end{array}$ & $\mid \begin{array}{l}120^{\circ} \text { E.M.T } \\
120^{\circ} \text { E.M.T } \\
105^{\circ} \text { E.M.T } \\
105^{\circ} \text { E.M.T }\end{array}$ & $\left\{\begin{array}{l}3(6,14,21) \\
3(6,14,21) \\
8(3,6,9,12, \\
14,18,21,24) \\
24(1-24)\end{array}\right.$ \\
\hline $1954-1956.6$ & & $33^{\circ} 05^{\prime}$ & $107^{\circ} 10^{\prime}$ & $(511.4)$ & $105^{\circ}$ E.M.I & $24(1-24)$ \\
\hline $1957.1-5$ & & $33^{\circ} \mathrm{Co} 0^{\circ}$ & $1207^{\circ} 16^{\prime}$ & $\begin{array}{c}684.0 \\
(684.8)\end{array}$ & $\begin{array}{c}(\text { Beijing } \\
\text { t地) }\end{array}$ & $4(2,8,14,20)$ \\
\hline $1957.6-1960.7$ & & $33^{\circ} 00^{\circ}$ & $107^{\circ} 16^{\prime}$ & $\begin{array}{l}508.3 \\
(509.1)\end{array}$ & Local time & $4(1,7,23,19)$ \\
\hline $1960.8-1962$ & & $33^{\circ} 00^{\circ}$ & $107^{\circ} 16^{\circ}$ & $\begin{array}{r}684.0 \\
(509.1)\end{array}$ & (Beijing & $4(2,8,14,20)$ \\
\hline $1963-1979$ & & $33^{\circ} 04^{\prime}$ & $107^{\circ} 12^{\prime}$ & $\begin{array}{c}508.3 \\
(509.1)\end{array}$ & (Beijing & $4(2,8,14,20)$ \\
\hline $1980-1983$ & & $33^{\circ} 04^{\circ}$ & $107^{\circ} 12$ & $\mid \begin{array}{c}508.4 \\
(509.1)\end{array}$ & $\begin{array}{c}(B \theta i j \operatorname{ling} \\
\operatorname{tim\theta })\end{array}$ & $4(2,8,14,20)$ \\
\hline
\end{tabular}

C. Number of Observations Used for Calculating the Dally Mean

\begin{tabular}{|c|c|c|c|}
\hline Mear times & $\left|\begin{array}{c}\text { Mean pressure } \\
\text { (period) }\end{array}\right|$ & $\begin{array}{l}\text { Temperature } \\
\text { (period) }\end{array}$ & $\mid \begin{array}{c}\text { Relative humidity } \\
\text { (per1od) }\end{array}$ \\
\hline $\begin{array}{l}3(6,14,21) \\
8(3,6,9,12 \\
14,18,21,24)\end{array}$ & $1951-1952.1$ & $\begin{array}{l}1935-1950 \\
1951-1952.1\end{array}$ & $\begin{array}{l}1935.6-1945 \\
1948.10-1949.8 \\
1951.1\end{array}$ \\
\hline $\begin{array}{l}24(1-24) \\
4(1,7,13,19) \\
4(2,8,14,20) \\
4(2,8,14,20)\end{array}$ & $\begin{array}{l}1952.2-1953 \\
1954-1960.7 \\
1957.1-5 \\
1960.8-1983\end{array}$ & $\begin{array}{l}1952.2-1953 \\
1954-1960.7 \\
1957.1-5 \\
: 960.8-1983\end{array}$ & $\begin{array}{l}1951.2-1954 \\
1954-1960.7 \\
1957.1-5 \\
1960.8-1983\end{array}$ \\
\hline
\end{tabular}

D. Remarks:

1. Date divided time: 24 105'E sean time during 1951-1953

19 local time during $1954-1960.7$

20 Beijing time since 1960.8 
\$o. $36 \quad \$ 7461$ Y: Chang

A. Main Data Sources

$\begin{array}{ll}\text { 2. } 2882.7-1950 & (93) \\ \text { 2. } 1928-1936 \text { (pressure, humidity, w1nds, cloud amount) } & (15) \\ \text { 3. } 1951-1980 & (94) \\ \text { 4. } 1981-1983 & (13) \\ \text { 5. } 1951-1953 & (12)\end{array}$

3. Location of Station, Iime Standard and Times of Observacions

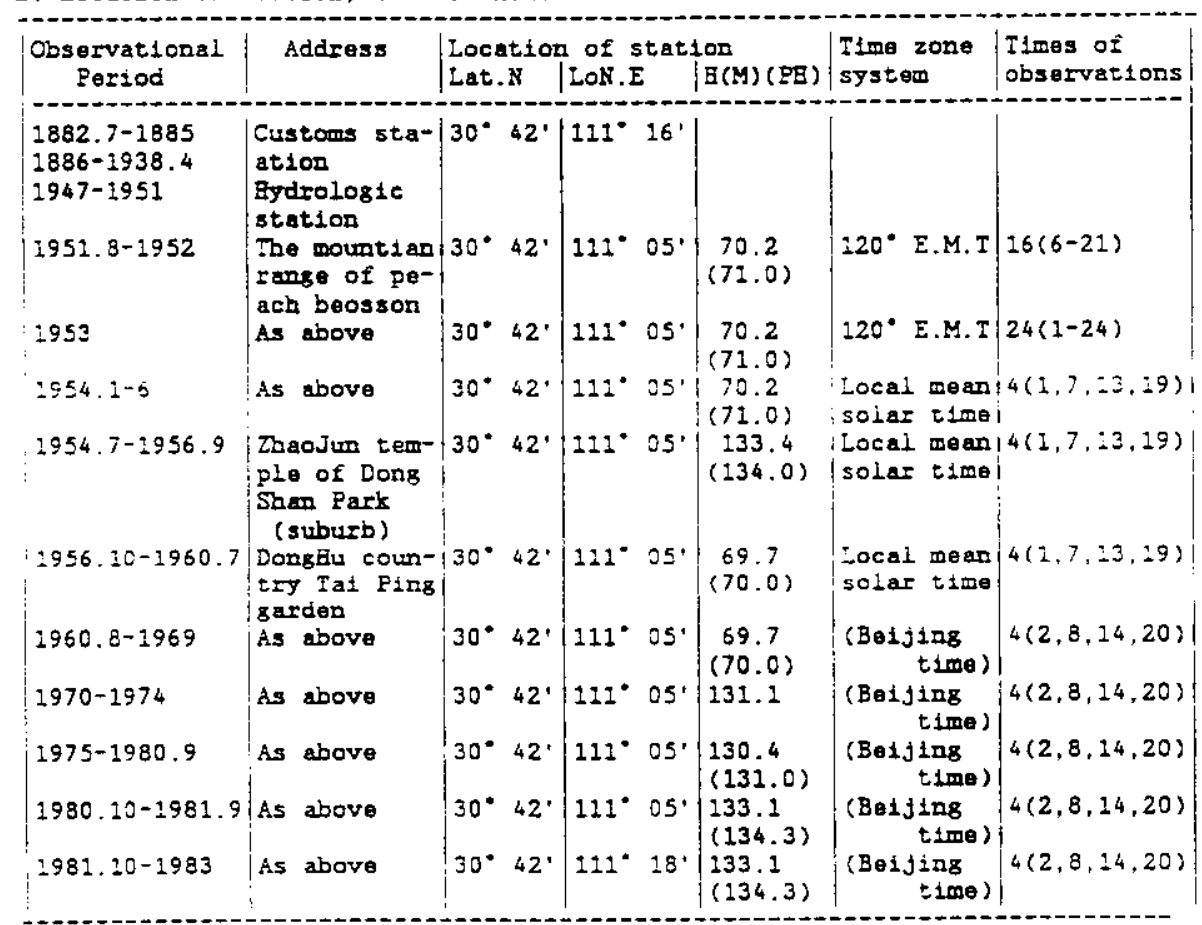

c. Number of Observations Used for Calculating the Daily Mean

\begin{tabular}{|c|c|c|c|c|}
\hline Mean times & $\begin{array}{l}\text { i Mean prossurei } \\
\text { (pariod) }\end{array}$ & $\begin{array}{c}\text { Tedperature } \\
\text { (period) }\end{array}$ & $\mid \begin{array}{c}\text { Relative humidity } \\
\text { (period) }\end{array}$ & $\begin{array}{l}\text { Wind } \\
\text { (period) }\end{array}$ \\
\hline 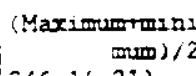 & & $1924-1933$ & & \\
\hline $\begin{array}{l}3(6,14,21) \\
24(1-24) \\
4(1,7,12,19) \\
4(2,8,14,20)\end{array}$ & $\begin{array}{r}1951.8-1953 \\
1954-1960.7 \\
2960.8-1983\end{array}$ & $\begin{array}{l}1934-1938 \\
1951.8-1953 \\
1954-1960.7 \\
1960.8-1983\end{array}$ & $\begin{array}{l}1951.8-1953 \\
1954-1960.7 \\
2960.8-1983\end{array}$ & $\begin{array}{l}1951.8-1953 \\
1954-1960.7 \\
1960.8-1983\end{array}$ \\
\hline
\end{tabular}

כ. Remarks :

$\therefore$ Pate divided time: Not clear before 195?

$21120^{\circ}$ E mean time during $1951-1952$
$24120^{\circ}$ mean time during 1953
19 local mean soiar time (L.M.S.I.) during $1954-1950.7$
20 Beijing time since 1960.8 
No. $37 \quad 57494$ Wh Bas

A. Main Data Sources
1. $1880-1950$
(95)
2. $1951-1980$
(96)
3. $1981-1983$
(13)
4. $1930-1936$ (cloud amoune)
(15)

B. Location of Station. Time Standard and Tlmes of Observations.

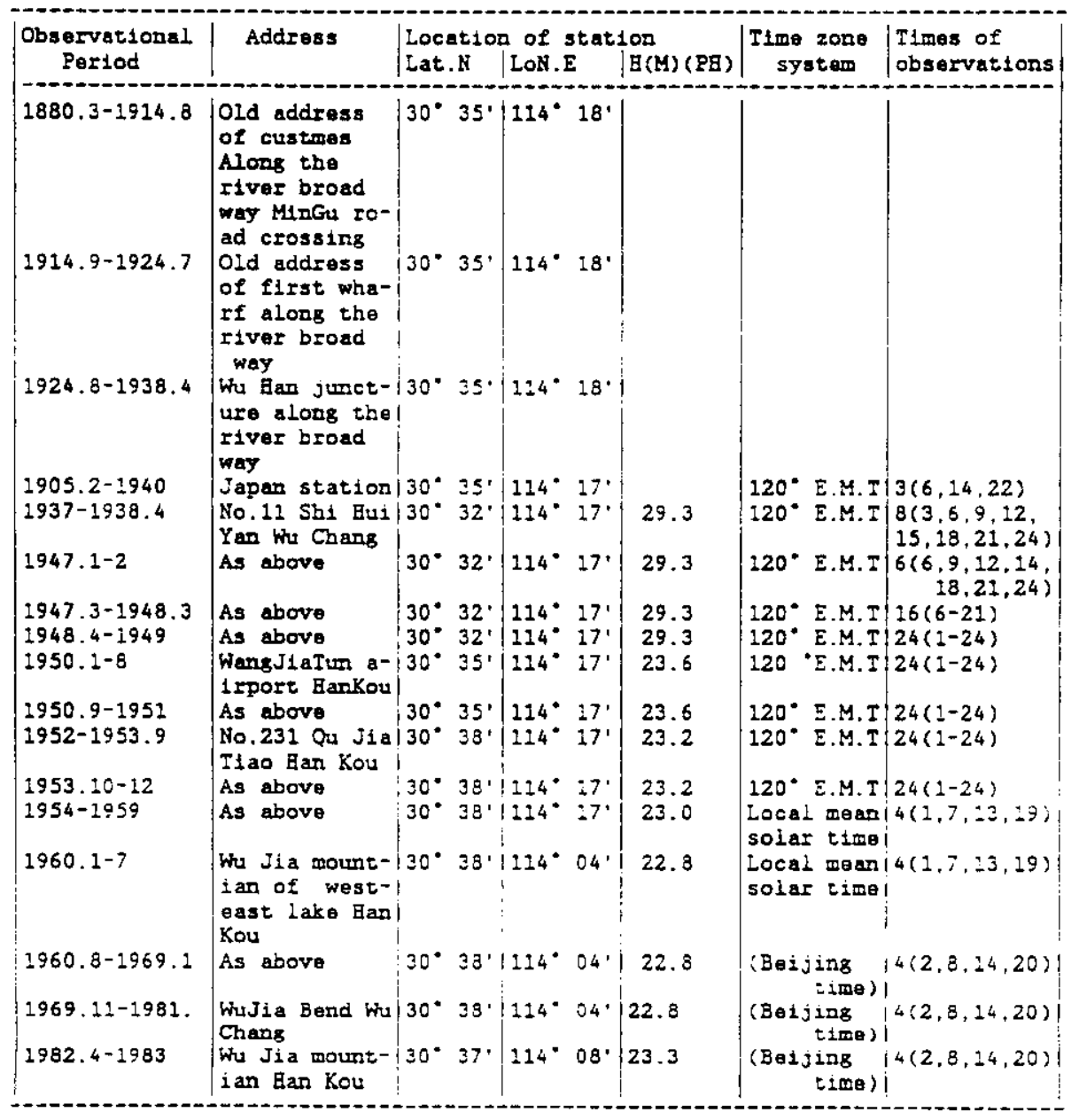




\section{B-42}

Ho. 3757494 the Ean (cont.)

c. Number of Observacions Used for Calculating the Daily Mean

\begin{tabular}{|l|l|l|l|l|}
\hline Mean times & $\begin{array}{l}\text { Mean pressure } \\
\text { (Period) }\end{array}$ & $\begin{array}{l}\text { Temperature } \\
\text { (Period) }\end{array}$ & $\begin{array}{l}\text { Relative } \\
\text { humidity } \\
\text { (Per10d) }\end{array}$ & Wind \\
(Perlod)
\end{tabular}

\section{Remarks :}

$\therefore$ Date divided time: Not clear durins 1880-1886.1

$$
\begin{aligned}
21 & \text { clock during } 1886.2-1887.3 .6 \\
9 & \text { clock during } 1887.4-1887.5,7-1935.6 \\
6 & \text { clock during } 1935.7-1938.4 \\
21 & \text { clock during } 1947-1949 \\
24 & \text { clock durins } 1950-1953 \\
19 & \text { clock during } 1954-1960.7 \\
20 & \text { clock since } 1960.6
\end{aligned}
$$

2. The procipitation date was taken form customs station during 1880-1949. 
No. 3857516 ChongQ1ng ShaPtngBa

A. Matn Data Sources

$\begin{array}{lr}\text { 1. } 1891-1950 & (97) \\ \text { 2. } 1928-1936 & (15) \\ \text { 3. } 1951-1980 & (98) \\ \text { 4. } 1981-1983 & (13) \\ \text { 5. } 1951-1960 \text { (dominant winds) } & (99) \\ \text { 6. } 1961-1980 \text { (dominant winds) } & (156)\end{array}$

B. Location of Station, Time Standard and Ilmes of Observations.

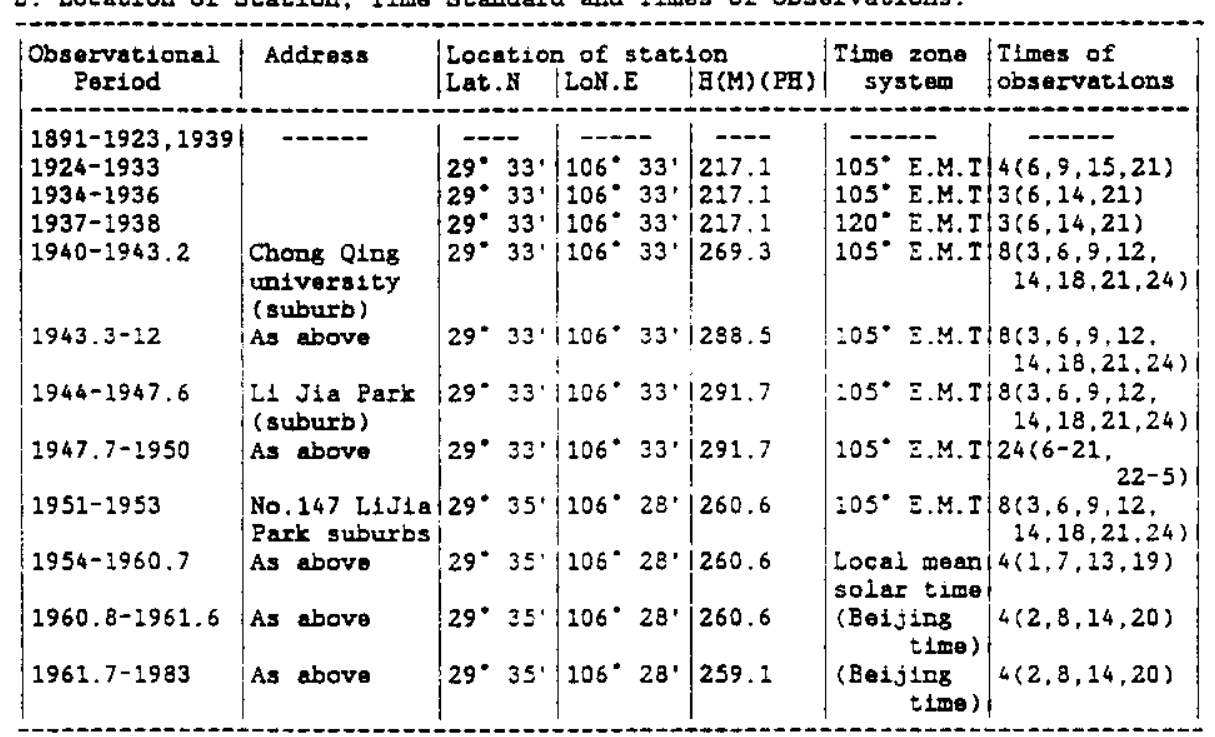

c. Number of Observations Used for Caleulating the Datly Mean

\begin{tabular}{|c|c|c|c|}
\hline Mean rimes & $\begin{array}{c}\text { Mean pressure } \\
\text { (Pertod) }\end{array}$ & $\mid \begin{array}{r}\text { Iemperature } \\
\text { (Period) }\end{array}$ & $\begin{array}{l}\text { Relative } \\
\text { humidity } \\
\text { (Pertod) }\end{array}$ \\
\hline $\begin{array}{r}(\operatorname{Max} 2 \operatorname{mog} \ln 1)_{1} \\
\operatorname{mum}) / 2\end{array}$ & - - & $1924-1928$ & $\cdots$ \\
\hline $3(6,14,21)$ & $\begin{array}{l}1934-1938 \\
1940-1947\end{array}$ & $\begin{array}{l}1934-1938 \\
1940-1947\end{array}$ & $\begin{array}{l}1934-1938 \\
1940-1947\end{array}$ \\
\hline $\begin{array}{l}3(6,15,21) \\
4(6,9,25,21)\end{array}$ & -..-- & $1929-1933$ & $1929-1933$ \\
\hline $\begin{array}{l}24(1-24) \\
8(3,6,9,12,14, \\
\quad 18,21,24)\end{array}$ & $\mid \begin{array}{l}1948-1950 \\
1951-1953\end{array}$ & $\begin{array}{l}1948-1950 \\
1951-1953\end{array}$ & $\begin{array}{l}1948-1950 \\
1951-1953\end{array}$ \\
\hline $\begin{array}{l}4(1,7,13,19) \\
4(2,8,14,20)\end{array}$ & $\begin{array}{l}1954-1960.7 \\
1960.8-1983\end{array}$ & $\begin{array}{l}1954-1960.7 \\
2960.8-1983\end{array}$ & $\mid \begin{array}{l}1954-1960.7 \\
1960.8-1983\end{array}$ \\
\hline
\end{tabular}

D. Remariks : 


\section{B-44}

No. 3957679 Charg Sha

A. Main Data Sources

$\begin{array}{lc}\text { 2. } 1909-1950 & (100)(3) \\ \text { 2. } 1932-1950 & (101) \\ \text { 3. } 1951-1980 & (102) \\ \text { 4. } \$ 981-1983 & (13) \\ \text { 5. } 1928-1936 & (15)\end{array}$

B. Location of Station, Iime Standard and Itmes of Observations.

\begin{tabular}{|c|c|c|c|c|c|c|}
\hline $\begin{array}{c}\text { Observartional } \\
\text { Period }\end{array}$ & Address & $\begin{array}{l}\text { Locatiod } \\
\text { Lat. N }\end{array}$ & $\begin{array}{l}\text { D of stati } \\
\text { |LON.E }\end{array}$ & $\mid$ & $\begin{array}{c}\text { Time } 20 \pi \theta \\
\text { systam }\end{array}$ & $\begin{array}{l}\text { Times of } \\
\text { observations }\end{array}$ \\
\hline 2909-1938 & $\begin{array}{l}\text { Metoorologi- } \\
\text { cal station } \\
\text { cusmos }\end{array}$ & $28^{\circ} 12^{\prime}$ & $\left|112^{\circ} 47^{\prime}\right|$ & 60.0 & & \\
\hline $1932.8-1938.7$ & IfanXin Park & $28^{\circ} 13^{\prime} \mid$ & $112^{\circ} 46^{\prime}$ & 90.0 & $120^{\circ}$ E.M.T & $\begin{array}{l}8(3,6,9,12, \\
15,18,21,24)\end{array}$ \\
\hline $1938.8-1948.1$ & $\begin{array}{l}\text { Dons Tang of } \\
\text { Southern mo- } \\
\text { uth out }\end{array}$ & $28^{\circ} 13^{\circ}$ & $112^{\circ} 46^{\prime}$ & 60.0 & $120^{\circ}$ E.M.T & $\begin{array}{r}8(3,6,9,12 \\
15,18,21,24)\end{array}$ \\
\hline $1948.2-12$ & $\begin{array}{l}\text { The grave of } \\
\text { a revolutio- } \\
\text { nnary martyr } \\
\text { Xians Oing } \\
\text { road }\end{array}$ & $28^{\circ} 13^{\circ}$ & $112^{\circ} 46^{\circ}$ & 55.0 & $220^{\circ}$ E.M.T & $\begin{array}{l}8(3,6,9,12, \\
15,18,21,24)\end{array}$ \\
\hline$\therefore 949-1950.7$ & $\begin{array}{l}\text { Army road } \\
\text { side }\end{array}$ & $28^{\circ} 15^{\prime}$ & $112^{\circ} \leq 0^{\circ}$ & 60.0 & $20^{\circ}$ E.M.T & $\begin{array}{r}8(3,6,9,15 \\
18,21,24)\end{array}$ \\
\hline $1950.8-1951$ & $\begin{array}{l}\text { No. } 94 \text { Army } \\
\text { road side }\end{array}$ & $28^{\circ} 15^{\prime}$ & $112^{\circ} 50^{\circ}$ & 60.0 & $120^{\circ}$ E.M.T & $24(1-24)$ \\
\hline 1952.1 & As above & $28^{*} 15^{\circ}$ & $112^{\circ} 50^{\circ}$ & 60.0 & $\begin{array}{l}\text { (Beijing } \\
\text { tIme)! }\end{array}$ & $24(1-24)$ \\
\hline 1952.2 & As above & $28^{\circ} 15^{\prime}$ & $112^{\circ} 50^{\circ}$ & 60.0 & 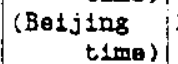 & $24(1-24)$ \\
\hline $1952.3-5$ & As above & $28^{*} 15^{\prime}$ & $112^{\circ} 50^{\circ}$ & 60.0 & $\begin{array}{c}(B e i j \pm n g \\
t \operatorname{Im\theta })\end{array}$ & $24(1-24)$ \\
\hline $1952.6-1953$ & As above & $28^{\circ} 15^{\circ}$ & $112^{\circ} 50^{\circ}$ & 60.0 & $\begin{array}{c}(B \theta \pm j \ln g \\
t \pm \theta(\theta)\end{array}$ & $24(1-24)$ \\
\hline 1954.1 & $\begin{array}{l}\text { Yang Jia mo- } \\
\text { untian range } \\
\text { of Xiao Guad } \\
\text { gate out }\end{array}$ & $28^{\circ} 15^{\prime}$ & $112^{\circ} \leq 0^{\circ}$ & 48.0 & Local time & $4(1,7,13,19)$ \\
\hline $\begin{array}{l}1954.2-1955.9 \\
1955.10-1956.1 \\
1956.11-1960.7\end{array}$ & $\begin{array}{l}\text { As above } \\
\text { |As above } \\
\text { i NiuJiaorang }\end{array}$ & $\begin{array}{l}28^{\circ}=15^{\prime} \\
28^{\circ} \\
28^{\circ} \\
25^{\circ}\end{array}$ & 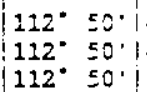 & $\begin{array}{l}148.6 \\
148.0 \\
81.3\end{array}$ & $\begin{array}{l}\text { Local timo } \\
\text { Local time } \\
\text { Local time }\end{array}$ & $\begin{array}{l}4(1,7,23,19) \\
4(1,7,13,19) \\
4(1,7,23,19)\end{array}$ \\
\hline & $\begin{array}{l}\text { of rainflow- } \\
\text { ef parvilie- } \\
\text { en south ga- } \\
\text { ta out }\end{array}$ & & & & & \\
\hline$: 960.8-1963$ & As above & $28^{\circ}: 5^{\circ}$ & $112^{\circ} \leq 0^{\circ}$ & 81.3 & (Seijing & $4(2,8,14,20)$ \\
\hline $1964-1983$ & $\begin{array}{l}\text { FuYuan } Z_{i} \text { of } \\
\text { east county } \\
\text { mountian ra- } \\
\text { nge agricul- } \\
\text { tural fleld }\end{array}$ & $28^{\circ} 12^{\prime}$ & $113^{\circ} 05^{\prime}$ & 44.9 & (Be1jing & $4(2,8,14,20)$ \\
\hline
\end{tabular}

c. Number of Cbservations Used for Calculating the Daily Mean

\begin{tabular}{|c|c|c|c|c|}
\hline Mean Eimes & $\begin{array}{l}\text { Yean pressure } \\
\text { (Period) }\end{array}$ & $\begin{array}{l}\text { I emperature } \\
\text { (Period) }\end{array}$ & $\begin{array}{l}\text { Relative } \\
\text { ihumidity } \\
\text { (Period) }\end{array}$ & $\begin{array}{l}\text { hind } \\
\text { (Perlod) }\end{array}$ \\
\hline $\begin{array}{r}\text { (Maximumraini } \\
\operatorname{mum}) / 2\end{array}$ & $---\cdots$ & $1924-1928$ & $\cdots-$ & \\
\hline $\begin{array}{r}8(3,6,9,12,25 \\
: 3,21,24)\end{array}$ & $: 932.8-1950.7$ & $2920-1933$ & $\begin{array}{l}932.8-1938.7 \\
1946.4-1949.3 \\
1946.10-1950.7\end{array}$ & \\
\hline $\begin{array}{l}3(6,14,21) \\
24(1-24) \\
4(1,7,13,19) \\
4(2,8,14,20)\end{array}$ & $\begin{array}{l}1950.8-1953 \\
1954-1960.7 \\
960.8-1983\end{array}$ & $\begin{array}{l}1933-1950 \\
1951-1953 \\
1954-1960.7 \\
1960.8-1983\end{array}$ & $\begin{array}{l}1950.8-1953 \\
1954-1960.7 \\
1960.8-1983\end{array}$ & $\begin{array}{l}1950.8-1953 \\
1954-1960.7 \\
1960.8-1983\end{array}$ \\
\hline
\end{tabular}


No. 3957679 Chang Sha (cont.)

D. Remarix:

i. Before 1948.2, pressure was always corrected to 60 meters elevation.

2. During 1951-1983, pressure was reduced by 3.5 mb to adjust for the lower station elevation. 
¿. Matn Data Sources
1. $1938-1949$
2. $1952-1980$
(3)(2)(4)
(103)
3. 1981-1983
(13)(104)

E. Location of Station, Time Standard and Times of Observations.

\begin{tabular}{|c|c|c|c|c|c|c|}
\hline $\begin{array}{l}\text { Observational } \\
\text { Pertod }\end{array}$ & Address & $\begin{array}{l}\text { Locat1or } \\
\text { Lat. A }\end{array}$ & $\begin{array}{l}\text { nof stat. } \\
\text { LoN.E }\end{array}$ & $|\mathrm{E}(\mathrm{M})(\mathrm{PB})|$ & $\mid \begin{array}{c}\text { Time zone } \\
\text { system }\end{array}$ & $\begin{array}{l}\text { Ttmes of } \\
\text { observations }\end{array}$ \\
\hline $1938.6-1948.3$ & $\begin{array}{l}\text { GuJia garden } \\
\text { of west gate } \\
\text { out }\end{array}$ & $27^{\circ} 28^{\prime} \mid$ & $109^{\circ} 54^{\prime}$ & 251.9 & $120^{\circ}$ E.M.I & $3(6,14,21)$ \\
\hline $1948.4-1949.3$ & $\begin{array}{l}\text { EouShalong of } \\
\text { Ifver west }\end{array}$ & $27^{\circ} 27^{\prime}$ & $109^{\circ} 38^{\prime}$ & ----- & $120^{\circ}$ E.M.I & $\{3(6,14,21\}$ \\
\hline $\begin{array}{l}1949.4-1950.12 \\
1951-1953\end{array}$ & $\begin{array}{l}\text { 2hongSha Park } \\
\text { North of air- } \\
\text { port East ga- } \\
\text { to out }\end{array}$ & $\left|\begin{array}{ll}27^{\circ} & 27^{\circ} \\
27^{\circ} & 27^{\circ}\end{array}\right|$ & $\begin{array}{l}109^{\circ} 38^{\circ} \\
109^{\circ} 38^{\circ}\end{array}$ & 266.5 & $\begin{array}{l}120^{\circ} \text { E.M.T } \\
120^{\circ} \text { E.M.T }\end{array}$ & $\mid \begin{array}{l}3(6,14,21) \\
8(3,6,9,12, \\
14,18,21,24)\end{array}$ \\
\hline $1954-1955.10$ & $\begin{array}{l}\text { North of atr- } \\
\text { port East } 8 \mathrm{a}- \\
\text { to out }\end{array}$ & $27^{\circ} 27^{\circ}$ & $109^{\circ} 38^{\circ}$ & 266.5 & Local time & $|4(1,7,23,19)|$ \\
\hline $\begin{array}{l}955.11-1960 \\
: 961-1971\end{array}$ & $\begin{array}{l}\text { As above } \\
\text { North of als- } \\
\text { port East ga- } \\
\text { te out }\end{array}$ & $\begin{cases}27^{\circ} & 27^{\prime} \\
27^{\circ} & 27^{\prime}\end{cases}$ & $\begin{array}{l}109^{\circ} 38^{\prime} \\
109^{\circ} \\
38^{\prime}\end{array}$ & $\begin{array}{l}266.5 \\
266.5\end{array}$ & $\begin{array}{c}\text { Local ti=e } \\
\text { (Boijing } \\
\text { timo) }\end{array}$ & $\begin{array}{l}14(1,7,23,19) \\
4(2,8,14,20) !\end{array}$ \\
\hline$: 972-1973.11$ & $\left|\begin{array}{l}\text { Long Jing Po } \\
\text { of North gate } \\
\text { out(htil top) }\end{array}\right|$ & $27^{\circ} 27^{\prime}$ & $109^{\circ} 38^{\prime}$ & 271.9 & $\left(\begin{array}{c}(B \in 1 j i n g \\
t i m \theta)\end{array}\right.$ & $i 4(2,8,14,20)$ \\
\hline $1973.12-1976$ & As above & $27^{\circ} 27^{\prime} \mid$ & $109^{\circ} 38^{\circ}$ & 272.2 & $\left(\begin{array}{c}\text { (Beijing } \\
\text { time })\end{array}\right.$ & $4(2,8,14,20)$ \\
\hline $1977-1983$ & As above & $27^{\circ} 27^{\prime}$ & $109^{\circ} 41^{\prime}$ & 271.9 & $\begin{array}{c}\text { (Beijing } \\
\text { time })\end{array}$ & $4(2,8,14,20)$ \\
\hline
\end{tabular}

C. Number of Observations Used for Calculating the Daily Mean

\begin{tabular}{|l|c|l|l|}
\hline Mean Times & $\begin{array}{c}\text { Mean pressure } \\
\text { (Period) }\end{array}$ & $\begin{array}{l}\text { Temperature } \\
\text { (Period) }\end{array}$ & $\begin{array}{l}\text { Relative } \\
\text { buraidity } \\
\text { (Period) }\end{array}$ \\
\hline $3(6,14,21)$ & $\cdots$ & $1938-1949$ & $1938.6-1949.4$ \\
$24(1-24)$ & & & $1950.6-1950.12$ \\
$4(4,7,13,19)$ & $1951-1953$ & $1954-1953$ & $1951-1953$ \\
$4(2.8,14,20)$ & $2961-1983$ & $1954-1960$ & $1954-1960$ \\
\hline
\end{tabular}

2. Remariks: 
A. Main Data Sources
1. $1920-1950$
2. $1951-1960$
(105)
3. $1961-1970$
(12)
4. $1971-1980$
(106)
5. 1981-1983
6. 1961-1970
(13)
7. $1933-1936$
(15)

B. Location of Station, Time Standard and Times of Observations.

\begin{tabular}{|c|c|c|c|c|c|c|}
\hline $\begin{array}{l}\text { Observational } \\
\text { Period }\end{array}$ & Address & $\begin{array}{l}\text { Locatior } \\
\text { Lat. N }\end{array}$ & $\begin{array}{l}\text { n of stat } \\
\text { iLoN.E }\end{array}$ & $\begin{array}{l}100 \\
\mid \mathrm{E}(\mathrm{M}) \text { (PE) }\end{array}$ & $\begin{array}{c}\text { Time zone } \\
\text { systom }\end{array}$ & $\begin{array}{l}\text { Tlemes of } \\
\text { observat } 10 \text { sons }\end{array}$ \\
\hline $\begin{array}{l}1920-1935 \\
1935.11\end{array}$ & $\begin{array}{l}\text { Cheng Lans } \\
\text { threo pleces } \\
\text { of farmland } \\
\text { (sururb) }\end{array}$ & $\left|\begin{array}{ll}26^{\circ} & 38^{\prime} \\
26^{\circ} & 35^{\prime}\end{array}\right|$ & $\mid \begin{array}{l}106^{\circ} 40^{\prime} \\
106^{\circ} 40^{\circ}\end{array}$ & $\mid \begin{array}{l}1075.0 \\
1075.0\end{array}$ & $120^{\circ}$ E.M.T & $6(6,9,12,14$, \\
\hline $1935.12-1936$ & As above & $26^{\circ} 35^{\circ}$ & $106^{\circ} 43^{\prime}$ & 1075.0 & $120^{\circ}$ E.M.I & $\begin{array}{l}8(3,6,9,12, \\
14,18,21,24)\end{array}$ \\
\hline $1937-1938$ & $\begin{array}{l}\text { Mulberry fi- } \\
\text { eid LiuGuans } \\
\text { gate out } \\
\text { (suburb) }\end{array}$ & $\begin{array}{lll}26^{\circ} & 35 & \\
3 & & \end{array}$ & $1106^{\circ} 43^{\prime}$ & $: 075.0$ & $220^{\circ}$ E.M.TI & $24(1-24)$ \\
\hline $\begin{array}{l}1939-1946.6 \\
1946.7-1953.8\end{array}$ & $\begin{array}{l}\text { As above } \\
\text { No: } 117 \mathrm{X} 1 \mathrm{n}^{-} \\
\text {Bua road } \\
\text { (10 city) }\end{array}$ & $\left|\begin{array}{ll|}26^{\circ} & 35^{\prime} \\
26^{\circ} & 35^{\prime}\end{array}\right|$ & $\begin{array}{l}106^{\circ} 43^{\prime} \\
106^{\circ} 43^{\prime}\end{array}$ & $\begin{array}{l}1057.4 \\
1057.4\end{array}$ & $\begin{array}{l}105^{\circ} \text { E.M.T } \\
105^{\circ} \text { E.M.T }\end{array}$ & $\begin{array}{l}24(1-24) \\
24(1-24)\end{array}$ \\
\hline $\begin{array}{l}1953.9-12 \\
1954-1960.7\end{array}$ & $\begin{array}{l}\text { As above } \\
\text { No: } 56 \text { Cuthux } \\
\text { ailey } \\
\text { (in city) }\end{array}$ & $\mid \begin{array}{ll}26^{\circ} & 34^{\prime} \\
26^{\circ} & 34^{\circ}\end{array}$ & $\begin{array}{l}106^{\circ} 42^{\prime} \\
106^{\circ} 42^{\prime}\end{array}$ & $\begin{array}{l}1071.0 \\
1071.2\end{array}$ & $\begin{array}{l}105^{\circ} \text { E.M.T. } \\
\text { Local time }\end{array}$ & $\left\{\begin{array}{l}24(1-24) \\
4(1,7,13,19)\end{array}\right.$ \\
\hline $1960.8-1965.3$ & As above & $26^{\circ} 34^{\prime}$ & $106^{\circ} 42^{\circ}$ & 1071.2 & $\begin{array}{c}\text { (Beijing } \\
\text { :ime) }\end{array}$ & $4(2,8,14,20)$ \\
\hline $1965.4-1983$ & As above & $26^{\circ} 35^{\prime}$ & $106^{\circ} 43^{\circ}$ & 1071.2 & $\begin{array}{c}\text { (Beijing } \\
t \pm \theta \theta\end{array}$ & $4(2,8,14,20)$ \\
\hline
\end{tabular}

C. Number of Observations Used for Calculating the Daily Nean

\begin{tabular}{|c|c|c|c|}
\hline Mean E2mas & $\begin{array}{c}\text { Mean pressure } \\
\text { (Period) }\end{array}$ & $\begin{array}{l}\text { Temperature } \\
\text { (Ferlod) }\end{array}$ & $\begin{array}{l}\text { Relative } \\
\text { humidity } \\
\text { (Period) }\end{array}$ \\
\hline $366,14,21)$ & $\begin{array}{l}1935.12-\vdots 2 \\
1936\end{array}$ & $\begin{array}{l}1920-1935 \\
: 936.1938 .5-1940\end{array}$ & $\begin{array}{l}1935.11-1936 \\
1938.5-1940 \\
1944.2-1945.4\end{array}$ \\
\hline 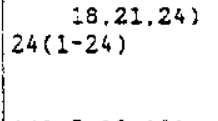 & $1937-1953$ & $\begin{array}{l}1937-1938.4 \\
1941-19 \leq 3\end{array}$ & $\begin{array}{l}1937-1938.4 \\
1941-1944.1 \\
1945.5-1953\end{array}$ \\
\hline $\begin{array}{l}4(1,7,23,19) \\
4(2,8,14,20)\end{array}$ & $\begin{array}{l}1954-1960.7 \\
1960.8-1983\end{array}$ & $\begin{array}{l}-954-1960.7 \\
1960.8-1983\end{array}$ & $\begin{array}{l}1954-1960.7 \\
1960.8-1983\end{array}$ \\
\hline
\end{tabular}

D. Remarks: 
A. Main Data Sources

$\begin{array}{lc}\text { i. } 1915-1950 & (3)(108) \\ \text { 2. } 1929-1936 & (15) \\ \text { 3. } 1951-1959 & (109) \\ \text { 4. } 1960-1980 & (110) \\ \text { 5. } 1981-1983 & (13) \\ \text { E. } 1926-1973 & (111)\end{array}$

3. Location of Station, Itme Standard and Times of Observations.

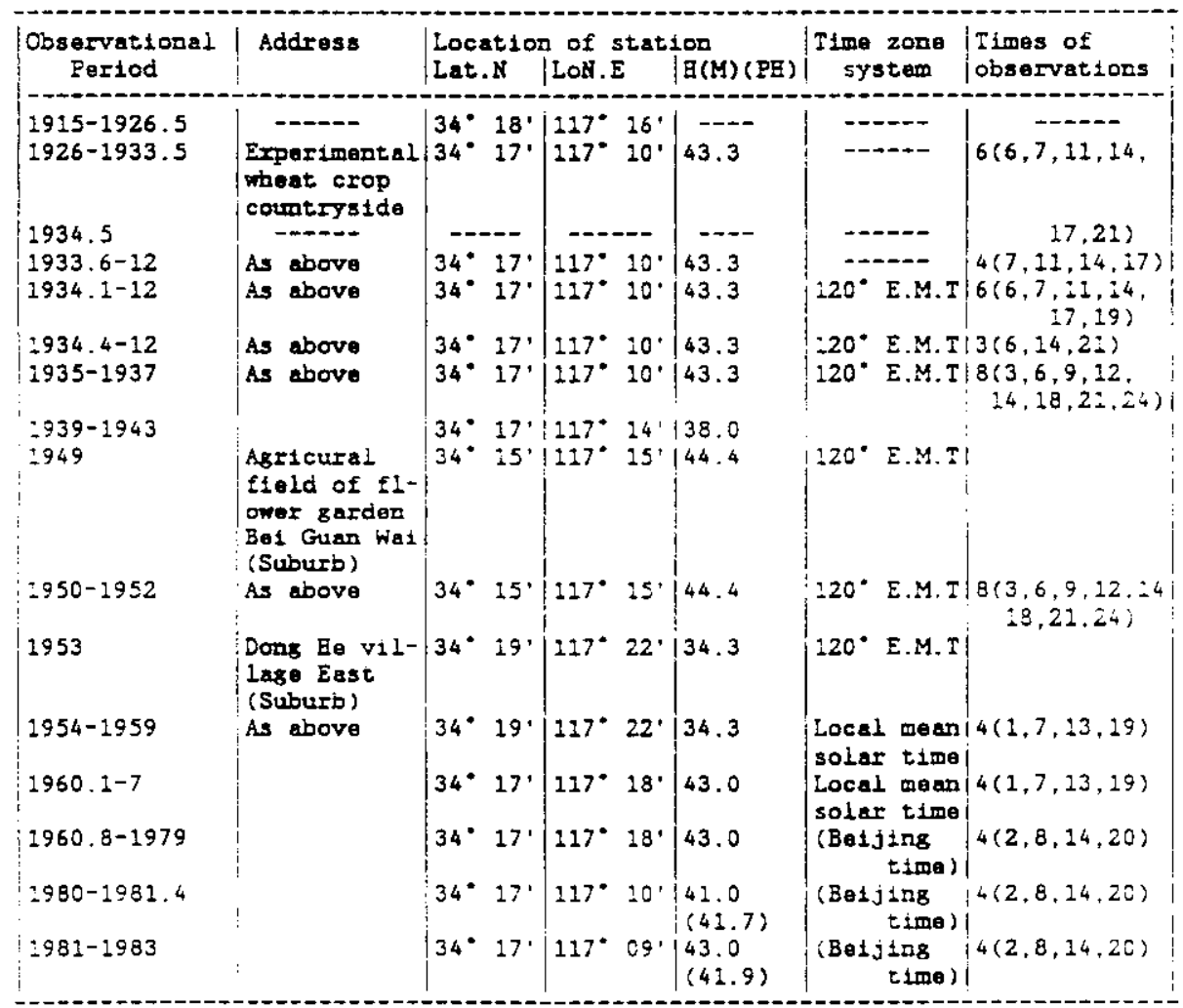

2. Viuber of Observations Used for Calcularing the Daily Mean

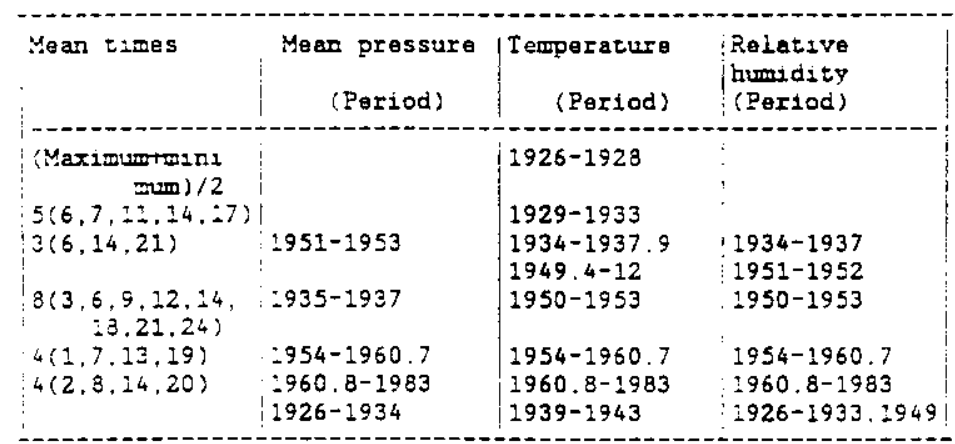

2. Eemarixs :

Oid name: Tong Sinan 
A. Main Data Sources

$\begin{array}{lr}\text { 1. } 1913-1950 \text { (precipitation) } & (3) \\ \text { 2. } 1928-1937 \text { (temperature) } & (111) \\ \text { 3. } 1950 \text { (humidity) } & (4) \\ \text { 4. } 1932-1950 & (5) \\ \text { 5. } 1951-1980 & \text { (112) } \\ \text { 6. } 1981-1983 & \text { (13) }\end{array}$

B. Location of Station. Ifme Stanciard and Times of Observations.

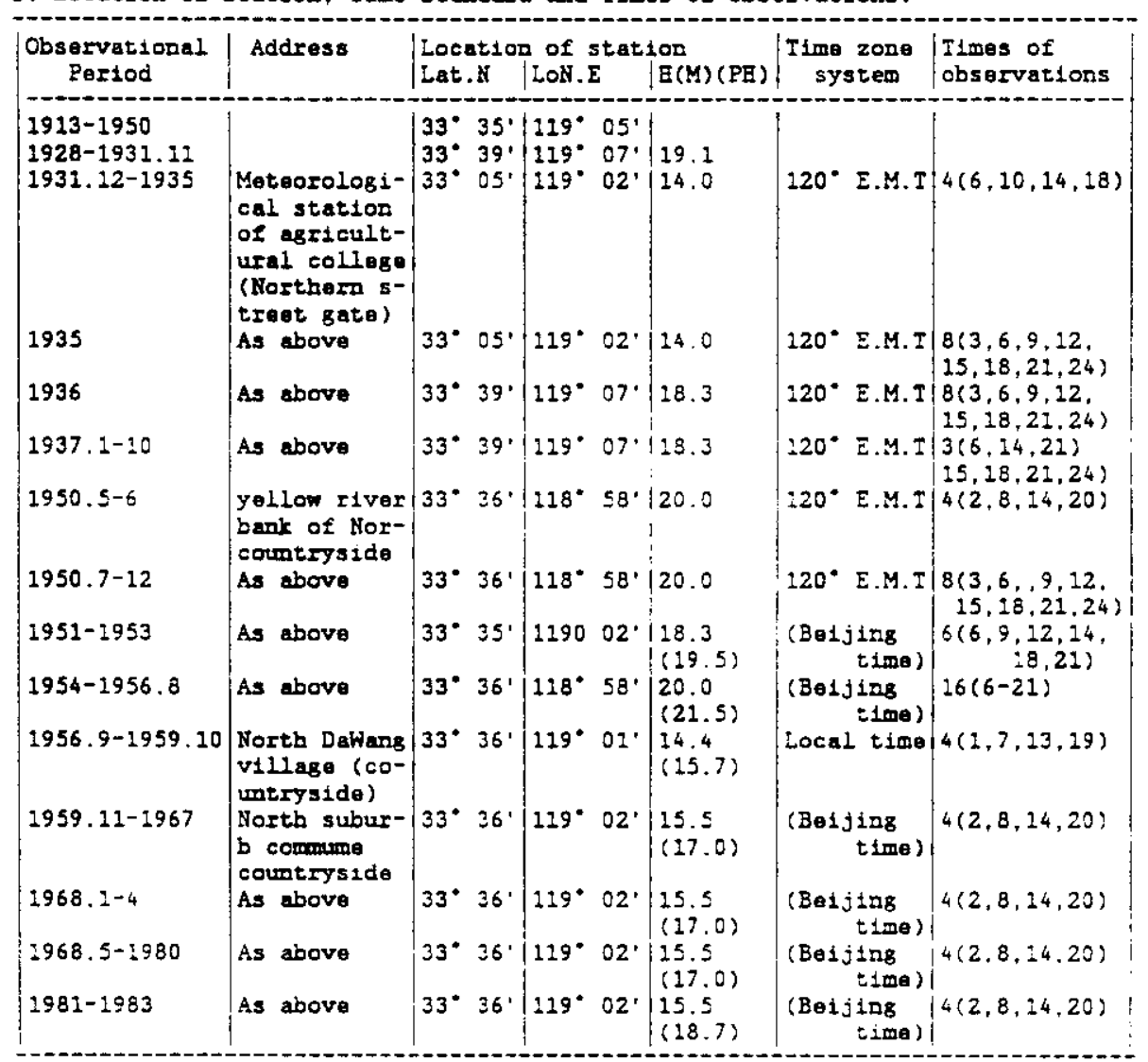

c. Yumber of Observations Used for Calculating the Daily Mean

\begin{tabular}{|c|c|c|c|}
\hline Mean times & $\begin{array}{c}\text { Mean pressure } \\
\text { (Period) }\end{array}$ & $\begin{array}{r}\text { Temperarura } \\
\text { (Perlod) }\end{array}$ & $\begin{array}{l}\text { Relative } \\
\text { humidity } \\
\text { (Period) }\end{array}$ \\
\hline $\begin{array}{l}4(6,10,14,18) \\
8(3,6,9,12,15 . \\
\quad 18,21,24) \\
3(6,14,21) \\
24(1-24) \\
4(1,7,13,19) \\
4(2,8,14,20)\end{array}$ & $\begin{array}{l}1950.7-1952 \\
1953 \\
1954-1960.7 \\
1960.8-1983\end{array}$ & $\begin{array}{l}1931.12-1935 \\
2935-1936 \\
1950.7-1952 \\
1937.1-10 \\
1953 \\
2954-1950.7 \\
: 960.8-1983\end{array}$ & $\begin{array}{l}1950.7-12 \\
1951-1952 \\
1953 \\
1950.5-6 \\
1954-1960.7 \\
1960.8-1.983\end{array}$ \\
\hline
\end{tabular}

D. Remarixs:

$\therefore$ This station actually moved just three times, in 1931.12. 1950.5. and 1956.9. ․though there were no station moves during $1954.1-2956.8$, a change of measurement tecnnique resuited is rew assignments of iongitude, Latitudo and elevacion. 


\section{B-50}

A. Main Data Sources

$\begin{array}{lr}\text { 2. } 1905-1950 & (113) \\ 1905-1970 & (114) \\ 1963-1972 & (111) \\ \text { 2. } 1971-1980 & (115) \\ \text { 3. } 1971-1980 & (159) \\ \text { 4. } 1908-1928 & (5) \\ \text { 5. } 1981-1983 & (13)\end{array}$

3. Location of Station, Tlme Standard and Times of Observations.

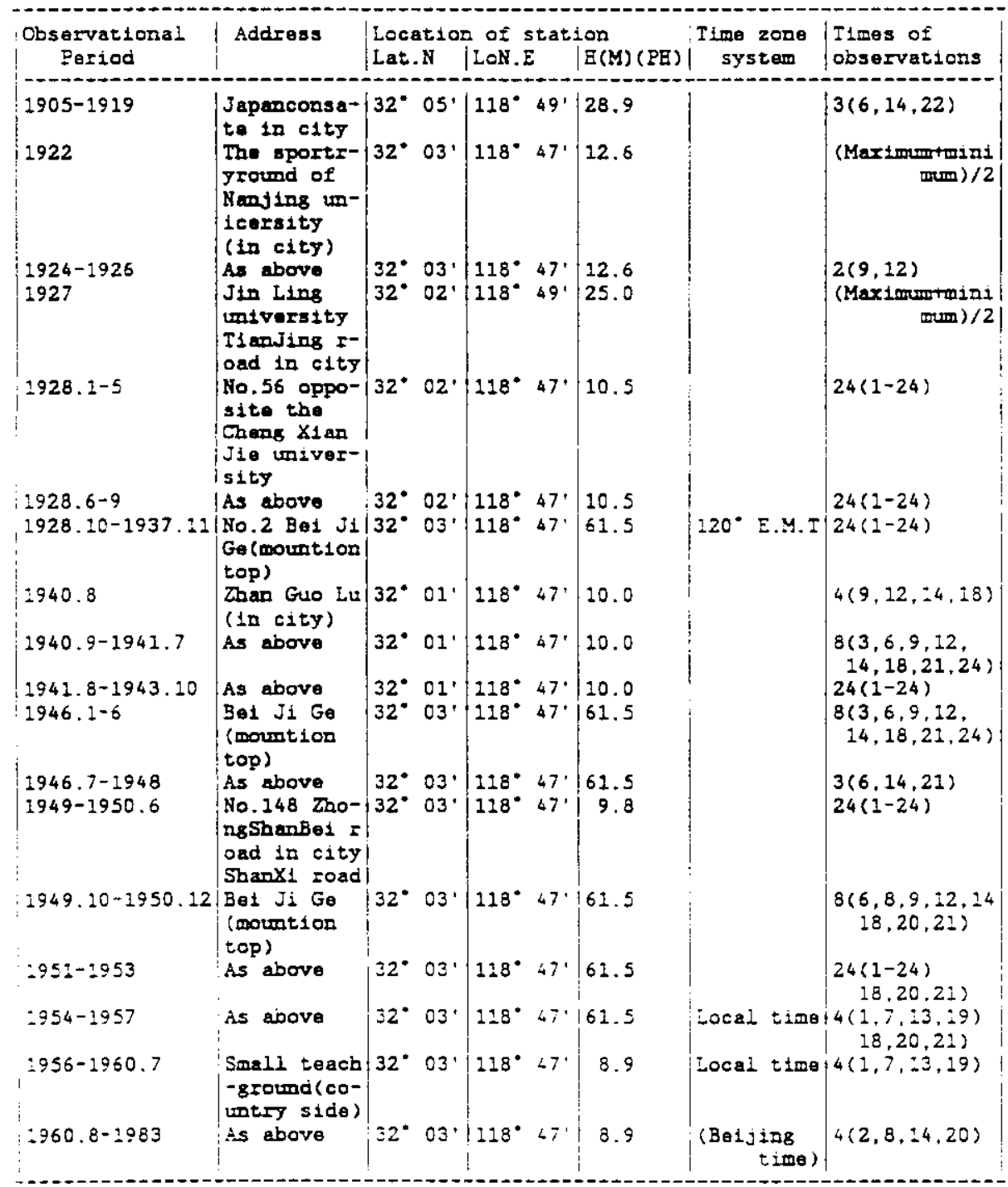


Yo. 4458238 Nan Jing (cont.)

C. Number of Observations tsed for Calculating the Daily Mean

\begin{tabular}{|c|c|c|c|c|c|}
\hline Mean times & $\begin{array}{c}\text { Mean pressure } \\
\text { (Period) }\end{array}$ & (Period) & $\begin{array}{l}\text { Relative } \\
\text { humidity } \\
\text { (Reriod) }\end{array}$ & $\begin{array}{l}\text { Wind } \\
\text { (Period) }\end{array}$ & $\begin{array}{l}\text { Cloud } \\
\text { (Period) }\end{array}$ \\
\hline 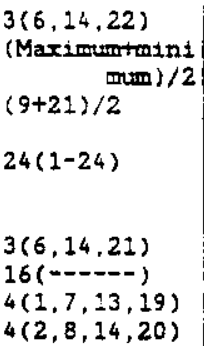 & $\begin{array}{l}1929-1937 \\
1949-1953 \\
1946-1948 \\
1954-1960.7 \\
1960.8-1983\end{array}$ & $\begin{array}{l}1905.1907-1919 \\
1921-1922 \\
1927 \\
1924-1926,1928 \\
1928-1940.8 \\
1929-1937 \\
1949-1953 \\
1946-1948 \\
1954-1960.7 \\
1960.8-1983\end{array}$ & $\begin{array}{l}1929-1937 \\
1949-1953 \\
1946-1948 \\
2954-1960.7 \\
1960.8-1983\end{array}$ & $\mid \begin{array}{l}1929-1937 \\
1948-1953 \\
1946-1947 \\
1954-1960.7 \\
1960.8-1983\end{array}$ & $\begin{array}{l}1948-1953 \\
1946-1947 \\
1954-1960.7 \\
1960.8-1983\end{array}$ \\
\hline
\end{tabular}

D. Remarixs : 


\section{B-52}

No. $45 \quad 58367$ Shanghas

A. Main Data Sources
$\therefore \quad 1873-1950$
$1873-1970$
$(116)(117)$
2. $1951-1980$
(118)
3. $1933-1936.11$
(15)

3. Location of Station, Time Standard and Times of Cbservations.

\begin{tabular}{|c|c|c|c|c|c|c|}
\hline $\begin{array}{l}\text { Observationai } \\
\text { Period }\end{array}$ & Address & $\begin{array}{l}\text { Location } \\
\text { Lat.N }\end{array}$ & $\begin{array}{l}\text { a of stati } \\
\text { LoN.E }\end{array}$ & $\begin{array}{l}\mathrm{i} O \mathrm{I} \\
\mathrm{E}(\mathrm{M})(\mathrm{PE})\end{array}$ & $\begin{array}{c}\text { T1se zone } \\
\text { system }\end{array}$ & $\begin{array}{l}\text { Times of } \\
\text { observations }\end{array}$ \\
\hline $\begin{array}{l}2873-1900 \\
1901-1955 \\
1956-1983\end{array}$ & $\begin{array}{l}X_{u} J i a \text { Bui } \\
X_{u} J i a \text { Bui } \\
\text { No.7 Longcao } \\
\text { soad (observ- } \\
\text { attonal fie } \\
\text { id-countrys- } \\
\text { ido) }\end{array}$ & $\left|\begin{array}{ll}31^{\circ} & 12 \\
31 & 12 \\
31 & 10 \\
& 10\end{array}\right|$ & $\left|\begin{array}{ll}121^{*} & 26 \\
121 & 26 \\
121 & 26 \\
26\end{array}\right|$ & $\begin{array}{l}7.3 \\
4.6 \\
4.5\end{array}$ & $\begin{array}{l}120^{\circ} \text { E.M.T } \\
120^{\circ} \text { E.M.T } \\
120^{\circ} \text { E.M.T }\end{array}$ & $\left\{\begin{array}{l}24(1-24) \\
24(1-24) \\
24(1-24)\end{array}\right.$ \\
\hline
\end{tabular}

C. Number of Observations Used for Calculating the Daily Mean

\begin{tabular}{|c|c|c|c|c|c|}
\hline Mean tires & $\begin{array}{c}\text { Mean pressura } \\
\text { (Zertod) }\end{array}$ & $\left|\begin{array}{c}\text { Temperature } \\
\text { (Period) }\end{array}\right|$ & $\begin{array}{l}\text { Relative } \\
\text { humidity } \\
\text { (Pertod) }\end{array}$ & $\begin{array}{l}\text { Wind } \\
\text { (Period) }\end{array}$ & $\begin{array}{l}\text { Cloud } \\
\text { (Fertod) }\end{array}$ \\
\hline 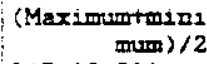 & & $1873-1874$ & & & \\
\hline $\begin{array}{l}3(7,12,21) \\
7(4,7,20,13, \\
\quad: 5,19,22)\end{array}$ & $\begin{array}{l}1873.1-1874.8 \\
1874.9-1875.1\end{array}$ & & $\begin{array}{l}1873-1874.8 \\
1874.9-1875.2 \\
1882.12-1883.1 \\
1884.1-2\end{array}$ & $\begin{array}{l}1973.1-1874.8 \\
: 874.9-1875.1\end{array}$ & $\begin{array}{l}1873.1-1874.8 \\
1874.9-1875.1\end{array}$ \\
\hline $\begin{array}{l}8(1,4,7,10 \\
13,16,19,22)\end{array}$ & $1875.2-1878.12$ & $1877.5-1887$ & $1875.2-1878.12$ & $2 ! 1875.2-1878.12$ & $1875.2-1878.12$ \\
\hline $\begin{array}{l}24(1-24) \\
4(1,7,13,19) \\
4(2,8,24,20)\end{array}$ & $\begin{array}{l}1879.1-1950 \\
1954-1960.7 \\
1951-1953 \\
1960.8-1983\end{array}$ & $\mid \begin{array}{l}1879.1-1950 \mid \\
1954-1960.7 \\
1951-1953 \\
1960.8-1983\end{array}$ & $\begin{array}{l}1884.3-1950 \\
1954-1960.7 \\
1951-1953 \\
1960.8-1983\end{array}$ & $\begin{array}{l}: 879.1-1950 \\
: 954-1960.7 \\
2951-1953 \\
: 960.8-1983\end{array}$ & $\begin{array}{l}1879.1-1950 \\
1954-1960.7 \\
1951-1953 \\
1960.8-1983\end{array}$ \\
\hline
\end{tabular}

D. Remarks :

$\therefore$ Date divided time: $24120^{\circ}$ E mean tume before 1951 $20120^{\circ} \varepsilon$ mean $t$ ime after 1951 
No. $46 \quad 58424$ An Qins

A. Main Data Sources
1. $1931-1942$
2. $1950.4-1980$
3. $1981-1983$
$(2)(3)(15)$
(119)
(13)

B. Location of Station, TIme Standard and Ilmes of Observatlons.

\begin{tabular}{|c|c|c|c|c|c|c|}
\hline $\begin{array}{c}\text { Observational } \\
\text { Pertod }\end{array}$ & Address & $\left|\begin{array}{l}\text { Locatioo } \\
\text { Lat.N }\end{array}\right|$ & $\begin{array}{l}a \text { of stat } \\
\text { Los. }\end{array}$ & $\left|\begin{array}{l}10 \mathrm{n} \\
\mathrm{E}(\mathrm{M})(\mathrm{PH})\end{array}\right|$ & $\left\{\begin{array}{c}\text { Iime zone } \\
\text { system }\end{array}\right.$ & $\begin{array}{l}\text { Times of } \\
\text { observations }\end{array}$ \\
\hline $\begin{array}{l}1931-1938 \\
1950.4-1953\end{array}$ & $\begin{array}{l}\text { No.3 finance } \\
\text { street (tn } \\
\text { c1ty) }\end{array}$ & $\left|\begin{array}{ll}30^{\circ} & 37^{\prime} \\
30^{\circ} & 37^{\prime}\end{array}\right|$ & $\begin{array}{ll}117^{\circ} & 04 \\
117^{\circ} & 02 \\
\end{array}$ & $\begin{array}{c}- \\
26.3 \\
(31.0)\end{array}$ & $\begin{array}{c}(\text { Be1jing } \\
\text { time })\end{array}$ & $24(1-24)$ \\
\hline $1954-1956$ & $\begin{array}{l}\text { In garden of } \\
\text { melitary su- } \\
\text { baras (in } \\
\text { ctty) }\end{array}$ & $30^{\circ} 32^{\prime}$ & $117^{\circ} 02^{\circ}$ & $\begin{array}{c}38.4 \\
(39.5)\end{array}$ & $\begin{array}{l}\text { Local mean } \\
\text { solar t1san }\end{array}$ & $4(1,7,13,19)$ \\
\hline $1957-1959.11$ & $\begin{array}{l}\text { Hale and two } \\
\text { L1 North } \\
\text { gate out } \\
\text { coumtryside }\end{array}$ & $30^{\circ} 31^{\prime}$ & $117^{\circ} 02^{\prime}$ & $\begin{array}{c}40.9 \\
(42.7)\end{array}$ & $\begin{array}{l}\text { Local wean } \\
\text { solar time }\end{array}$ & $4(1,7,13,19)$ \\
\hline & As above & $30^{\circ} 31^{\prime}$ & $117^{\circ} 02^{\prime}$ & $\begin{array}{c}42.2 \\
(40.7)\end{array}$ & $\begin{array}{l}\text { Local mean! } \\
\text { solar tire }\end{array}$ & $4(1,7,13,19)$ \\
\hline $1960-1961.1$ & As above & $30^{\circ} 31^{\prime}$ & $117^{\circ} 02^{\prime}$ & $\left(\begin{array}{c}42.2 \\
(40.7)\end{array}\right.$ & $\begin{array}{c}\text { (Beifjing } \\
\text { timo) }\end{array}$ & $4(2,8,18,20)$ \\
\hline $1961.2-1964.9$ & As above & $30^{\circ} 31^{\circ}$ & $117^{\circ} 02^{\circ}$ & $\begin{array}{c}42.2 \\
(43.6)\end{array}$ & $\begin{array}{c}\text { (Beijjag } \\
\text { ine }\end{array}$ & $4(2,8,18,20)$ \\
\hline & As above & $30^{\circ} 31^{\prime}$ & $117^{\circ} 02^{\prime}$ & $\mid \begin{array}{c}44.0 \\
(45.4)\end{array}$ & $\mid \begin{array}{c}\text { (Beijing } \\
\text { time })\end{array}$ & $4(2,8,18,20)$ \\
\hline $1977.1-1983$ & $\begin{array}{l}\text { Wang Jia the } \\
\text { house DaQins } \\
\text { road (Korth } \\
\text { suburb) }\end{array}$ & $30^{\circ} 32$ & $117^{\circ} 03^{\circ}$ & $\begin{array}{l}19.8 \\
(19.6)\end{array}$ & $\begin{array}{c}\text { (BeIJ1ng } \\
t \pm \operatorname{tmo})\end{array}$ & $4(2,8,18,20)$ \\
\hline
\end{tabular}

C. Number of Observations Used for Calculating the Daily Mean

\begin{tabular}{|c|c|c|c|c|}
\hline Mean itmes & $\mid \begin{array}{c}\text { Mean pressure } \\
\text { (Period) }\end{array}$ & $\begin{array}{r}\text { Temperature } \\
\text { (Perlod) }\end{array}$ & $\begin{array}{l}\text { Reiat1ve } \\
\text { humidtty } \\
\text { (Portod) }\end{array}$ & $\begin{array}{l}\text { Wind } \\
\text { (Poriod) }\end{array}$ \\
\hline $\begin{array}{l}24(1-24) \\
4(1,7,13,19) \\
4(2,8,24,20)\end{array}$ & $\begin{array}{l}1950.4-1953 \\
1954-1959 \\
1960-1983\end{array}$ & $\begin{array}{l}1950.4-1953 \\
1954-1959 \\
1960-1983\end{array}$ & \begin{tabular}{|l}
$1950.4-1953$ \\
$1954-1959$ \\
$1960-1983$
\end{tabular} & $\begin{array}{l}1950.4-1953 \\
1954-1959 \\
1960-1983\end{array}$ \\
\hline
\end{tabular}

כ. Remariks:

$\therefore$ The vartation of height 10 :964.10 was due to the variation of starting point of the helght above sea level (from Wh Song mouth-Buang Eat).

2. The difference of pressure height for 1961.2-1964.9 and 1964.10-i:96.12 periods had been corrected.

3.016 name: " Eual N1ng ". 
No. $47 \quad 58457$ Hang Zhou

A. Main Data Sources
1. $1904-1950$
2. $1951-1970$
3. $1971-1980$
4. $1981-1983$

B. Location of Station. I me Standard and itses of Observations.

\begin{tabular}{|c|c|c|c|c|c|c|}
\hline $\begin{array}{l}\text { Observational } \\
\text { Period }\end{array}$ & Address & $\begin{array}{l}\text { Locatior } \\
\text { Lat.N }\end{array}$ & |n of stati & $\mathrm{H}(\mathrm{M})(\mathrm{PH})$ & $\mid \begin{array}{c}\text { I1me zone } \\
\text { system }\end{array}$ & $\begin{array}{l}\text { Times of } \\
\text { observations }\end{array}$ \\
\hline $\begin{array}{l}1904-1918 \\
1919-1932 \\
1933 \\
1934.1-9\end{array}$ & $\mid \begin{array}{l}\text { General road } \\
\text { (1n c1ty) } \\
\text { As above }\end{array}$ & $\left|\begin{array}{ll}30^{\circ} & 11 \\
30^{\circ} & 16^{\prime} \\
30^{\circ} & 16^{\prime} \\
30^{\circ} & 16^{\prime}\end{array}\right|$ & $\left|\begin{array}{ll}120^{\circ} & 12^{\prime} \\
120^{\circ} & 10^{\prime} \\
120^{\circ} & 10^{\circ} \\
120^{\circ} & 10^{\circ}\end{array}\right|$ & $\mid \begin{array}{l}10.0 \\
10.0 \\
10.0 \\
10.0\end{array}$ & $\left|\begin{array}{ll}120^{\circ} & \text { E.M.T } \\
120^{\circ} & \text { E.M.T } \\
120^{\circ} & \text { E.M.T } \\
120^{\circ} & \text { E.M.T }\end{array}\right|$ & $\left|\begin{array}{c}3(6,14,22) \\
- \\
6(6,9,12,15 \\
18,21) \\
7(6,9,12,14\end{array}\right|$ \\
\hline $\begin{array}{l}1934.10-1937 \\
1942 \\
1945-1947\end{array}$ & $\begin{array}{l}\text { As above } \\
\text { No. } 14 \text { Llans } \\
\text { Dao Shan }\end{array}$ & 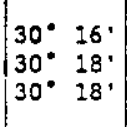 & $\begin{array}{ll}120^{\circ} & 10^{\prime} \\
120^{\circ} & 02 \\
120^{\circ} & 02\end{array}$ & 10.0 & $\begin{array}{l}120^{\circ} \text { E.M.T } \\
120^{\circ} \text { E.M.T } \\
120^{\circ} \text { E.M.I }\end{array}$ & $\left|\begin{array}{c}15,18,21) \\
24(1-24) \\
4(6,9,14,21)\end{array}\right|$ \\
\hline 1950.1 & $\begin{array}{l}\text { Jian Q1ao } \\
\text { airport }\end{array}$ & $30^{\circ} 20^{\circ}$ & $120^{\circ} 14^{\prime}$ & 7.7 & $120^{\circ}$ E.M.T & $16(6-21)$ \\
\hline $1950.2-1952$ & As above & $30^{\circ} 20^{\circ}$ & $120^{\circ}: 14^{\prime}$ & $\begin{array}{c}7.7 \\
(8.5)\end{array}$ & 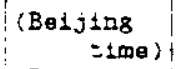 & $24(1-24)$ \\
\hline$: 953.2-4$ & $\mid \begin{array}{l}X 1 n \text { Min ail- } \\
\text { ey, Ee Fang } \\
\text { street (in } \\
\text { city) }\end{array}$ & $30^{\circ} 15^{\prime}$ & $120^{\circ}: 20^{\circ}$ & $(13.0$ & $\left(\begin{array}{c}(B \theta+j i n g \\
t \pm 0 \theta\end{array}\right.$ & $24(1-24)$ \\
\hline 1953.5 & As above & $30^{\circ} 15^{\circ}$ & $120^{\circ}: 0^{\circ}$ & $\begin{array}{c}11.6 \\
(13.4)\end{array}$ & $\begin{array}{c}\text { (Beijing } \\
\text { time })\end{array}$ & $24(1-24)$ \\
\hline $1953.6-12$ & As above & $30^{*} 15^{\prime}$ & $120^{\circ}: 0^{\circ}$ & $\begin{array}{l}11.6 \\
(19.9)\end{array}$ & $\left|\begin{array}{c}(B \theta i j \operatorname{lng} \\
t \pm m \theta\end{array}\right|$ & $24(1-24)$ \\
\hline 1954 & As above & $30^{\circ} 15^{\circ}$ & $120^{\circ} 10^{\circ}$ & $\begin{array}{l}11.6 \\
(19.9)\end{array}$ & Local time & $4(1,7,23,19)$ \\
\hline $1955.1-6$ & $\begin{array}{l}\text { Gong Then Br- } \\
\text { idge suburb }\end{array}$ & $30^{\circ} 20^{\circ}$ & $120^{\circ}: 0^{\circ}$ & $\begin{array}{l}5.3 \\
(7.6)\end{array}$ & Local time & $4(1,7,13,19)$ \\
\hline $1955.7-1958$ & As above & $30^{\circ} 20^{\circ}$ & $120^{\circ} \div 0^{\circ}$ & $\begin{array}{c}5.3 \\
(6.0)\end{array}$ & Local time & $4(1,7,13,19)$ \\
\hline $1959-1960.7$ & $\begin{array}{l}\text { Pond temple } \\
\text { GenShan gate } \\
\text { out (countr- } \\
\text { yside) }\end{array}$ & $30^{\circ} 19^{\circ}$ & $120^{\circ} \div 2^{\circ}$ & $\begin{array}{c}7.2 \\
(8.0)\end{array}$ & Local time & $4(1,7,13,19)$ \\
\hline$: 960.8-1970$ & As above & $30^{\circ} 19^{\circ}$ & $120^{\circ} 12^{\circ}$ & $\begin{array}{c}7.2 \\
(8.0)\end{array}$ & (Beijing & $4(2,8,18,20)$ \\
\hline $1970-1983$ & $\begin{array}{l}\text { FengShan ga- } \\
\text { te steamed } \\
\text { bun hill top }\end{array}$ & $30^{\circ} 14^{\circ}$ & $120^{\circ} 10^{\circ}$ & $\begin{array}{l}41.7 \\
---\end{array}$ & $\begin{array}{l}\text { (Beijing } \\
\text { time) }\end{array}$ & $4(2.8$ \\
\hline
\end{tabular}

C. Number of Observations Used for Caleulating the Daily Mean

\begin{tabular}{|c|c|c|c|c|}
\hline Mean times & $\left\{\begin{array}{c}\text { Mean pressura } \\
\text { (Period) }\end{array}\right.$ & $\begin{array}{r}\text { Temperature } \\
\text { (Pertod) }\end{array}$ & $\begin{array}{l}\text { Relative } \\
\text { humidity } \\
\text { (Period) }\end{array}$ & $\begin{array}{l}\text { Wind } \\
\text { (Period) }\end{array}$ \\
\hline $\begin{array}{l}(---- \\
3(6,14,22) \\
3(6,14,22) \\
24(1-24) \\
4(1,7,13,19) \\
4(2,8,14,20)\end{array}$ & \begin{tabular}{|l|}
1933 \\
$1904-1918$ \\
$1934-1937.1950$ \\
$1950.2-1953$ \\
$1954-1960.7$ \\
$1960.8-1983$
\end{tabular} & \begin{tabular}{|l}
$1919-1933,1942$ \\
$1945-1947$ \\
$1904-1918$ \\
$1934-1937,1950$ \\
$1950.2-1953$ \\
$1954-1960.7$ \\
$1960.8-1983$
\end{tabular} & $\begin{array}{l}1933,1942 \\
1945-1947 \\
1904-1918 \\
1934-1937,1950 \\
: 950.2-1953 \\
1954-1960.7 \\
: 960.8-1983\end{array}$ & $\begin{array}{l}2951-1953 \\
2954-1960.7 \\
1960.8-1983\end{array}$ \\
\hline
\end{tabular}

D. Remarks: 
No. 4858606 Nan Chang

A. Main Data Sources
1. $1929-1950$
(123)
2. 1951-1962
3. $1963-1970$
4. $1951-1980$
5. $1971-1980$
(124)
6. 1981-1983
(125)
(159)
(13)

B. Location of Station, IIme Standard and Times of Observations.

\begin{tabular}{|c|c|c|c|c|c|c|}
\hline $\begin{array}{c}\text { Observational } \\
\text { Pertod }\end{array}$ & Addrass & $\mid \begin{array}{l}\text { Locatiox } \\
\text { Lat.N }\end{array}$ & $\begin{array}{l}\text { a of stat } \\
\text { LoN.E }\end{array}$ & $|\mathrm{E}(\mathrm{M})(\mathrm{PH})|$ & $\begin{array}{c}\text { Time 2one } \\
\text { systed }\end{array}$ & $\begin{array}{l}\text { Times of } \\
\text { observations }\end{array}$ \\
\hline 1936 & YuZhang parix & $\mid \begin{array}{ll}28^{\circ} & 42^{\prime} \\
28^{\circ} & 41^{\prime}\end{array}$ & $\left|\begin{array}{ll}115^{\circ} & 51^{\prime} \\
115^{\circ} & 54^{\prime}\end{array}\right|$ & & Local time & 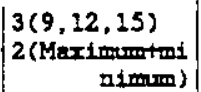 \\
\hline $\begin{array}{l}1937 \\
1938.2-6\end{array}$ & $\begin{array}{l}\text { As above } \\
\text { As above }\end{array}$ & $\begin{array}{l}28^{\circ} 41^{\prime} \\
28^{\circ} 41^{\prime}\end{array}$ & $\begin{array}{ll}115^{\circ} & 54^{\circ} \\
115^{\circ} & 54^{\prime}\end{array}$ & & $\begin{array}{l}\text { locai time } \\
120^{\circ} \text { E.M.I }\end{array}$ & $8(3,6,9,12$, \\
\hline $\begin{array}{l}1938 . \\
1938 .\end{array}$ & $\begin{array}{l}\text { As above } \\
\text { As bove }\end{array}$ & $\begin{array}{l}28^{\circ} 41^{\prime} \\
28^{\circ} \\
41^{\prime}\end{array}$ & $\mid \begin{array}{ll}115^{\circ} & 54^{\prime} \\
1115^{\circ} & 54^{\prime}\end{array}$ & & $\begin{array}{l}120^{\circ} \text { E.M.T } \\
120^{\circ} \text { E.M.T }\end{array}$ & $\mid \begin{array}{c}3(6,14,21) \\
6(6,9,12,14, \\
: 8,21)\end{array}$ \\
\hline $\begin{array}{l}1946-1 \\
1948.1\end{array}$ & Jin wai Mon- & $28^{\circ} 34^{\prime}$ & 年- & 26.0 & 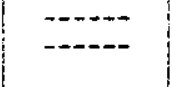 & $16(5-21)$ \\
\hline $1950.6-1952$ & $\begin{array}{l}\text { San Jia Dian } \\
\text { (suburb) }\end{array}$ & $28^{\circ} 40^{\circ}$ & $115^{\circ} 58^{\circ}$ & 26.4 & ----- & $24(1-24)$ \\
\hline $\begin{array}{l}1953 \\
1954-1960.6\end{array}$ & $\begin{array}{l}\text { As above } \\
\text { Dens ports }\end{array}$ & $\begin{array}{l}28^{\circ} 40^{\circ} \\
28^{\circ} 40^{\circ}\end{array}$ & $\begin{array}{l}115^{\circ} 58^{\prime} \\
115^{\circ} 58^{\prime}\end{array}$ & $\mid \begin{array}{l}27.8 \\
46.7\end{array}$ & $\begin{array}{l}\text {------ } \\
\text { Local meac } \\
\text { solar timo }\end{array}$ & $\left\{\begin{array}{l}24(1-24) \\
4(1,7,23,19)\end{array}\right.$ \\
\hline $1960.7-1977$ & As above & $28^{\circ} 40^{\circ}$ & $125^{\circ} 58^{\prime}$ & 46.7 & $\begin{array}{c}\text { (Betjing } \\
\text { t100 }\end{array}$ & $4(2,8,18,20)$ \\
\hline $1978-1983$ & As abova & $28^{\circ} 36^{\prime}$ & $115^{\circ} 55^{\prime}$ & 46.7 & $\begin{array}{c}(B 01 j 108 \\
\text { time })\end{array}$ & $4(2,8,18,20)$ \\
\hline
\end{tabular}

C. Number of Observations Used for Caiculating the Daily Mean

\begin{tabular}{|c|c|c|c|c|}
\hline Mean tyes & $\left\{\begin{array}{c}\text { Mean pressure } \\
\text { (Period) }\end{array}\right.$ & $\begin{array}{r}\text { Temperature } \\
\text { (Perlod) }\end{array}$ & $\begin{array}{l}\text { Relative } \\
\text { humidtty } \\
\text { (Period) }\end{array}$ & $\begin{array}{l}\text { Wind } \\
\text { (Period) }\end{array}$ \\
\hline 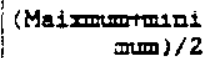 & & 1936 & & \\
\hline $3(6,14,21)$ & & $\begin{array}{l}1937-1938.9 \\
1948.10-1949.2\end{array}$ & $\begin{array}{l}1936.7-1938.9 \\
1948.10-1949.2\end{array}$ & \\
\hline $\begin{array}{l}3(9,12,15) \\
24(1-24) \\
4(1,7,23,19) \\
4(2,8,14,20)\end{array}$ & $\left\{\begin{array}{l}1950.6-1953 \\
1954-1960.6 \\
1960.7-1983\end{array}\right.$ & \begin{tabular}{|l|}
$1929-1935$ \\
$1950.6-1953$ \\
$1954-1960.6$ \\
$1960.7-1983$
\end{tabular} & $\begin{array}{l}1950.1-1953 \\
1954-1960.6 \\
1960.7-1983\end{array}$ & $\begin{array}{l}951-1953 \\
: 954-1960.6 \\
: 960.7-1983\end{array}$ \\
\hline
\end{tabular}

D. Remarks: 


\section{B-56}

No. 4958633 Qu Zhou

A. Main Data Sources

$\begin{array}{ll}\text { i. } 1951-1970 & (127) \\ \text { 2. } 1971-1980 & (128)(159) \\ \text { 3. } 1981-1983 & (13)\end{array}$

E. Location of Station, Iime Standard and Ilmes of Observations.

\begin{tabular}{|c|c|c|c|c|c|c|c|c|}
\hline $\begin{array}{c}\text { Cbservacionai } \\
\text { Perlod }\end{array}$ & Address & $\begin{array}{l}\text { Loce } \\
\text { Lat }\end{array}$ & $N$ & $\begin{array}{l}\text { a of } 5 \\
\text { LoN.E }\end{array}$ & stati & $\begin{array}{l}\text { ion } \\
\text { I }\end{array}$ & $\begin{array}{c}\text { Tloe zone } \\
\text { system }\end{array}$ & $\begin{array}{l}\text { Times of } \\
\text { abservations }\end{array}$ \\
\hline $951.1-2$ & Qus Zhou & $28^{\circ}$ & $58^{\prime}$ & $118^{\circ}$ & $53^{\prime}$ & $\begin{array}{l}68.6 \\
(72.8)\end{array}$ & $\begin{array}{c}(B 01 j \operatorname{lng} \\
\operatorname{tin} \theta)\end{array}$ & $24(1-24)$ \\
\hline $2951.2-1952.1$ & $\begin{array}{l}\text { Qu Chou Fu } \\
\text { hild }\end{array}$ & $28^{\circ}$ & $58^{\circ}$ & $118^{\circ}$ & 531 & $\begin{array}{c}80.3 \\
(80.8)\end{array}$ & $\begin{array}{c}(B e i j 108 \\
\pm 1 m \theta)\end{array}$ & $24(1-24)$ \\
\hline $1952.2-1953$ & As above & $28^{\circ}$ & $58^{\circ}$ & $128^{\circ}$ & $53^{\circ}$ & $\begin{array}{c}80.0 \\
(80.8)\end{array}$ & $\begin{array}{c}(B \in \pm j 1 n g \\
t \pm 00)\end{array}$ & $24(1-24)$ \\
\hline 1954 & $\begin{array}{l}\text { East city } \\
\text { (suburb) }\end{array}$ & $28^{\circ}$ & $58^{\prime}$ & $118^{\circ}$ & $53^{\prime}$ & $\left(\begin{array}{l}80.0 \\
(---)\end{array}\right.$ & Local time & $4(1,7,13,19)\}$ \\
\hline i955.2-9 & As above & $28^{\circ}$ & $58^{\prime}$ & $118^{\circ}$ & $53^{\prime}$ & $\begin{array}{c}62.0 \\
(63.0)\end{array}$ & Local timo & $4\langle 1,7,23,19$ \\
\hline $1955.10-1960.7$ & $\begin{array}{l}\text { Northern } 8 \mathrm{a}- \\
\text { te out } \\
\text { (suburb) }\end{array}$ & $28^{\circ}$ & $58^{\prime}$ & $118^{\circ}$ & $52^{\prime}$ & $\begin{array}{c}66.1 \\
(67.1)\end{array}$ & Local time & $4(1,7,13,19)$ \\
\hline$: 960.8-1974.2$ & As above & $28^{\circ}$ & 58 ' & $118^{\circ}$ & $52 !$ & $\begin{array}{l}66.1 \\
(67.1)\end{array}$ & 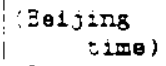 & $14(2,8,28,20)$ \\
\hline $2974.3-1975.6$ & As above & $28^{\circ}$ & $58^{\circ}$ & $118^{\circ}$ & $52 \cdot$ & $\begin{array}{c}66.1 \\
(71.0)\end{array}$ & $\begin{array}{c}(\text { Deljing } \\
\text { i2me })\end{array}$ & $4(2,8,18,20)$ \\
\hline $2975.7-1976$ & As above & $28^{\circ}$ & $58^{\prime}$ & $118^{\circ}$ & $52 \cdot$ & $\begin{array}{c}66.7 \\
(71.0)\end{array}$ & $\begin{array}{r}(\operatorname{Betjing} \\
\text { time })\end{array}$ & $4(2,8,18,20)$ \\
\hline $1977-1983$ & As above & $28^{\circ}$ & $58^{\prime}$ & $118^{\circ}$ & $52^{\prime}$ & $\begin{array}{c}66.9 \\
(72.0)\end{array}$ & $\begin{array}{c}(391 j i n g \\
\text { tIme })\end{array}$ & $4(2,8,18,20) !$ \\
\hline
\end{tabular}

C. Number of Observations Used for Calculating the Dałly Mean

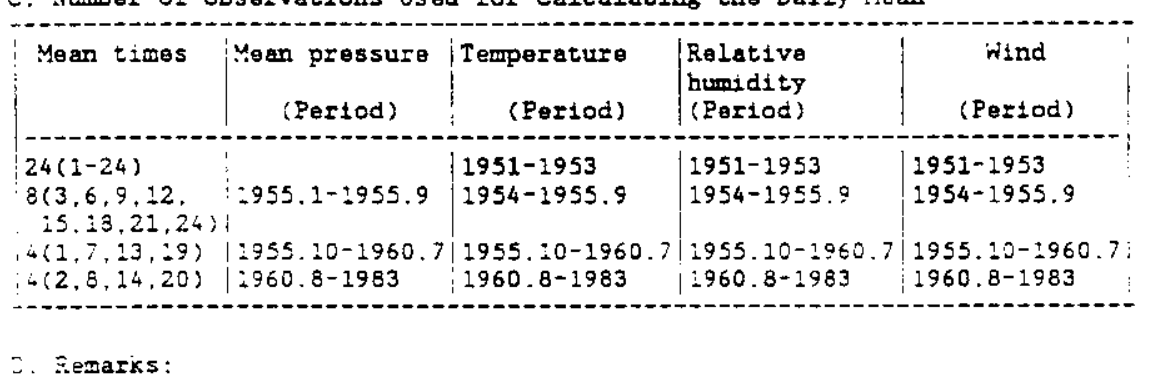


A. Main Data Sources
1. $1883-1950$
2. $1951-1970$
3. 1971-1980
4. 1981-1983
(129)
(130)
(159)(131)
5. $1951-1954$
(13)
(12)

B. Location of Station. Time Standard and Times of Observations.

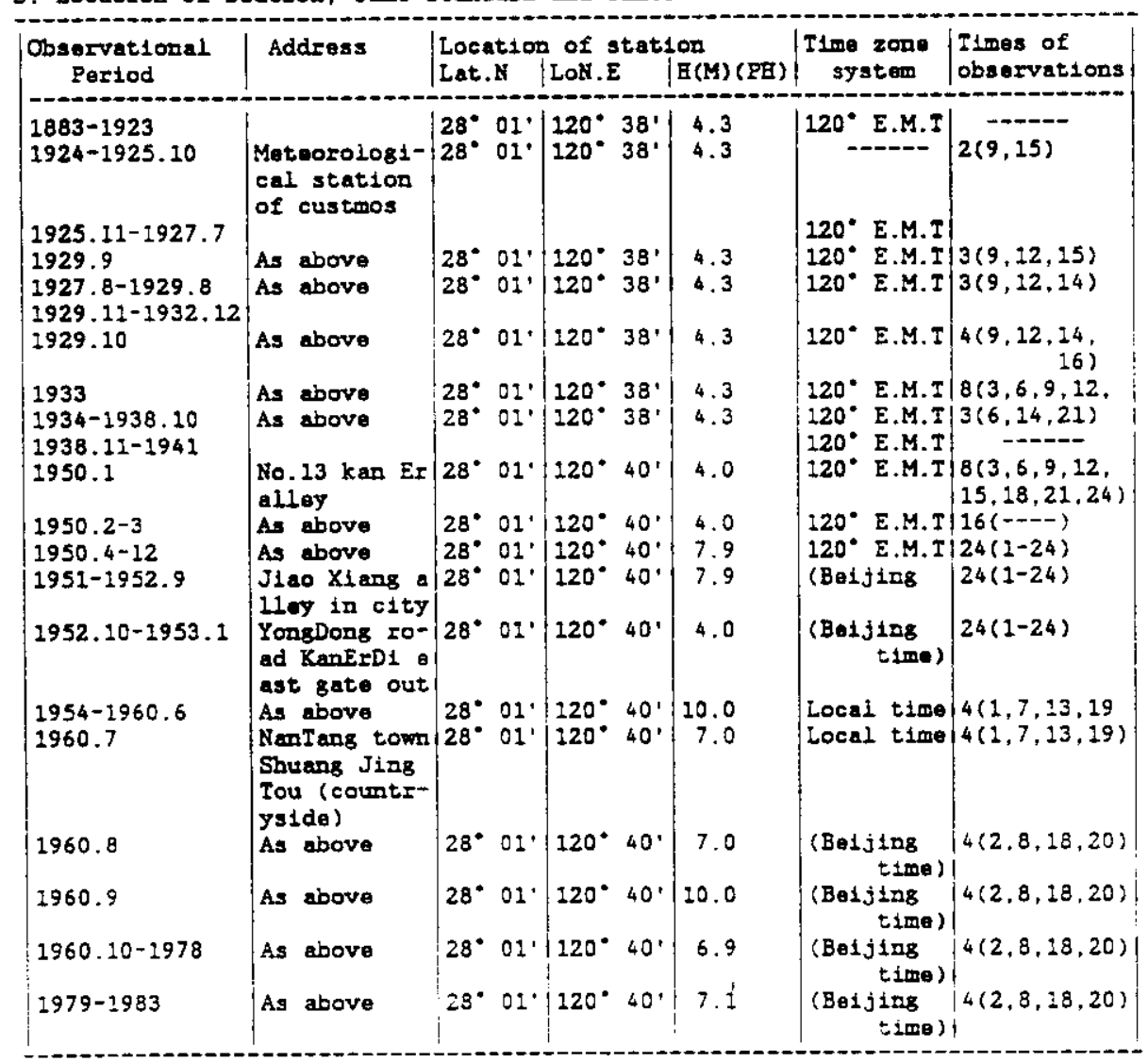




\section{B-58}

No. 5058659 Wen Thou (cont.)

c. Number of Observations Used for Calculating the Dałiy Mean

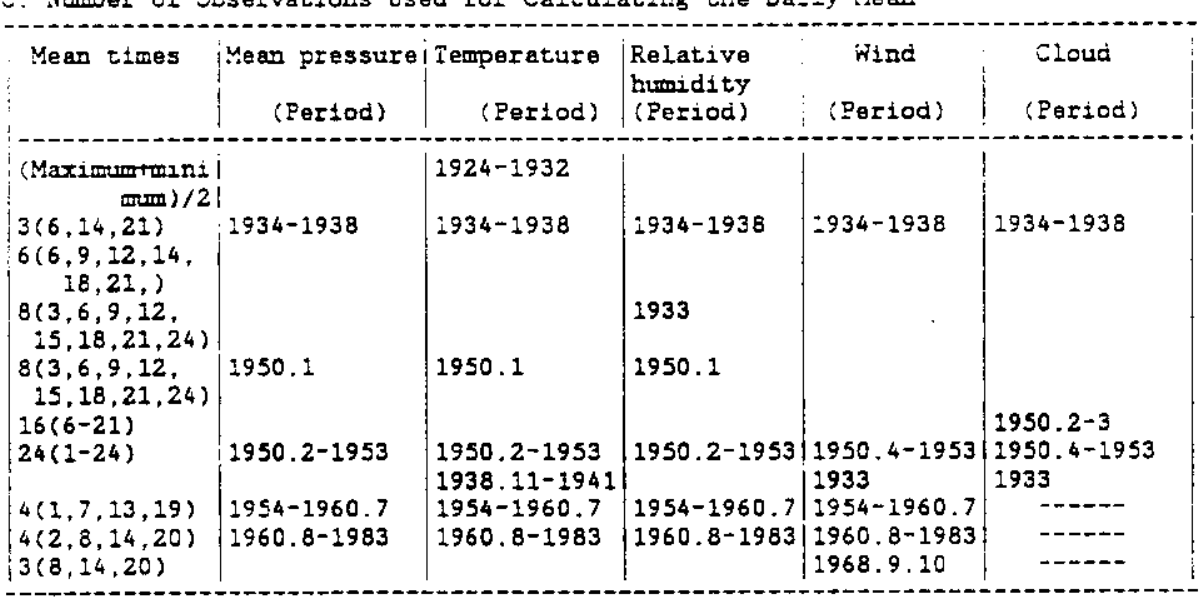

D. Remarks :

. Old name: "Yong Jia" 
A. Maln Data Sources
1. $1880-1944$
2. $1945-1950$
(133)
3. 1951-1980
(134)
4. 1981-1983
5. $1905-1923$ 1946-1947
6. $1928-1938$

B. Location of Station. Time Standard and Times of Observations.

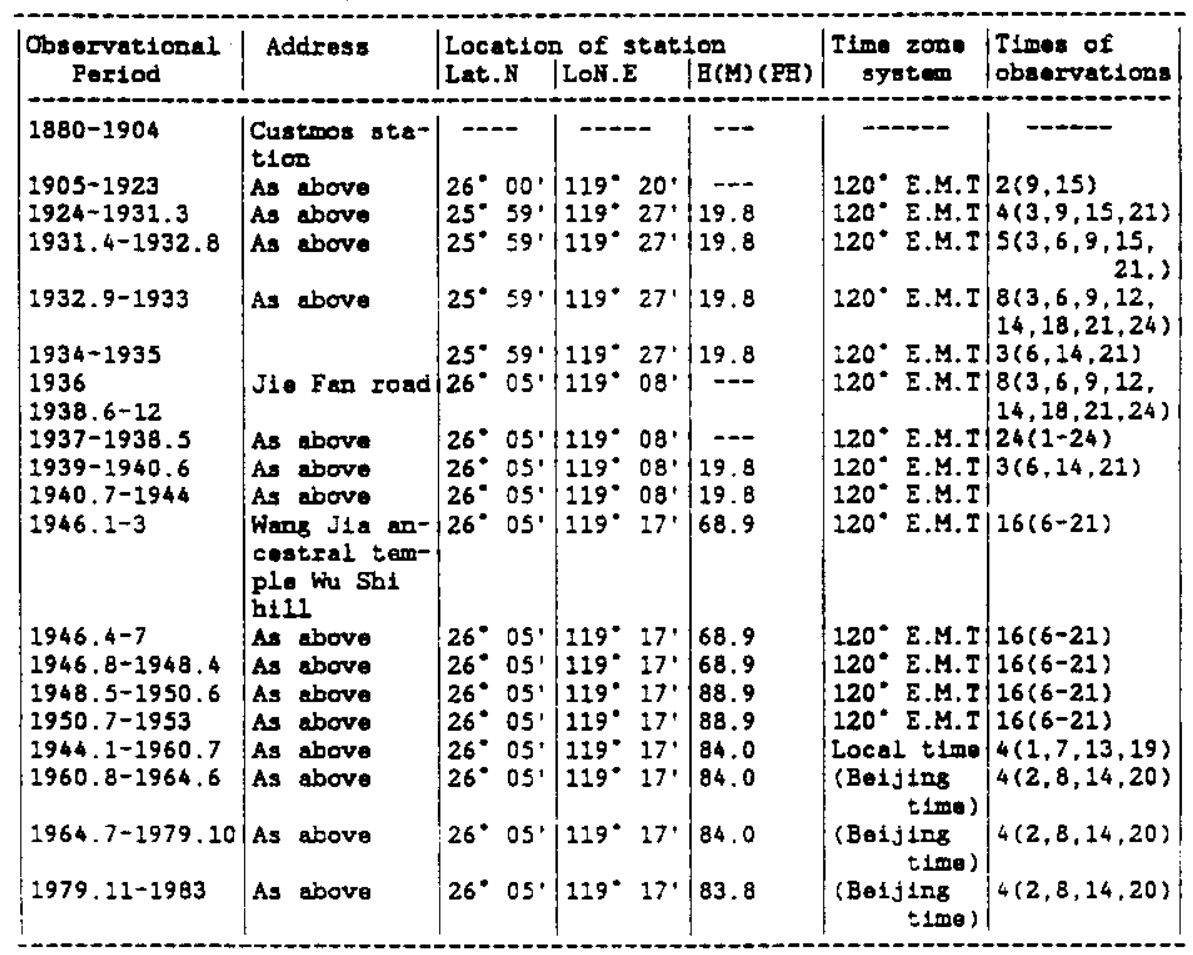

C. Number of Observations Used for Calculating the Datly Mean

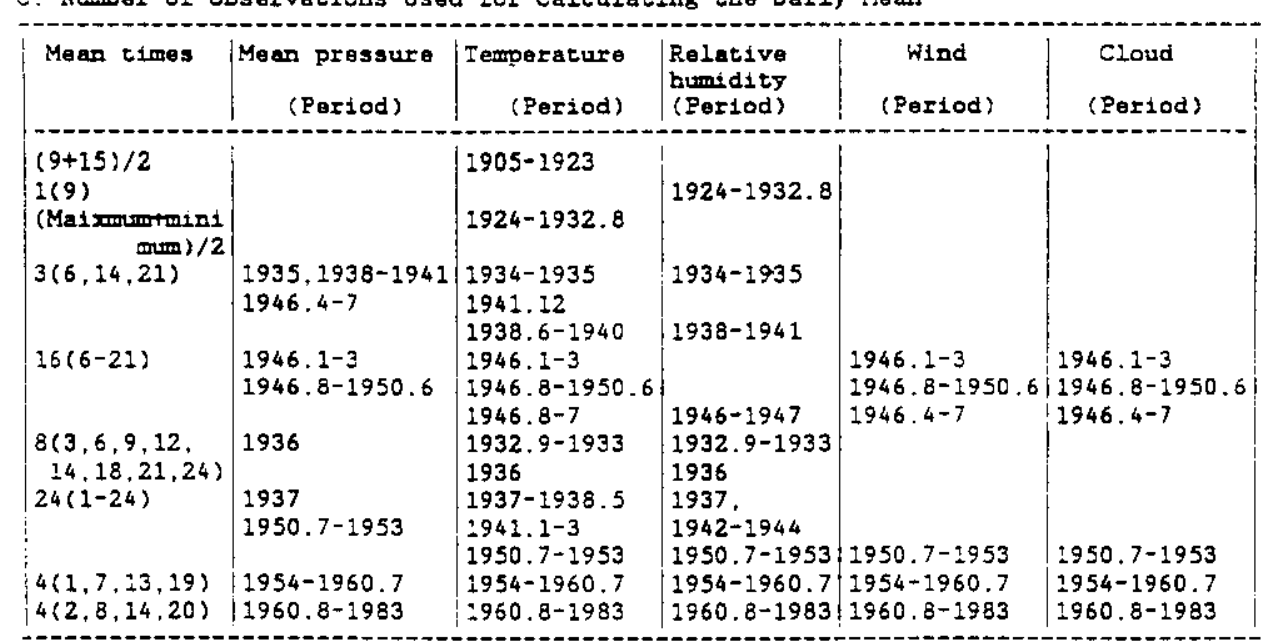

₹. Remarks : 
A. Main Data Sources

$\begin{array}{lr}\text { ¿. } 1938-1950 & (135) \\ \text { 2. } 1951-1980 & (136) \\ \text { 3. } 1981-1983 & (13) \\ \text { 4. } 1951-1954 & (12)\end{array}$

3. Location of Station, Itme Standard and Times of Observations.

\begin{tabular}{|c|c|c|c|c|c|c|}
\hline $\begin{array}{l}\text { Observationai } \\
\text { Period }\end{array}$ & Address & $\begin{array}{l}\text { Locatioz } \\
\text { Lat.N }\end{array}$ & $\begin{array}{l}\text { D of stat } \\
\mid \text { LON.E }\end{array}$ & 10n & $\begin{array}{c}\text { Time zone } \\
\text { systete }\end{array}$ & $\begin{array}{l}\text { Times of } \\
\text { observations }\end{array}$ \\
\hline $\begin{array}{l}1938-1939.5 \\
1939.6-1940.1\end{array}$ & $\begin{array}{l}\text { Mao Ptng vil- } \\
\text { lage }\end{array}$ & $\left|\begin{array}{ll}25^{\circ} & 58^{\prime} \\
25^{\circ} & 58^{\prime}\end{array}\right|$ & $\left|\begin{array}{ll}117^{\circ} & 21 \\
117^{\circ} & 21\end{array}\right|$ & & $\left|\begin{array}{ll}120^{\circ} & \text { E.M.T } \\
120^{\circ} & \text { E.M.T }\end{array}\right|$ & $\mid \begin{array}{l}16(6-21) \\
16(6-21)\end{array}$ \\
\hline $1940.2-9$ & $\begin{array}{l}\text { South side of } \\
\text { YiEe mountian }\end{array}$ & $25^{\circ} 58^{\circ}$ & $\left|117^{\circ} 21^{\prime}\right|$ & $\mid \begin{array}{l}184.1 \\
(184.1)\end{array}$ & $120^{\circ}$ E.M.I & $16(6-21)$ \\
\hline $\begin{array}{l}1940.10-1948 \\
1950.6-7\end{array}$ & $\begin{array}{l}\text { YiEe mountian } \\
\text { yellow moumt- } \\
\text { fan road new } \\
\text { north gate } \\
\text { out }\end{array}$ & 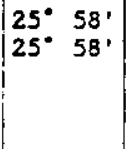 & $\begin{array}{ll}117^{\circ} & 21^{\prime} \\
117^{\circ} & 21^{\circ}\end{array}$ & 210.0 & $\mid \begin{array}{l}120^{\circ} \text { E.M.I } \\
120^{\circ} \text { E.M.I }\end{array}$ & $\begin{array}{l}16(6-21) \\
16(6-21)\end{array}$ \\
\hline $1950.8-12$ & $\begin{array}{l}\text { Thong Shan } \\
\text { Park }\end{array}$ & $25^{\circ} 58^{\prime}$ & $117^{\circ} 21^{\prime}$ & ---- & $\begin{array}{l}\text { Time zone } \\
\text { time }\end{array}$ & S'fł(t1mes $)$ \\
\hline $1951.1-11$ & As above & $25^{\circ} 58^{\circ}$ & $117^{\circ} 211^{\circ}$ & 210.0 & $\begin{array}{l}\text { Time zone } \\
\text { time }\end{array}$ & $3(6,14,21)$, \\
\hline $1951.22-1952.8$ & As above & $25^{\circ} 58^{\circ}$ & $217^{\circ} 21^{\circ}$ & 210.0 & $\begin{array}{l}\text { Time zone } \\
\text { time }\end{array}$ & $\begin{array}{c}6(6,9,12,14 \\
20,21)\end{array}$ \\
\hline $1952.9-1953$ & As above & $25^{\circ} 58^{\circ}$ & $\left|117^{\circ} 211\right|$ & 210.0 & $\begin{array}{l}\text { Time } 20 n e \\
\text { time }\end{array}$ & $16(6-21)$ \\
\hline $\begin{array}{l}1954.1-1960.7 \\
1960.8-1979\end{array}$ & $\begin{array}{l}\text { As above } \\
\text { As above }\end{array}$ & $\begin{array}{l}25^{\circ} 58^{\circ} \\
25^{\circ} \\
58^{\prime}\end{array}$ & $\mid \begin{array}{ll}117^{\circ} & 21 \\
117^{\circ} & 21\end{array}$ & $\begin{array}{l}210.0 \\
208.3\end{array}$ & $\begin{array}{c}\text { Local time } \\
(B e 1 j \operatorname{lng} \\
\text { time })\end{array}$ & $\mid$\begin{tabular}{|l|}
$4(2,7,13,19) \mid$ \\
$|4(2,8,14,20)|$
\end{tabular} \\
\hline $1980.1-1983$ & As above & $25^{\circ} 58^{\prime}$ & $117^{\circ} 21^{\prime} \mid$ & 208.3 & $\begin{array}{c}(B \theta 1 j \operatorname{tng} \\
\operatorname{tim} \theta)\end{array}$ & $4(2,8,14,20)$ \\
\hline
\end{tabular}

c. Number of Observations Used for Calculating the Daily Mean

\begin{tabular}{|c|c|c|c|c|c|}
\hline Mean times & $\begin{array}{c}\text { Mean pressura } \\
\text { (Eeriod) }\end{array}$ & Temperature & $\begin{array}{l}\text { Relativo } \\
\text { humidtty } \\
\text { (Period) }\end{array}$ & $\begin{array}{l}\text { Wind } \\
\text { (Eeriod) }\end{array}$ & $\begin{array}{l}\text { Cloud } \\
\text { (Perlod) }\end{array}$ \\
\hline $\begin{array}{l}3(6,24,21) \\
4(1,7,23,19) \\
16(6-21) \\
24(1-24) \\
4(1,7,-3,19) \\
4(2,8,24,20)\end{array}$ & $\begin{array}{l}1938.10-1948 \\
1940-1947 \\
1948-1950 \\
1953 \\
1954-1960.7 \\
1960.8-1983\end{array}$ & $\begin{array}{l}2938.10-1948 \\
: 954-1960.7 \\
2960.8-1983\end{array}$ & & $1939-1942$ & $\begin{array}{l}1938.10-1948 \\
1951-1952 \\
1953\end{array}$ \\
\hline
\end{tabular}

¿. Remariks : 
A. Main Data Scurces

$\begin{array}{lr}\text { 1. } 1936-1957 & \text { (137) } \\ \text { 2. } 1959-1960 & \text { (12) } \\ \text { 3. } 2961-1970 \text { (me am/max/min tamporature, cloud amoumt } & \text { (157) } \\ \text { 4. } 1961-1980 & \text { and precipltation) } \\ \text { 5. } 1981-1983 & \text { (138) }\end{array}$

B. Location of Station, Time Standard and Iimes of Observations.

\begin{tabular}{|c|c|c|c|c|c|c|}
\hline $\begin{array}{c}\text { Observational } \\
\text { Portod }\end{array}$ & | Address & $\left|\begin{array}{l}\text { Location } \\
\text { Lat.\& }\end{array}\right|$ & $\begin{array}{l}\text { of of stat } \\
\text { |LoS.E }\end{array}$ & $|\mathrm{B}(\mathrm{M})(\mathrm{PH})|$ & \begin{tabular}{|} 
T1me zon: \\
Bystem
\end{tabular} & $\mid \begin{array}{ll}\text { T1mes } & \text { of } \\
\text { observations }\end{array}$ \\
\hline 1936 & $\begin{array}{l}\text { In agrtcult- } \\
\text { ural export- } \\
\text { mant tield }\end{array}$ & $24^{\circ} 28^{\prime}$ & $109^{\circ} 22^{\prime} \mid$ & 107.0 & $\mid 105^{\circ}$ E.M.I $\mid$ & $3(6,14,21)$ \\
\hline $1937-1944.9$ & As above & $24^{\circ} 28^{\prime}$ & $109^{\circ} 22^{\prime}$ & 107.0 & $105^{\circ}$ E.M.T & $\begin{array}{c}6(6,9,12,14 \\
18,21)\end{array}$ \\
\hline $1946-1947$ & As above & $24^{\circ} 28^{\circ}$ & $109^{\circ} 22^{\circ}$ & 107.0 & $105^{\circ}$ E.M.T & $\begin{array}{r}6(6,9,12,14 \\
18,21)\end{array}$ \\
\hline $1948-1951$ & As above & $24^{\circ} 28^{\prime}$ & $109^{\circ} 22^{\circ}$ & ---- & $105^{\circ}$ E.M.T & $\begin{array}{c}6(6,9,12,14, \\
18,21)\end{array}$ \\
\hline $1952-1954.6$ & As above & $24^{\circ} 28^{\circ}$ & $109^{\circ} 22^{\prime}$ & 107.0 & $105^{\circ}$ E.M.I & $\left(\begin{array}{c}6(6,9,12,14, \\
18,21)\end{array}\right.$ \\
\hline $1954.7-1960.7$ & As above & $24^{\circ} 28^{\circ}$ & $109^{\circ} 22^{\prime}$ & 97.6 & $\begin{array}{l}\text { Local momp } \\
\text { solar timo }\end{array}$ & $4(1,7,12,19)$ \\
\hline $1960.8-1983$ & As above & $24^{\circ} 28^{\prime}$ & $109^{\circ} 22^{\circ}$ & 97.6 & \begin{tabular}{|} 
Local mean \\
solar time
\end{tabular} & $4(2,8,14,20)$ \\
\hline
\end{tabular}

C. Number of Observations Uaed for Calculating the Daily Meen

\begin{tabular}{|c|c|c|c|c|}
\hline Mean times & $\left\{\begin{array}{c}\text { Mean pressure } \\
\text { (Perlod) }\end{array}\right.$ & $\mid \begin{array}{r}\text { Temperature } \\
\text { (Pertod) }\end{array}$ & $\begin{array}{l}\text { Relative } \\
\text { bumidity } \\
\text { (Reriod) }\end{array}$ & $\begin{array}{l}\text { Wind } \\
\text { (Period) }\end{array}$ \\
\hline $\begin{array}{l}3(6,14,21) \\
6(6,9,12,14 \\
18,21) \\
8(3,6,9,12 \\
14,18,21,24) \\
4(1,7,13,19) \\
4(2,8,14,20)\end{array}$ & $\begin{array}{l}1936 \\
\\
1937-1944.9 \\
1946-1954.6 \\
1954.7-1960.7 \\
1960.8-1983\end{array}$ & $\mid \begin{array}{l}1936-1944.9 \\
1946-1954.6\end{array}$ & $\begin{array}{l}1936 \\
1937-1944.9 \\
1946-1954.6 \\
\\
1954.7-1960.7 \\
1960.8-1983\end{array}$ & $\begin{array}{l}1936-1944.9 \\
1946-1954.6\end{array}$ \\
\hline
\end{tabular}

D. Remarixs : 
A. Main Data Sources

$\begin{array}{lr}\text { 2. } 1886-1951 & (139) \\ \text { 2. } 1951-1980 & (140) \\ \text { 3. } 1981-1983 \text { (The native pressure) } & (13) \\ \text { 4. } 1929-1933 \text { (The } & (15) \\ 1928-1936 \text { (bumidity) } & \end{array}$

B. Location of Station, IIme Standard and Tlmes of Observations.

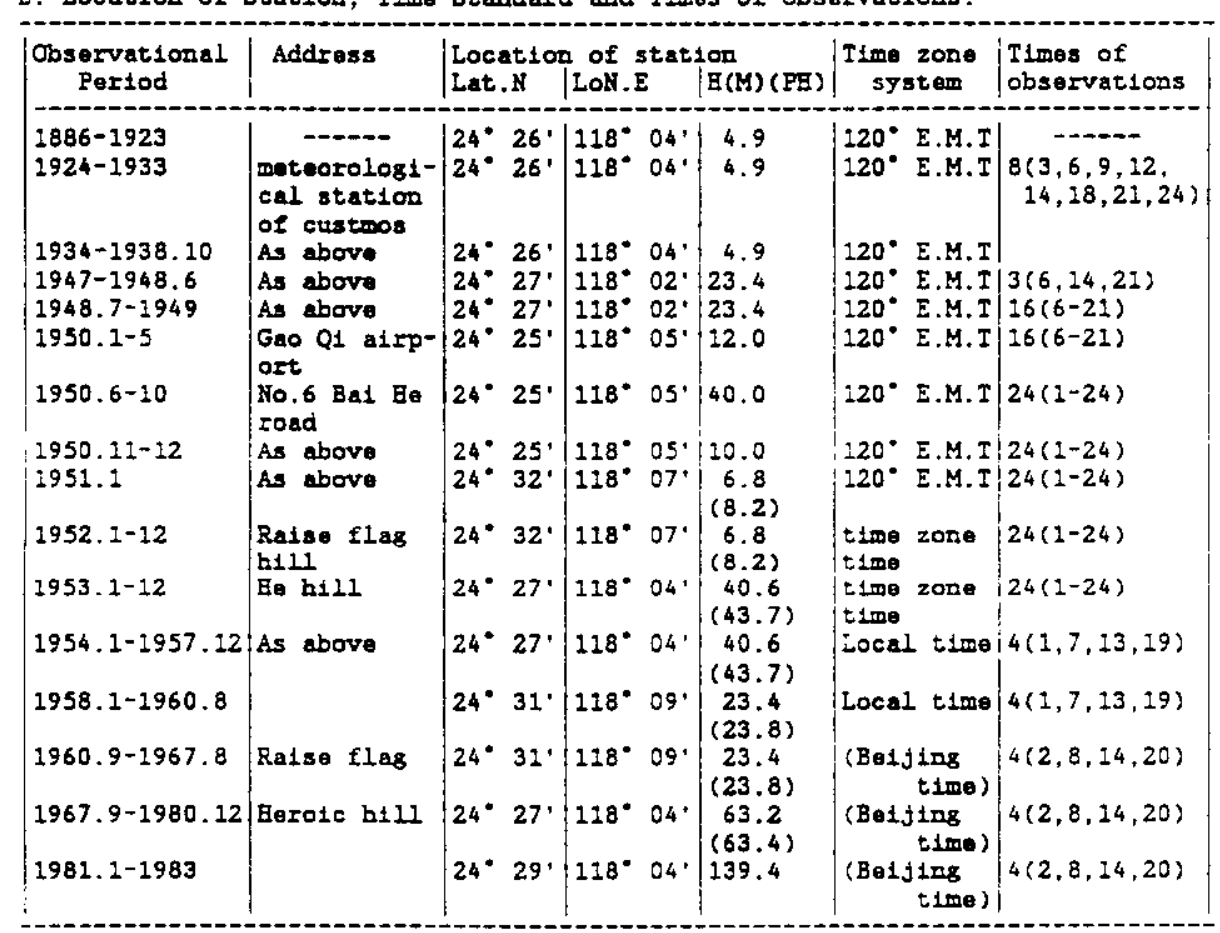

C. Number of Observations Used for Calculating the Datly Mean

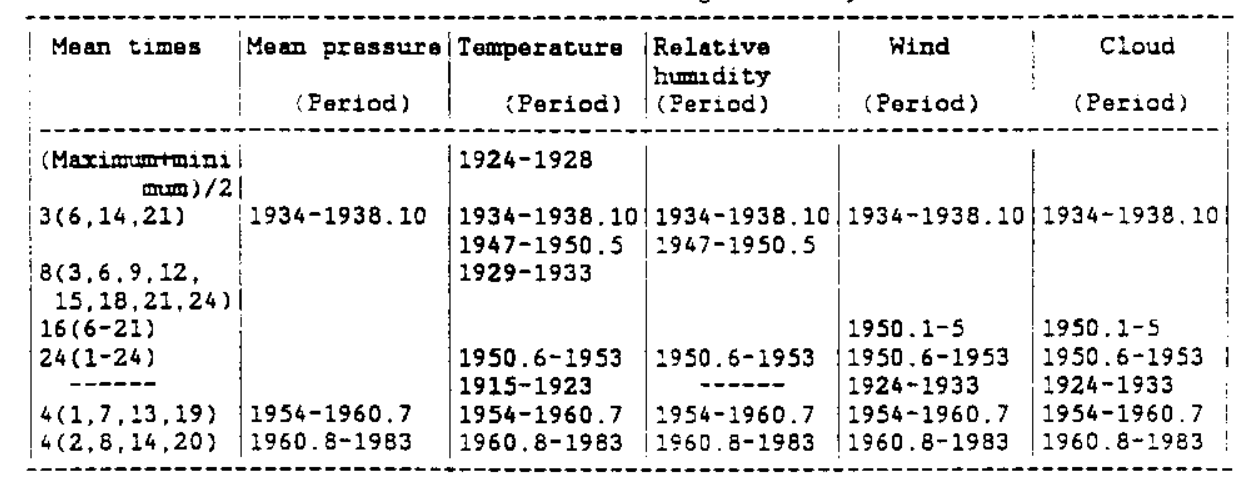

\section{Remarks:}

1. Some records were taken from data source (12) during 1951-1954 per100.

tocation of station: $24^{\circ} 24^{\prime} 118^{\circ} 04^{\prime}$ \&.2(M) in i952.1-7.

$24^{\circ} 24^{\prime}, 118^{\circ} 04^{\circ}, 10.7(\mathrm{M})$ in $1952.8-12$.

$24^{\circ} 24^{\circ}, 118^{\circ} 07^{\circ}: 0.7(\mathrm{M})$ in 1953. 
A. Matn Data Sources

$\begin{array}{lr}\text { 1. } 1898-1957 & (145) \\ \text { 2. } 1924-1950 & (146) \\ \text { 3. } 1951-1960 & (153) \\ \text { 4. } 1951-1960 & (12) \\ \text { 5. } 1961-1970 & (149) \\ \text { 6. } 1981-1983 & (13) \\ \text { 7. } 1961-1970 \text { (modm/max/min tamperature } & \\ \text { a. } 1951.1-1953.2 & (157) \\ \text { and cloud anourt) } & (12)\end{array}$

B. Location of Station, IIme Standerd and Ilmes of Obsorvations.

\begin{tabular}{|c|c|c|c|c|c|c|}
\hline $\begin{array}{l}\text { Observational } \\
\text { Fortod }\end{array}$ & Address & $\left|\begin{array}{l}\text { Locatilon } \\
\text { Lat. B }\end{array}\right|$ & Dof stat: & $|\mathrm{H}(\mathrm{M})(\mathrm{PR})|$ & $\mid \begin{array}{c}\text { Timo zon } \\
\text { system }\end{array}$ & $\begin{array}{l}\text { Times of } \\
\text { observations }\end{array}$ \\
\hline $1898-1927$ & Bydrologic & $23^{\circ} 29^{\prime} \mid$ & $111^{\circ} 18^{\prime}$ & & & \\
\hline $\begin{array}{l}1924-1928 \\
1929-1933\end{array}$ & $\begin{array}{l}\text { Cens th } \\
\text { Cons tha }\end{array}$ & $\begin{array}{ll}23^{\circ} & 38^{\prime} \\
23^{\circ} & 38^{\prime}\end{array}$ & $111^{\circ} 17^{\circ}$ & $\begin{array}{l}10.7 \\
10.7\end{array}$ & $120^{\circ}$ E.M.T & $\begin{array}{l}8(3,6,9,12, \\
15,18,21,24)\end{array}$ \\
\hline $\begin{array}{l}1934-1944 \\
1951.1-9\end{array}$ & $\begin{array}{l}\text { Cong the } \\
\text { No.B Bou At }\end{array}$ & $\left|\begin{array}{ll}23^{\circ} & 38^{\circ} \\
23^{\circ} & 30^{\circ}\end{array}\right|$ & $\begin{array}{ll}111^{\circ} & 17^{\prime} \\
111^{\circ} & 25^{\circ}\end{array}$ & $\begin{array}{l}10.7 \\
43.8\end{array}$ & $\begin{array}{l}120^{\circ} \text { E.M.T } \\
105^{\circ} \text { E.M.I }\end{array}$ & $\begin{array}{l}3(6,14,21) \\
16(6-21)\end{array}$ \\
\hline $1951.10-1952.10$ & $\begin{array}{l}\text { No. } 21 \text { weste- } \\
\text { In alley of } \\
\text { Woi } \mathrm{X} \text { in }\end{array}$ & $23^{*} 30^{*}$ & $111^{\circ} 25^{\circ}$ & 42.9 & 105' E.M.I & $\begin{array}{c}26(6-21) \\
.\end{array}$ \\
\hline $1952.11-12$ & $\begin{array}{l}\text { No. } 19 \text { ahu Ji } \\
\text { roed }\end{array}$ & $23^{\circ} 30^{\circ}$ & $111^{\circ} 25^{\circ}$ & 45.3 & $105^{\circ}$ E.M.I & $16(6-21)$ \\
\hline $\begin{array}{l}1953.1-12 \\
1954-1960.7\end{array}$ & $\begin{array}{l}\text { As above } \\
\text { Pans bill } \\
\text { top }\end{array}$ & $\left|\begin{array}{ll}23^{\circ} & 30^{\prime} \\
23^{\circ} & 29^{\prime}\end{array}\right|$ & $\mid \begin{array}{l}111^{\circ} \\
111^{\circ} \\
18\end{array}$ & $\begin{array}{l}43.0 \\
119.2\end{array}$ & $\begin{array}{l}105^{\circ} \text { E.M.T } \\
\text { Local mean } \\
\text { solar time }\end{array}$ & $\begin{array}{l}24(1-24) \\
4(1,7,13,19)\end{array}$ \\
\hline $1960.8-1983$ & As above & $23^{\circ} 29^{\circ}$ & $111^{\circ} 18^{\circ}$ & 119.2 & $\left|\begin{array}{r}\text { (Beiflang } \\
\text { timo) }\end{array}\right|$ & $4(2,8,14,20)$ \\
\hline
\end{tabular}

C. Number of Observations Used for Calculating the Daily Mean

\begin{tabular}{|c|c|c|c|}
\hline Mean timas & $\left|\begin{array}{c}\text { Men pressure } \\
\text { (Poriod) }\end{array}\right|$ & $\mid \begin{array}{r}\text { Temperatura } \\
\text { (Poriod) }\end{array}$ & $\mid \begin{array}{l}\text { Rolative } \\
\text { bumidity } \\
\text { (Pariod) }\end{array}$ \\
\hline $\begin{array}{r}(M a x+m i m+m i n d \\
m(m) / 2\end{array}$ & & & \\
\hline $3(6,14,21)$ & & $\begin{array}{l}1929-1933 \\
1934-1944\end{array}$ & $\begin{array}{l}1938.1-1943.10 \\
1944.1-8\end{array}$ \\
\hline $\begin{array}{l}24(1-24) \\
4(1,7,13,19) \\
4(2,8,14,20)\end{array}$ & $\begin{array}{l}1953.2-12 \\
1954-1960.7 \\
1960.8-1983\end{array}$ & $\begin{array}{l}1951-1953 \\
1954-1960.7 \\
1960.8-1983\end{array}$ & $\begin{array}{l}1951-1953 \\
1954-1960.7 \\
1960.8-1983\end{array}$ \\
\hline
\end{tabular}

D. Remacks :
1. O1d name: " Cang tong " 
A. Main Data Sources
i. $1908-1912$
(3)
1938-1943
2. $1912-1920$
3. 1912-1950
(14)
4. 1951-1960
(142)
5. $1961-1980$
(6) $(7)$
6. $1928-1936$
(15)
7. 1981-1983
8. 1963-1965 (cloud amount, dominant winds)
(13)(143)
(156)

B. Location of Station, I1me Standard and Iimes of Observations.

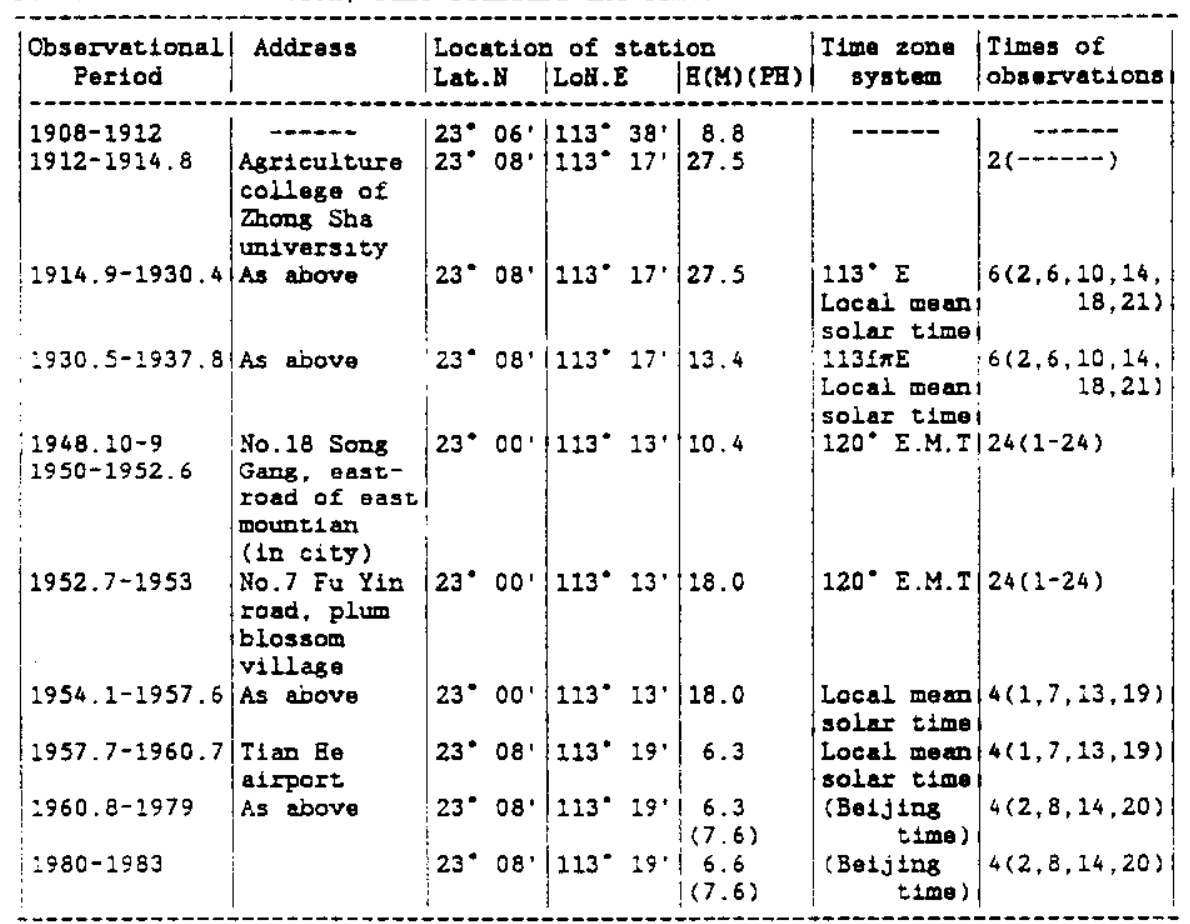

z. Number of Observations lised for Calculating the Daily Mean

\begin{tabular}{|c|c|c|c|}
\hline Yean times & $\begin{array}{c}\text { Mean pressure } \\
\text { (Period) }\end{array}$ & $\begin{array}{l}\text { Temperatura } \\
\text { (Eeriod) }\end{array}$ & $\begin{array}{l}\text { Relative } \\
\text { humidity } \\
\text { (Period) }\end{array}$ \\
\hline $\begin{array}{r}(\operatorname{Max} i \operatorname{man}(\operatorname{mini} \\
\tan ) / 2\end{array}$ & & $1924-1928$ & \\
\hline $6(2,6,10,14 ;$ & & $1929-1933$ & \\
\hline $\begin{array}{l}3(6,14,21) \\
24(1-24)\end{array}$ & $\begin{array}{l}1936-1937.8 \\
1948.10-1949.9 \\
1950-1953 \\
1930.5-1933\end{array}$ & $\begin{array}{l}1934-1937.8 \\
1948.10-1949.9 \\
1950-1953\end{array}$ & $\begin{array}{l}1948.10-1949.9 \\
1950-1953 \\
1912.2-1933\end{array}$ \\
\hline$\left\{\begin{array}{l}4(1,7,13,19) \\
4(2,8,14,20)\end{array}\right.$ & $\begin{array}{l}1954-1960.7 \\
1960.8-1983\end{array}$ & $\begin{array}{l}1954-1960.7 \\
1960.8-1983\end{array}$ & $\begin{array}{l}1954-1960.7 \\
1960.8-1983\end{array}$ \\
\hline
\end{tabular}

D. Remariks : 
A. Matn Data Sources
1. $1880-1943$
2. $1924-1942$
(2)(1)
3. $1928-1936$
4. $1951-1962$
(15)
5. $1963-1980$
6. $1981-1983$
(12) (144)
(6) (7) (8)(9)(10)(11)(143)
7. 1963-1965 (pressure, cloud anoumt and dominant winds (143)(13)

B. Location of Station, Time Standerd and Tfmes of Observations.

\begin{tabular}{|c|c|c|c|c|c|c|}
\hline $\begin{array}{l}\text { Observetional } \\
\text { Period }\end{array}$ & Addros: & $\mid \begin{array}{l}\text { Locatiog } \\
\text { Lat. } 8\end{array}$ & $\begin{array}{l}\text { a of stats } \\
\mid \text { Lod. }\end{array}$ & $\begin{array}{l}\operatorname{lon} \\
|\mathrm{B}(\mathrm{M})(\mathrm{PB})|\end{array}$ & $\left|\begin{array}{c}\text { TIme zono } \\
\text { systex }\end{array}\right|$ & $\left|\begin{array}{l}\text { Times of } \\
\text { observations }\end{array}\right|$ \\
\hline $1880-1923$ & $\left\{\begin{array}{l}\text { Custmos sta- } \\
\text { t10n }\end{array}\right.$ & $23^{\circ} 21^{\prime}$ & $\left|116^{\circ} 40^{\circ}\right|$ & 3.4 & $\mid 120^{\circ}$ E.M.T $\mid$ & \\
\hline $1924-1928$ & As above & $23^{\circ} 21^{\circ}$ & $116^{\circ} 40^{\prime}$ & 3.4 & $120^{\circ}$ E.M.I & $\left|\begin{array}{r}2 \text { (Meximumini } \\
n \leq \mathrm{smm})\end{array}\right|$ \\
\hline $1929-1933$ & As above & $23^{\circ} 21^{\prime}$ & $126^{\circ} 40^{\circ}$ & 3.4 & $120^{\circ}$ E.M.T & $\begin{array}{l}8(3,6,9,12 \\
15,18,21,24)\end{array}$ \\
\hline $\begin{array}{l}1934-1938.10 \\
1938.10-1942 \\
1951-1952.5\end{array}$ & $\begin{array}{l}\text { As above } \\
\text { As above } \\
\text { No.311 WaiMa } \\
\text { soad in ctty }\end{array}$ & $\mid \begin{array}{ll}23^{\circ} & 21^{\prime} \\
23^{\circ} & 21^{\prime} \\
23^{\circ} & 20^{\prime}\end{array}$ & $\left|\begin{array}{ll}116^{\circ} & 40^{\circ} \\
116^{\circ} & 40^{\circ} \\
116^{\circ} & 40^{\circ}\end{array}\right|$ & $\begin{array}{l}3.4 \\
3.4 \\
2.2\end{array}$ & $\left|\begin{array}{ll}120^{\circ} & \text { E.M.I } \\
120^{\circ} & \text { E.M.I } \\
120^{\circ} & \text { E.M.I }\end{array}\right|$ & $\begin{array}{l}3(6,14,21) \\
24(1-24)\end{array}$ \\
\hline $\begin{array}{l}1952.6-1953.12 \\
1954-1955.9\end{array}$ & As above & $\mid \begin{array}{ll}23^{*} & 21^{\prime} \\
23^{*} & 21^{\circ}\end{array}$ & $\left|\begin{array}{ll}116^{\circ} & 40 \\
116^{\circ} & 40^{\circ}\end{array}\right|$ & $\begin{array}{l}5.3 \\
5.3\end{array}$ & $\mid \begin{array}{ll}120^{\circ} & \text { Z.H.T } \\
\text { Local } & \text { meen } \\
\text { soliar time }\end{array}$ & $\mid \begin{array}{l}24(1-24) \\
4(1,7,13,19)\end{array}$ \\
\hline $1955.9-1960.7$ & $\begin{array}{l}\text { Near the Ko- } \\
\text { ng religtom } \\
\text { temple (sub- } \\
\text { urb) }\end{array}$ & $23^{\circ} 21^{\prime}$ & $116^{\circ} 40^{\prime}$ & 5.3 & Local moln & $4(1,7,23,19)$ \\
\hline $1960.8-1965$ & As sbove & $23^{\circ} 21^{\prime}$ & $116^{\circ} 40^{\circ}$ & 4.3 & $\begin{array}{c}\text { (Beijing } \\
\text { time) }\end{array}$ & $4(2,8,14,20)$ \\
\hline $1966-1983$ & As above & $23^{\circ} 24^{\prime}$ & $116^{\circ} 41^{\prime}$ & $\begin{array}{c}1.2 \\
(3.5)\end{array}$ & $\left|\begin{array}{c}(B \cdot 1 j \operatorname{ses} \\
\text { timo })\end{array}\right|$ & $4(2,8,14,20)$ \\
\hline
\end{tabular}

C. Number of Observations Usod for Calculatins the Daily Moan

\begin{tabular}{|c|c|c|c|c|}
\hline Moan times & $\mid \begin{array}{c}\text { Moen pressure } \\
\text { (Fertod) }\end{array}$ & $\begin{array}{l}\text { Temperature } \\
\text { (Period) }\end{array}$ & $\begin{array}{l}\text { Relative } \\
\text { humidity } \\
\text { (Period) }\end{array}$ & $\begin{array}{l}\text { Wind } \\
\text { (Pertod) }\end{array}$ \\
\hline $\begin{array}{l}\text { (Maximmint } \\
8(3,6,9,12,15 \\
18,21,24) \\
3(6,14,21) \\
24(1-24) \\
4(1,7,13,19) \\
4(2,8,14,20)\end{array}$ & $\begin{array}{l}1951-1953 \\
1954-1960.7 \\
1960.8-1983\end{array}$ & $\begin{array}{l}1924-1928 \\
1929-1933 \\
1934-1938.10 \\
1938.10-1942 \\
1951-1953 \\
1954-1960.7 \\
1960.8-1983\end{array}$ & $\begin{array}{l}1950(7-12) \\
1951-1953 \\
1954-1960.7 \\
1960.8-1983\end{array}$ & $\begin{array}{l}1952-1953 \\
1954-1960.7 \\
1960.8-1983\end{array}$ \\
\hline
\end{tabular}

D. Remarks : 
No. 5859431 Nan Ning

A. Main Data Sources
1. $1907.9-1950$
2. $1935-1950$
3. $1922-1950$
4. $1946-1950$
5. $1951-1960$
6. $1961-1970$
7. $1971-1980$
8. $1981-1983$
9. 1961-1970 (mean/max/min temperatura
and cloud amount) (157)
10. 1935-1936 (pressure, cloud amount, and winds)
(145)
(4)
(147)
(12)
(149)
(149)
(13)
(157)

B. Location of Station. Time Standard and Times of Observations.

\begin{tabular}{|c|c|c|c|c|c|c|}
\hline $\begin{array}{c}\text { Observat lonal } \\
\text { Pertod }\end{array}$ & Address & $\left|\begin{array}{l}\text { Locat1on } \\
\text { Lat.N }\end{array}\right|$ & $\begin{array}{l}\text { mof of stat } \\
\text { |LoN.E }\end{array}$ & | 100 & $\begin{array}{c}\text { Time zone } \\
\text { system }\end{array}$ & \begin{tabular}{|l|} 
Times of \\
observations
\end{tabular} \\
\hline $1907-1949$ & $\begin{array}{l}\text { Hgdrologic } \\
\text { station }\end{array}$ & $22^{\circ} 48^{\prime} \mid$ & $108^{\circ} 22^{\circ}$ & & & \\
\hline $1922-1939$ & $\begin{array}{l}\text { Climatologi- } \\
\text { cal observa- } \\
\text { tion statton }\end{array}$ & $22^{\circ} 42^{\circ}$ & $108^{\circ} 16^{\circ}$ & $\begin{array}{l}76.0 \\
(76.7)\end{array}$ & $22^{\circ}$ E.M.T & $3(6,14,21)$ \\
\hline$: 946-1950.5$ & & $22^{\circ} 42^{\prime}$ & $108^{\circ} 16^{\prime}$ & $\begin{array}{c}76.0 \\
(76.7)\end{array}$ & $105^{\circ}$ E.M.T & $\mid 3(6,14,21)$ \\
\hline $\begin{array}{l}: 950.6-1953 \\
: 954.1-1956.8\end{array}$ & & $\begin{array}{ll}22^{\circ} & 48^{\prime} \\
22^{\circ} & 48^{\prime}\end{array}$ & $\begin{cases}108^{\circ} & 18^{\prime} \\
108^{\circ} & 18^{\prime}\end{cases}$ & $\begin{array}{l}74.0 \\
74.9\end{array}$ & $\begin{array}{l}105^{\circ} \text { E.M.T } \\
\text { Local maan } \\
\text { solar time }\end{array}$ & $\begin{array}{l}24(1-24) \\
4(1,7,13,19)\end{array}$ \\
\hline $1956.9-1960.7$ & & $22^{\circ} 51^{\prime}$ & $108^{\circ} 19^{\circ}$ & 122.3 & $\begin{array}{l}\text { Local mean } \\
\text { solar t1me }\end{array}$ & $4(1,7,13,19)$ \\
\hline $1960.8-1965.9$ & & $22^{\circ} 49^{\circ}$ & $108^{\circ} 21^{\circ}$ & 122.3 & $\begin{array}{c}\text { (Beijing } \\
\text { time })\end{array}$ & $4(2,8,14,20)$ \\
\hline $1965.10-1983$ & & $22^{\circ} 49^{\circ}$ & $108^{\circ} 21^{\circ}$ & 72.2 & $\left(\begin{array}{c}\text { (Beijing } \\
\text { Eime) }\end{array}\right.$ & $4(2,8,14,20)$ \\
\hline
\end{tabular}

C. Number of Observations Used for Calculating the Dally Mean

\begin{tabular}{|l|l|l|l|}
\hline Mean times & $\begin{array}{l}\text { Mean pressure } \\
\text { (Pertod) }\end{array}$ & $\begin{array}{l}\text { Temperature } \\
\text { (Pertod) }\end{array}$ & $\begin{array}{l}\text { Relative } \\
\text { humidity } \\
\text { (Pertod) }\end{array}$ \\
\hline $3(6,14,21)$ & & $\begin{array}{l}1922-1935.6 \\
1946-1949 \\
1937-1939\end{array}$ & $1935-1944$ \\
& & $1950-1953$ & $1950-1953$ \\
$24(1-24)$ & $1950-1953$ & $1950.5-6$ \\
$4(2,7,13,29)$ & $1954-1960.7$ & $1954-1960.7$ & $1954-1960.7$ \\
$4(2.8 .14 .20)$ & $1960.8-1983$ & $1960.8-1983$ & $1960.8-1983$ \\
\hline
\end{tabular}

D. Remarks :

¿. Old name: "Yong Ning " 
A. Main Data Sources
1. $1913-1953$
(156)
2. $1931-1940$
(151)
3. $1951-1960$
(152)
4. $1961-1980$
5. $1981-1983$
6. 1963-1965 (pressure, cloud abount, dominant winds)
$(143)(6)(7)(8)(9)(10)(11)$
(13) (143)
(156)

8. Location of Station, IIme Standard and Times of Observations.

\begin{tabular}{|c|c|c|c|c|c|c|}
\hline $\begin{array}{l}\text { Observational } \\
\text { Pertod }\end{array}$ & Addrass & $\left|\begin{array}{l}\text { Locatior } \\
\text { Lat. } \mathrm{B}\end{array}\right|$ & $\begin{array}{l}\text { p of stat: } \\
\text { Loll.E }\end{array}$ & $\begin{array}{l}102 \\
\mathrm{H}(\mathrm{M})(\mathrm{FH})\end{array}$ & $\mid \begin{array}{c}\text { Tlmo zone } \\
\text { system }\end{array}$ & $\mid \begin{array}{l}\text { Times of } \\
\text { observations }\end{array}$ \\
\hline $1913-1936$ & Custmos ste- & $21^{\circ} 05^{\prime}$ & $110^{\circ} 25^{\circ}$ & 24.0 & & \\
\hline $\begin{array}{l}1921-1936 \\
1936-1940 \\
1950.6-1953\end{array}$ & $\begin{array}{l}\text { As bove } \\
\text { No.1 Min You }\end{array}$ & $\begin{array}{ll}21^{\circ} & 03^{\prime} \\
21^{\circ} & 03^{\circ} \\
21^{\circ} & 02^{\prime}\end{array}$ & $\begin{array}{l}110^{\circ} 35^{\prime} \\
110^{\circ} 28 \\
110^{\circ} \\
28^{\prime}\end{array}$ & $\begin{array}{l}14.0 \\
14.0 \\
10.0\end{array}$ & $\begin{array}{ll}105^{\circ} & \text { E.M.T.T } \\
120^{\circ} & \text { E.M.T }\end{array}$ & $\begin{array}{l}3(3,7,13) \\
24(1-24)\end{array}$ \\
\hline $1954.1-10$ & $\begin{array}{l}\text { Ioad in city } \\
\text { As above }\end{array}$ & $21^{\circ} 02^{\prime}$ & $110^{\circ} 28^{\prime}$ & 10.0 & Local mean & $4(1,7,13,19)$ \\
\hline $1954.11-1960.7$ & $\begin{array}{l}\text { X1a Shen Egs } \\
\text { mountian ra- } \\
\text { rge (countr- } \\
\text { Yetde) }\end{array}$ & $21^{\circ} 02^{\prime}$ & $110^{\circ} 28^{\circ}$ & 26.4 & 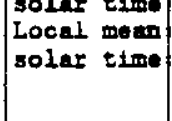 & $4(1,7,13,19)$ \\
\hline $1960.8-1973$ & As ibove & $21^{\circ} 02^{\prime}$ & $110^{\circ} 28^{\circ}$ & 26.4 & (Be1j1ng & $4(2,8,14,20)$ \\
\hline $1974-1978$ & & $21^{*} 23^{\prime}$ & $110^{\circ} 24^{\circ}$ & 25.1 & (Be1j108 & $4(2,8,14,20)$ \\
\hline 1979-1983 & & $21^{\circ} 13^{\prime}$ & $110^{\circ} 24^{\circ}$ & 25.3 & $\begin{array}{r}\text { (Boiftzs } \\
\text { timo) }\end{array}$ & $4(2,8,14,20)$ \\
\hline
\end{tabular}

C. Number of Observations Used for Calculating the Dally Mean

\begin{tabular}{|c|c|c|c|c|}
\hline Mean tioes & $\begin{array}{c}\text { Meen pressure } \\
\text { (Perlod) }\end{array}$ & $\mid \begin{array}{r}\text { Temperature } \\
\text { (Pertod) }\end{array}$ & $\mid \begin{array}{l}\text { Relattve } \\
\text { humid1ty } \\
\text { (Period) }\end{array}$ & $\begin{array}{l}\text { Wind } \\
\text { (Period) }\end{array}$ \\
\hline $\begin{array}{l}\text { (Maxtmint } \\
3(6,14,21) \\
24(1-24) \\
4(1,7,13,19) \\
4(2,8,14,20)\end{array}$ & $\begin{array}{l}1953.8-12 \\
1954-1960.7 \\
1960.8-1983\end{array}$ & $\begin{array}{l}1921-1936 \\
1950.6-12 \\
1951-1953 \\
1954-1960.7 \\
1960.8-1983\end{array}$ & $\begin{array}{l}1950.6-12 \\
1951-1953 \\
1954-1960.7 \\
1960.8-1983\end{array}$ & $\begin{array}{l}1951-1953 \\
1954-1960.7 \\
1960.8-1983\end{array}$ \\
\hline
\end{tabular}

D. Remarixs : 
A. Main Data Sources

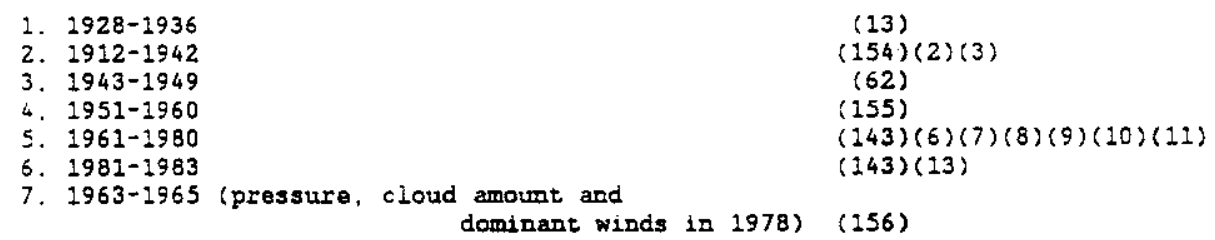

B. Location of Station, T1me Standard and Times of Observations.

\begin{tabular}{|c|c|c|c|c|c|c|}
\hline $\begin{array}{c}\text { Observational } \\
\text { Pertod }\end{array}$ & Address & $\begin{array}{l}\text { Locattor } \\
\text { Lat.N }\end{array}$ & $\begin{array}{l}\text { a of stats } \\
\text { |LoN.E }\end{array}$ & ton & $\mid \begin{array}{c}\text { Time zone } \\
\text { system }\end{array}$ & $\begin{array}{l}\text { Times of } \\
\text { observations }\end{array}$ \\
\hline $\begin{array}{l}1912-1923 \\
1924-1928\end{array}$ & $\begin{array}{l}\text { Qong mountian } \\
\text { Qong mounttan }\end{array}$ & $\left|\begin{array}{ll}20^{\circ} & 01 \\
20^{\circ} & 01\end{array}\right|$ & $\left|\begin{array}{ll}110^{\circ} & 16^{\prime} \\
110^{\circ} & 16^{\prime}\end{array}\right|$ & $\begin{array}{l}2.7 \\
2.7\end{array}$ & $\begin{array}{l}105^{\circ} \text { E.M.T } \\
105^{\circ} \text { E.M.T }\end{array}$ & 2 (Maximumant \\
\hline $2929-1933$ & Qons mounttan & $20^{\circ} 01^{\prime}$ & $110^{\circ} 16^{\circ}$ & 2.7 & $105^{*}$ E.M.I & $\begin{array}{l}8(3,6,9,12 \\
15,18,21,24)\end{array}$ \\
\hline $\begin{array}{l}1934- \\
2951.1-1953.4 \\
2953.5-7\end{array}$ & $\begin{array}{l}\text { Qong mountian } \\
\text { Airport } \\
\text { Hai Kou airp- } \\
\text { ort }\end{array}$ & $\mid \begin{array}{ll}20^{\circ} & 01^{\prime} \\
20^{\circ} & 00^{\prime} \\
20^{\circ} & 00^{\circ}\end{array}$ & 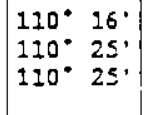 & $\begin{array}{r}2.7 \\
16.2 \\
16.2\end{array}$ & $\begin{array}{l}105^{\circ} \text { E.M.T } \\
: 20^{\circ} \text { E.M.T } \\
220^{\circ} \text { E.M.T }\end{array}$ & $\begin{array}{l}3(6,14,21) \\
24(1-24) \\
24(1-24)\end{array}$ \\
\hline $1953.8-12$ & $\begin{array}{l}\text { No. } 2 \text { Wen Ming } \\
\text { oast road } \\
\text { (suburb) }\end{array}$ & $23^{\circ} 30^{\circ}$ & $110^{\circ} 25^{\prime}$ & 2.8 & $220^{\circ}$ E.M.I & $24(1-24)$ \\
\hline $2954-1957.4$ & $\begin{array}{l}\text { Long Ji vill- } \\
\text { age of Zilong } \\
\text { town third } \\
\text { district (co- } \\
\text { untryside) }\end{array}$ & $20^{\circ} 00^{\circ}$ & $110^{\circ} 25^{\prime}$ & 24.4 & $\begin{array}{l}\text { Local mean } \\
\text { solar time }\end{array}$ & $4(1,7,13,19)$ \\
\hline $1957.5-1960.7$ & As above & $20^{\circ} 00^{\circ}$ & $110^{\circ} 25^{\prime}$ & 14.1 & $\begin{array}{l}\text { Local mean } \\
\text { solar teme }\end{array}$ & $4(1,7,13,19)$ \\
\hline $1960.8-1968$ & $\begin{array}{l}\text { Fu Cheng town } \\
\text { Qons mountian } \\
\text { coumty (coun- } \\
\text { trystde) }\end{array}$ & $20^{\circ} 01^{\prime}$ & $120^{\circ} 21^{\circ}$ & 17.6 & (Baijing & $4(2,8,14,20)$ \\
\hline $1969-1983$ & As above & $20^{\circ} 02^{\circ}$ & $110^{\circ} 2:^{\prime}$ & 14.1 & $\begin{array}{c}\text { (Boljing } \\
\text { time) }\end{array}$ & $4(2,8,14,20)$ \\
\hline
\end{tabular}

c. Number of Observations Used for Calculating the Daily Mean

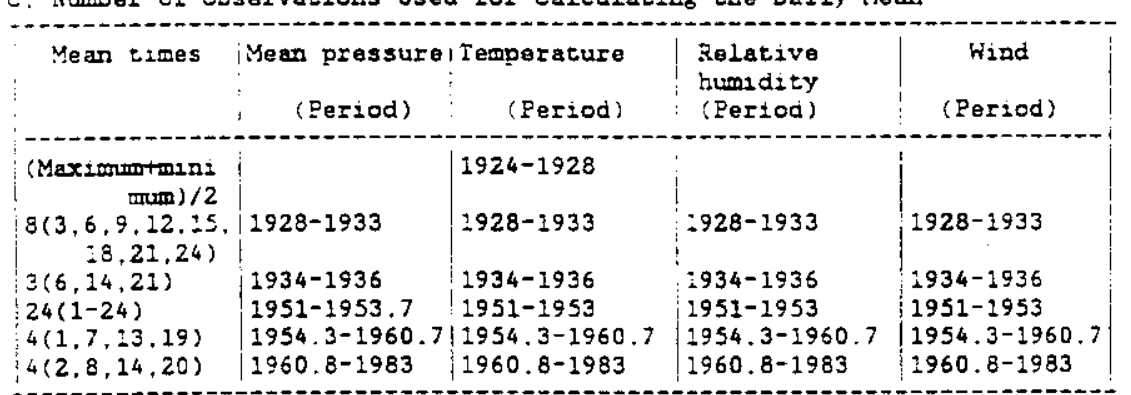

\section{Remariks :}

$\therefore$ Old name: "Qong mountain" 


\section{APPENDIX C}

SOURCES OF DATA FOR THE PRC 60STATION CLMMATE DATA SET 


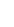




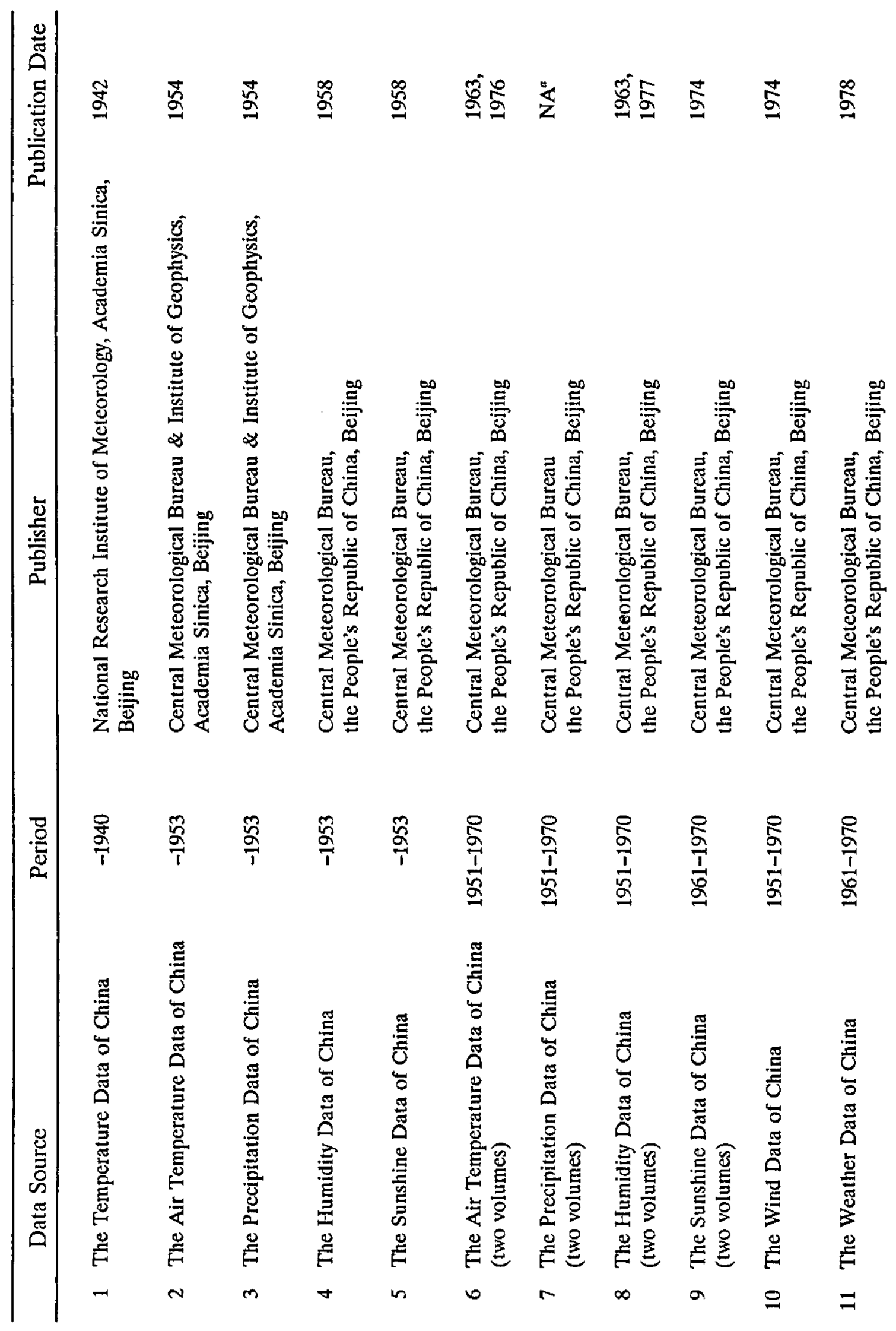


C- 4

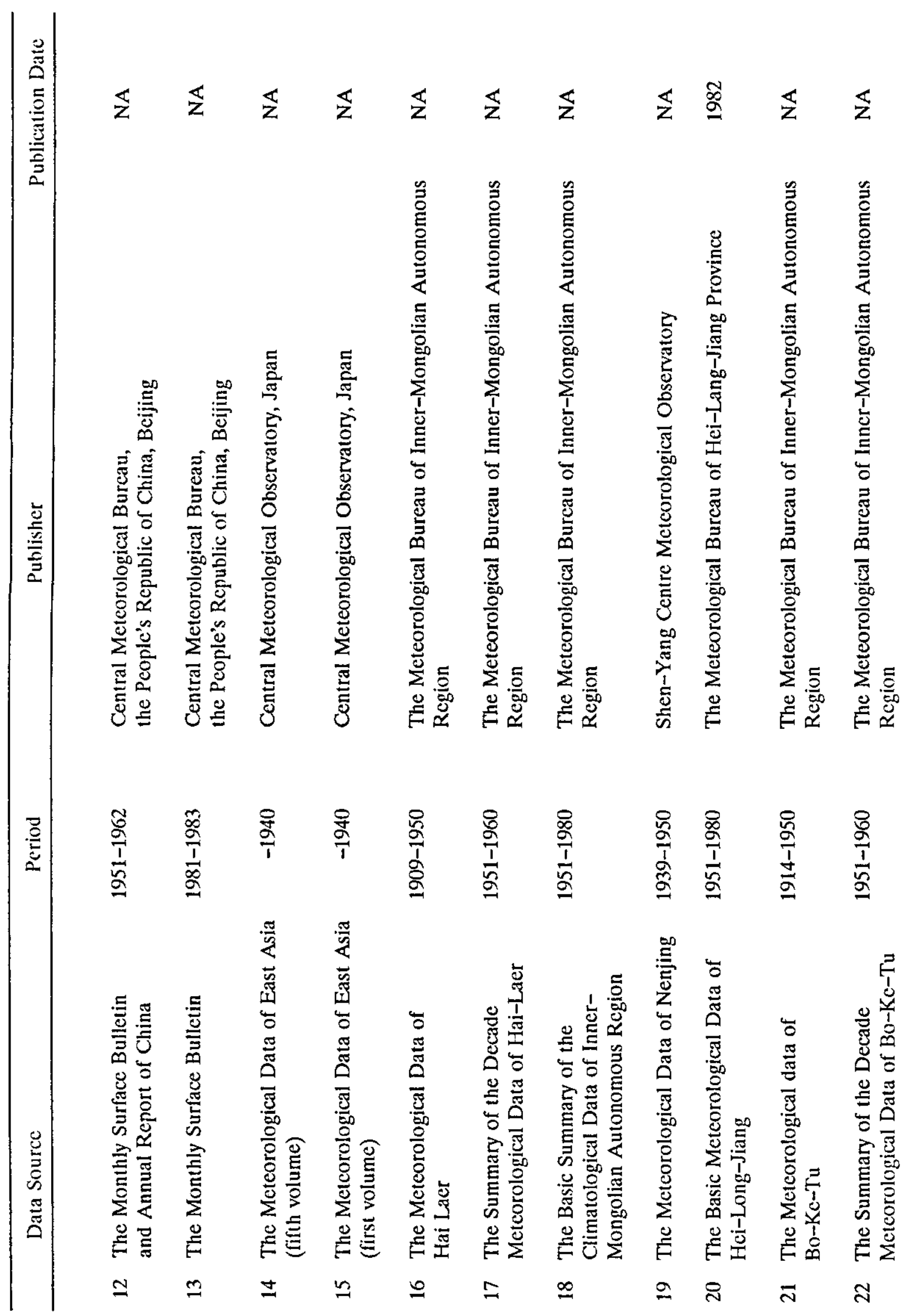


C-5

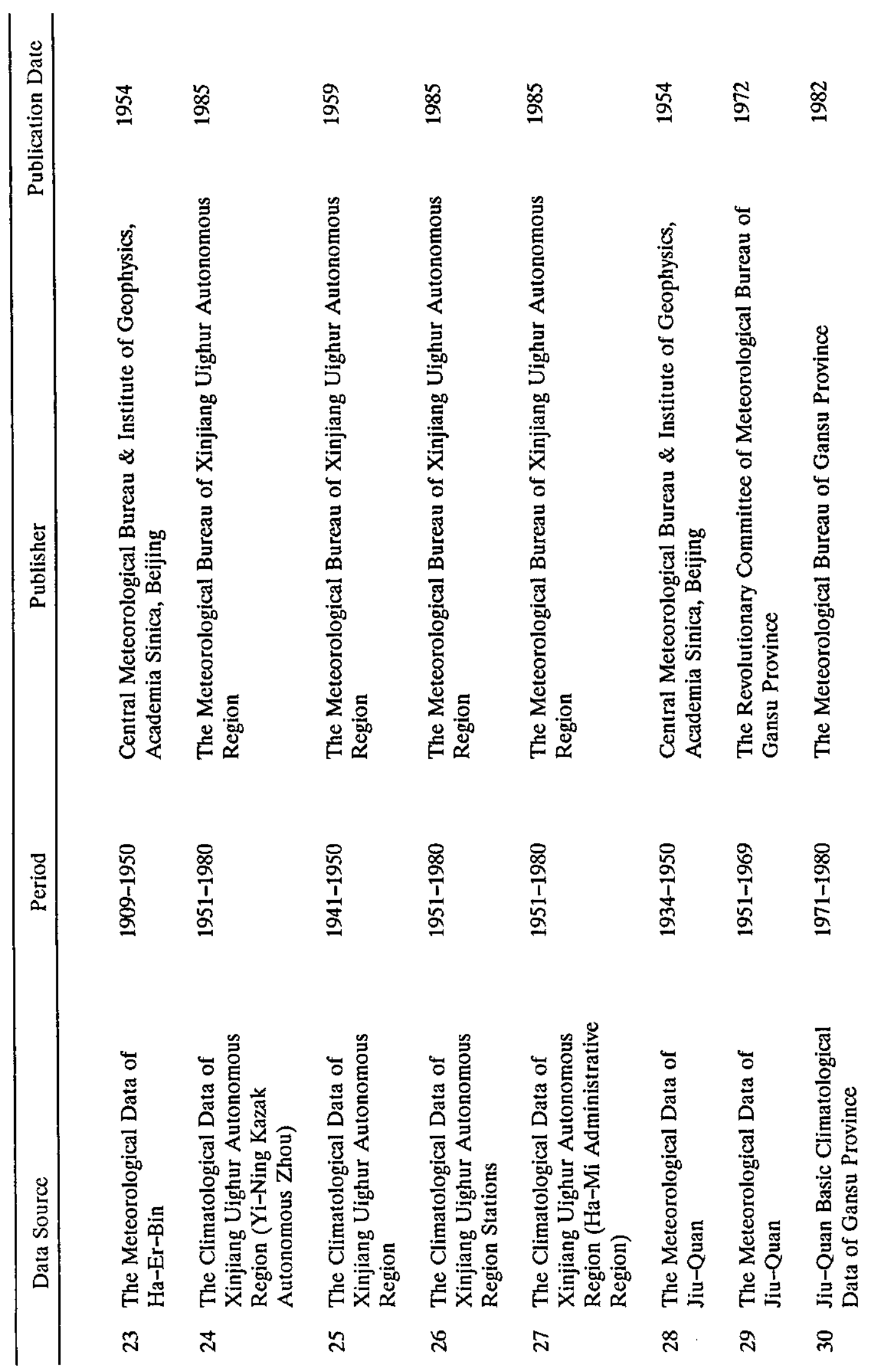




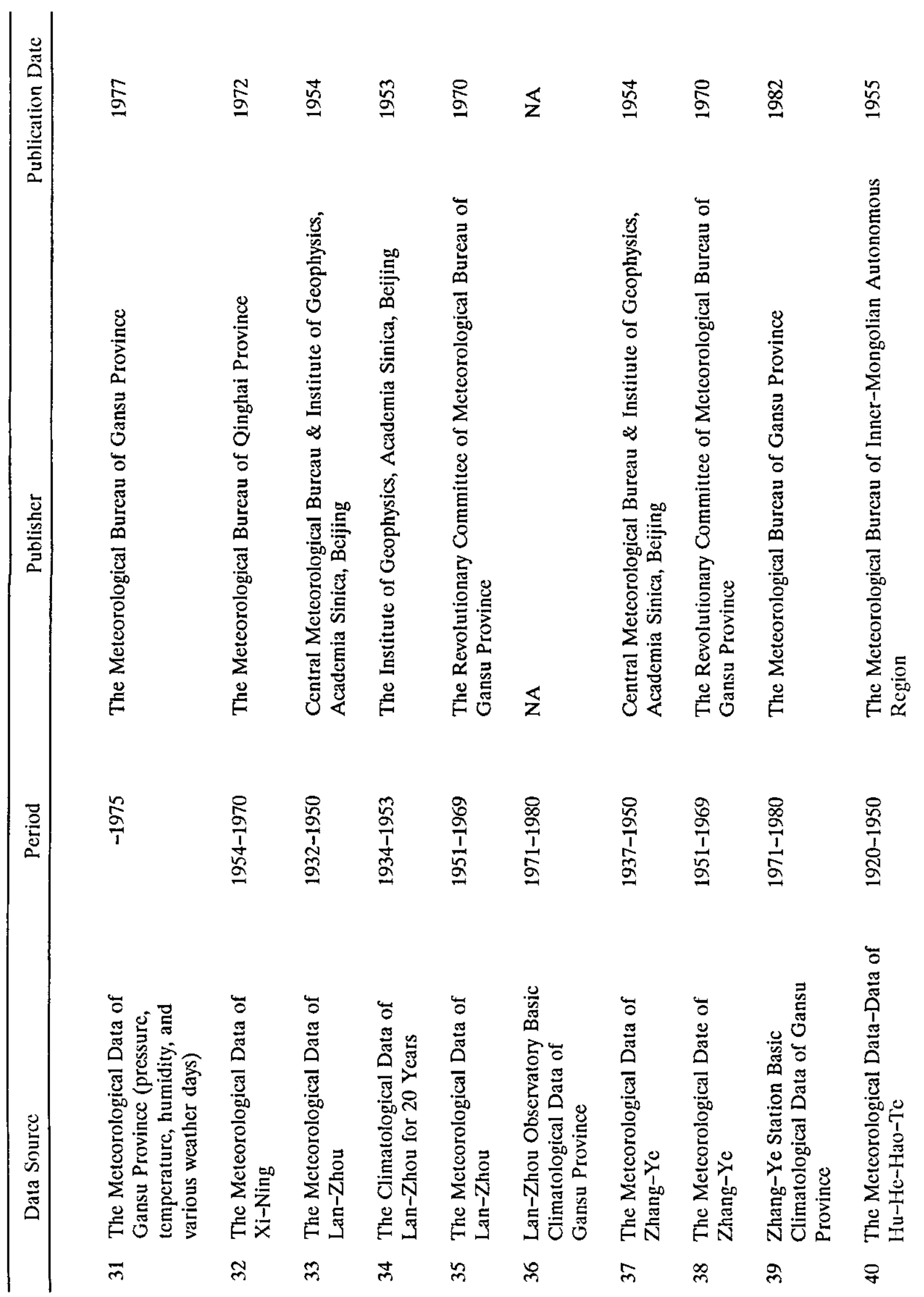




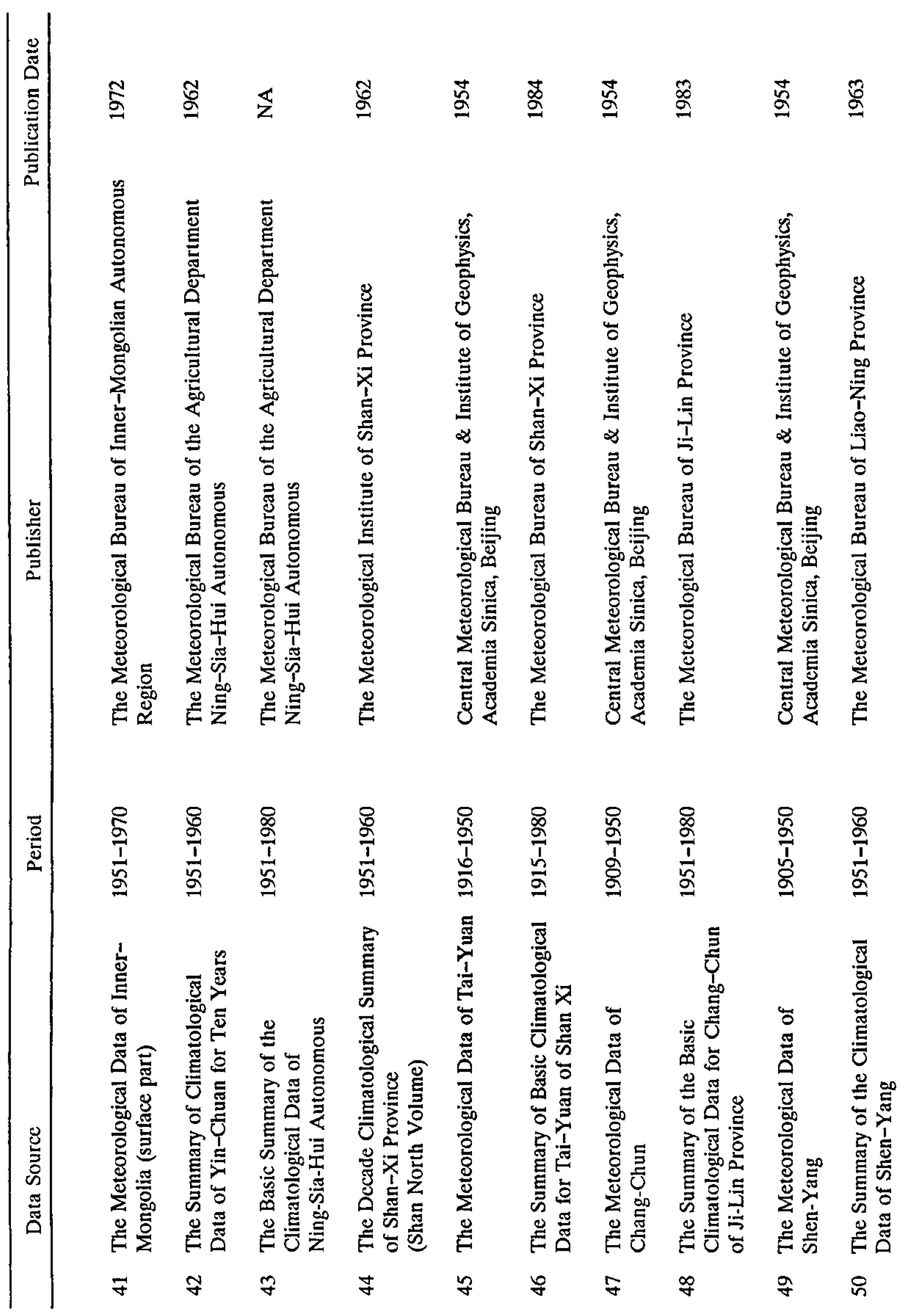




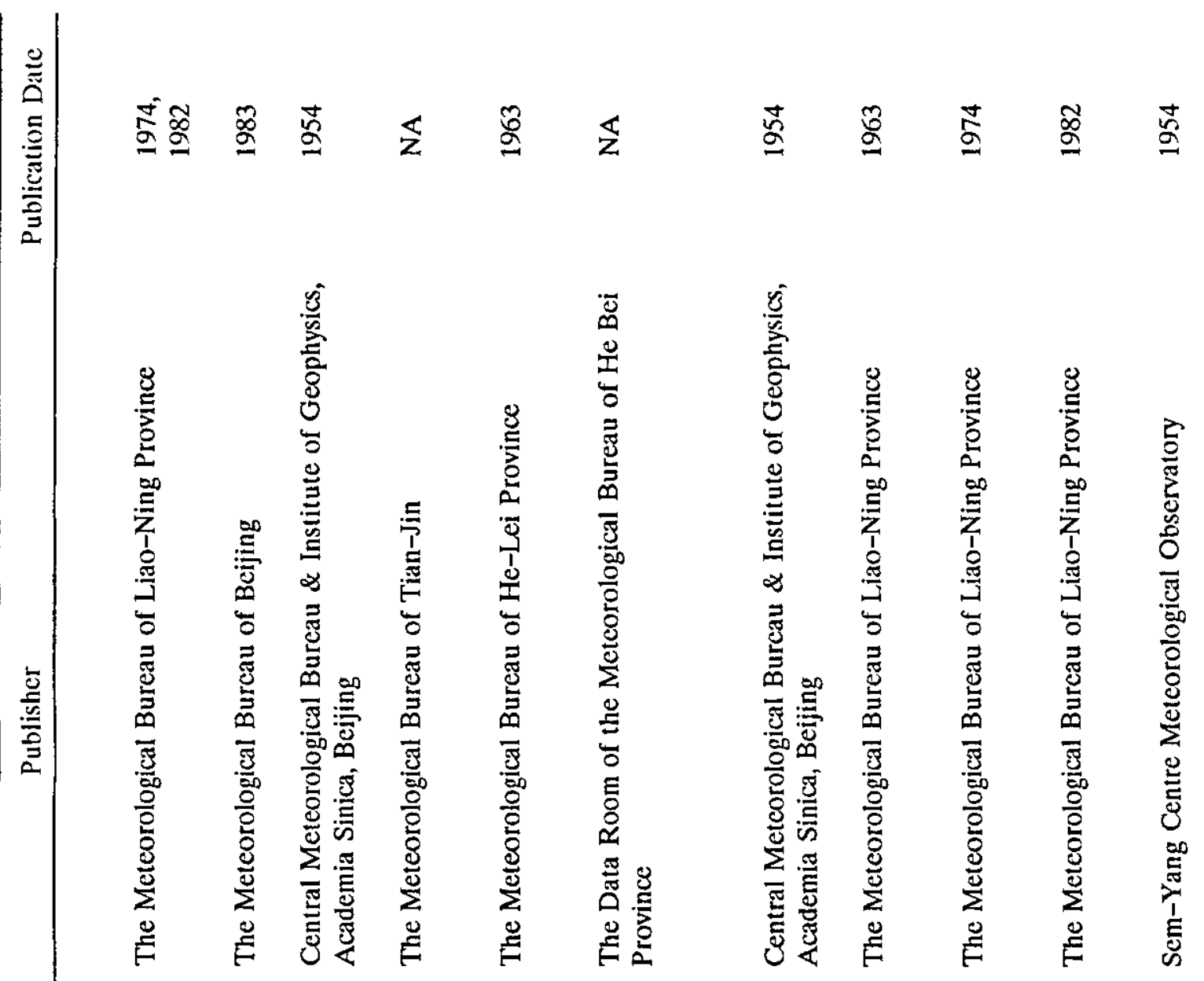

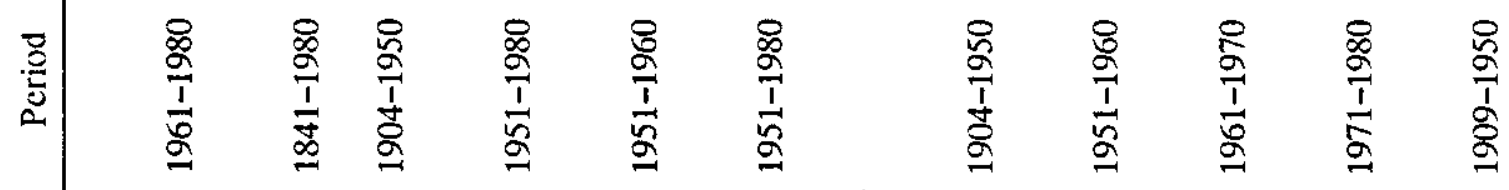

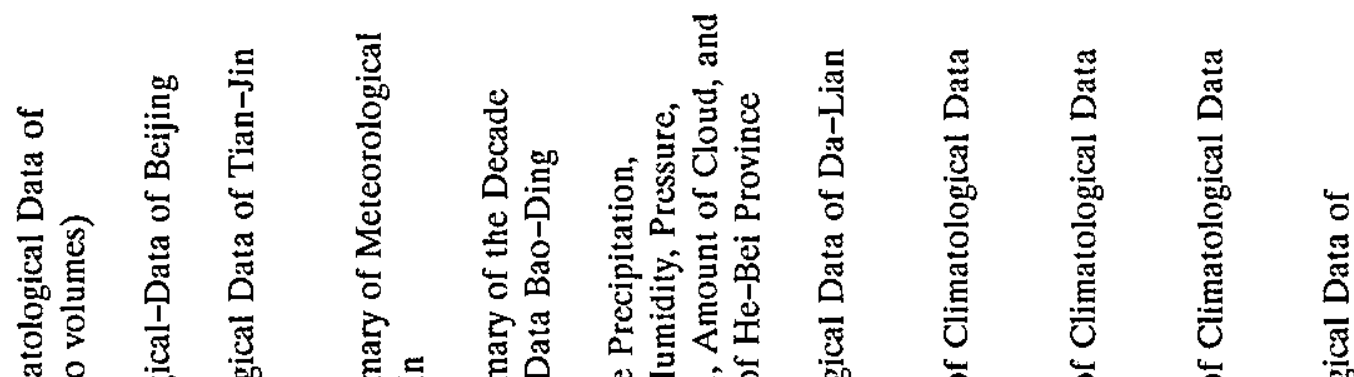

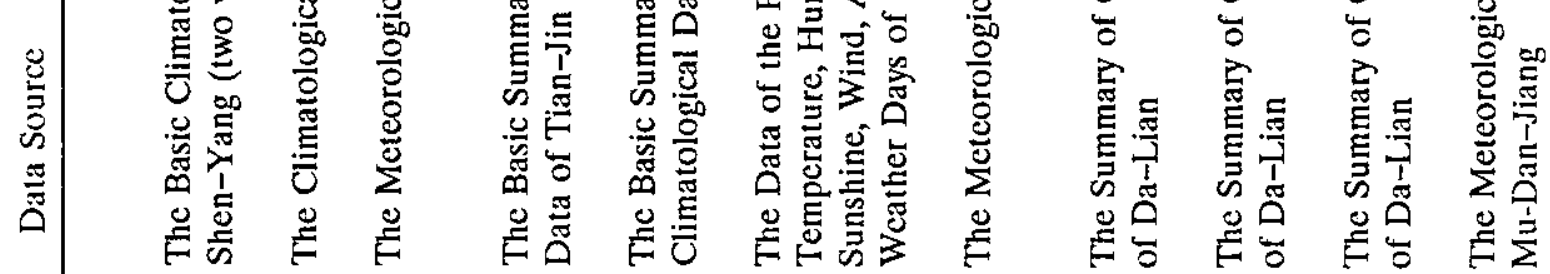

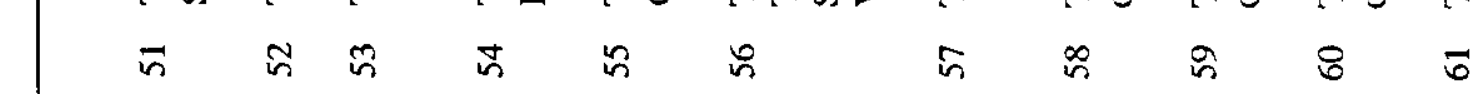




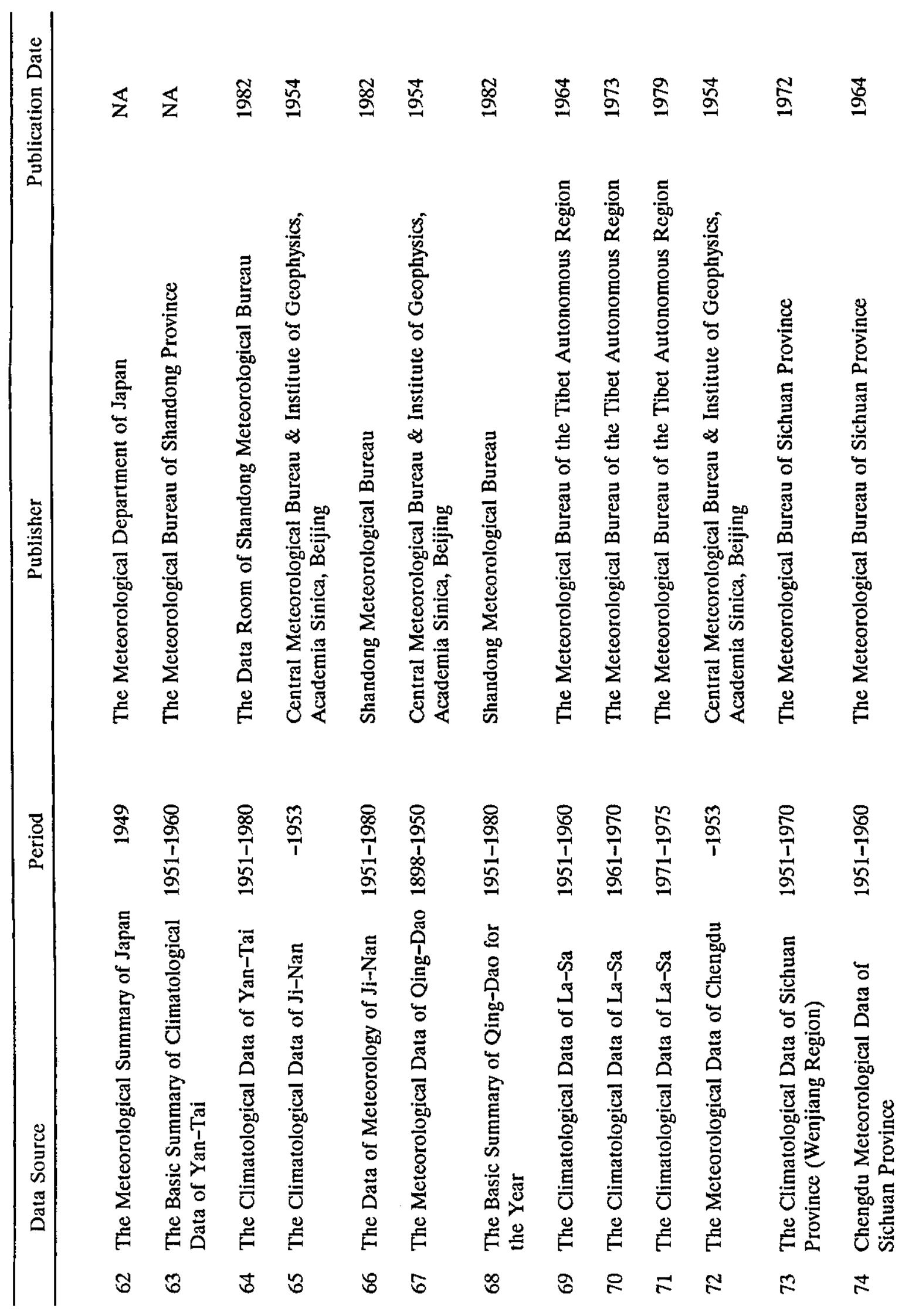




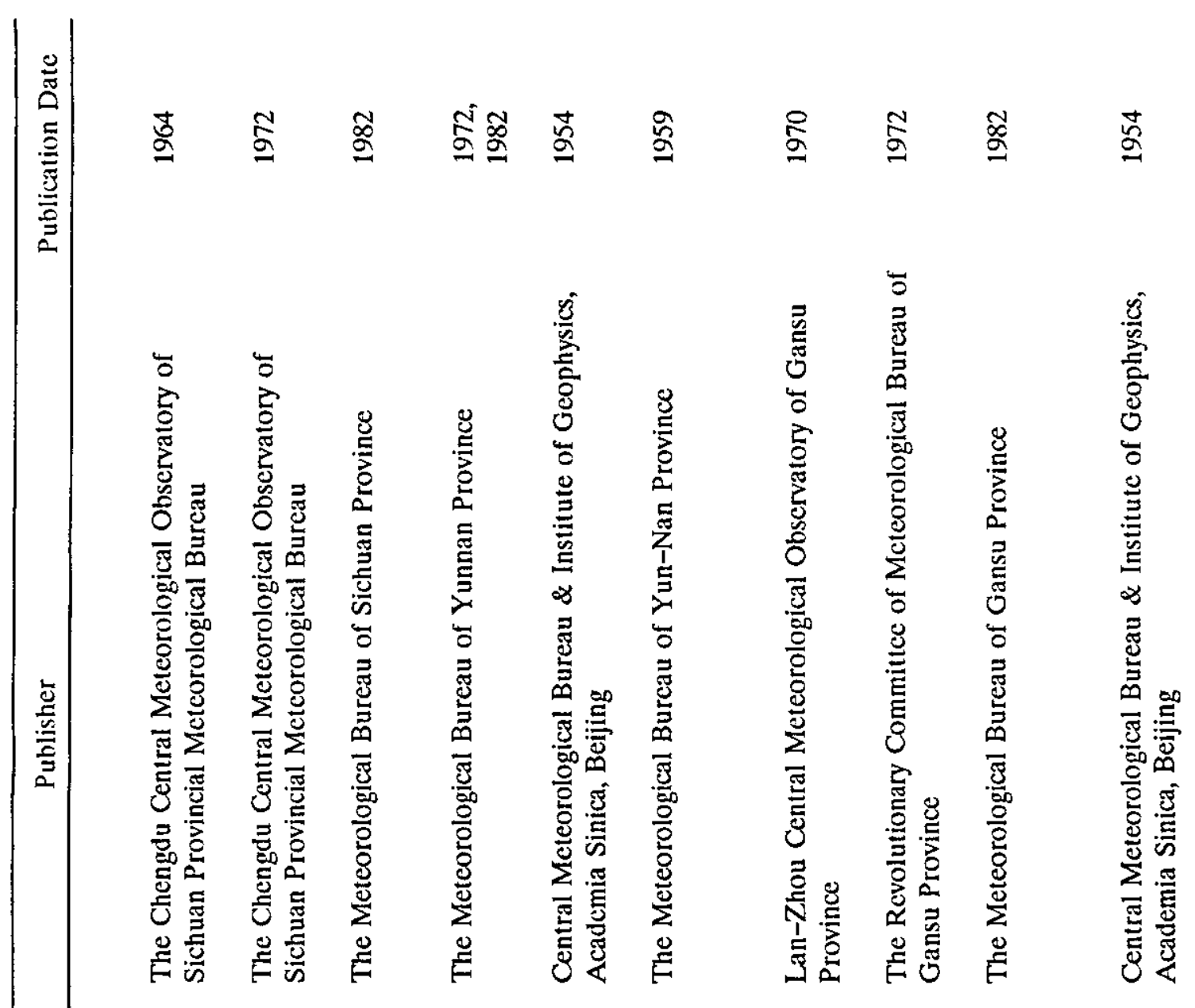

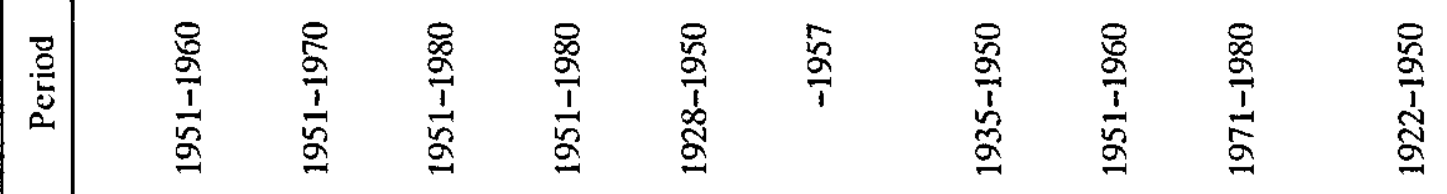

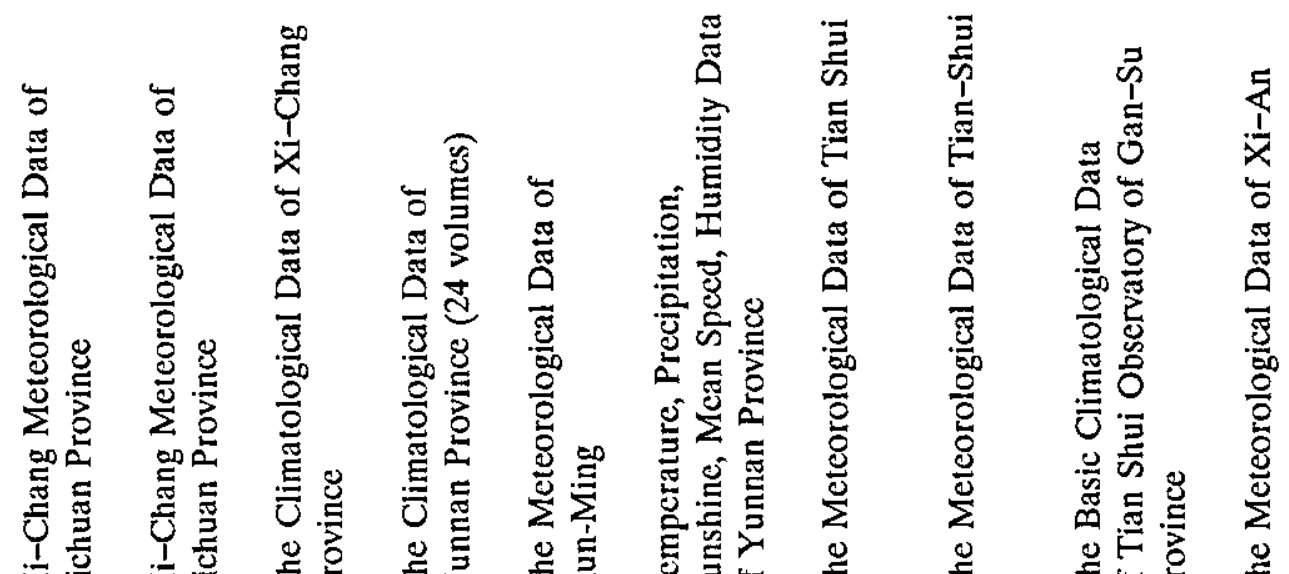

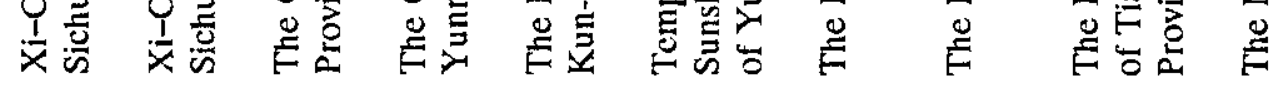

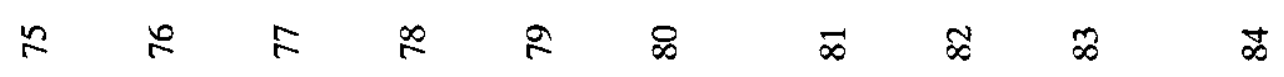




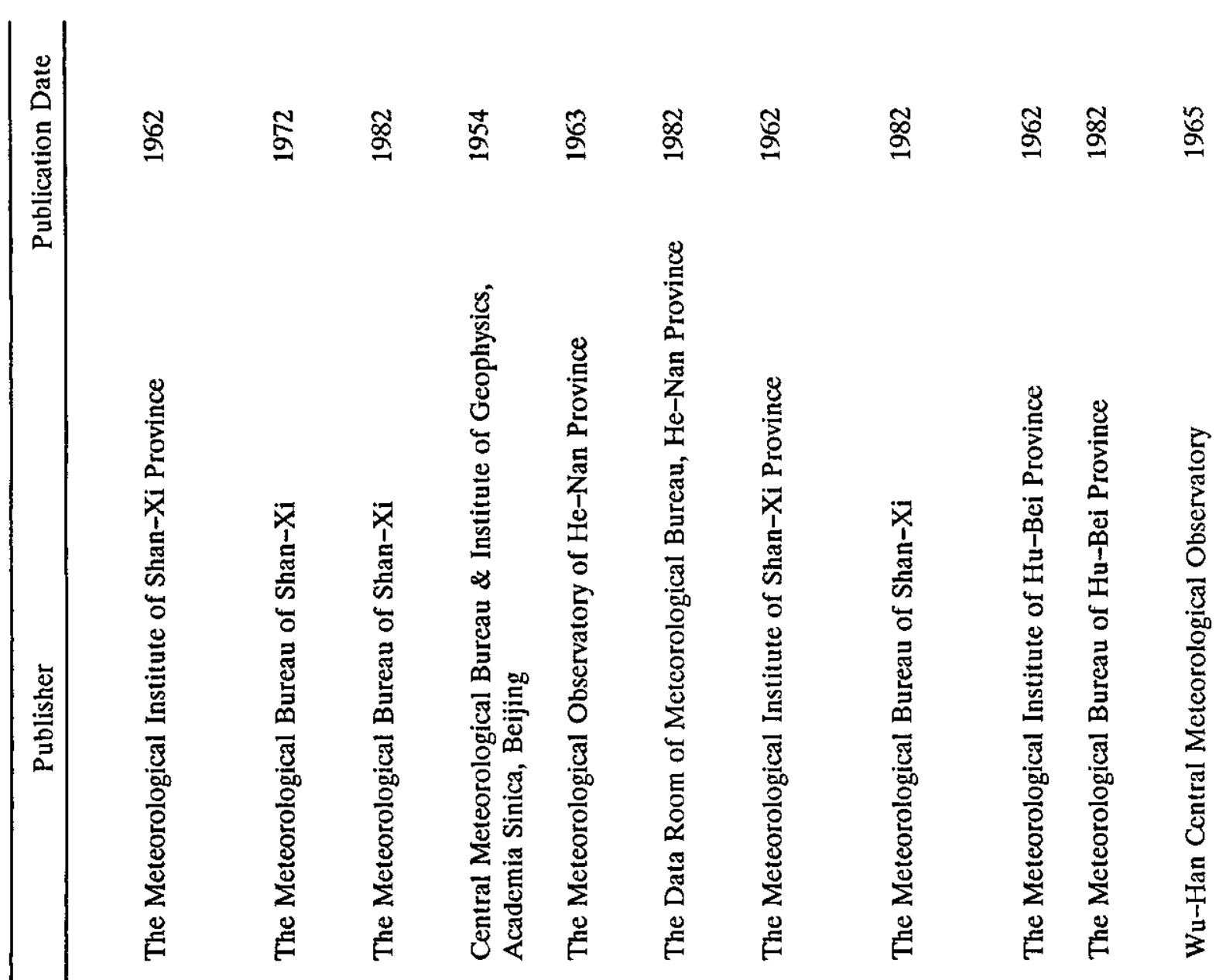

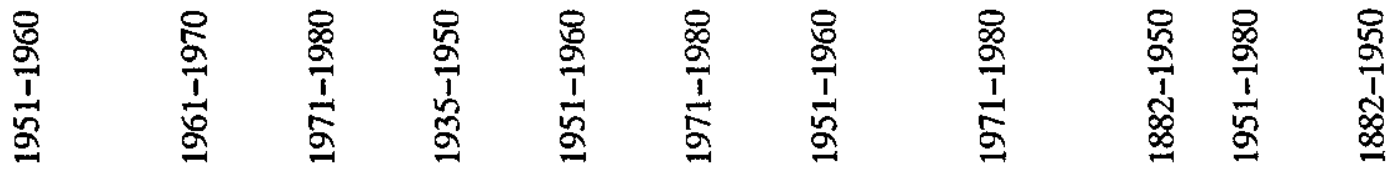

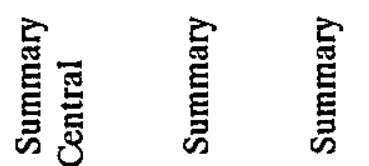

उึ

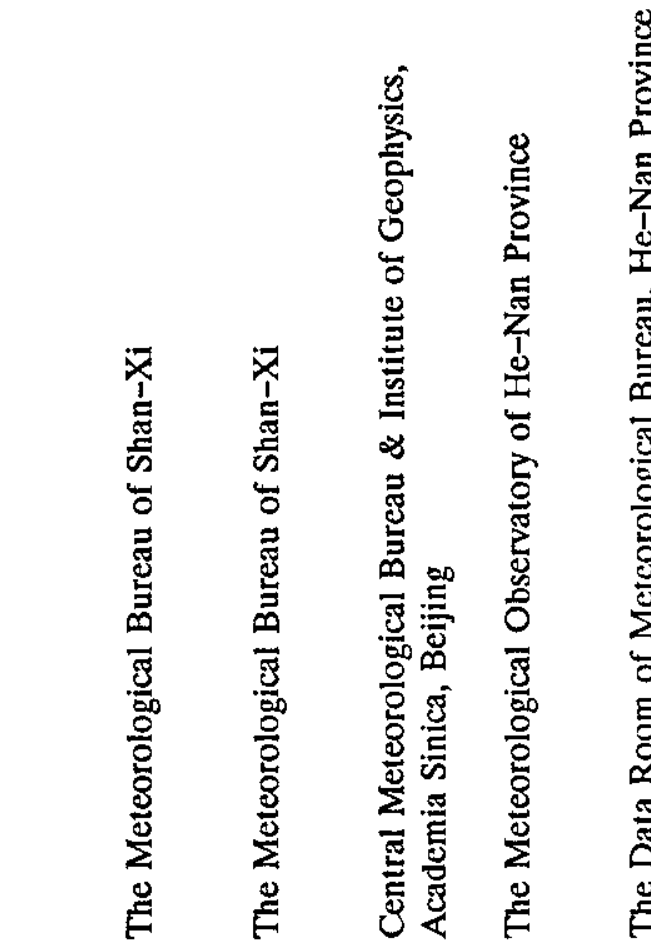

न

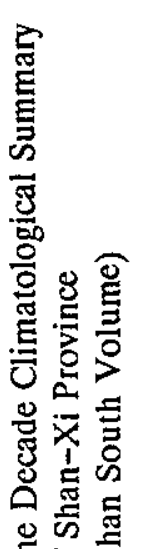

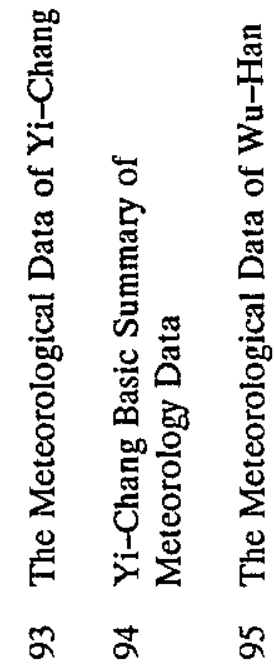




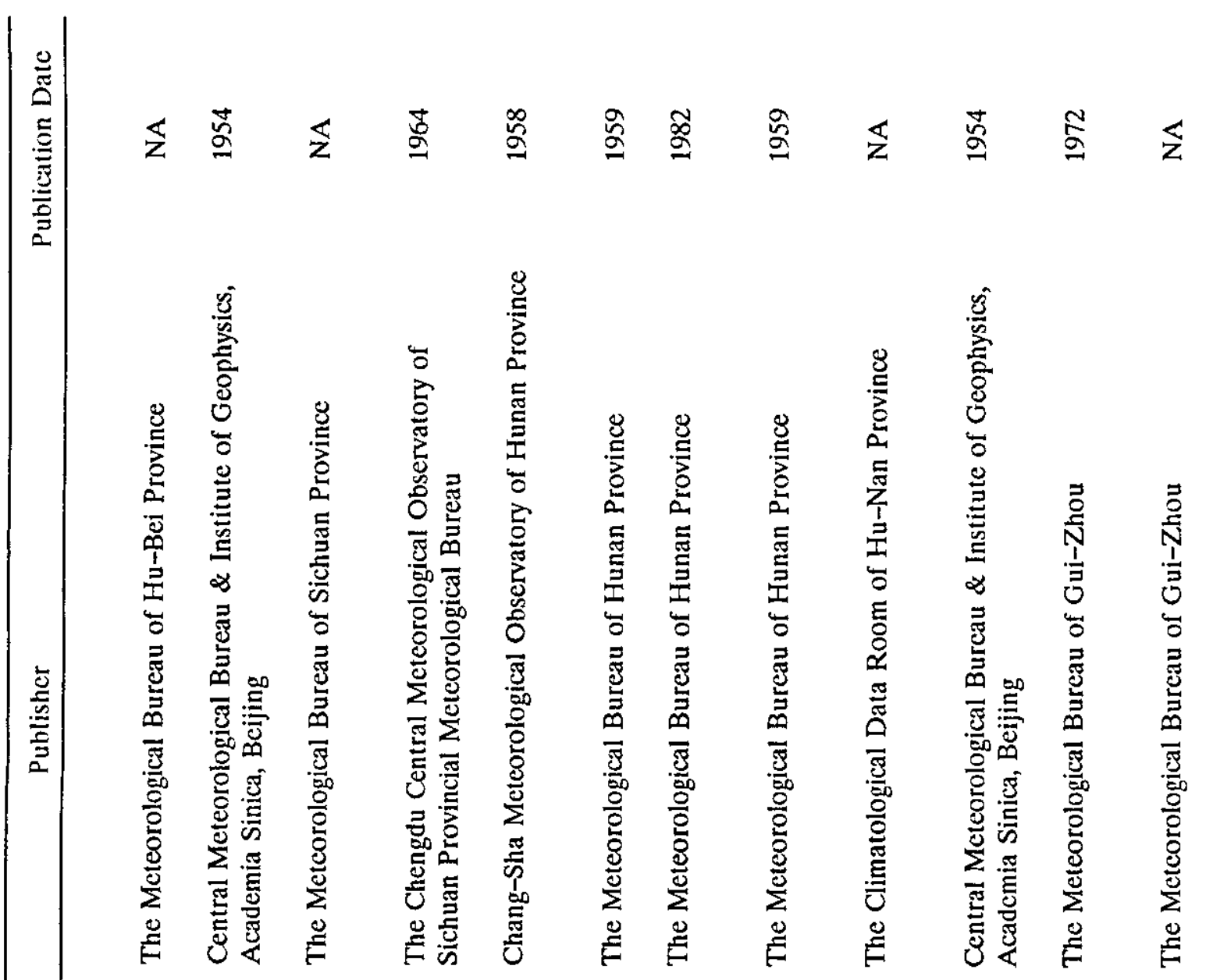

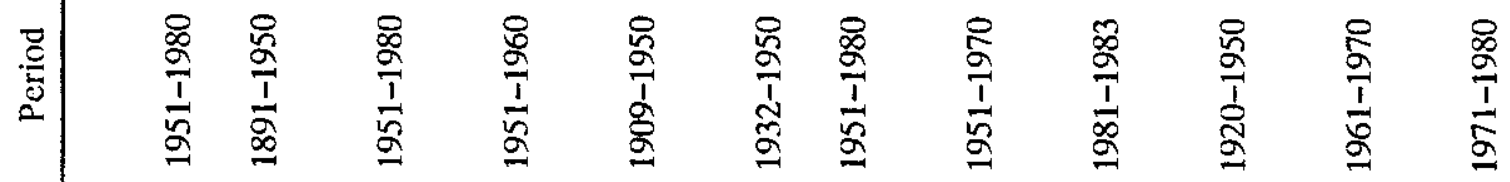

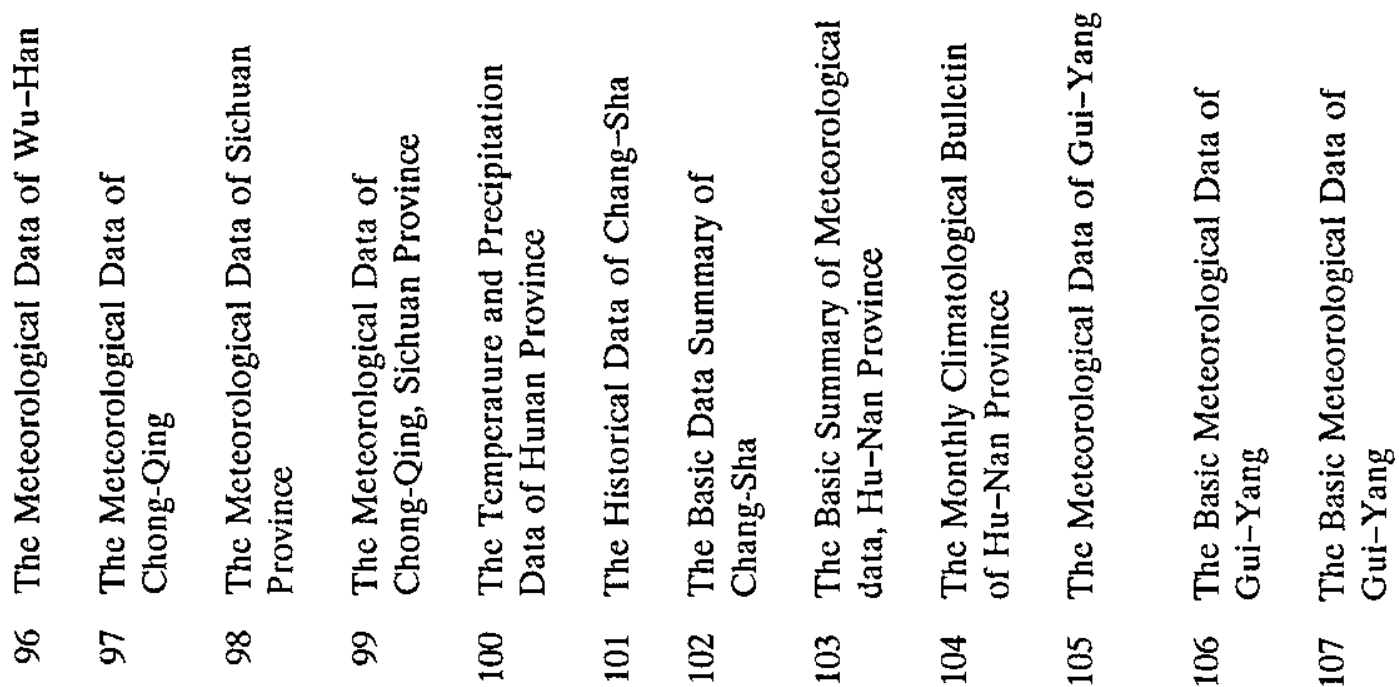




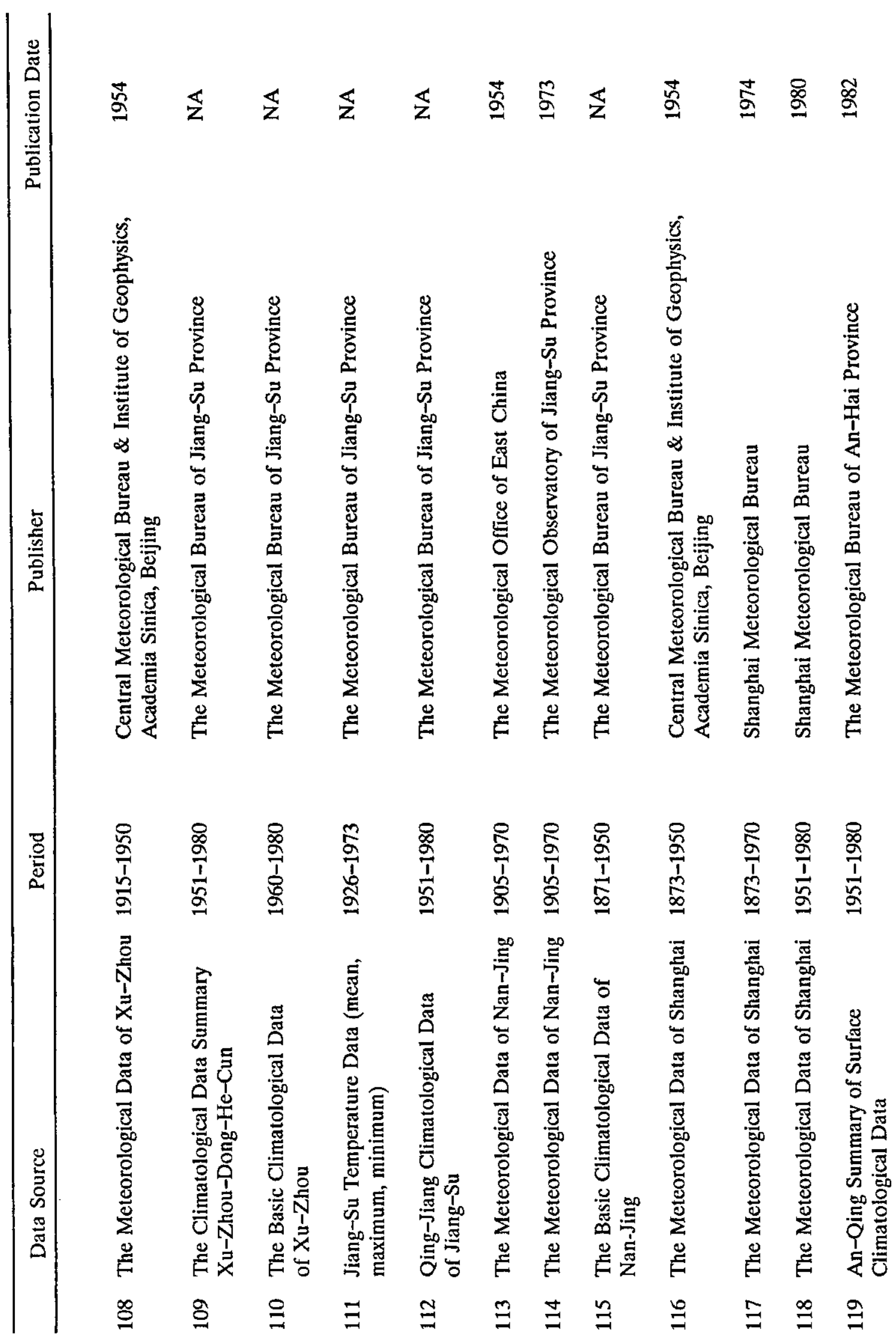




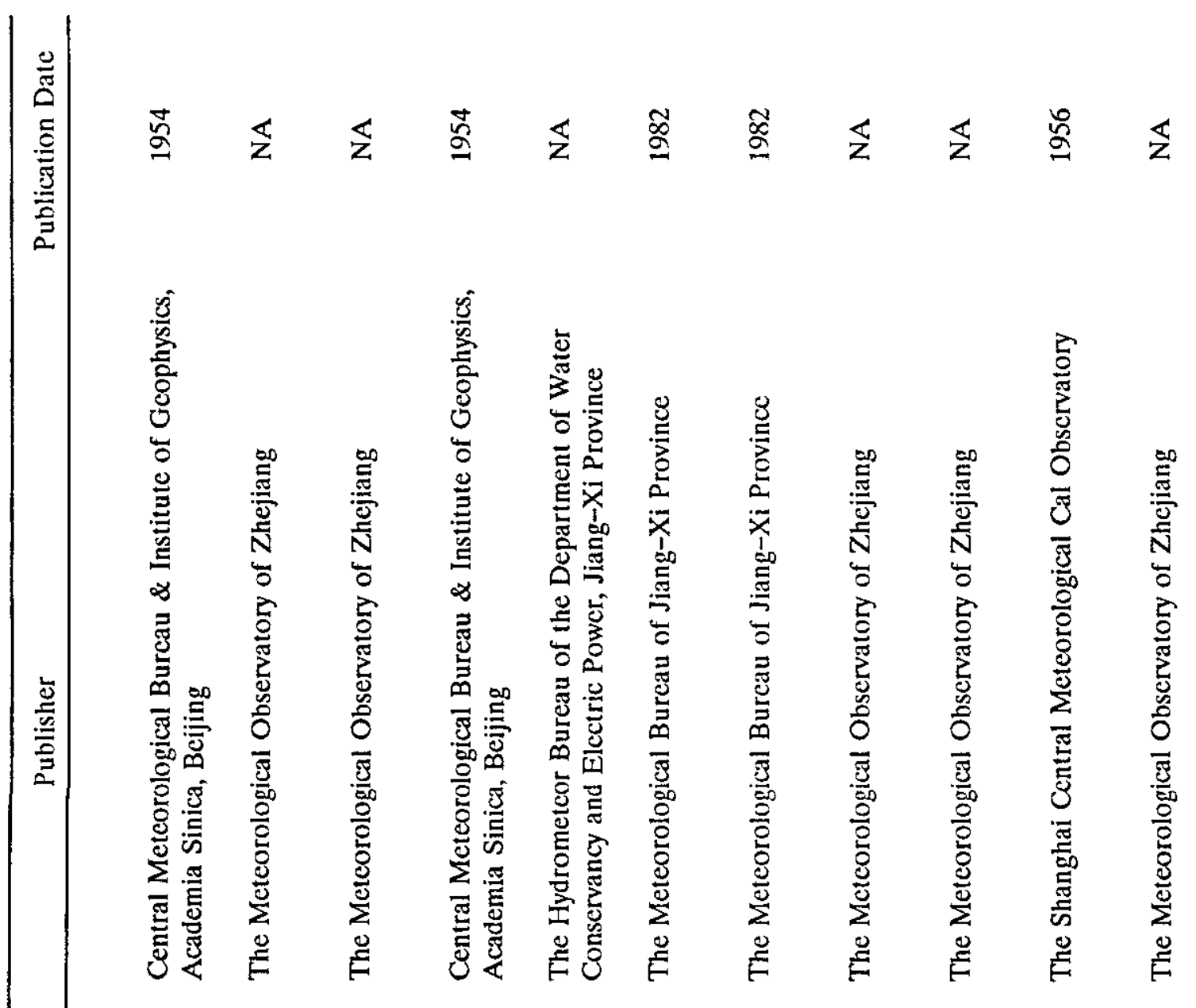

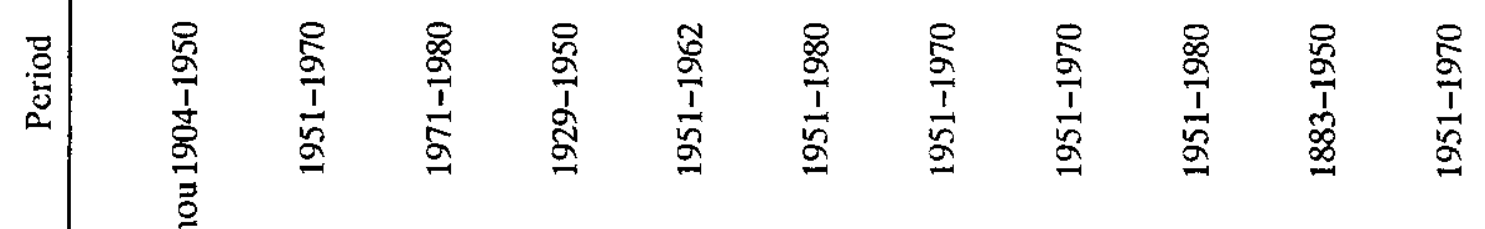

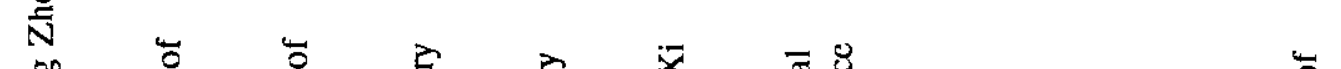

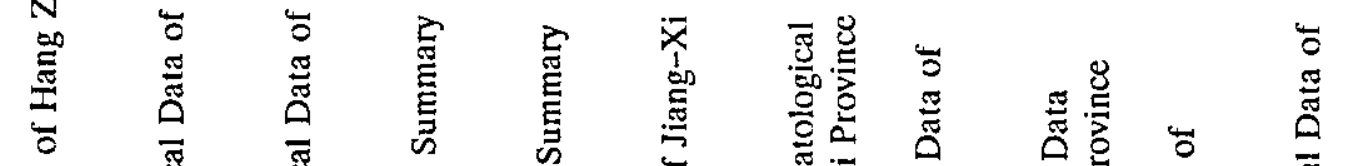

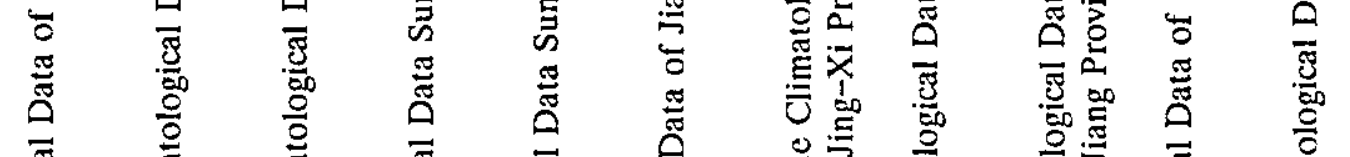

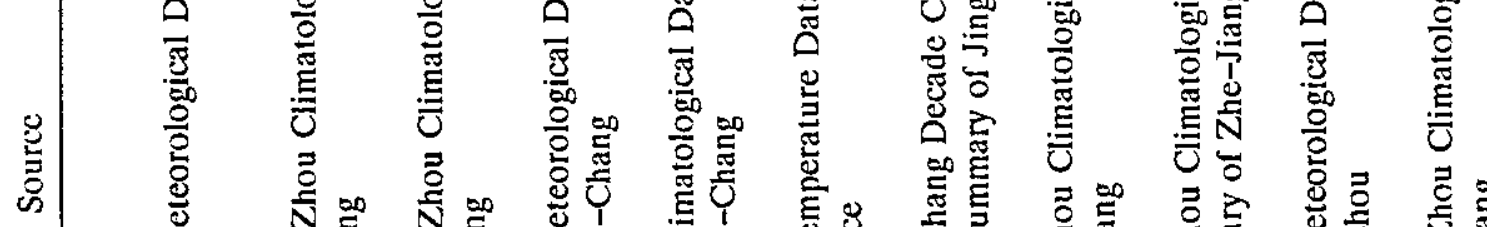

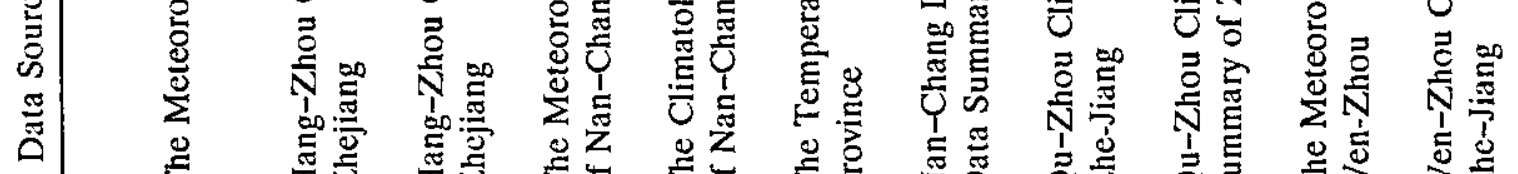

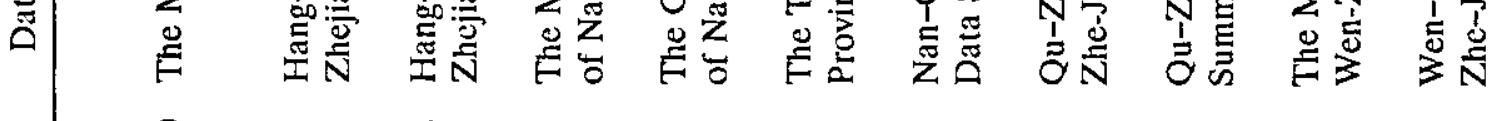

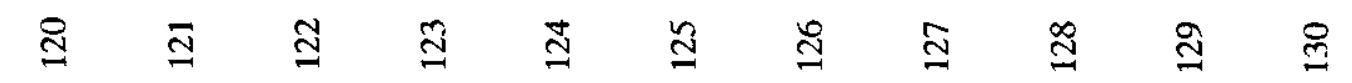




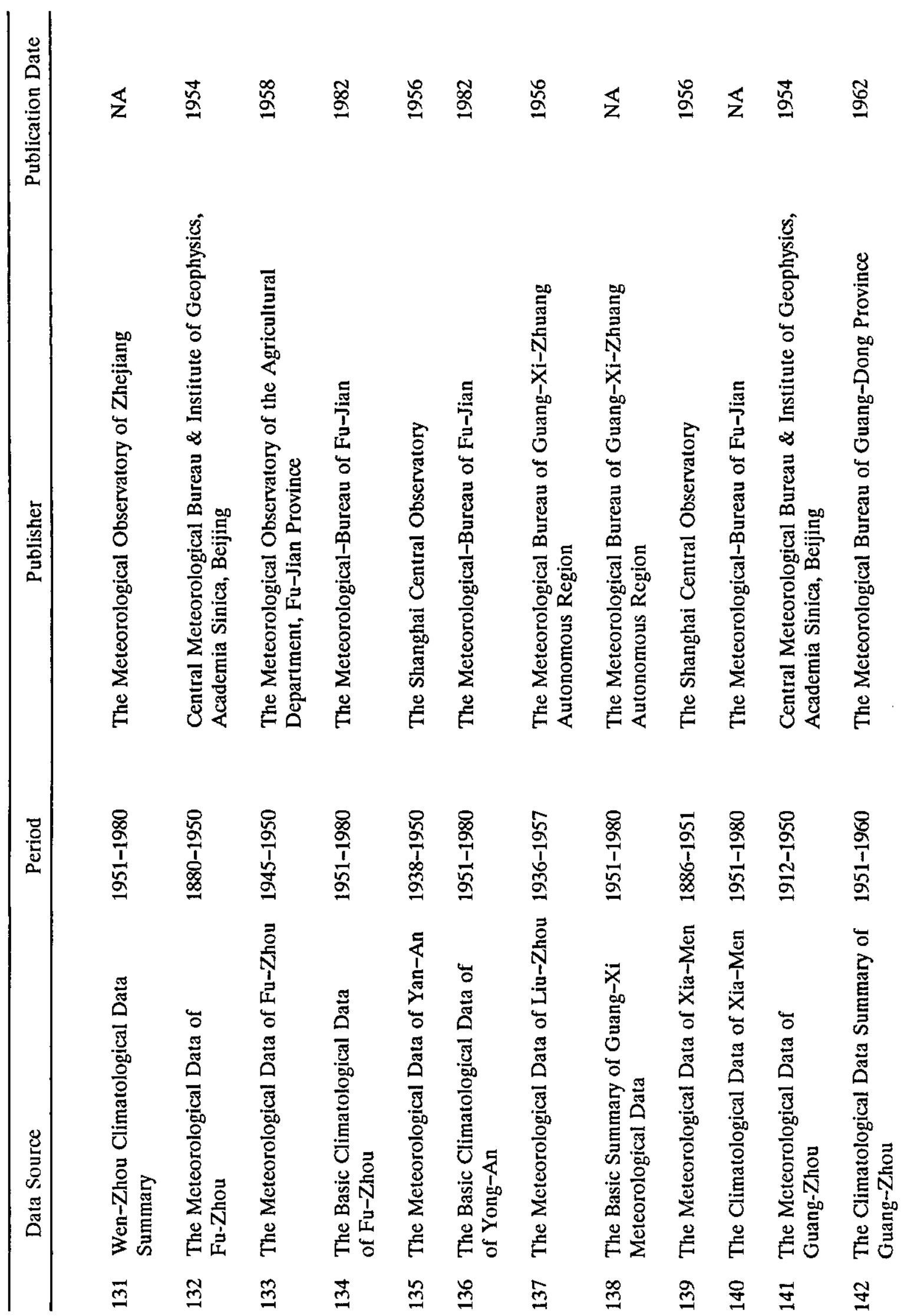




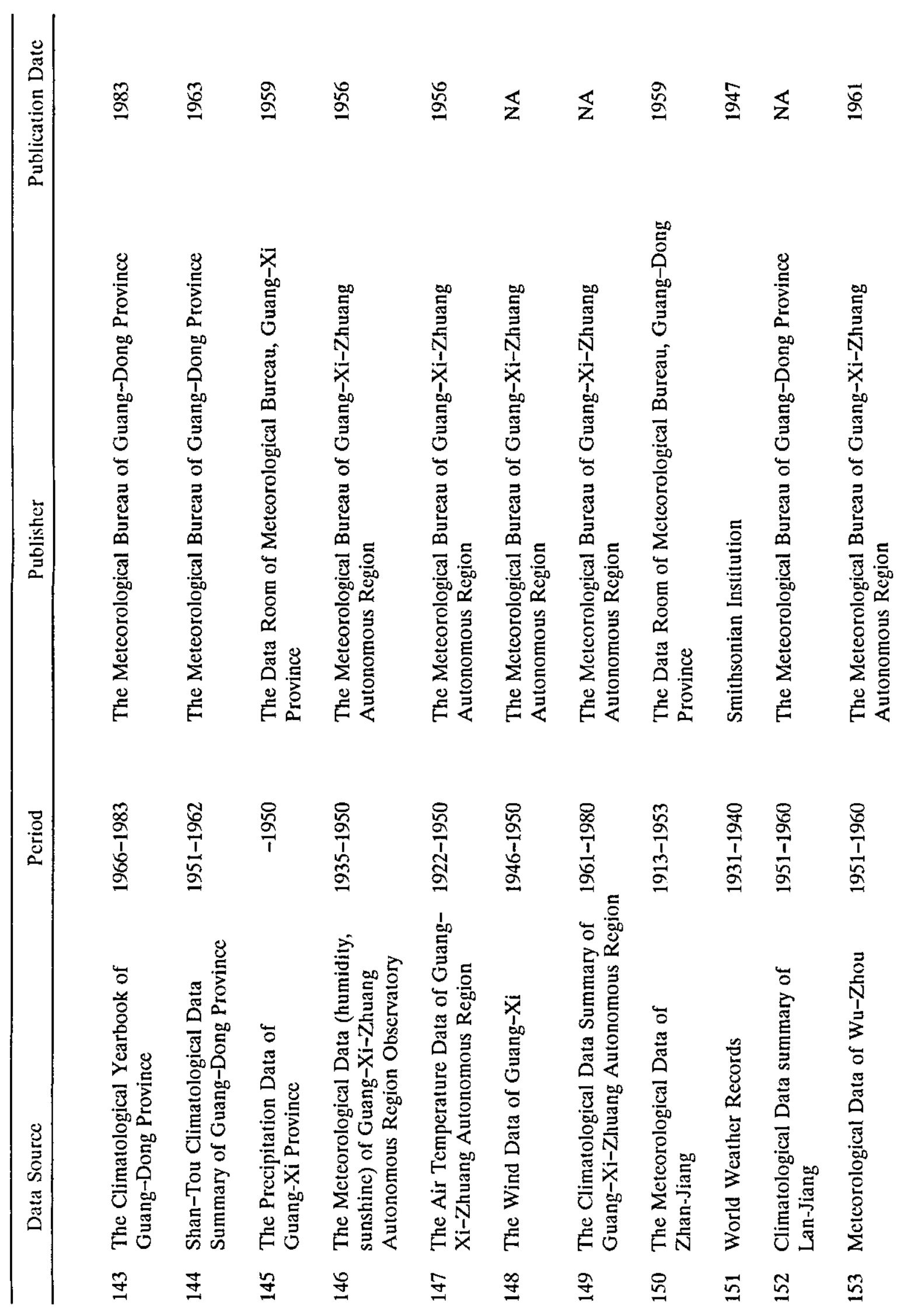


C-17

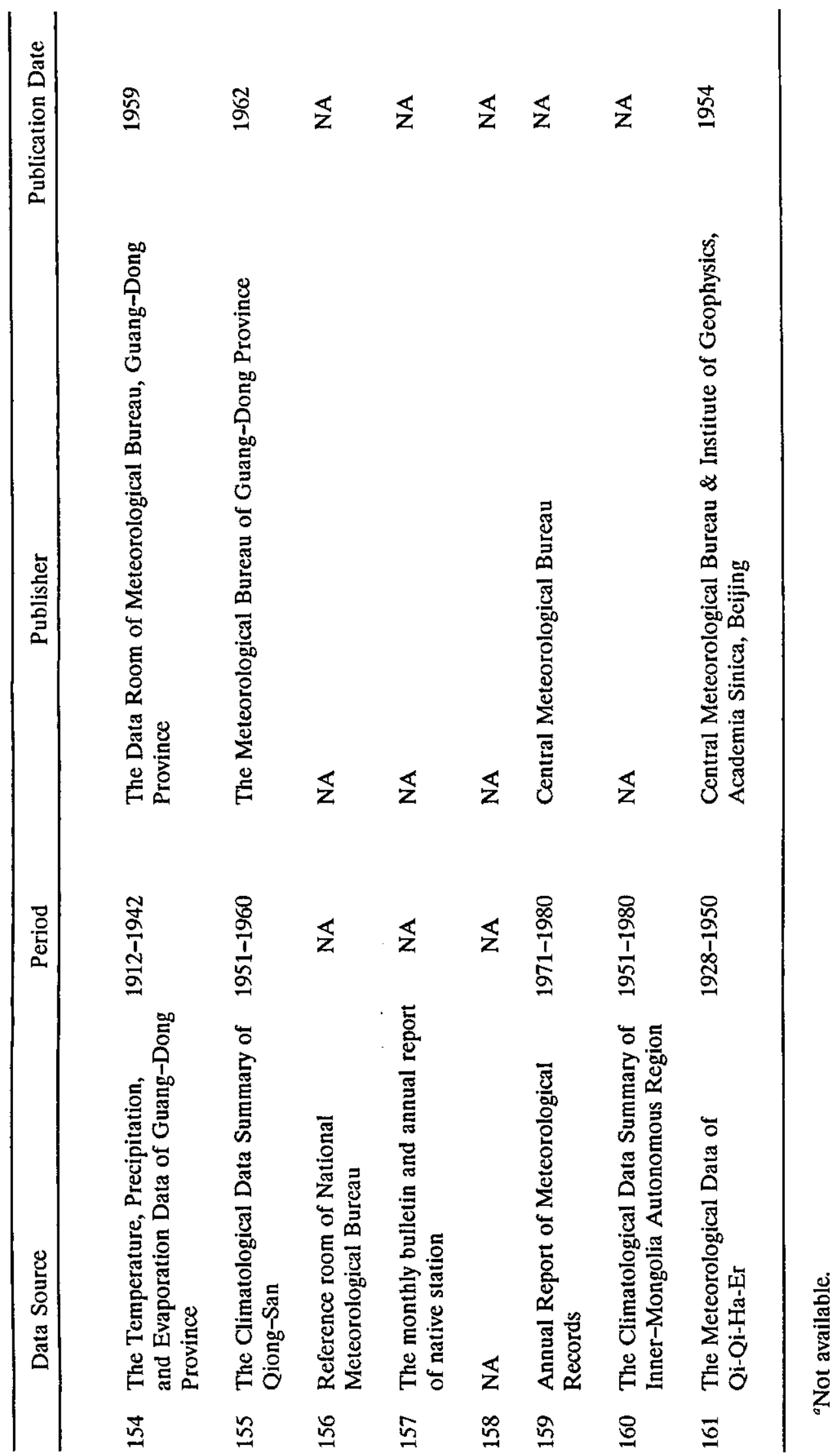





\section{APPENDIX D}

\section{REPRINTS OF PERTINENT LITERATURE}





\title{
URBAN HEAT ISLANDS IN CHINA
}

\author{
Wei-Chyung Wang ${ }^{1}$, Zhaomei Zeng ${ }^{1,2}$, Thomas R. Karl ${ }^{3}$
}

\begin{abstract}
We used 1954-1983 surface temperature from 42 Chinese urban (average population $1.7 * 106$ ) and rural (average population $1.5 * 105$ ) station pairs to study the urban heat island effects. Despite the fact that the rural stations are not true rural stations, the magnitude of the heat islands was calculated to average $0.23^{\circ} \mathrm{C}$ over the thirty-year period with a minimum value during the 1964-1973 decade and maximum during the most recent decade. The urban heat islands were found to have seasonal dependence which varied considerably across the country. The urban heat islands also had a strong regional dependence with the Northern Plains dominating the magnitude of the heat islands. The changes in heat island intensity over three decades studied suggest a general increase in heat island intensity of about $0.1^{\circ} \mathrm{C}$, but this has not been constant in time. These results suggest that caution must be exercised when attributing causes to observed trends when stations are located in the vicinity of metropolitan areas.
\end{abstract}

\section{Introduction}

In recent years concerns were raised about whether the observed increase in atmospheric greenhouse gases was the main cause for the observed increases in the global mean surface temperature of $-0.5^{\circ} \mathrm{C}$ during the last hundred years (see WMO/UNEP, 1990 for a review). These concerns intensified after the 1988 abnormal weather of record high temperature and drought conditions in many regions of the United States and record storms sweeping over Europe. In addition, the 1980's have been documented as the warmest decade on record. Many of these weather anomalies are not inconsistent with the simulations from the general circulation models, which also predict a substantial global warming in the next few decades if the current increasing trends for greenhouse gases continue. A global warming will have serious implications on regional weather and climate with subsequent effects on economic and social activities. Active research has been focused on climate model development to improve regional climate prediction and on observations to detect the greenhouse warming signals (CES, 1989).

One area of the detection issue has focused on the credibility of greenhouse warming attribution in the global temperature trend when many stations are located in the vicinity of major urban areas (Wood, 1988; Karl and Quayle, 1988; Karl et al., 1988; Jones et al., 1990). Regional studies indicate that there exists a significant urban heat island effect in the United States; in some cases it can introduce bias of 0.1-0.3 ${ }^{\circ} \mathrm{C}$ per decade in the temperature trend.

Karl et al. (1988) and Balling and Idso (1989) have studied the relationship between population change and urban warming bias in the United States and the correlations were found to be statistically significant. Karl et al. (1988) have

\footnotetext{
1 Atmospheric Sciences Research Center, State University of New York

2Institute of Atmospheric Physics, Chinese Academy of Sciences, Beijing, China

3National Climatic Data Center, NESDIS/NOAA, Asheville, North Carolina

Copyright 1990 by the American Geophysical Union.

Paper number 90GL02300

$0094-8276 / 90 / 90 \mathrm{GL}-02300 \$ 03.00$
}

developed an empirical relation to correct the urban warming bias in the United States Historical Climate Network (HCN). Even in this mostly rural network of stations, a warm bias of about $0.06^{\circ} \mathrm{C}$ occurs during the twentieth century due to population growth around observing sites.

Both the United States and China are located in midlatitudes with comparable land areas. However, the climates of the two countries are different due to the different topographical and geographic conditions. In addition, there are considerable differences in the non-climatic factors such as the energy consumption, industrialization and population density, which may affect the temperature trends and the magnitude of the urban bias. Consequently, the urban warming bias in China may have a different pattern than that found in the United States.

Several empirical studies have already been conducted to study the urban heat island effects in China (see Zhou and Zhang, 1985 for a review). However, these studies focused on either the big cities such as Shanghai or the comparative study between a big city and the suburbs for one or two selected cities (see Chow, 1986). Here we perform a study of the urban warming bias in the Eastem half of China using many stations. Our work differs from the recent study by Jones et al. (1990). They have shown that any urban bias in their data has been mitigated over Eastem China. The reasons for this are not clear. Our intent is to determine the magnitude and scope of heat islands in China and determine whether there is evidence of any change in their intensity over the past few decades.

\section{Analysis}

The temperature data used in this study are based on 42 pairs of urban-rural stations from a 260 -station temperature data set recently compiled under the United States' Department of Energy and People's Republic of China's Academy of Sciences joint research program on the greenhouse effect (Koomanoff et al., 1988). The temperatures cover the period up to 1983 . For some stations, the data dated back to the nineteenth century, for example, Beijing from 1841 and Shanghai from 1873 .

Data from selected 84 rural and urban stations includes monthly mean temperatures for the period 1954-1983. The period was chosen mainly because most stations were established by 1954 and continuous records exist. We grouped the 42-pairs into six regions: (I) Northeast, (II) Northem Plains, (III) Middle-Lower Changjiang and Huaihe Basin, (IV) Southeast Coast, (V) Southwest and (VI) Northwest; each region had seven station pairs (see Figure 1). Discussion of the geophysical features and climate characteristics of these regions can be found in Domros and Peng (1988). Figure 1 also shows the locations of the station pairs, and the averaged station heights, populations and linear trends over separate urban and rural stations for the individual regions. These stations primarily cover the Eastern part of China. They were chosen based on station histories: selected stations have relatively few, if any, changes in instrumentation, location, or observation times over this period. Additional criteria used to choose the 42-pairs urban-rural stations are: as small as possible spatial distance between the individual pair; most stations with 1985 population of over one million for urban sites (average 1.71 million) and less than 0.2 million for rural sites (average 0.147 million); and suitability of topography, geographical location and the spatial location of the station network. 


\begin{tabular}{|c|c|c|c|c|}
\hline Region & $\begin{array}{l}\text { Urban (U)/ } \\
\text { Rural (R) }\end{array}$ & $\begin{array}{l}\text { Height } \\
\text { (m) }\end{array}$ & $\begin{array}{l}\text { Population } \\
(1000)\end{array}$ & $\begin{array}{l}\text { Linear Trend } \\
\left({ }^{\circ} \mathrm{C} / 30 \text { years }\right)\end{array}$ \\
\hline \multirow[t]{2}{*}{ I } & U & 172 & 1697 & 0.82 \\
\hline & $\mathrm{R}$ & 142 & 241 & 0.51 \\
\hline \multirow[t]{2}{*}{ II } & U & 67 & 2494 & 0.64 \\
\hline & $\mathbf{R}$ & 41 & 89 & 0.35 \\
\hline \multirow[t]{2}{*}{ III } & $\mathrm{U}$ & 47 & 1382 & 0.11 \\
\hline & $\mathbf{R}$ & 45 & 188 & 0.21 \\
\hline \multirow[t]{2}{*}{ IV } & $\mathrm{U}$ & 31 & 2025 & 0.10 \\
\hline & $\mathbf{R}$ & 29 & 59 & 0.05 \\
\hline \multirow[t]{2}{*}{ v } & $\mathrm{U}$ & 726 & 1490 & -0.21 \\
\hline & $\mathbf{R}$ & 647 & 162 & -0.14 \\
\hline \multirow[t]{2}{*}{ VI } & $\mathrm{U}$ & 1143 & 1212 & 0.70 \\
\hline & $\mathbf{R}$ & 1073 & 144 & 0.44 \\
\hline \multicolumn{5}{|l|}{ China } \\
\hline & $\mathrm{U}$ & 363 & 1717 & 0.36 \\
\hline & $\mathbf{R}$ & 330 & 147 & 0.24 \\
\hline
\end{tabular}

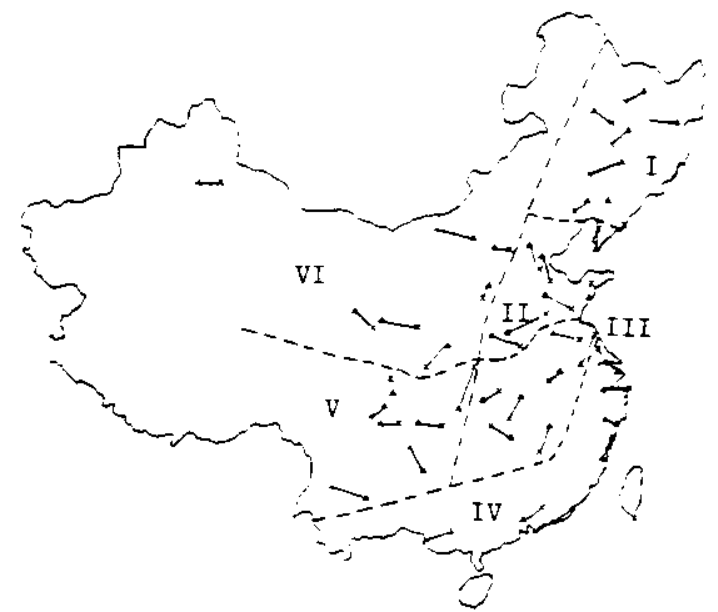

Fig.1: The 42-pairs urban (in $\Delta$ ) and rural (in $\mathrm{X}$ ) stations used to study the urban heat islands. The values of station heights, populations, and 30-year linear trends averaged over the separate urban and rural stations are calculated for six regions: (I Northeast, (II) Northern Plains, (III) Middle-Lower Changiiang and Huaihe Basin, (IV) Southeast Coast, (V) Southwest, and (VI) Northwest. Note that the population statistics used are 1981 - 1985 averages for urban stations and $1984-1985$ averages for rural stations.

We first examined the spatial pattem of the temperature trends for the individual stations and the results of the regional average are included in Figure 1. In general, the regions of the Northeast, and Northern Plains and Northwest showed large positive trends for both the urban and rural stations while negative trends were observed in the Southwest. Note that these results imply a tendency for a decrease in the north-south temperature gradient. The thirty-year trends averaged over the Eastern half of China were $0.36^{\circ} \mathrm{C}$ for the urban stations and $0.24^{\circ} \mathrm{C}$ for the rural stations.

Figure 2 shows the 1954-1983 annual mean temperatures averaged over the 42 urban and rural stations separately. In general, three stages are observed for both the urban and rural temperatures: a warming trend before 1961; a cooling trend between 1961-1969; and a warming trend after 1969. The temperatures averaged over the thirty years for nural and urban stations are calculated to be $12.61^{\circ} \mathrm{C}$ and $12.80^{\circ} \mathrm{C}$, respectively.

These urban-rural temperature differences however, include factors such as differences in geography and topography, which will have influences on the temperature differences. To minimize the effect of topography and geography, we used multiple regression techniques. The differences in altiude, latitude and longitude between the paired urban and rural stations were used to predict the urban-rural temperature difference. The residuals between these

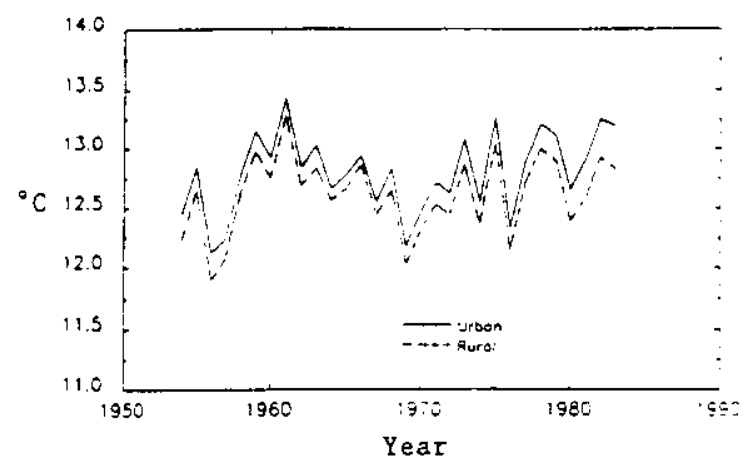

Fig. 2: The annual mean temperatures averaged over the urban and nural stations shown in Figure 1. The mean temperatures for rural and urban stations averaged over $1954-1983$ are $12.61^{\circ} \mathrm{C}$ and $12.80^{\circ} \mathrm{C}$, respectively. predictions and the actual urban-rural temperature differences were used to refine the urban-rural differences. The differences are referred to as "corrected" differences. Using the F-test, we find that the regressions are statistically significant at the 0.01 significance level for the annual averages and at the 0.05 level for the seasonal averages.

The corrected annual and seasonal urban heat islands are given in Table 1 . The results indicate that temperatures averaged $0.23^{\circ} \mathrm{C}$ warmer in the urban areas across all regions and seasons (as opposed to $0.19^{\circ} \mathrm{C}$ for the uncorrected urbanrural difference). Averaged across all of China, the strongest urban heat islands, $0.29^{\circ} \mathrm{C}$, occurred in winter and the weakest, $0.14^{\circ} \mathrm{C}$, in summer. Considerable variability exists from region to region however, and a portion of this variability is unlikely to be related to heat island effects. For example, if we omit the Northern Plains which has a very large difference between summer and winter, then the results are similar to those observed in the United States: stronger heat islands occur in summer compared to winter (Table 1). As such, the summer to winter differences may not be significant. Further study of the characteristics in the region of Northern Plains, including the data quality, is warranted. The Middle-Lower Changiang and Huaihe Basin and the Northwest also showed a large annual urban heat islands (about $0.35^{\circ} \mathrm{C}$ ), but the seasonal variation is relatively small; in fact, these two regions together with the Northem Plains dominate the annual average urban-rural temperature difference of $0.23^{\circ} \mathrm{C}$ for all of China. The urban-rural temperature differences in other areas were small. The large difference between regions suggests that more data would be desirable to determine whether the regional differences are sampling enors or real physical characteristics.

The interannual variability of the annual and seasonal mean urban-rural temperatures is shown in Figure 3. This is of particular interest with respect to potential urban heat island biases in long-term temperature series derived from urban stations in China. For the annual-mean case (Figure 3a), the changes in the urban-rural temperature difference had two stages, a decreasing trend before 1966 and an increasing trend afterwards. The magnitude of the increase is particularly large after 1977. These trends may be associated with energy consumption and population movement resulting from economic and political activities during the periods of the Great Leap Forward before 1966 and the Cultural Revolution afterward. During those periods, many factories were closed and production halted through a reduction of the staff. Since 1972 , industry functions gradually retumed to normal and after 
D-5

Wang et al.: Urban Heat Islands in China

Table 1. Annual and seasonal urban heat islands $\left({ }^{\circ} \mathrm{C}\right)$ in China averaged over the period 1954-1983

\begin{tabular}{lccccc}
\hline Region & Spring & Summer & Autumn & Winter & Annual \\
\hline Northeast & 0.18 & 0.03 & -0.09 & 0.06 & 0.04 \\
Northem Plains & 0.20 & -0.18 & 1.07 & 1.42 & 0.63 \\
Middle-Lower & 0.44 & 0.42 & 0.38 & 0.21 & 0.36 \\
$\quad \begin{array}{c}\text { Changjiang and } \\
\text { Huaihe Basin }\end{array}$ & & & & & \\
Southeast Coast & -0.13 & 0.20 & 0.03 & -0.08 & 0.01 \\
Southwest & 0.24 & 0.04 & -0.05 & -0.22 & 0.00 \\
Northwest & 0.32 & 0.35 & 0.36 & 0.35 & $0.35^{*}$ \\
China-Mean & 0.21 & 0.14 & 0.28 & 0.29 & 0.23 \\
& $(0.21)^{\dagger}$ & $(0.21)$ & $(0.13)$ & $(0.06)$ & $(0.15)$ \\
& & 0.22 & 0.44 & 0.59 & 0.26 \\
\multicolumn{1}{c}{ Standard } & 0.19 & $(0.17)$ & $(0.22)$ & $(0.22)$ & $(0.18)$ \\
\hline
\end{tabular}

* The annual value is $0.28^{\circ} \mathrm{C}$ if the Hohhot-Urad Zhongqi pair in the far west is excluded (see Figure 1); this will have a small effect on the annual mean over China, reducing to 0.22 ${ }^{\circ} \mathrm{C} . \uparrow$ Values in the parentheses are the averages without including the Northem Plains.
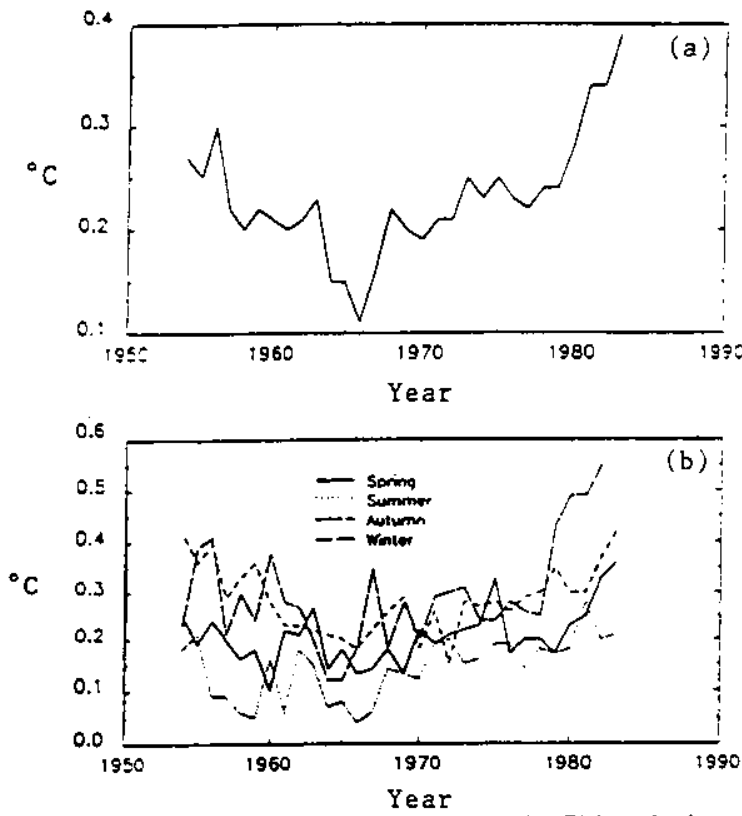

Fig. 3: Urban-rural temperature difference in China during 1954-1983 for (a) annual mean and (b) seasonal mean values.

1978, factory production and economic development rapidly expanded under the new Open Door policy. As a result, a large inflow of rural population to the cities occurred so that the urban heat islands in China may have increased as a result.
This is evident beginning the year 1977 in Figure 3a. Much more detailed analyses of the attributes are needed however, before we can be certain of the causes for such trends.

On a seasonal basis (Figure 3b), similar features are also observed. It is quite clear that, for all four seasons, the magnitudes of the urban heat island bias after 1966 has been increasing. The trend is particularly strong during autumn and winter. Before 1966, except for autumn and winter, the urbanrural temperature differences showed little trend.

The annual and seasonal urban heat-island bias during the three ten-year periods are summarized in Table 2 . The values reflect the heat island features discussed above: maximum during winter and minimum during summer for the average of all regions, but just the opposite when the Northern Plains is omitted from the sample. Increased heat islands occur during the most recent decade for all of Eastern China with and without the Northern Plains. We have also examined the urban heat island bias for the three ten-year periods on the regional basis, shown in Table 3 . The general characteristics are similar to the annual features observed in Table 2. However, the decadal changes in urban-rural temperature differences are large in Northeast, Northern Plains, Southeast Coast, and the Northwest while the other two regions showed small changes. Because of the lack of population statistics in China, in the analysis of the relation between population and heat island effects we used the available population data during 1981-1985 for the cities and 1984-1985 for the rural stations. The population difference versus the temperature difference for the individual urban-rural pairs were used to derive an empirical correlation. The relationship exists. However, the correlation is not statistically significant, which suggests that we would problably need many more station pairs before we could

Table 2. Annual and seasonal urban heat islands $\left({ }^{\circ} \mathrm{C}\right)$ in China

\begin{tabular}{rccccc}
\hline Period & Spring & Summer & Autumn & Winter & Annual \\
\hline $1954-63$ & 0.20 & 0.12 & 0.31 & 0.29 & 0.23 \\
& $(0.21)^{*}$ & $(0.19)$ & $(0.18)$ & $(0.06)$ & $(0.16)$ \\
$1964-73$ & 0.17 & 0.12 & 0.22 & 0.23 & 0.19 \\
& $(0.19)$ & $(0.18)$ & $(0.06)$ & $(0.01)$ & $(0.11)$ \\
$1974-83$ & 0.25 & 0.19 & 0.31 & 0.36 & 0.28 \\
& $(0.23)$ & $(0.25)$ & $(0.16)$ & $(0.13)$ & $(0.19)$ \\
\hline
\end{tabular}

*Values in the parentheses are the averages without including the Northern Plains. 
Table 3. Annual urban heat islands $\left({ }^{\circ} \mathrm{C}\right)$ in China

\begin{tabular}{lcccc}
\hline Region & $1954-63$ & $1964-73$ & $1974-83$ & $1954-83$ \\
\hline Northeast & 0.00 & -0.03 & 0.16 & 0.04 \\
Northern Plains & 0.62 & 0.57 & 0.70 & 0.63 \\
Middle-Lower & 0.41 & 0.34 & 0.34 & 0.36 \\
$\quad$ Changiang and & & & & \\
$\quad$ Huaihe Basin & 0.00 & -0.05 & 0.06 & 0.01 \\
Southeast Coast & 0.01 & 0.01 & -0.01 & 0.00 \\
Southwest & 0.35 & 0.28 & 0.42 & 0.35 \\
Northwest & & 0.19 & 0.28 & 0.23 \\
China & 0.23 & 0.19 & \\
\hline
\end{tabular}

predict the magnitude of the urban heat islands on an annual basis.

\section{Conclusions and Discussion}

We used the 1954-1983 surface temperature data in Eastern China to examine the urban heat island effects. The average effect was calculated to be quite substantial in our data, about $0.23^{\circ} \mathrm{C}$ for the last thirty years. The heat island effects also had strong seasonal and regional dependences with considerable variability.

Our focus in the present study has been mainly on the urban-rural temperature difference so that the choice of the station network was surictly based on the station pairs and their homogeneous distribution. Consequently, our rural stations are generally not the true "rural" stations; rather they are cities with fairly large populations (see Figure 1). Our results suggest that in the absence of other factors which could cancel the urban heat island bias, stations in China located in the vicinity of major cities have relatively large heat islands. The changes in the magnitude of the urban-rural temperature differences over the $1954-83$ period indicate that since the late 1970 's the rate of warming at urban stations is over $0.1^{\circ} \mathrm{C}$ per decade relative to more rural stations. Although there has been rapid urbanization in China since the 1970's, it is not certain whether the trend from such a shor period should be atributed solely to urbanization. An updated data set may clarify this situation. These results suggest that caution must be used when using trends from stations in the vicinity of major metropolitan areas.

Acknowledgments. Zhaomei Zeng participated in the study as a visiting scholar under the United States Department of Energy and the People's Republic of China's Academy of Sciences Joint Research on the Greenhouse Effect. This research was supported by the Atmospheric and Climate Division, Office of Health and Environmental Sciences, Department of Energy.

\section{References}

Balling, R. C., Jr. and S. B. Idso, Historical temperature trends in the United States and the effect of urban population growth, L. Geophys. Res. 94, 3359-3363, 1989.

CES, Our changing planet: the FY 1990 research plan, a report by the Committee on Earth Sciences, Washington D.C., 1989.
Chow, S. D., Some aspects of the urban climate of Shanghai, Proceedings of the Technical Conference: Urban Climatology and its Applications with Special Regard to Tropical Areas, edited by T. R. Oke, World Meteorological Organization, No. 652, 87-109, 1986.

Domros, M, and G. Peng, The Climate of China, 360 pp., Springer-Verlag, Berlin-Heidelberg-New York-LondonParis-Tokyo, 1988.

Jones, P. D., P. Ya Groisman, M. Coughlan, N. Plummer, W.-C. Wang and T. R. Karl, How large is the urbanization bias in large-area-averaged surface air temperature trends?, Nature, 347, 169-172, 1990.

Kari, T. R. and R. G. Quayle, Climatic change in fact and theory: Are we collecting the facts?, Climatic Change. 13, 5-17, 1988.

Karl, T. R., H. Diaz, and G. Kukla, Urbanization: Its detection in the U. S. climate record, J.Clim. 1 1099-1123, 1988.

Koomanoff, F., T. Ye, M. R. Riches, C. Zhao, W.-C. Wang, and S. Tao, U.S. Department of Energy and P. R. C. Chinese Academy of Sciences Joint Research on Greenhouse Effect, Bull Amer. Meteor. Soc. 61, 1301 $1308,1988$.

Wood, F. B., Comment: on the need for validation of the Jones et al. temperature trends with respect to urban warming, Climatic Change.12, pp. 297-312, 1988.

World Meteorological Organization/United Nations Environmental Programme, An intergovemmental panel on climate change working group 1 report, scientific assessment of climate change, 1990.

Zhou, S. Z. and C. Zhang, (Eds.), Urban heat islands, Lirban Climate Section 5, pp. 85-132 (in Chinese), 1985.

T. R. Karl, National Climatic Data Center/NOAA, Battery Park and Page Street, Asheville, NC 28801

W.-C. Wang, Aumospheric Sciences Research

Center/SUNY, 100 Fuller Road, Albany, NY 12205.

Zhaomei Zeng, Institute of Atmospheric Physics, Chinese Academy of Sciences, Beijing, China

\footnotetext{
(Received August 24, 1990; revised October 12, 1990; accepted October 15, 1990)
} 


\section{INTERNAL DISTRIBUTION}

1. T. A. Boden

2. J. H. Cushman

3. R. M. Cushman

4. M. P. Farrell

5. D. E. Fowler

6. C. W. Gehrs

7. S. G. Hildebrand

8. D. P. Kaiser

9. P. Kanciruk

10. D. E. Reichle

11. D. S. Shriner

12. S. H. Stow

13. R. I. Van Hook

14-113. CDIAC

114. Central Research Library

115-118. ESD Library

119. Information Analysis Library

120-121. Laboratory Records Department

122. Laboratory Records, RC

123. ORNL Patent Office

124. ORNL Y-12 Technical Library

\section{EXTERNAL DISTRIBUTION}

125. Roger C. Dahlman, Carbon Dioxide Research Program, Environmental Sciences Division, Office of Health and Environmental Research, ER-74, U.S. Department of Energy, Washington, DC 20585

126. David Easterling, National Climatic Data Center, Federal Building, Asheville, NC 28801

127. Jerry F. Franklin, Bloedel Professor of Ecosystem Analysis, College of Forest Resources, University of Washington, Anderson Hall (AR-10), Seattle, WA 98195

128-132. Fu Congbin, Institute of Atmospheric Physics, Chinese Academy of Sciences, Beijing, China

133. David J. Galas, Office of Health and Environmental Research, ER-70, U.S. Department of Energy, Washington, DC 20585 
134. Thomas J. Gross, Carbon Dioxide Research Program, Environmental Sciences Division, Office of Health and Environmental Research, ER-74, U.S. Department of Energy, Washington, DC 20585

135. Sultan Hameed, Laboratory for Planetary Atmospheres Research, State University of New York, Stony Brook, NY 11794-2300

136. George M. Hornberger, Department of Environmental Sciences, Clark Hall, University of Virginia, Charlottesville, VA 22903

137. Pamela Hughes, National Climatic Data Center, Federal Building, Asheville, NC 28801

138. Roy L. Jenne, National Center for Atmospheric Research, P.O. Box 3000, Boulder, CO $80307-3000$

139. G. Y. Jordy, Director, Office of Program Analysis, Office of Energy Research, ER-30, G-226, U.S. Department of Energy, Washington, DC 20585

140. Thomas R. Karl, National Climatic Data Center, Federal Building, Asheville, NC 28801

141. F. A. Koomanoff, Office of Basic Energy Sciences, ER-10, U.S. Department of Energy, Washington, DC 20585

142. T. K. Lau, Program Officer, Office of International Affairs, IE-12, U.S. Department of Energy, Forrestal Building, Washington, DC 20585

143. H. M. McCammon, Acting Deputy Director, Environmental Sciences Division, Office of Health and Environmental Research, Office of Energy Research, ER-74, U.S. Department of Energy, Washington, DC 20585

144. R. H. Olsen, Vice President for Research, University of Michigan, Medical Science Building II, \#5605, 1301 East Catherine Street, Ann Arbor, MI 48109-0620

145. Ari Patrinos, Acting Director, Environmental Sciences Division, Office of Health and Environmental Research, ER-74, U.S. Department of Energy, Washington, DC 20585

146. David Portman, Atmospheric and Environmental Research, Incorporated, 840 Memorial Drive, Cambridge, MA 02139

147. Michael R. Riches, Carbon Dioxide Research Program, Environmental Sciences Division, Office of Health and Environmental Research, ER-74, U.S. Department of Energy, Washington, DC 20585

148. Peter M. Steurer, National Climatic Data Center, Federal Building, Asheville, NC 28801 
149-153. Tao Shiyan, Institute of Atmospheric Physics, Chinese Academy of Sciences, Beijing, China

154-156. Wei-Chyung Wang, Professor and Head, Climate System Sciences, Atmospheric Sciences Research Center, University of Albany, State University of New York, 100 Fuller Road, Albany, NY 12205

157. F. J. Wobber, Environmental Sciences Division, Office of Health and Environmental Research, Office of Energy Research, ER-74, U.S. Department of Energy, Washington, DC 20585

158-162. Zeng Zhaomei, Institute of Atmospheric Physics, Chinese Academy of Sciences, Beijing, China

163-167. Zhang Qingyun, Institute of Atmospheric Physics, Chinese Academy of Sciences, Beijing, China

168. Office of Assistant Manager for Energy Research and Development, Oak Ridge Operations, P. O. Box 2001, U.S. Department of Energy, Oak Ridge, TN 37831-8600

169-178. Office of Scientific and Technical Information, P. O. Box 62, Oak Ridge, TN 37831 
